UNIVERSIDADE DE SÃO PAULO

INSTTTUTO DE QUÍMICA

\title{
CARACTERIZAÇÃO DE DOIS GENES CONTÍGUOS DE TRYPANOSOMA CRUZI QUE CODIFICAM ANTÍGENOS COM REPETIÇÕES DE EPITOPOS IMUNODOMINANTES
}

\section{ARTHUR GRUBER}

Tese de Doutoramento apresentada ao Departamento de Bioquímica do Instituto de Química da Universidade de São Paulo.

Orientadora: Profa. Dra. Bianca Zingales

SÃO PAULO 


\section{ARTHUR GRUBER}

Tese de Doutorado submetida do Instituto de Química da Universidade de São Paulo como parte dos requisitos necessários à obtenção do grau de Doutor em Ciências - Área: Bioquímica.

Aprovada por:
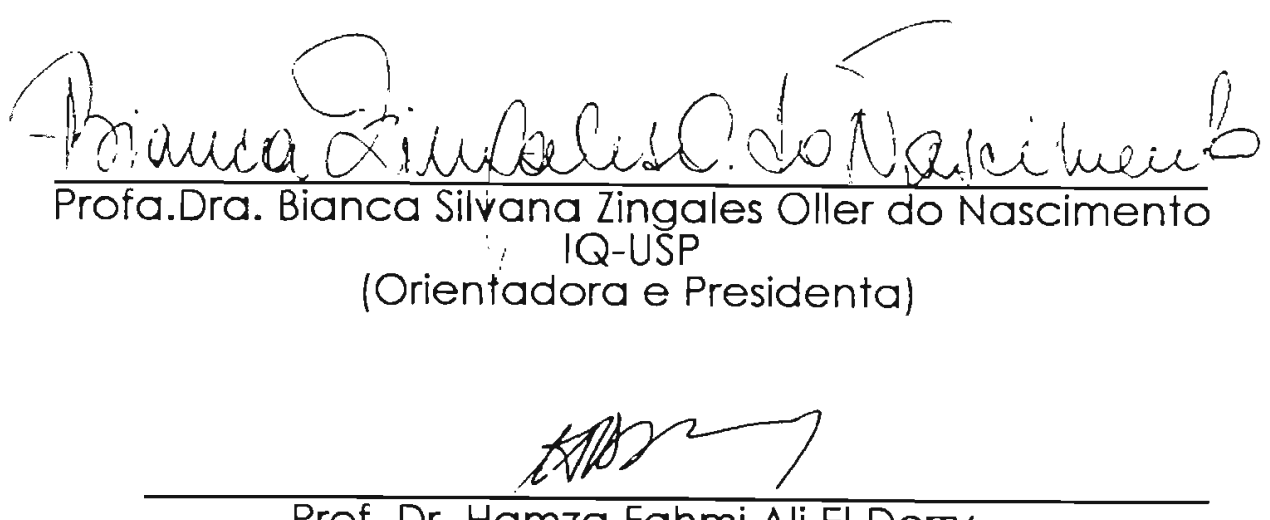

Prof. Dr. Hamza Fahmi Ali El Dorry

IQ-USP

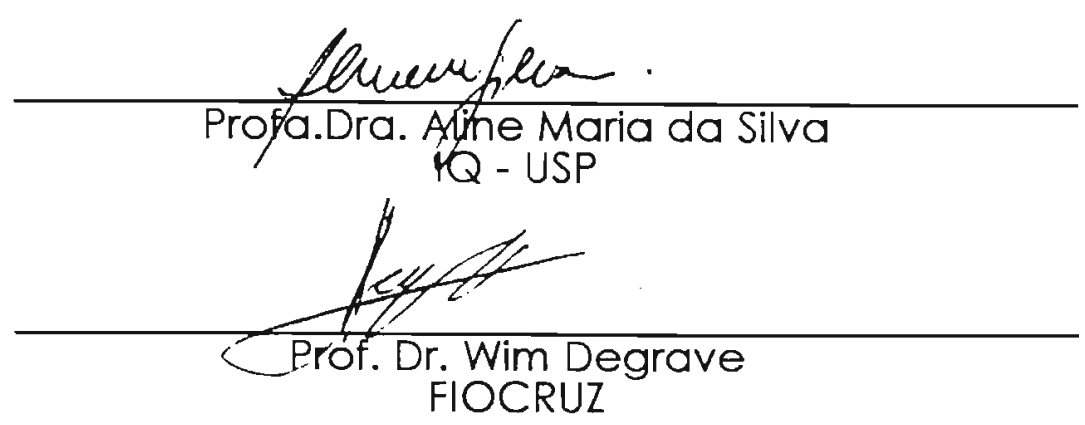

FIOCRUZ

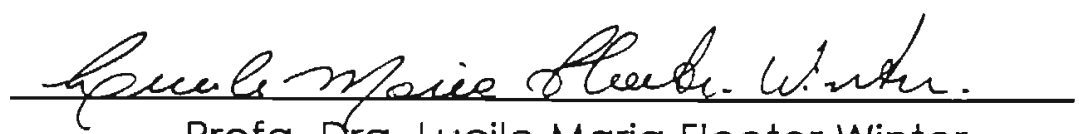

Profa. Dra. Lucile Maria Floeter Winter

ICB II-USP 
Aos meus amados pais que, na sua incansável luta, tornaram possível esta realização. A eles tudo devo, pois deles tudo recebi.

Ao meu irmão pelo exemplo e pelo apoio que sempre me ofereceu. 
À Fernanda, minha companheira adorável, causa maior da felicidade e alegria que sinto neste momento. 


\section{AGRADECIMENTOS}

A Bianca Zingales, pelo esforço e entusiasmo que sempre dedicou na orientação deste trabalho. Esta orientação foi essencial no meu processo de formação cientifica e, aliada à liberdade e ao incentivo que sempre me ofereceu, permitiu que eu pudesse me aprimorar dentro e fora do laboratório.

A Walter Colli, pelo exemplo que me ofereceu de conduta cientifica e de respeito à liberdade de opiniões. A sua capacidade de enxergar muito além do presente é uma das qualidades que certamente influíram muito em minha formação.

A Maria Júlia Manso Alves e Robert Ivan Schumacher, que sempre estiveram dispostos a me ajudar e com quem sempre tive um ótimo relacionamento.

A Marinei Ferreira Gonçalves que, muito além de um simples relacionamento profissional, foi uma pessoa humana e amiga com quem sempre pude contar nos bons e maus momentos. Sua ajuda foi imprescindível para a realização deste trabalho.

Aos técnicos Cecilia França Lopes, Lucinda Cândida da Silveira e Roberto Zangrandi. A maior abnegação não é trabalhar arduamente para obter um título universitário, mas trabalhar incansavelmente para que outros o obtenham. Me faltam palavras para expressar toda a gratidão pela dedicação, disposição e boa vontade que sempre tiveram comigo.

A Clara Carniol pela amizade e alegria que sempre transmitiu. Os maiores gestos de amizade são aqueles que permanecem anônimos, porque no anonimato se esconde a verdadeira intenção desvinculada.

A Monika Vieira de Arruda, uma pessoa que com suas poucas palavras, foi capaz de contribuir de uma maneira indescritivel neste trabalho. Seu exemplo de conduta se fez muito presente na minha formação, apesar do pouco tempo de convívio que tivemos.

A Cyntia Pereira, estagiária de iniciação científica. Cyntia participou ativamente de vários dos experimentos apresentados neste trabalho. Com sua alta capacidade de trabalho, maturidade e seriedade, soube ser muito mais do que uma colaboradora. E, como poucos, soube unir a esta grande competência uma amizade sincera. 
A Ricardo Peres do Souto (Rich), que muito me auxiliou em incontáveis ocasiōes. Muito mais do que um colega, um amigo que atrás de sua timidez esconde grandes qualidades.

Aos estagiários de iniciação científica Camila B. Ramalho, Paulo G. Marmorato, Beatriz Stolf e Denisinha, os quais muito contribuiram na execuçāo deste trabalho.

A Hernando del Portillo (Depto. de Parasitologia - ICB) por várias sugestōes técnicas e protocolos que me ofereceu, além da alegria e amizade que sempre soube transmitir.

A Eufrosina S. Umezawa (Instituto de Medicina Tropical) pela produtiva e agradável colaboração que mantivemos em várias ocasiōes. Agradeço também pelo soro anti-tct e os soros humanos de pacientes chagásicos e com outras parasitoses.

A Pedro Soares de Araújo pela amizade e ensinamentos que sempre me transmitiu, especialmente na informática.

A Hernan Chaimovich pelas poucas mas valiosas palavtas que me ajudaram a tomar decisōes acertadas.

A Wim Degrave (FIOCRUZ - RJ), pela utilização do computador VAX e pelas orientações no uso do pacote $\mathrm{GCG}_{1}$ as quais foram fundamentais para a análise dos dados de seqüenciamento.

A Brazilian Molecular Biology and Biotechnology Network - BMBBnet, EMBRAPA/CENARGEN - Brasília pelo uso do computador IRIS - Silicon Graphics na análise das seqüências nucleoridicas e protéicas.

A Fernando de Castro Reinach, por várias sugestōes científicas que contribuíram para a evoluçāo do trabalho.

A Artur Scherf (Institute Pasteur) pelo vetor pMSgt1l.

A Marco Krieger pelo protocolo de ressolubilização de corpúsculos de inclusão.

A Maria Isabel Cano (Escola Paulista de Medicina), pela eletroforese e transferência de cromossomos de T. cruzi. 
A Jorge Yanovsky (Polychaco ${ }^{\$}$ S.A.I.C - Argentina), pelos dados dos experimentos de ELISA feitos com soros do Instituto Fatala Chaben.

A Egler Chiari (UFMG) e João Carlos Pinto Dias (FIOCRUZ - MG) pelos soros humanos da região de Bambuí.

Aos professores Hamza F. A. El Dorry, Suely L. Gomes e Antonio G. Bianchi por permitirem a utilização de reagentes e equipamentos em seus laboratórios e pelas inúneras sugestões que sempre me deram.

Aos colegas do nosso laboratório: Jesus, Ronaldo, Kumiê, Juan, Ricardo, Carla, Grace, Eloíse, Daniella, Flávio, Luís, Cláudia, Sílvia, Ana Paula, Fátíma, Fernando, Laila, Denise, Martha, ingrid, Lídia e Liliana. Cada qual contribuiu à sua maneira com meu trabalho e todos, em seu conjunto, para o meu engrandecimento.

Aos colegas do laboratório do Prof. Hernan Chaimovich: Teresa Cristina (T.C.), Cláudia, Fábio, Fábio(inho), Ana Paula, Márcia, Maurício, Hyoka, Palmira, Boris e Walter, os quais sempre ajudaram a tomar o nosso ambiente mais alegre.

Aos colegas do Instituto: Flávio Henrique, Jorge, Wilton, Euclides, Carlos Rossini, Pepe, Sheila, Ligia, Horácio, Enny, Margareth, Paulo, Rosane, Júlio, Adriana, Marcelo e Ivan Campos. Obrigado pela amizade e ajuda que vocês sempre me deram.

A Rogério Lacaz Ruiz, a quem devo minha entrada no meio cientifico. Grande amigo, exemplo de condura humana, companheiro de alegrias e frustraçōes.

A Luíza A. Guerino pelo apoio e estímulo incessantes que me ofereceu ao longo do trabalho. Sem esse apoio, possivelmente este trabalho não teria tido êxito.

A minha amiga, companheira dos tempos de iniciação científica, Alda Maria Backx N. Madeira, pelo apoio, estímulo, paciência e amizade que sempre me dispensou.

Esta pesquisa foi financiada com recursos do UNDP/WHO Special Programme for Research and Training in Tropical Diseases, FINEP, FAPESP e CNPq. Agradeço ao CNPq a bolsa de estudos que me permitiu a realização deste trabalho. 


\section{ÍNDICE}

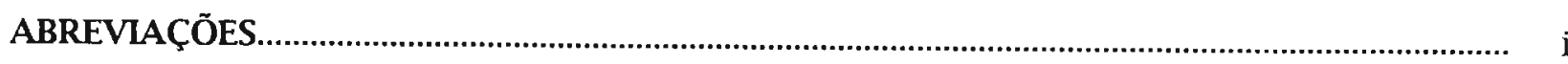

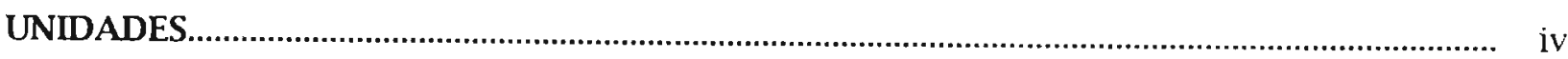

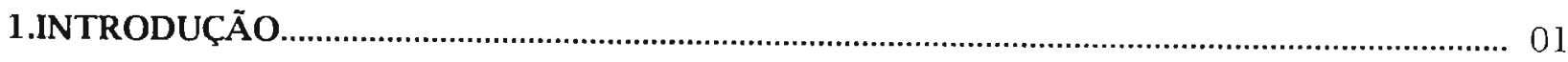

1.1. Aspectos gerais da doença de Chagas............................................................................... 01

1.1.1. Ciclo de vida do Trypanosoma cruzi..................................................................... 01

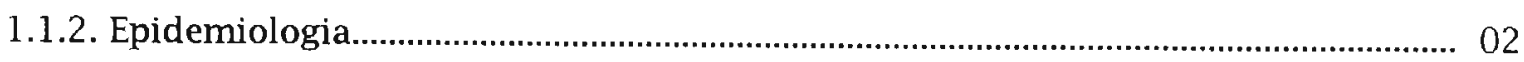

1.1.3. Fases e formas clínicas da doença............................................................................ 04

1.1.4. Caracterização das cepas de T. cruzi........................................................................... 05

1.2. Diagnóstico da doença de Chagas........................................................................................ 07

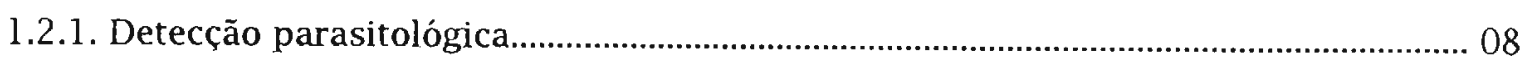

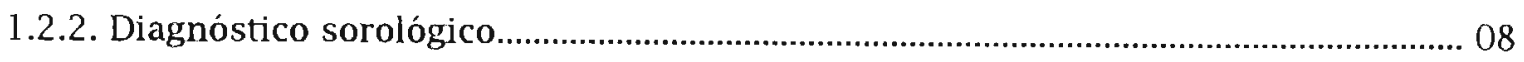

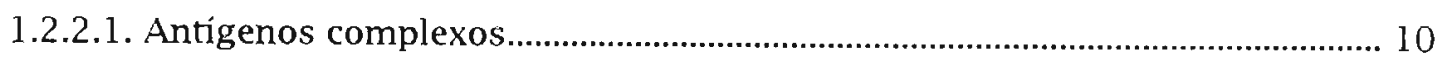

1.2.2.2. Antigenos purificados e recombinantes.......................................................... 14

1.3. Formas de controle da doença de Chagas......................................................................... 18

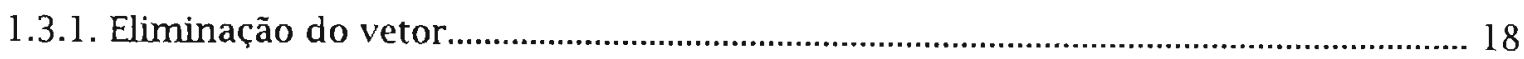

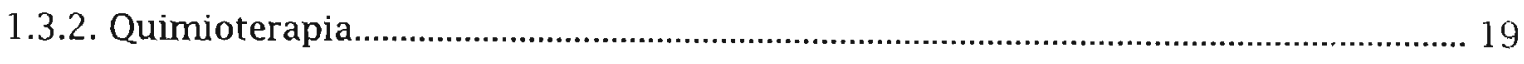

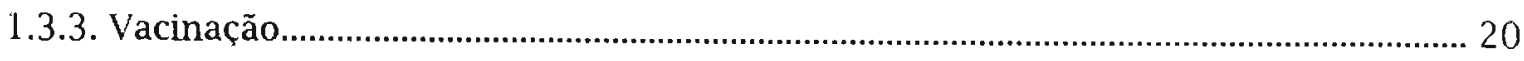

1.4. Aspectos da biologia molecular do Trypanosoma cruzi................................................... 21

1.4.1. Conteúdo de DNA, ploidia e cariótipo....................................................................... 21

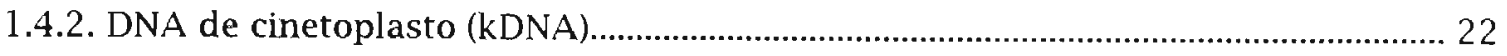

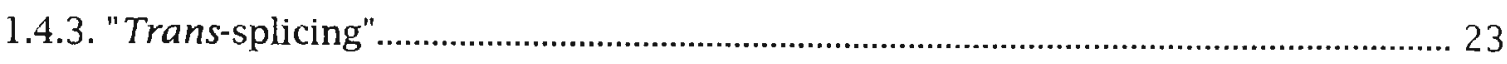

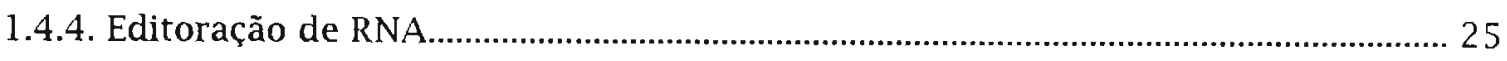

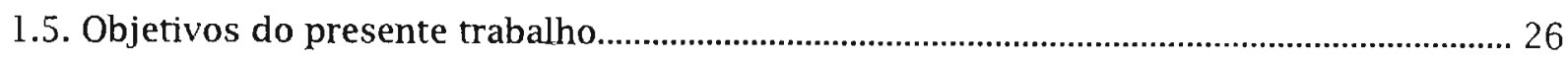

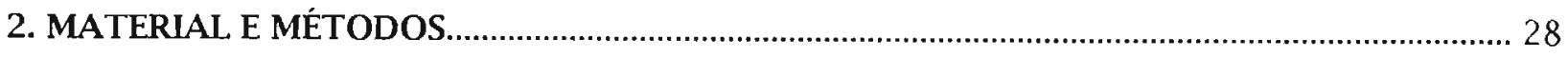

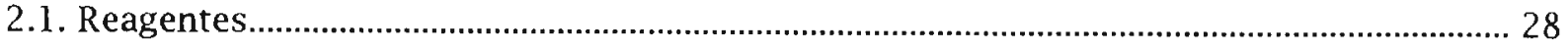

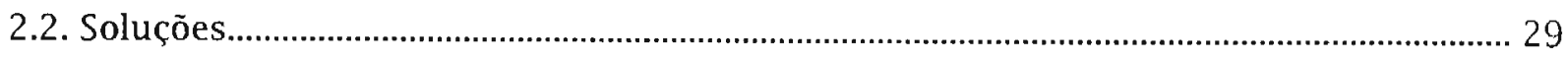

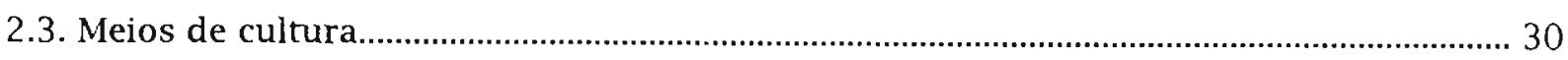

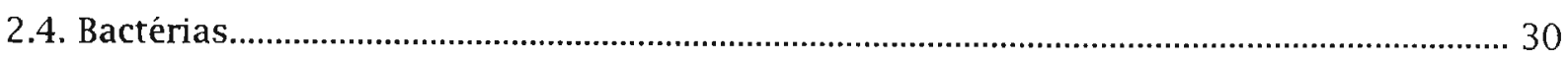

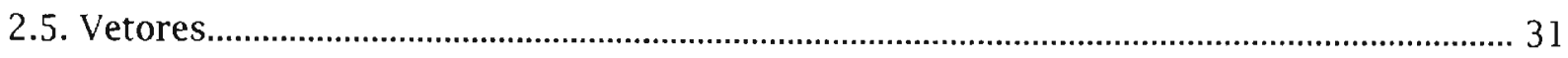

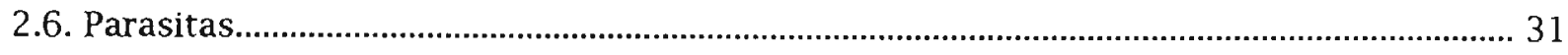

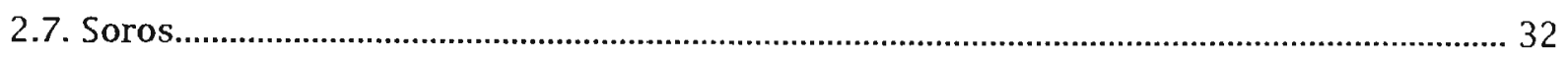

2.7.1. Soro de coelho anti-tripomastigotas de cultura de tecido $(\mathrm{tct})$................................. 32

2.7.2. Obtenção de soros de coelhos anti-proteinas de fusão................................................ 32

2.7.2.1. Emulsificação do antígeno.................................................................................... 32

2.7.2.2. Imunização por inoculações subcutâneas........................................................ 32

2.7.2.3. Imunização por múltiplas inoculações intradérmicas..................................... 33 
2.7.3. Soros humanos.

2.8. Purificaçăo de ácidos nucléicos de $T$. cruzi..................................................................... 33

2.8.1. Preparaçāo simultânea de DNA e RNA.......................................................................... 33

2.8.1.1. Ultracentrifugação em gradience de césio.................................................. 33

2.8.1.2. Obtençāo do DNA....................................................................................... 34

2.8.1.3. Obtençāo do RNA total................................................................................... 34

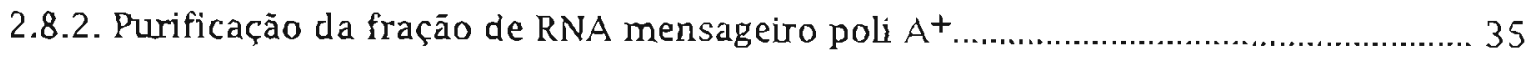

2.8.3. Preparação do RNA pelo método do fenol quente.................................................. 35

2.9. Construçāo de biblioteca genômica de $T$. cruzi no vetor de expressāo $\lambda g t 11 \ldots \ldots \ldots \ldots \ldots . . . . .36$

2.9.1. Preparaçāo dos insertos ............................................................................................. 36

2.9.2. Marcação radioativa dos adaptadores de EcoRI....................................................... 36

2.9.3. Controle da eficiência de fosforilação dos adaptadores............................................. 37

2.9.4. Ligação de insertos com os adaptadores e digestão com EcoRI.............................. 37

2.9.5. Separaçāo do excesso de adapradores não ligados ao DNA dos insertos.................. 38

2.9.6. Reação de ligação entre o DNA de T. cruzi e o DNA de $\lambda$ gr 11 ................................. 38

2.9.7. Encapsidação in vitro do DNA …........................................................................ 38

2.9.7.1. Preparação do extrato de empacotamento sonicado (SE)............................. 38

2.9.7.2. Preparação do extrato de empacotamento

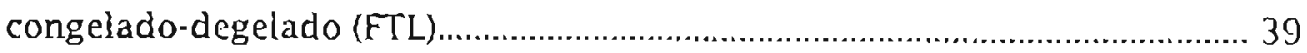

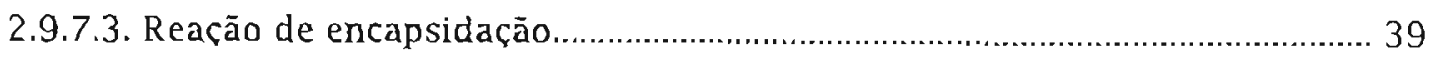

2.9.8. Determinação do título e taxa de recombinaçāo da biblioteca................................... 40

2.10. Varredura da biblioteca genômica de T. cruzi em $\lambda g \mathrm{gl} 11 \mathrm{com}$ anticorpos...................... 40

2.10.1. Absorção do soro anti-tct................................................................................ 40

2.10.2. Seleção dos clones recombinantes.................................................................. $4 \mathrm{l}$

2.11. Varredura de biblioteca genômica de T. cruzi

em $\lambda$ EMBL3 com sondas radioativas....................................................................... 41

2.12. Preparação de sondas de DNA radioativas.................................................................. 42

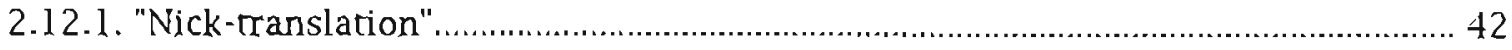

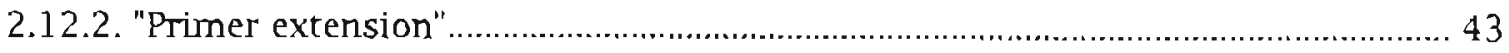

2.12.3. Remoção dos nucleotidios não incorporados...................................................... 43

2.12.4. Determinação da incorporação dos nucleotídios radioativos.............................. 43

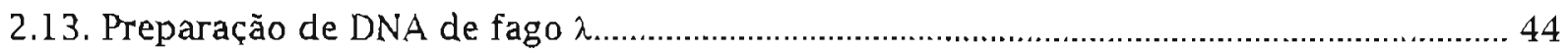

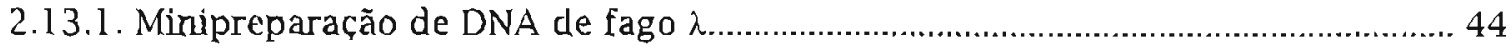

2.13.2. Preparação de DNA de fago $\lambda$ em larga escala...................................................... 44

2.13.2.1. Cultivo de fagos em larga escala .......................................................... 44

2.13.2.2. Purificação de DNA de fago $\lambda$................................................................. 45

2.14. Purificação de DNA de plasmidio.................................................................................... 45

2.14.1. Minipreparaçōes de DNA de plasmídio............................................................ 45 
2.1 4.2. Minipreparaçōes rápidas de DNA ("speed preps").............................................. 46

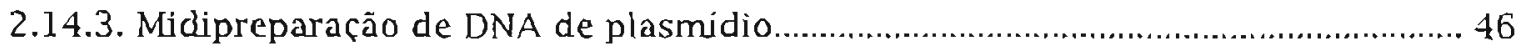

2.14.4. Preparação de DNA de plasmidio em gradiente de cloreto de césio...................... 47

2.15. Subclonagem de fragmentos de DNA .....................................................................48

2.15.1. Digestāo do DNA com enzimas de restrição............................................................ 48

2.15.2. Eletroforese em minigel de agarose.................................................................. 49

2.15.3. Purificaçāo de fragmentos de DNA a partir de géis de agarose de baixo ponto de fusão (agarose LMP) ............................................. 49

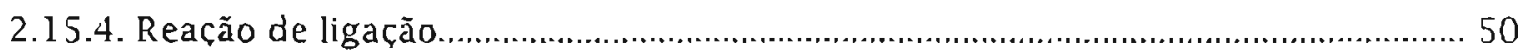

2.15.5. Preparação de células bacterianas competentes e transformaçāo......................... 50

2.15.6. Identificaçāo dos clones recombinantes.................................................................. 51

2.16. Expressāo dos antigenos clonados ................................................................................ 1

2.16.1. Expressão das proteinas de fusão em

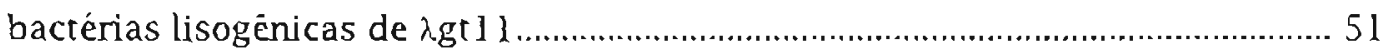

2.16.1.1. Obrenção de bactérias lisogênicas.......................................................... 51

2.16.1.2. Expressão das proteinas de fusão por indução das bactérias lisogễnicas..................................................................52

2.16.2. Subclonagem de B12 e Bl3 em pMISgtl 1 e expressāo (fusão com $\beta$-galactosidase).................................................................. 52

2.16.2.1. Purificaçāo dos insertos e ligação com o vetor....................................... 52

2.16.2.2. Imunoensaio de colônias bacterianas .................................................. 52

2.16.2.3. Produção das proteinas de fusão........................................................... 53

2.16.2.4. Obtençāo do lisado bacteriano............................................................... 53

2.16.2.5. Determinaçāo da solubilidade das proteinas de fusāo........................... 54

2.16.2.6. Cromatografia de afinidade em colunas de pAPTG-agarose................. 54

2.16.2.7. Derecção da arividade de $\beta$-galactosidase ........................................... 55

2.16.3. Subclonagem e expressão do fragmento $\$ 3 S 4$

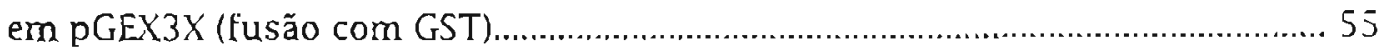

2.16.3.1. Construção do clone pGEX3X-S3S4 ...................................................... 55

2.16.3.2. Cinética de expressão da proteína de fusāo GST-S3S4 …........................ 56

2.16.3.3. Produção de proteína de fusāo................................................................. 56

2.16.3.3.1. Cultivo das células e induçāo.................................................. 56

2.16.3.3.2. Obrenção do lisado das células bacterianas.......................... 56

2.16.3.4. Purificação da proreina GST-S3S4 ........................................................ 57

2.16.3.4.1. Cromatografia de afinidade................................................. 57

2.16.3.4.1.1. Cromatografia de afinidade em resina de GSH-agarose........................................... 57

2.16.3.4.1.2. Detecção da atividade 
2.16.3.4.2.1. Precipitação da proteina de

fusăo GST-S3S4.

2.16.3.4.2.2. Ressolubilização da proreína de

2.17. Unilizaçăo das proteínas de fusāo no diagnóstico sorológico da doença de Chagas. .58

2.17.1. Radioimunoensaio em microplacas..... 58

2.17.2. ELISA 59

2.17.3. Análise estatística 59

2.18. Ensaio de imuno-seleçăo. 59

2.18.1. Acoplamento de proteinas à resina de agarose ativada. 59

2.18.2. Purificação de lgG a partir de soros de pacientes chagásicos 60

2.18.3. Cromatografía de afinidade para obtenção

de anticorpos monoespecíficos. 60

2.19. Eletroforese unidimensional de proteinas em gel de poliacrilamida contendo SDS (SDS-PAGE).

2.20. Ensaio de Western blot. 62

2.20.1. Transferência das proteinas para filtro de nitrocelulose. 62

2.20.2. Coloração do filtro de nitrocelulose. 62

2.20.3. Reação com anticorpos e revelação 63

2.20.3.1. Revelação imunoenzímática. 63

2.20.3.2. Revelaçāo com proteína A radioativa.................................................... 63

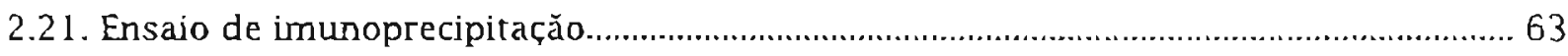

2.21.1. Marcação radioativa da superfície de parasiras.................................................. 63

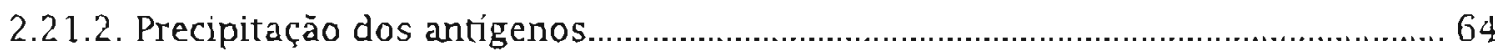

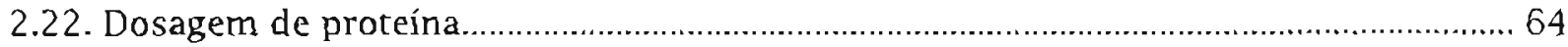

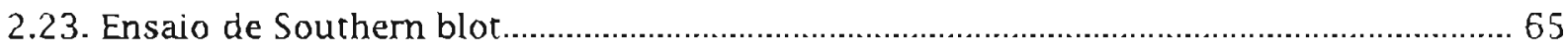

2.23.1. Transferência do DNA para membrana de nylon............................................... 65

2.23.2. Hibridização das sondas com a membrana ..................................................... 66

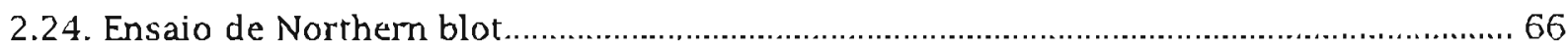

2.24. L. Eletroforese de RNA em géis de agarose/formaldeido........................................ 66

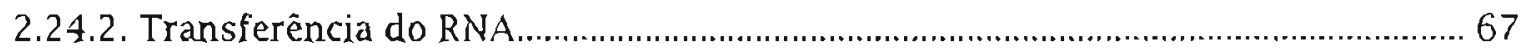

2.24.3. Hibridização das sondas com os filtros de nitrocelulose ........................................... 67

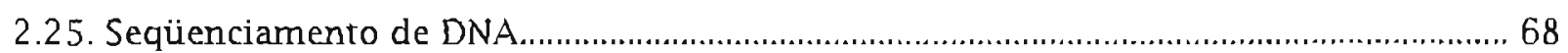

2.25.1. Digestão unidirecional do DNA com Exonuclease III.......................................... 68

2.25.2. Seqüenciamento de DNA de fita simples........................................................... 69 
2.25.2.1. Preparaçāo dos moldes de DNA de fitas simples................................. 69

2.25.2.2. Reaçāo de seqüenciamento.................................................................... 69

2.25.3. Seqüenciamento de DNA de fita dupla.................................................................. 70

2.25.3.1. Preparação dos moldes de DNA

por desnaturação alcalina............................................................................ 70

2.25.3.2. Reação de seqüenciamento com T7 DNA Polimerase ............................. 71

2.25.3.3. Reaçāo altemativa de extensāo com Terminal desoxinucleoridil Transferase (TdT) ........................................................ 72

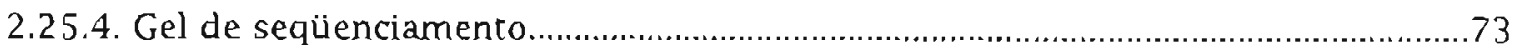

2.25.4.1. Gel de seqüenciamento com

gradiente de força iônica ................................................................ 73

2.25.4.2. Gel de seqüenciamento com

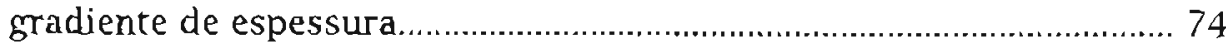

2.26. Análise computacional dos dados das seqüências nucleotidicas................................ 74

2.26.1. Programa DNASIS ................................................................................................ 7 A

2.26.2. Busca de homologia em bancos de dados...................................................... 74

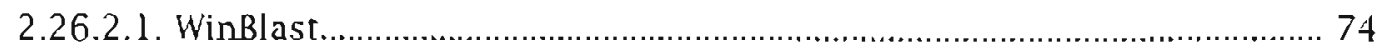

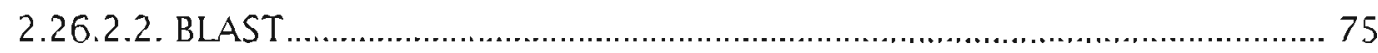

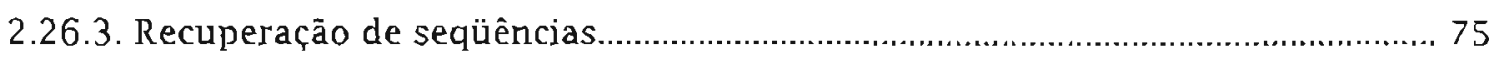

2.26.3.1. Network Entrez .............................................................................. 75

2.26.3.2. Serviço de recuperação de seqüências

por corteio eletrōnico................................................................................. 75

2.26.4. Programas de alinhamento de seqüências

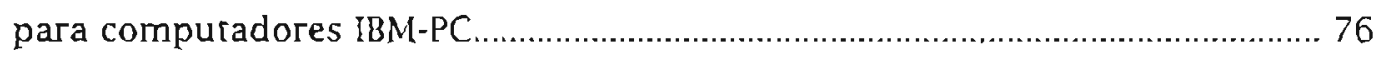

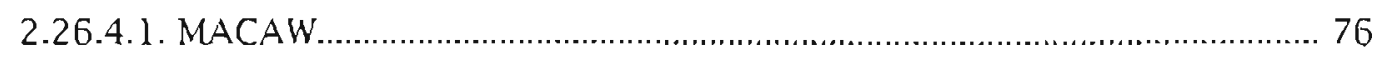

2.26.4.2. Clustal V......................................................................................... 76

2.26.5. Pacote de análise de seqüências GCG ................................................................... 76

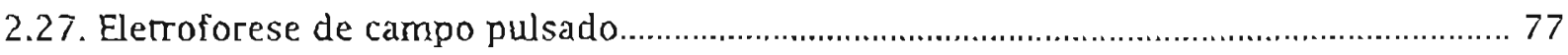

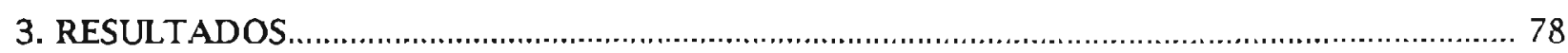

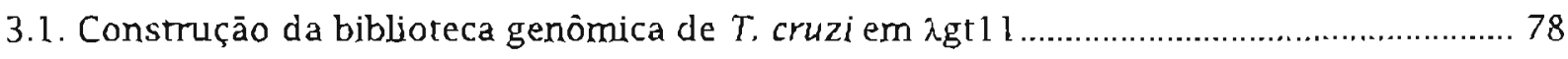

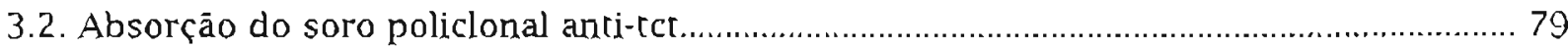

3.3. Isolamento dos clones recombinantes BI2 e B13......................................................... 79

3.4. Subclonagem dos insertos Bl2 e Bl3 para os vetores Ml 3 mpl 8 e pUC18 ..................... 79

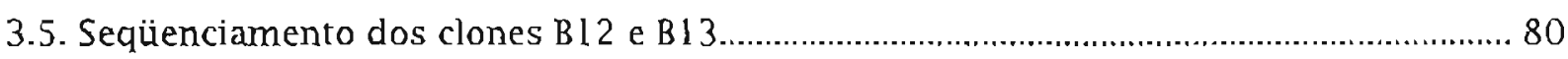

3.6. Análise do arranjo genômico dos clones Bl 2 e B1 3 ...................................................... 80

3.7. Identificação dos transcritos correspondentes a B12 e Bl3.......................................... 83

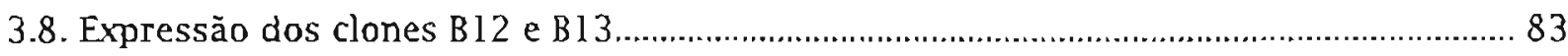

3.8.1. Expressão das proteinas de fusão 
em bactérias lisogênicas Y1089.

3.8.2. Expressāo e purificação das proteínas

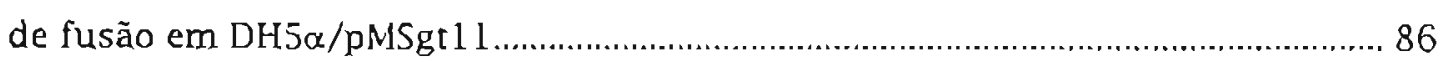

3.8.2.1. Subclonagem de B12 e Bl3 no vetor pMSgt 11 ............................................ 86

3.8.2.2. Expressão das proteínas de fusão Bl 2 e Bl3 ............................................. 87

3.8.2.3. Determinaçăo da solubilidade das proteinas de fusão................................ 87

3.8.2.4. Purificação das proteínas de fusão.................................................................. 88

3.9. Caracterização dos antigenos de $T$. cruzi clonados....................................................... 90

3.9.1. Uso de soros policlonais obtidos por imunização de

coelhos com as proteinas de fusão.......................................................................... 90

3.9.2. Uso de anticorpos humanos imuno-selecionados............................................. 91

3.10. Determinação da localização celular em T. cruzi dos antígenos clonados..................... 91

3.11. Avaliaçăo dos antígenos Bl2 e B 13 no diagnóstico sorologico da doença de Chagas.................................................................................. 93

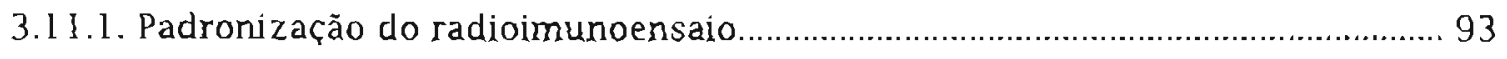

3.11.2. Análise de reatividade de soros humanos por RLA............................................. 95

3.1 1.3. Análise de reatividade de soros humanos por ELISA ........................................ 97

3.12. Isolamento de clones a partir de uma

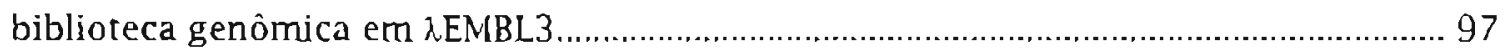

3.13. Determinação do mapa de restrição

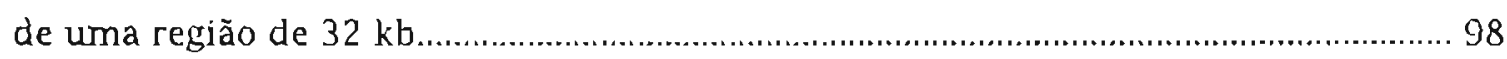

3.14. Expressāo e purificação da protcina GST-S3S4 …....................................................... 100

3.14.1. Construçăo do clone pGEX3X-S3S4................................................................ 100

3.14.2. Expressão da proreína de fusāo GST-S3S4 ...................................................... 102

3.14.3. Purificaçāo da proteína GST-S3S4 ................................................................ 102

3.1 4.3.1. Cromarografia de afinidade em resina GSH-agarose......................... 102

3.14.3.2. Purificação da proteina GST-S3S4 por precipitaçāo seletiva............... 103

3.15. Avaliação do antigeno GST-S3S4 no diagnóstico

sorológico da doença de Chagas.................................................................................. 104

3.16. Utilizaçāo do soro anti-GST-S3S4 em Western blot de lisados de T. cruzí.................. 106

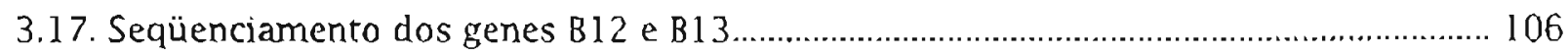

3.17.1 Subclonagem de fragmentos dos clones genômicos........................................ 107

3.17.2. Determinação do número e posição das repetiçōes seriadas............................ 107

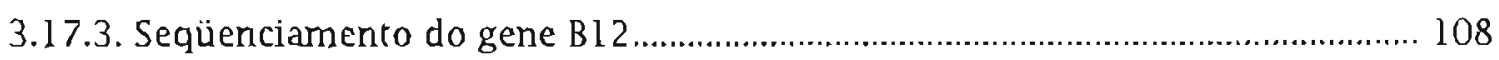

3.17.4. Análíse computacional da seqüência de Bl2 .................................................. 116

3.17.5. Seqüenciamento da regiāo intergênica e 5 ' terminal

do gene Bl3 (fragmento B4H5)...................................................................... 120

3.17.6. Análise computacional da seqüência do fragmento B4H5............................ 120 
3.18. Determinação do mapa de transcrição da região de $32 \mathrm{~kb}$ 124

3.18.1. Caracterizaçào dos transcritos reconhecidos pelos clones genômicos. 124

3.18.2. Identificação de um terceiro gene denominado B11 ...................................... 124

3.19. Caracterização do gene Bl l ..................................................................................... 126

3.19.1. Estudo do arranjo genômico do clone SEl ................................................. 126

3.19.2. Seqüenciamento do fragmento SEl ............................................................ 126

3.20. Estudo do arranjo cromossomal dos genes 811, Bl2 e Bl3 .................................. 131

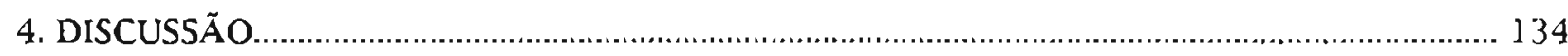

4.1. Um novo método de absorção de soros................................................................ 134

4.2. Diagnóstico sorológico da doença de Chagas................................................................. 135

4.3. Identificação e caracterização dos antigenos clonados................................................. 143

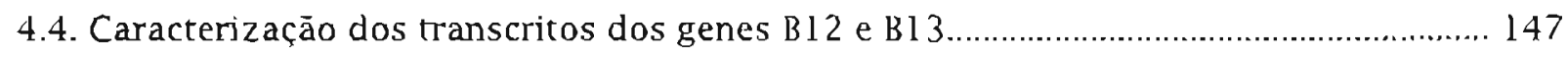

4.5. Artefatos de recombinação........................................................................................ 147

4.6. Caracterização dos genes Bl2 e Bl 3........................................................................ 149

4.7. Análise das seqüèncias nucleotidicas e protéicas de B12 e B13 ................................. 154

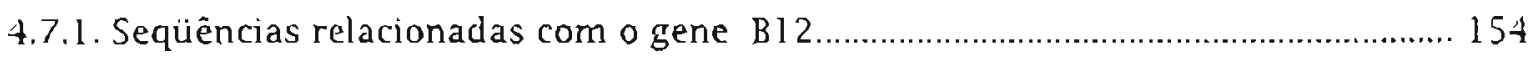

4.7.2. Seqüências relacionadas com o gene B13....................................................... 164

4.8. Caracterização do gene B1 l e sua relaçào com retrotransposons.................................... 165

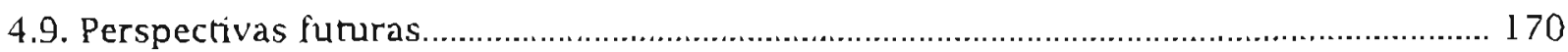

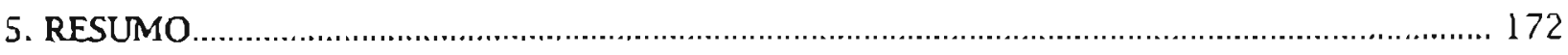

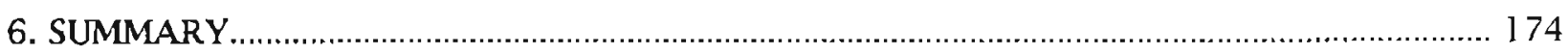

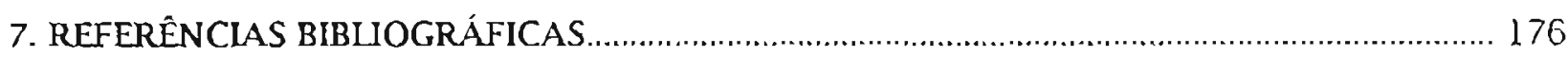




\section{ABREVIAÇŌES}

pAPTG - p-aminofenil- $\beta$-D-tiogalactopiranosidio

ATP - adenosina trifosfato

BSA - soroalbumina bovina

cDNA - DNA complementar

CDNB - 1-cloro-2,4-dinitrobenzeno

DEAE - dietilaminoetil

DEP - dietilpirocarbonato de sódio

DME - meio de Eagle modificado por Dulbecco

DMSO - dimetilsulfóxido

DNA - ácido desoxiribonuclèico

DNase - desoxiribonuclcase

D.O. - densidade óptica

DOS - "disk operaning system" (sistema operacional em disco)

dATP - desoxiadenosina trifosfato

dCTP - desoxicitidina trifosfato

ddNTP - abreviação coletiva para didesoxinucleosidios mifosfaro (ddATP, ddCTP, ddGTP e ddTTP)

dGTP - desoxiguanosina trifosfato

dNTP - abreviaçāo coletiva para desoxinucleosidios trifosfato (dATP, dCTP, dGTP e dTTP)

dTTP - desoxitimidina trifosfato

DTT - ditiotreitol

EDTA - àcido etilenodiaminoterracético

ELISA - enzyme-linked jmmunosorbent assay (ensaio imunoenzimático)

FTP - "file transfer protocol" (protocolo de transferência de arquivos)

$\beta$-gal - $\beta$-galactosidase

gRNA - RNA guia

GSH - glutationa reduzida

GST - glutationa S-transferase

IPTG - isopropil- $\beta$-D-tiogalactopiranosidio

IRMA - immunoradiometric assay (ensaio imunoradiométrico)

kDNA - DNA de cinetoplasto

LIT - infusāo de fígado e triptose

LMP agarose - agarose de baixo ponto de fusāo

MES - ácido 2-(N-morfolìno) etanosulfônico

8-MOP - 8-metoxipsoralen 


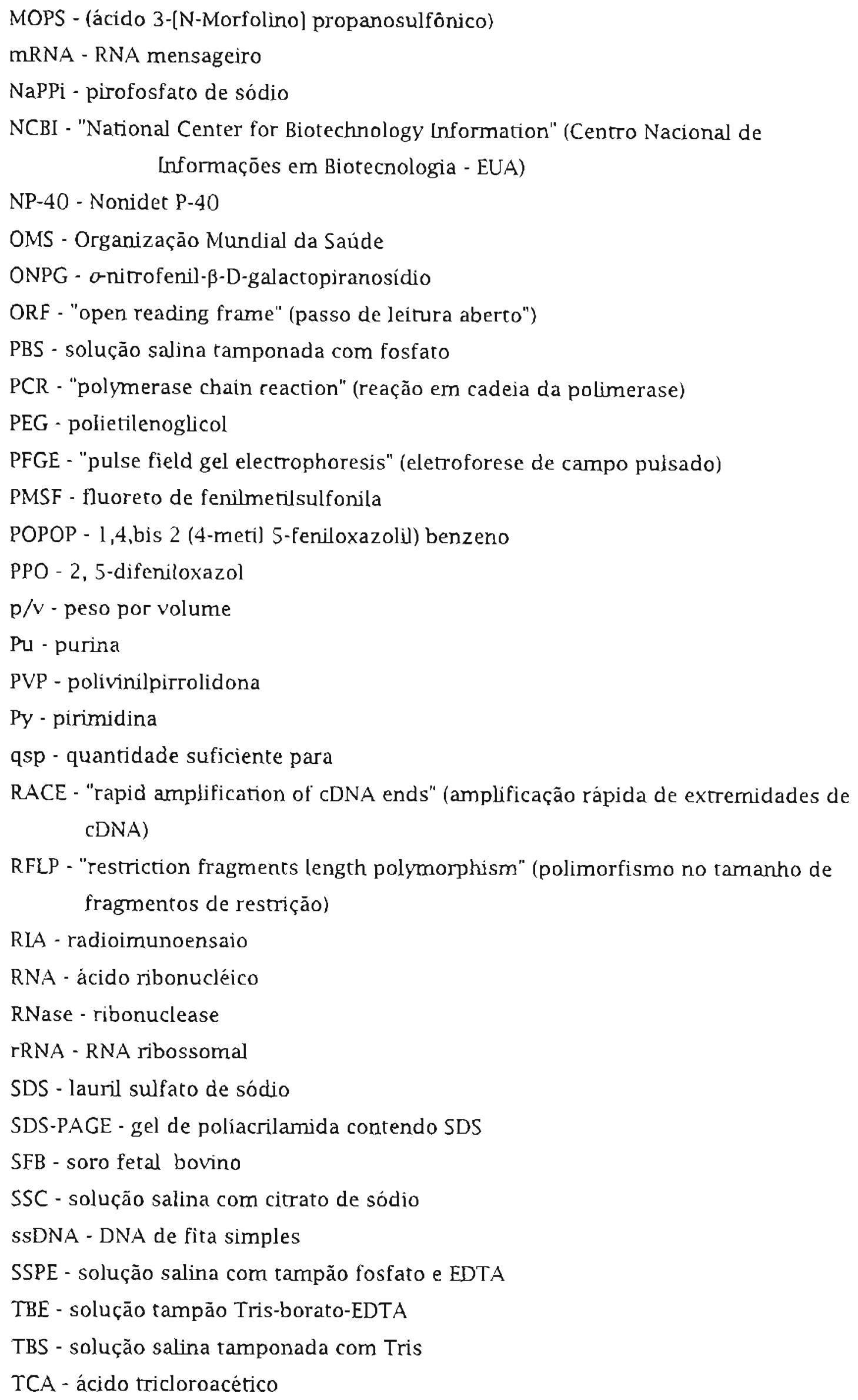


TCP/IP - "Transmission Control Protocol/Internet Protocol" (Protocolo de Controle de Transmissão/Protocolo (nternet)

tct - tripomastigotas de cultura de tecido

TdT - terminal desoxinucleotidil transferase

TE - Tris-EDTA

TEMED - N, N, N', N'- tetrametiletilenodiamina

TLCK - N $\alpha-p$-Tosil-L-lisina clorometil cetona

Tris - Tris[hidroximetillaminomerano

TSM - soluçāo salina com magnésio tamponada com Tris

Tween 20 - monolaurato de polioxietilenosorbitana

UV - ultravioleta

VSG - "variant surface glycoproteins" (glicoprotéinas variantes de superfície)

$v / v$ - volume por volume

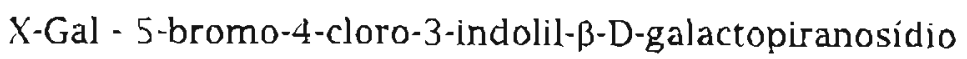




\section{UNIDADES}

$\mathrm{Ci}$ - Curie $\left(1 \mathrm{Ci}=3,7 \times 10^{10}\right.$ desintegraçōes por segundo $\left.=3,7 \times 10^{10} \mathrm{~Bq}\right)$ cm - centímetro

cmHg - centimetros de mercúrio

cpm - contagens por minuto

dpm - desintegraçōes por minuto

fg - fentograma

g - aceleração da gravidade

g- grama

$\mathrm{kb}$ - quilobase

$\mathrm{kDa}$ - quilodalton - 1.000 unidades de massa atômica

( 1 dalton $=1$ u.m.a. $=1,660 \times 10^{-24} \mathrm{~g}$ )

L - litro

mA - miliamperes

$\mathrm{Mb}$ - megabases

mg - miligrama

$\mathrm{mL} \cdot$ mililitro

mm - milimetro

$\mu \mathrm{Ci}$ - microcurie $\left(\mathrm{l} \mu \mathrm{Ci}=3,7 \times 10^{4} \mathrm{~Bq}\right)$

$\mu \mathrm{g}$ - micrograma

$\mu \mathrm{L}$ - microlitro

ng - nanograma

nm - nanômetros

$\mathrm{pb}$ - pares de bases

rpm - rotaçôes por minuto

$\mathrm{U}$ - unidades

UFP - unidades formadoras de placas de lise

V-volt 


\section{INTRODUÇÃO}

\subsection{Aspectos gerais da doença de Chagas}

A doença de Chagas, também chamada tripanossomíase americana, afeta cerca de 24 milhões de pessoas na América Latina (Schofield, 1985). No Brasil existem cerca de 5 milhões de infectados e um total de 25 milhões de pessoas vivendo em áreas endêmicas, as quais correspondem a 3 milhões de quilômetros quadrados (cf. Dias, 1987). O agente etiológico é o Trypanosoma cruzi, um protozoärio hemoflagelado digenético pertencente à familia Trypanosomatidae e ordem Kinetoplastida. Esses parasitas se caracterizam pela presença de um flagelo e uma única mitocôndria, na qual se situa o cinetoplasto, uma organela especializada contendo DNA (cf. Brener, 1973). Na ordem Kinetoplastida encontram-se duas seçōes: a Salivaria e a Stercoraria. Na primeira situam-se os tripanossomas africanos, cuja diferenciação é completada no aparelho bucal do inseto vetor (gênero Glossina) e a transmissão ocorre pela saliva do vetor. O $T$. cruzi por sua vez, pertencente à seçāo Stercoraria, completa seu desenvolvimento na porçāo terminal do intestino do inseto reduvídeo, é eliminado pelas fezes e transmitido ao hospedeiro vertebrado pela ferida da picada, abrasōes da pele ou através de membranas mucosas (Clayton, 1988). Entre as espécies da seção Stercoraria, o T. cruzi é a única espécie digenética a produzir uma patogenia clara e bem estabelecida no homem, na qual as formas sangüineas têm de penetrar em células do hospedeiro para se multiplicarem (Colli et al., 1981).

\subsubsection{Cíclo de vida do Trypanosama cruzi}

O T. cruzi apresenta três formas morfogéneticas ou evolutivas ao longo de seu ciclo de vida. Para a nomenclatura dessas formas (Hoare \& Wallace 1966), adotou-se a raíz mastigota (do grego $\mu \alpha \sigma \sigma_{\xi}=$ chicote) e prefixos que designam a disposição do flagelo na célula, determinada pelo seu ponto de inserção (indicado pela posição do cinetoplasto), seu curso e ponto de emergência. Dessa forma, o antigo estágio "leishmanial", que apresenta formas redondas sem flagelo externo, foi denominado amastigota. O epimastigota refere-se às formas "critidiais", apresentando um flagelo que se inicia próximo a um cinetoplasto justanuclear e emerge na porção lateral da célula. A forma tripomastigota, representando as antigas "formas verdadeiras de tripanossomas", apresenta um cinetopiasto posterior ao núcleo. O flagelo surge próximo e corre ao longo da célula formando uma membrana ondulante.

A transmissão da doença se dá pela picada do barbeiro seguida da deposição de fezes e urina que contém tripomastigotas metaciclicos infectantes (Brener, 1973; Tanowitz 
et al., 1992). Os tripomastigotas metacíclicos podem infectar o hospedeiro vertebrado pela porta de entrada da picada, ou ativamente por membranas mucosas. As formas tripomastigotas no sangue podem ser fagocitadas ou ainda penetrar ativamente em células (cf. Tanowitz et al., 1992). Tripomastigotas sāo refratários à lise mediada por complemento, ao passo que formas epimastigoras ativam a via alternativa do complemento. $O$ tripomastigota penetra em uma variedade de células, mas as preferidas são as da glia e de músculo, especialmente cardiaco (Brener, 1973; Vickerman, 1985). Os tripomastigotas, quando fagocitados, conseguem escapar do vacúolo fagocítico e văo se diferenciar no citoplasma da célula. Essa característica não é observada em epimastigotas, os quais acabam sendo destruidos no fagolisossoma (Colli et al., 1981). Cerca de 3 horas após a penetração, o tripomastigota se diferencia em amastigotas. Após um período de quiescência de 35 horas, os amastigotas passam a sofrer uma divisão binária a cada 12 horas. No fina\} de 4 a 5 dias pode haver de 50 a 300 parasitas por célula (Brener 1973; Vickerman, 1985), os quais promovem sua lise e atingem a circulação sangüínea. Esses tripomastigotas, denominados sangüineos, podem então invadir outras células do hospedeiro vertebrado.

O hospedeiro invertebrado se infecra pela ingestão de sangue contaminado com tripomastigotas sangüineos. Após ingestão, os tripomastigotas atingem o estômago e se diferenciam em epimastigotas. No intestino médio do vetor as formas epimastigoras se multiplicam e, após cerca de 3 a 4 semanas, se diferenciam em tripomastigotas metacíclicos, que podem então ser encontrados na porção final do intestino (cf. Brener 1973; Tanowitz et al., 1992; Zingales e Colli, 1985) Os epimastigotas podem ser cultivados em meios axênicos nāo definidos, entre os quais o mais amplamente utilizado tem sido o LIT (Castellani et al. 1967). Em condiçōes especiais de cultivo os epimastigotas padem se diferenciar em tripomastigotas metacíclicos (Contreras et al., 1985).

As formas tripomasngotas podem ser obtidas a partir da diferenciação de epimastigotas em meios de cultura axênico (tripomastigotas derívados de meio axênico), de células em cultura (tripomastigotas de cultura de tecido) ou do sangue de animais infectados (Tripomastigotas sangǘneos). Embora esses parasitas, obtidos de diferentes meios, sejam morfologicamente similares, é possivel que apresentem variações fisiológicas e de patogenicidade (Zingales e Colli, 1985). Desta forma, conclusōes experimentais obtidas com um tipo de tripomasrigota nāo deveriam ser generalizadas para os outros tipos sem prévia demonstraçāo experimental.

\subsubsection{Epidemiologia}

A via de transmissāo pelo vetor è epidemiologicamente a mais importante sendo responsável por cerca de $80 \%$ dos casos (Dias, 1987). O T cruzi é transmitido por insetos hemípteros da família Reduviidae, subfamília Triatominae, conhecidos genérica e 
popularmente com os nomes de "barbeiro", "chupão" e "chupança" (cf. Wendel \& Brener, 1992). As principais espécies do vetor implicadas na transmissão da doença de Chagas são o Triatoma infestans, Panstrongylus megistus e Rhodnius prolixus (cf. Zingales e Colli, 1985). O barbeiro está presente em uma faixa extensa das Américas, compreendida entre as latitudes $40^{\circ} \mathrm{N}$ a $46^{\circ} \mathrm{S}$ (Schofield, 1985). Os reservatórios domésticos e silvestres do parasita são representados por camundongos, ratos, coelhos, hamsters, cobaias, marsupiais e cães. Por outro lado, aves e anfíbios sāo refratários à infecção (Brener, 1973). Além disto, mamíferos grandes como vacas, cavalos e antas não são suscetiveis, enquanto que suinos, ovinos e caprinos apresentam baixos índices de parasitemia (Dias, 1992). Esses reservatórios estabelecem dois tipos de ciclos: o doméstico e o silvestre. No ciclo silvestre há um equilibrio ecológico no qual os reservatórios nāo sāo muito afetados pela doença. A ocupaçāo desordenada do ambiente pelo homem e animais domésticos pode levar a um desequilibrio, estabelecendo uma domiciliação dos vetores e um proximidade física entre os reservatórios doméstico e silvestre. Nesse caso podem-se estabelecer relaçōes entre os dois ciclos. No ciclo doméstico propriamente dito participam como reservatórios os humanos e animais como cães, gatos e roedores domésticos.

A transfusão sangüinea é uma outra via importante de transmissão da doença de Chagas. Nos Estados Unidos, onde nāo há relatos de transmissão por barbeiros, a transfusão tomou-se um problema preocupante a partir das correntes migratórias originárias do México, da América Central e do Sul (cf. Tanowitz et al., 1992). Um problema análogo têm ocorrido nas grandes cidades brasileiras, que têm recebido o afluxo de populaçōes vindas de áreas rurais endêmicas. Esses migrantes têm aumentado a transmissão por transfusão sanguínea, que atinge cerca de 10.000 a 20.000 novos casos a cada ano (Dias, 1987).

A forma de contágio congênita, embora minoritána do ponto de vista epidemiológico, apresenta uma importância social nas regiões endêmicas. No Brasil admitese um risco de cerca de $1 \%$ das crianças de màes chagásicas adquirirem a doença por essa via (Dias, 1987), o que resulta em 8.000 novos casos nas áreas endêmicas (Dias, 1992). Outras formas de contágio menos freqüentes envolvem o aleitamento, transplante de órgāos e acidentes de laboratório. As formas tripomastigotas têm a capacidade de penetrar membranas mucosas, tornando a via oral teoricamente possível. De fato, há vários relatos de possíveis contaminações orais. Um dos casos envolveu um grupo de 28 pessoas em Catolé do Rocha, Paraiba, que teriam se infectado simultaneamente, em uma festa, pela ingestão de caldo de cana supostamente contaminado com barbeiros esmagados ou com secreções de gambás (Shikanai-Yasuda et al, 1991). 


\subsubsection{Fases e formas clínicas da doença de Chagas}

A doença de Chagas apresenta duas fases clínicas distingüíveis: a aguda e a crônica. Após a penetração do parasita ocorre uma reação inflamatória aguda na porta de entrada, denominada chagoma. A seguir estabelece-se uma linfoadenopatia focal e ciclos de multiplicação do parasita. Sintomas mais graves podem surgir de 7 a 14 dias pós-infecção. Um edema periorbital unilateral e indolor (sinal de Romaña), febre, hepatoesplenomegalia, náuseas, vômitos, diarréias, irritação das meninges também podem ocorrer. Desenvolve-se também uma miocardite de grau variável, podendo apresentar necrose miocitolitica, parasitismos de fibras, alteraçōes eletrocardiográficas. Nessa fase podem ser encontrados tripomastigotas no sangue periférico e liquido cerebroespinal. Nos pacientes que morrem, encontram-se amastigotas em biópsias de tecidos cardíaco e de músculos liso e esquelético (Tanowitz et al., 1992). A parasitemia é alta e pode durar de 1 a 2 meses. Em cerca de 2 a $8 \%$ dos individuos verifica-se uma fase aguda inaparente (Brener, 1987).

Devido a respostas imunológicas e um equilibrio na relação parasita-hospedeiro, a parasitemua na fase crônica é muito baixa (Brener, 1973). Estabelece-se uma resposta protetora com anticorpos líticos desenvolvidos contra tripomastigotas vivos e anticorpos nāo protetores detectados com antigenos ou com parasitas fixados. Esse anricorpos protetores mediariam a lise por complemento, citotoxicidade e fagocitose. Os parasitas são dificilmente encontrados na circulação, sendo necessário proceder-se a um xenodiagnóstico ou hemocultura para sua deteção (Brener, 1987). O prognóstico para os pacientes que atingem a fase crônica é imprevisivel. Cerca de 50 a $60 \%$ dos pacientes nāo apresentam quadro clínico por longos períodos de tempo ou mesmo por toda a vida, caracterizando o que se denomina de "forma indeterminada" da doença de Chagas.

Cerca de 20 a $30 \%$ dos pacientes desenvolvem entre 10 a 20 anos pós-infecção uma forma "cardíaca" caracterizada por uma miocardiopatia de severidade variável. Nesse caso verificam-se alteraçōes eletrocardiográficas, especialmente relacionadas à formação e condução do impulso nervoso. Há um processo longo e progressivo de fibrose e destruição de gânglios parassimpáticos (cf. Brener, 1987; Andrade, 1991). A falha cardíaca pode levar a uma morte súbita e, frequientemente, se observa um aneurisma apical em um ou nos dois ventrículos (Rassi et al., 1992). Estima-se que cerca de 3\% dos pacientes ao ano se convertam da forma indeterminada para a forma cardíaca (Brener, 1987).

Entre 8 a 10\% dos indivíduos apresentam uma forma clinica "digestiva", caracterizada por dilatações patológicas de esôfago e/ou cólon (Brener, 1987). Na forma digestiva há uma perda gradativa de neurônios nos plexos intestinais. Nos casos de megacólon observa-se uma perda de até 50\% dos neurônios, uma dilataçāo sigmoidal ou geral do órgão, levando a sintomas de constipação, úlceras e desenvolvimento de fecalomas. Cerca de $5 \%$ da massa do tecido esofágico è composta pelo plexo mioentérico. A 
degeneraçāo neuronal do sistema nervoso intrínseco compromete a coordenaçāo motora do trato digestivo. Observa-se uma dilatação do órgāo com contraçōes peristálticas retarcladas e disfunçāo do cárdia, o que acarreta uma disfagia, regurgitação, erutação, tosse e até mesmo uma pneumonia de aspiração (Brener, 1987; Tanowitz et al., 1992). Também podem ser encontradas lesões no estômago, vesícula biliar e intestino delgado. Alguns pacientes apresentarn ainda formas mistas.

Interessantemente parece haver uma variabilidade geográfica quanto à prevalência das formas clínicas. Enquanto no Brasil cerca de 10\% dos pacientes apresentam esofagopatia, essa forma clínica não é praticamente observada na Venezuela (Brener, 1987). Uma vez que as lesōes da fase crònica só aparecem muitos anos após a infecção e os parasitas estão presentes em quantidades muito reduzidas, acredita-se que a patogênese observada nāo seja provocada por uma agressāo direta do parasita, mas devida à geraçăo de uma resposta autoimune (Brener, 1982; Andrade, 1991). Há duas grandes correntes de pensamento quanto à origem da autoimunidade. A primeira preconiza que a autoimunidade seja originária da presença de epitopos de reatividade cruzada (mimetismo antigênico). A outra linha afirma que a ativaçāo policlonal que ocorre durante a fase aguda poderia liberar clones "anti-self" que persistiriam por longos periodos de tempo, quebrando a tolerância (cf. Andrade, 1991).

\subsubsection{Caracterização das cepas de $T$. cruzi}

Com relaçâo às características biológicas das cepas, è interessante mencionar aquelas referentes às cepas de $T$. cruzi consideradas "polares": Y e CL. A cepa Y foi isolada de um paciente em fase aguda da doença de Chagas (Silva \& Nussenzweig, 1953) enquanto a CL foi obtida a partir do vetor Triatoma infestans coletado em uma casa e infectado naturalmente (Brener \& Chiari, 1963). As duas cepas apresentam diferentes comportamentos biológicos frente a uma série de parâmetros (cf. Brener, 1980). Em ensaios de aglutinação, parasitas da cepa $Y$ aglutinam na presença de anticorpos anti-CL e anti-Y, enquanto que a cepa $C L$ não $\dot{e}$ aglutinada por nenhum desses soros. Camundongos imunizados passivamente com anticorpos contra as cepas Y e CL demonstram menores indices de parasitemia e mortalidade quando desafiados com parasitas da cepa $Y$, enquanto que com a CL não se observam diferenças em relação ao grupo controle. Com relação à lise mediada por complemento humano, a cepa $Y$ é sensivel e a CL resistente. Melo \& Brener (1978) realizaram infecções comparativas entre as cepas $Y, C L$, Berenice e $A B C$ em camundongos. As cepas $Y$ e Berenice apresentaram o mesmo padrão de parasitemia, com um pequeno pico no $5^{\circ}$ dia, um aumento repentino no $7^{\circ}$ dia e uma posserior queda. A cepa $A B C$ apresentou um declínio mais lento e um longo período de infecção, enquanto a cepa $C L$ apresentou uma parasitemia gradual e crescente. Com relação ao tropismo, foi verificado 
um acúmulo muito grande de parasitas da cepa $Y$ no baço, com pico no $7^{\circ}$ e $8^{\circ}$ dias, enquanto a cepa $\mathrm{CL}$ praticamente não invadiu esse órgāo. O mesmo resultado foi observado para as células de Kuppfer do figado. Por outro lado, a presença de pseudocistos no coraçăo e músculos esqueléticos foi muito baixo nas cepas $Y$ e Berenice e gradualmente crescente com as cepas CL e ABC. O tropismo pela musculatura lisa foi relativamente baíxo nas cepas $Y$ e $C L$ e alto com $A B C$ e Berenice. Em virtude do tropismo da cepa $Y$ por células fagocitárias de baço, fígado e medula óssea, ou seja, células do sistema monocítico fagocitario, ela é denominada "macrofagotrópica". Por outro lado, a cepa $C L$, que prefere penetrar células da musculatura cardíaca e esquelética, é considerada "miotrópica" (Melo \& Brener, 1978; Brener, 1980).

O T. chuzi apresenta uma heterogeneidade muito grande entre os diferentes isolados obtidos de pacientes, bem como de vetores e reservatórios. Cada isolado de $T$. cruzi é considerado como uma cepa. As diferentes formas clínicas da doença levaram pesquisadores a tentar encontrar uma correlação entre caracteristicas bioquimicas das cepas e as formas clinicas. A classificaçāo de cepas em grupos denominados zimodemas foi baseada na caracterização dos organismos em funçāo da mobilidade eletroforética de suas isoenzimas. Entretanto, em diferentes zimodemas isolados de casos agudos não se observaram diferenças clínicas posteriores, e nem diferentes resistências a quimioterápicos (Miles \& Cibuiskis, 1986). Também se verificou que as cepas isoladas podem conter uma mistura heterogênea de zimodemas (infecção mista), a qual pode se modificar após crescimentos seriados in vivo e in vitro. Entretanto, as características dos zimodemas são mantidas estavelmente em populações clonais.

Tibayrenc et al. (1986) realizaram um estudo abrangente de padrões isoenzímicos envolvendo 14 enzimas diferentes e 121 estoques de $T$. cruzi. A classificação previamente estabelecida de 3 zimodemas (Miles \& Cibulskis, 1986) passou a ter 43 grupos de isoenzimas. A maior parte das cepas demonstrou variaçōes genéticas, indicando uma substancial divergência. O estudo dessas cepas isoenzímicas revelou um padrão de heterozigose, levando à conclusão que o parasita é diplóide. Essa heterozigose se mostrou fixa em vários loci examinados e estável ao longo de geraçòes, o que é incompativel com o padrão de segregação Mendeliana. Esse dado, aliado ao fato de muitos genótipos teóricos nāo estarem presentes na população de parasitas e da existência de um forte desequilíbrio de "linkage" para alguns loci, levaram à conclusão de que a recombinação sexual, se não totalmente ausente, é ao menos severamente restrita em T. cruzi (Tibayrenc \& Ayala, 1987). A população de $T$. cruzi seria portanto complexa e teria um padrão multiclonal. A alta heterogeneidade bioquímica das diferentes cepas isoladas é compańvel com uma evolução clonal remota seguida de uma evolução independente dos múltiplos clones (Tibayrenc et al., 1986; Tibayrenc \& Ayala, 1987). A partir do escudo de diferentes organismos, Tibayrenc et al. (1990) propuseram generalizar a reoria de reprodução clonal para os demais 
protozoários parasitas, baseados no fato que a segregaçāo e recombinação, caracrerísticas de reprodução sexuada, são aparentemente raros nesses protozoários.

Em outra forma de classificação, os grupos, denominados esquizodemas, foram caracterizados em função dos perfis eletroforéticos obtidos por digestões de kDNA (DNA de cinetoplasto) com enzimas de restriçāo (cf. Morel et al., 1986). Novamente não foram encontradas evidências de que determinados esquizodemas estivessem associados a alguma forma clinica da doença. Entretanto, resultados interessantes demonstraram que cepas isoladas podem conter mais de uma subpopulação de parasitas. Além disso foi verificado que cepas cultivadas em diferentes laboratórios, por muito tempo, podem apresentar diferentes perfis de esquizodemas, indicando contaminaçōes e/ou seleçāo de uma subpopulação particular de $T$. cruzi. De fato, os autores demonstraram, por infecçōes com populações mistas, que essa seleçāo tambem pode ocorrer in vivo.

O conjuntos dos dados obtidos pelo estudo de zimodemas e esquizodemas parece indicar que a associação direta de uma cepa com uma dada forma clínica da doença não seja adequada. Uma subpopulaçāo minoritária de um isolado poderia ser a responsável pelos sintomas clinicos observados e ser negativamente selecionada após o cultivo dos parasitas. Embora os zimodemas e esquizodemas obtidos a partir de subpopulaçōes clonadas de diferentes cepas apresentem uma grande heterogencidade, nāo se observam grandes variações nos perfis de suas proteínas de superficie (cf. Zingales e Colli, 1985). Entretanto, esse dado não exclui a possibilidade de haver pequenas variaçōes não derectadas, porém de alta importância em termos de consequêencias clínicas. Um outro aspecto que tem de ser considerado é o fato de que as caracteríscicas clinicas de uma cepa podem ter pouco ou nenhuma correlação com as características bioquimicas analisadas até o momento (Tibayrenc et al. 1988). As propriedades clínicas de uma cepa poderiam ter uma determinação genética independente daquela responsável pelas características bioquímicas. Outra hipótese é de que as propriedades clínicas e biológicas podem ser o resultado de diferentes pressões seletivas em diferentes ambientes e assim, poderiam não ter correlação com as propriedades bioquímicas. De acordo com os autores, como as hipóteses acima não são mutuamente exclusivas, poderiam existir algumas propriedades clínicas correlacionadas com a classificação bioquímica e outras nāo.

\subsection{Diagnóstico da doença de Chagas}

O diagnóstico da doença de Chagas oferece diferentes dificuldades dependendo da fase da doença na qual se encontra o paciente. Na fase aguda a parasitemia é alta, 
permitindo a detecção de parasitas em exames diretos de sangue fresco. O xenodiagnóstico e a hemocultura também sāo freqüentemente empregados. Por outro lado, na fase crônica a parasitemia corna-se muito baixa e o diagnóstico tem de ser feito principalmente por sorologia.

\subsubsection{Detecçāo parasitológica}

O diagnóstico parasitológico na fase aguda, devido à alta parasitemia, pode ser realizado por observação microscópica a partir de amostras de sangue fresco ou de parasitas fixados e corados com Giemsa. A amostra de sangue também pode ser centrifugada (microhematócrito) para aumentar a concentração de parasiras e, conseqüentemente, a chance de detecçāo (cf. Chiari, 1992).

Para o xenodiagnóstico criam-se barbeiros em laboratório, alimentados com sangue de aves, que são refratárias à infecção por $T$. cruzi. Cerca de 40 barbeiros (fase de ninfa), separados em grupos de 10 e colocados em caixas, são utilizados para o exame. As caixas são colocadas sobre a pele do paciente que sofre múltiplas picadas. Os barbeiros, após cerca de 30 a 60 dias, têm o seu conteúdo intestinal e fecal examinado ou utilizado para cultivo em meios de cultura. Esse teste, além de ser desagradável para o paciente, apresenta uma baixa sensibilidade, da ordem de 50\%. Por essa razão, e especialmente na fase crônica, deve ser repetido várias vezes para a obtençào de resultados mais confiáveis. Outro problema é que alguns pacientes apresentam reações cutâneas às picadas dos barbeiros. Nesses casos pode-se coletar o sangue com seringa e anticoagulante e alimentar os vetores em laboratório.

Outro método de diagnóstico parasitológico é a hemocultura. Nesse caso o sangue do paciente é coletado e urilizado para inocular meios de cultura. Há algumas variaçôes nas quais consegue-se enriquecer a amostra com parasitas através de etapas de centrifugaçào. A sensibilidade do método é semelhante àquela do xenodiagnóstico e dados mais confiáveis são obtidos mediante repetições do teste e/ou sua realização concomitante com o xenodiagnóstico. A baixa parasitemia da fase crônica toma ambas as técnicas pouco sensíveis. Chiari e Вrener (1966) compararam os resultados de xenodiagnóstico e hemocultura com o teste de fixação de complemento. Dos 35 soros de pacientes chagásicos em fase crônica, positivos na reação de fixaçāo de complemento, 31,4\% foram detectados pelo xenodiagnóstico, $25,7 \%$ pela hemocultura e $42,8 \%$ pelo uso conjunto de ambas as técnicas.

Uma aiternativa promissora para a detecçāo parasitológica surgiu na segunda metade da década de 80 com o desenvolvimento da técnica de PCR (reação em cadeia da polimerase). A existência de DNA repetitivo e abundante tanto no núcleo (González et al., 1984) como no cinetoplasto (Simpson, 1987) do $T$. cruzi permite o desenvolvimento de 
métodos de detecção e caracterização do parasita por sondas de DNA. O kDNA de $T$. cruzi apresenta 5.000-10.000 minicírculos de 1,42 kb, os quais contém quatro repetições de 120 pb, conservadas entre as diferenças cepas (Degrave et al., 1988). Utilizando iniciadores da região conservada das repetições, Sturm et al. (1989) desenvolveram um teste de PCR que permitiu a detecção de 0,015 fg de DNA molde (equivalente a $0,1 \%$ do conteúdo de minicírculos de um parasita) ou ainda de 10 tripomastigotas em $100 \mu \mathrm{L}$ de sangue. Foi verificado que esse iniciadores não amplificavam nenhum produto a partir de DNA de $T$. rangeli ou de Leishmania. Uma das dificuldades de aplicação do PCR no diagnóstico da doença de Chagas seria a degradação do DNA nas amostras de sangue. Neste sentido, Avila et al. (1991) desenvolveram um sistema de conservação das amostras utilizando guanidina e EDTA, que manteve a estabilidade do DNA a $37^{\circ} \mathrm{C}$ por pelo menos um mês. Além disso, esses autores procederam a uma clivagem química da malha de kDNA com 1,10 fenantrolina- $\mathrm{Cu}^{+2}$, linearizando os minicírculos e permitindo uma melhor distribuição dessas moléculas nos lisados. Utilizando os mesmo iniciadores descritos por Sturm et al. (1991), o limiar de detecção do teste passou a ser de um parasita em $20 \mathrm{~mL}$ de sangue. Esse teste foi aplicado em um painel de 114 soros de pacientes chagásicos e não chagásicos, comparando-se os resultados com testes sorológicos e de xenodiagnóstico. Todas as amostras positivas nos testes sorológicos e de xenodiagnóstico também foram positivas no PCR (Avila et al., 1993). Três amostras negativas na sorologia foram positivas no PCR. Recentemente, Wincker et al. (1994) propuseram um procedimento simples de linearização dos minicírculos, utilizando fervura, seguido de PCR. Os autores testaram o método em um total de 100 soros de pacientes e verificaram uma sensibilidade de 96,5\% em comparação com testes sorológicos. Além disso, 21 pacientes com xenodiagnóstico negativo e 4 com sorologia duvidosa foram positivos no PCR, indicando que este método pode ser um bom teste complementar à sorologia, além de ser a técnica mais sensivel de detecçāo de parasitas na fase crônica da doença de Chagas.

A utilizaçāo de PCR para a detecçāo de DNA nuclear foi descrita por Moser et al. (1991) utilizando um elemento repetitivo de 188 pb de DNA de minisatélite e que apresenta um número de cópias 1,8 vezes maior do que o dos minicírculos. A reação apresentou uma sensibilidade de 8 parasitas em $100 \mu \mathrm{L}$ de sangue, sem amplificação de DNA humano ou de Leishmania e tripanossomas africanos. Esse teste também pode ser realizado a partir de soros, o que diminui a manipulação e facilita o transporte das amostras (Russomando et al. (1992). Diaz et al. (1992) também utilizaram sondas de minisatélite e obtiveram uma sensibilidade de 1 parasita em $10 \mathrm{~mL}$ de sangue. Para reduzir o efeito inibitório do sangue na reação de PCR, esses autores lisaram as células com NP-40 e extraíram o DNA a partir dos núcleos. Outra seqüência nuclear, proposta para o diagnóstico da doença de Chagas é o elemento E13 (Requena et al., 1992), que apresenta 10.000 a 20.000 cópias por genoma e um tamanho de $1025 \mathrm{pb}$. Segundo os autores, utilizando a técnica de PCR com dois 
iniciadores conservados, foi possivel detectar $1 / 30$ de uma célula do parasita. Como o elemento E13 não está presente em Leishmania e T. rangeli, poderia ser utilizado para o diagnóstico específico de T. cruzi.

Finalmente, foi proposto um teste de PCR utilizando como sonda uma sequêencia de cerca de $100 \mathrm{pb}$ da subunidade 24Sa de rRNA (Arruda et al, 1990), específica de T. cruzi (Souto \& Zingales, 1993). Essa seqüência está presente em cerca de 114 genes nucleares e cerca de 60.000 cópias de rRNA por célula. A técnica proposta para a amplificação desta seqüência consiste em uma transcrição reversa acoplada ao PCR, obtendo-se um limiar de detecçāo de $0,1 \%$ do ácido nucléico total de uma célula do parasita. Não foi verificada uma reatividade cruzada com diferentes espécies de Leishmania e com T. rangeli. Entretanto, um problema complicador que se observa para a aplicaçāo desra abordagem para o diagnóstico parasitológico da doença de Chagas é a extrema labilidade dos RNAs-alvo no sangue de indivíduos infectados (Souto \& Zingales - comunicação pessoal). Um dado interessante observado pelos autores é o dimorfismo da seqüência alvo entre as diferentes cepas de $T$. cruzi. Tal resultado parece indicar que essa sequência ribossomal, além de poder ser utilizada na deteçāo do parasita, pode também ser útil na tipagem de cepas e estudos de variações intraespecíficas no $T$. cruzí.

Os resultados apresentados acima parecem indicar que a técnica de PCR pode se tornar, com alguns aprimoramentos, uma alternativa viável e sensivel para a deteccão de $T$. cruzi, especialmente na fase crônica, onde há uma baixa parasitemia. Os volumes de 10-20 $\mathrm{mL}$ necessários para o teste săo semelhantes àqueles utilizados $\mathrm{cm}$ xenodiagnóstico (cf. Avila et al., 1991). É provável que avanços récnicos na manipulaçāo das amostras e exrração do DNA/RNA aumentem ainda mais a sensibilidade do método.

\subsubsection{Diagnóstico sorológico}

\subsubsection{Antigenos complexos}

O diagnóstico sorológico é realizado principalmente na fase crônica, na qual a parasitemia é muito baixa e os sintomas clínicos nem sempre perceptíveis. Desde a descoberta da doença de Chagas várias técnicas de diagnóstico sorológico foram desenvolvidas.

A fixação do complemento, também conhecida como reação de Guerreiro e Machado, foi proposta em 1913 como altemativa ao xenodiagnóstico na fase crônica da doença (cf. Ferreira, 1992). Esse teste empregava como antígeno um extrato aquoso de baço de cães pesadamente infectados com $T$. cruzi. Devido à sua composição complexa, esse "antigeno" apresentava problemas relativos à estabilidade, especificidade e poder fixador (cf. Muniz \& Freitas, 1944). Embora a fixaçāo do complemento tenha sido aprimorada ao longo dos anos, 
permanece sendo uma técnica bastante complexa, uma vez que envolve uma grande quantidade de reagentes além do soro reste: antigeno, complemento, hemáceas e hemolisina. Cada um desses reagentes pode apresentar variabilidades em diferentes lotes e laboratórios, exigindo uma série de controles que tornam esta técnica tediosa e de difícil padronização.

Uma alternativa à fixação de complemento foi proposta por Muniz e Freitas (1944), que utilizaram parasitas inteiros e fixados em um ensaio de aglutinaçāo direta. Uma dificuldade desse ensaio é que na dependência do tipo de cultivo, pode ocorrer aglutinação espontânea dos parasitas. Muniz e Freitas (1944) compararam a aglutinação direta com a fixação do complemento e verificaram uma alta concordância entre os dois métodos. Entretanto, foi verificado que soros chagásicos agudos eram capazes de promover aglutinação de Leishmania, sugerindo que podem ocorrer reações cruzadas entre esses dois parasitas.

Outro teste muito empregado em rotinas de laboratórios clínicos é a hemaglutinação passiva. Nesse teste as hemáceas são tratadas com um agente acoplante como o ácido tânico e revestidas com extratos de $T$. cruzi. A presença de anticorpos no soro da amostra é evidenciada pela aglutinaçāo das hemáceas. Neal \& Miles (1970) utilizando hemáceas de carneiro sensibilizadas com extratos de epimastigotas da cepa $Y$, adaptaram o método com o uso de amostras de sangue obtidas por puntura digital e sêcas em papel de filtro. Foi demonstrado que os filtros mantém os anticorpos estáveis e que altos títulos são detectados mesmo após meses de armazenamento. Entretanto, foram observadas reaçōes cruzadas com Leishmania. Camargo et al. (1973) propuseram um método no qual as hemáceas são sensibilizadas, preservadas com aldeído e estocadas na forma Liofilizada. Os autores analisaram 1.430 soros e verificaram uma concordância de $99.1 \%$ com a fixaçāo de complemento e $99,6 \%$ com a imunofluorescência. Tambèm observaram que as hemáceas se mantém estáveis por pelo menos um ano a $4^{\circ} \mathrm{C}$.

O teste de floculação emprega fragmentos de parasitas liofilizados e apresenta alta sensibilidade, inclusive em casos agudos, porém resultados falsos-positivos foram observados com soros de pacientes com outras doenças como leishmaniose, paracoccidiose e toxoplasmose aguda ( $c f$. Ferreira, 1992). Além disso seu alto custo é alto.

A imunofluorescência indireta é um dos testes de referência na sorologia da fase crônica da doença de Chagas, sendo também capaz de detectar anticorpos IgM na fase aguda (cf. Ferteira, 1992). Nesse caso, são urilizadas formas epimastigotas fixadas em lâminas, incubadas com o soro teste, lavadas e tratadas com um anticorpo anti-IgG ou antiIgM, conjugado à fluoresceína. As amostras de sangue também podem ser coletadas e sêcas em papel de filtro para, posteriormente se eluir e testar a reatividade dos anticorpos (Souza \& Carnargo, 1966). Nesse sistema, os filtros podem ser mantidos por até um mês à temperatura ambiente sem alteração da reatividade. A imunofluorescència apresenta uma 
alta concordância com a reação de fixação do complemento, entretanto verifica-se uma reatividade cruzada com soros de pacientes com leishmanose, tuberculose e lepra (Camargo, 1966). Buscando diminuir a reatividade cruzada entre $T$. cruzi e Leishmania, Camargo \& Rebonato (1969) verificaram que a absorção de soros de pacientes com doença de Chagas e leishmaniose com antígenos de Leishmania e T. cruzi, respectivamente, reduzia a reatividade heteróloga, sem afetar a sensibilidade de detecção. A partir desse resultado. propuseram um método de inibição da imunofluorescência inespecífica, pela adição de extratos heterólogos aos soros. Entretanto, esta abordagem é bastante trabalhosa nāo sendo adotada como rotina em laboratórios clínicos e bancos de sangue.

Visando a padronização de um teste de referência para o diagnóstico da doença de Chagas, Camargo et al. (1977) compararam os testes de fixação de complemento, imunofluorescência indireta, hemaglutinação e floculação, utilizando um total de 3.624 soros das regiôes de Mambai - GO e São Paulo. Os autores verificaram que $97 \%$ dos soros apresentaram concordância total entre os quatro testes; $0,8 \%$ dos soros, considerados positivos, reagiram em 3 testes e 1,8\% dos soros, considerados negativos, somente foram positivos em um dos testes. Um total de $0,4 \%$ dos soros tiveram reatividade com apenas dois testes, sendo considerados duvidosos. Esse resultado demonstra que, utilizando condições padronizadas, é possível obter uma aita concordância entre os diferentes testes de diagnóstico.

Outro teste utilizado em laboratórios clínicos é o ELISA, preparado a partir de annigenos de formas epimastigotas adsorvidos nos poços de microplacas. Sua grande vantagem é permitir a realização de múltiplos exames e uma leitura automática. Ferreira et al. (1991) padronizaram um ensaio de ELISA utilizando microplacas de 96 poços sensibilizadas com um extrato rotal de T. cruzi (bioELISA-cruzi - Biolab Diagnóstica S/A). 0 reste foi avaliado com 219 soros com diagnóstico clínico de doença de Chagas e 104 de outras doenças. Além disso, comparou-se o teste de ELISA com os testes de hemaglutinação e imunofluorescência, utilizando 1.325 soros. A sensibjlidade observada foi superior a 99,5\%. No entanto, em um toral de 39 casos de leishmaniose, 15 soros reagiram positivamente. Um outro teste de ELISA comercial, desenvolvido pelos laboratórios Abbott (Pan et al., 1992), foi avaliado com 1.392 amostras de soros do Brasil e Argentina. Os autores afirmam que o teste apresentou $100 \%$ de sensibilidade e especificidade, no entanto a natureza do antígeno empregado nāo é revelada.

Com exceção do teste acima, todos os outros testes sorológicos citados apresentam uma sensibilidade inferior a $100 \%$. Isso ocorre porque medem os anticorpos dirigidos contra o parasita, o que depende da resposta individual de cada paciente. Além disso, diferentes cepas poderiam induzir diferentes especificidades nas populaçōes de anticorpos. Um dos maiores problemas enfrentados nesses testes é o diagnóstico correto para soros que apresentam uma reatividade muito próxima do valor de corte ("cut off") previamente 
esrabelecido. Para bancos de sangue, onde se requer uma sensibilidade máxima, soros com diagnóstico duvidoso seriam automaticamente descartados. No entanto, também nesse caso, a execução de dois a três testes sorológicos distintos é recomendada.

Quando se considera o diagnóstico laboratorial de um paciente, o maior número possivel de parâmetros deve ser avaliado antes de lhe atribuir um resultado positivo. São relatados casos em que hả resultados sorológicos duvidosos para um ou mais testes, enquanto os sinais clínicos apontam para a existência de uma infecção chagásica. Esse aspecto deve ser especialmente considerado devido às graves conseqüências individuais e sociais que tal diagnóstico pode acarretar para o paciente. A existência de reações falsopositivas pode complicar essa situaçāo, notadamente em áreas geográficas endêmicas para T. rangeli e Leishmania, dois prorozoários que compartilham epitopos com $T$, cruzi (Afchain et al., 1979). Conforme foi exposto acima, os diferentes testes que empregam extratos totais de T. cruzi apresentam reaçóes cruzadas com soros de pacientes com leishmaniose (Muniz e Freitas, 1944; Neals \& Miles, 1970; Camargo, 1966; Camargo \& Rebonato, 1969; Ferreira et al. 1991). No caso de $T$, rangeli a situação é similar (Guhl et al, 1985; Hudson et al, 1988). Deve ser lembrado que $T$. cruzi e $T$. rangeli compartilham algumas áreas geográficas comuns na América Latina, apresentando a mesma gama de hospedeiros e, freqüentemente, os mesmos vetores.

Guhl et al. (1985) verificaräm que soros de camundongo anti-T. rangeli apresentam uma reatividade cruzada significativa com $T$. cruzi em imunofluorescência, mas não em ELISA com lisado de epimastigotas. Em ensaios realizados com soros humanos de regiōes endêmicas para os dois parasitas, foi verificado que a reatividade cruzada rende a ser unilateral, isto é, os soros anti- $T$. cruzi reconhecem $T$. rangeli com maior intensidade do que os soros anti- $T$. rangeli reconhecem $T$. cruzi. Utilizando os testes de ELISA $e$ imunofluorescência em conjunto, os autores foram capazes de discemir os soros de pacientes com $T$. cruzi, $T$. rangeli ou com infecções mistas. Foi observado também que a GP90, uma glicoproteína de formas epimastigotas de $T$. cruzi, é específica para soros anti- $T$. cruzi em ensaios de ELISA. Hudson et al. (1988), utilizando ensaios de ELISA e imunofluorescência, observaram em soros de regiões endêmicas da Colômbia que 37\% dos soros positivos para $T$. cruzi tinham anticorpos contra $T$. rangeli, o que pode significar uma reatividade cruzada ou uma infecção mista. Acredita-se que $T$. rangeli nāo seja patogênico para o homem, mas seu papel em infecções mistas ainda é desconhecido. De fato, camundongos imunizados com $T$. rangeli e infectados com $T$. cruzi apresentam uma parasitemia e taxa de mortalidade menores do que um grupo não imunizado (Basso et al., 1991). Esse resultado sugere que infecções mistas poderiarn levar a manifestações mais brandas da doença de Chagas (Guhl et al, 1987). Essa hipótese, contudo, deve ser testada através de estudos longitudinais em populaçōes de áreas endêmicas comuns aos dois parasitas e comparada com estudos em áreas afetadas só pelo T. cruzi. 
Os testes de diagnóstico sorológico da doença de Chagas disponíveis atualmente no mercado, apesar de individualmente não aringirem 100\% de sensibilidade podem, se usados conjuntamente, atingir marcas próximas desse valor e atender ao requerimento de bancos de sangue, onde a máxima sensibilidade é um fator primordial. Subsistem, entretanto, problemas referentes à especificidade, especialmente quanto a $T$. rangeli e Leishmania. Como esses parasitas compartilham uma grande porcentagem de seus epitopos com $\tau$. cruzi, o uso de extratos totais do parasita como antigeno em testes sorológicos é incompatível com a obtenção de especificidades altas. Em funçāo disso, vários laboratórios procuraram estabelecer restes diagnósticos empregando antígenos definidos, seja diretamente purificados do $T$. cruzi, seja expressos em sistemas bacterianos, através de técnicas de DNA recombinante.

\subsubsection{Antigenos purificados e recombinantes}

Conforme discurido acima, a urilização de testes que empregam extratos totais do parasita podem ser satisfarórios em condições nas quais se exige a máxima sensibilidade, como em bancos de sangue. Nesse caso costuma-se reduzir os valores de limiar de rearividade ("cut off"), ainda que se obtenha uma menor especificidade, uma vez que e muito importante rejeitar a amostra de sangue suspeita. Estudos epidemiológicos requerem testes muito sensíveis e específicos e que também sejam baratos, práticos, de execução simples e que permitam o transporte da amostra do campo até o laboratório (Luquetti, 1990). Outra situação diz respeito à confirmação diagnóstica de um paciente clinicamente suspeito em que, ao lado de uma alta sensibilidade, requer-se também uma alta especificidade em virtude das implicações sociais que este diagnóstico pode acarretar para o paciente. Finalmente, o acompanhamento de pacientes ratados com quimioterápicos talvez seja a mais desafiadora siruação de diagnóstico, uma vez que exige sensibilidade e especificidade muito altas, que atualmente só podem ser obtidas pelo uso conjunto de vários testes.

A utilização de testes compostos de antígenos definidos e puros visa atender o requerimento de alta especificidade. Embora alguns antígenos de $T$. cruzi testados para o diagnóstico sorológico da doença de Chagas em laboratório tenham apresentado resultados promissores (Dragon et al., 1985; Gazzinelli et al., 1993), sua aplicação em larga escala apresenta dificuldades técnicas. Esses antígenos freqüentemente estão presentes em quantidades muito reduzidas no parasita, o que dificulta e encarece sua obtençāo. A purificaçāo de antígenos da forma tripomastigota exige o cultivo dessa forma infectante que, além do perigo da manipulação, requer uma cultura de células, o que torna esta abordagem inviável para grande parte dos laboratórios de regiōes menos desenvolvidas. 
O surgimento das técnicas de clonagem e expressão de antigenos em sistemas heterólogos abriu uma nova perspectiva para os testes sorológicos. A utilizaçāo de antígenos recombinantes puros poderia levar ao desenvolvimento de testes tão ou mais sensiveis que os convencionais, aliando uma maior especificidade. Além disso, sendo o antígeno produzido em bactérias em larga escala, não exige o cultivo do parasita. Vários grupos iniciaram a clonagem de antigenos $T$. cruzi a partir da segunda metade da década de 80 (Peterson et al., 1986; Ibañez et al., 1987; Beard et al., 1988; Hoft et al., 1989; Lafaille et al., 1989; Takle et al., 1989). Observou-se que uma fração significativa dos antígenos clonados apresentava como característica a presença de repetiçōes seriadas de aminoácidos (Frasch et al, 1991).

Várias proteínas clonadas revelaram alta homologia entre si, caracterizando famílias multigênicas, como foi observado com a neuraminidase/trans-sialidase (Pereira et al., 199l; Kahn et al., 1991; Tackle \& Cross, 1991; Parodi et al., 1992; Uemura et al., 1992; Pollevick et al., 1993; Ruef \& Manning, 1993). A neuraminidase de T. cruzi apresenta um domínio enzimaticamente ativo e outro composto de repetiçōes seriadas sem atividade enzimática, mas imunodomínante (Cazzulo \& Frasch, 1992; Campetella et al., 1994). Situaçāo semelhante ocorre com a cruzipaína, uma cisteína protease codificada por uma familia de genes polimórficos (Eakin et al., 1992; Campetella et al, 1992; Cazzulo \& Frasch, 1992) cuja proteína havia sido previamente caracterizada por Scharfstein et al. (1986) como GP57/51 e por Cazzulo et al. (1989).

Um total de 9 clones recombinantes foi isolado e caracterizado pelo grupo do Dr. Carlos Frasch (Ibañez et al, 1987; Ibañez et al, 1988). Todos os antígenos demonstraram a presença de repetições seriadas de diferentes tamanhos. O clone \#7 corresponde a um antigeno polimórfico de 160 a $200 \mathrm{kDa}$, que é liberado para o meio de cultura pelo parasita. Quando os autores testaram a reatividade preferencial dos diferentes antígenos clonados com soros de pacientes em fase crônica e aguda, foi verificado que o antígeno \#7 era majoritariamente reconhecido por soros agudos (Affranchino et al., 1989). Devido a essas duas características, esse antigeno foi denominado SAPA ("shed acute-phase antigen"). 0 gene correspondente foi isolado e completamente seqüenciado (Pollevick et al., 1991), apresentando alta homologia com a neuraminidase descrita por Pereira et al., (1991).

O diagnóstico sorológico da fase aguda é dificultado pela baixa concentração de anticorpos da classe IgG. A detecção de IgM pode ser realizada alternativamente. No caso da transmissão congênita há a passagem trans-placentária de anticorpos das classes IgG, IgE e IgA, mas nāo de IgM. Desta forma, o diagnóstico sorológico em recém-nascidos pode ser efetuado investigando-se a especificidade de anticorpos da classe anti-IgM. Para a doença de Chagas a sensibilidade de detecção nestes casos é baixa. Reyes et al. (1990) testaram 10 soros de recém-nascidos infectados e observaram que 6 desses soros foram positivos no ensaio de ELISA e negativos na imunofluorescência indireta, utilizando conjugados anti-IgM. 
Além disso, ao contrário do que se supunha, as māes que geraram crianças infectadas apresentaram reatividade com anticorpos da classe IgM, enquanto que aquelas que geraram crianças sadias não apresentaram reatividade de anticorpos IgM. Segundo os autores, esse resultado surpreendente poderia talvez ser atribuido a uma estimulação não específica do sistema imune materno em função da infecção fetal. Quando Reyes et al. (1990) testaram os soros dos recém-nascidos e das māes frente a diferentes antigenos recombinantes, foram evidenciadas diferenças específicas de reatividade entre os dois grupos. A análise de anticorpos IgG e IgM em 10 crianças infectadas demonstrou que 8 delas apresentavam reaçōes específicas aos antigenos recombinantes de $T$. cruzi. O melhor antigeno de detecçāo foi o SAPA (Affranchino et al., 1989), que reagiu com 7 dos soros de recém-nascidos (tanto por $\operatorname{IgM}$ como por $\lg G$ ), mas nāo com os soros das respectivas māes. Esse resultado é particularmente interessante porque demonstra que poderia haver a produção de $\lg G$ específica pelo feto ainda na infecçāo uterina. Os autores propõem que a utilização de antígenos recombinantes poderia discemir especificamente as IgGs provenientes da mãe daquelas produzidas pela criança infectada.

Affranchino et al. (1989) testaram a reatividade preferencial dos diferentes antigenos clonados frente a soros da fase aguda e crônica. O antígeno \#2 demonstrou ser amplamente reconhecido por soros de pacientes na fase crônica da doença. $O$ gene correspondente foi totalmente seqüenciado (Buschiazzo et al., 1992) e nāo revelou homologia com nenhuma proteina conhecida. O antígeno em questão apresenta no parasíta um peso molecular de 160/140 kDa. Várias hipóteses foram levantadas para explicar a reatividade diferencial de antígenos clonados durante a fase aguda (SAPA) ou fase crônica (antígeno \#2) da doença de Chagas (cf. Leguizamon et al., 1991). Esta reatividade poderia ser decortente da existência de sub-populaçòes de parasitas, selecionadas pela resposta imune do hospedeiro; ou de alteraçòes na expressão dos antígenos pelo parasita ao longo da infecçāo. Para restar essas hipóteses, Leguizamon et al. (1991) infectaram camundongos e analisaram os anticorpos induzidos na infecção, bem como os antígenos expressos pelos parasitas ao longo da infecção. Os autores verificaram que os parasitas induzem preferencialmente a produção de anticorpos dirigidos contra o antígeno SAPA na fase aguda, mas não contra os antígenos \#1, \#2, \#13, \#30 e \#36. Por outro lado, foi verificado que os parasitas circulantes expressam todos esses antigenos. Conclui-se que as formas tripomastigotas expressam simultaneamente antigenos que são marcadores das fases aguda e crônica da doença de Chagas.

Levin et al. (1989) também isolaram vários clones recombinantes denominados JL1, JL-5, JL-7, JL-8 e JL-9. Os clones JL-7, JL-8 e JL-9 são homólogos aos antígenos \#1, \#30 e \#36, respectivamente, descritos por Ibañez et al. (1988). O antígeno JL-5 se mostrou promissor para o diagnóstico de pacientes com a forma cardíaca da doença de Chagas. De fato foi demonstrado que este antígeno apresenta homologia com a porção carboxi-terminal 
da proteína P ribossomal humana. Essa seqüência corresponde ao epitopo de reatividade cruzada determinado em casos de lúpus eritematoso sistêmico. Um pepridio de 13 resíduos, denominado R-13, que contém esse epitopo, foi utilizado em ensaios de ELISA e reconhecido por $57 \%$ dos soros de chagásicos e $12 \%$ dos soros de pacientes com lúpus (Levin et al., 1990\}. Esse epitopo pode, portanto, ser um marcador da presença de autoanticorpos, os quais podem ter um papel na patogênese da forma cardíaca da doença de Chagas. Outras proteínas $P$ ribossomais também foram clonadas por esse grupo (Levin et al., 1993) e por Skeiky et al. (1993), que também observaram a presença de reatividade cruzada entre anticorpos contra as proteínas $P$ ribossomais de $T$. cruzi e proteinas $P$ humanas.

O grupo do Dr. Samuel Goldenberg (FIOCRUZ - RJ) relatou o isolamento e caracterização de dois antígenos de $T$. cruzi (Lafaille et al, 1989), denominados CRA ("cytoplasmic repetitive antigen") e FRA ("flagellar repetitive antigen"). CRA corresponde aos antigenos \#30 descrito por lbañez et al. (1988) e JL-8 de Levin et al. (1989), enquanto FRA é homólogo ao antígeno \# le lbañez et al. (1988) e 3L-7 de Levin et al. (1989). Ambos os genes apresentam repetiçōes seriadas, estão presentes em diferentes cepas do parasita e são polimórficos. Os dois antígenos foram subclonados no vetor pMSgr ll l e expressos em fusāo com $\beta$-galactosidase. Após clivagem com a protease Fator $X a$, os polipeptidios foram testados em conjunto, no mesmo poço, em ensaios de ELISA (Almeida et al., 1990; Krieger et al, 1992). O teste foi realizado com 221 soros de chagásicos, 193 soros normais de áreas endêmicas, 49 soros negativos de bancos de sangue e 80 soros de pacientes com outras doenças. O uso combinado dos antigenos CRA e FRA resultou em uma sensibilidade e especificidade de 100\%. Em comparaçào, um teste paralelo de ELISA, utilizando um extrato citossólíco de parasitas, apresentou 12 resultados falso-positivos.

No laboratório do Dr. Franco da Silveira (Escola Paulista de Medicina) foram isolados dois antigenos com potencial de diagnóstico denominados Al3 (Paranhos et al., 1990) e H49 (Cotrim et al., 1990). O antigeno H49 é homólogo aos antígenos FRA (Lafaille et al., 1989), JL-7 (Levin et al., 1989) e \#l (Ibañez et al., 1988), descritos previamente por outros grupos. O antigeno correspondente a Al3 tem $230 \mathrm{kDa}$ e é encontrado em formas amastigotas e nipomastigotas, mas não em epimastigotas. Em ensaios de diagnóstico esse antígeno foi reconhecido por $91 \%$ dos soros de pacientes chagásicos agudos e crônicos (Franco da Silveira et al., 1990). Não foram observadas reaçōes inespecificas com soros de pacientes com outras afecçōes. O antígeno H49 obteve uma sensibilidade ainda melhor, sendo reconhecido por $99 \%$ dos soros de pacientes crônicos. Esse antígeno foi posteriormente subclonado no vetor pGEX e expresso. A proteína de fusão foi clivada com Fator Xa e o polipeptídio testado em ensaio de ELISA (Paranhos-Bacalla et al., 1994) com 296 soros, incluindo pacientes chagásicos em diferentes fases da doença e pacientes com outras afecções. O desempenho do antígeno foi inferior ao obtido anteriormente, 
apresentando sensibilidade de $84 \%$ com pacientes crônicos, $58 \%$ corn agudos e $56 \%$ com soros de casos congênitos. Entretanto, a especificidade do antígeno foi de $100 \%$ indicando que pode ser utilizado em conjunto com outros antígenos para o desenvolvimento de um reste sensivel e altamente específico para a doença de Chagas.

Nosso grupo também clonou e expressou dois antigenos recombinantes denominados B12 e B13, conforme será relatado no presente trabalho. O antígeno B13, homólogo ao clone \#2 de Ibañez et al. (1988), apresentou um bom desempenho, com 97\% de sensibilidade e especificidade (Gruber \& Zingales, 1993). O antigeno B12, que não apresenta homologia com nenhum dos outros annigenos clonados, mostrou uma sensibilidade de $83 \%$ e especificidade de 78\% (Zingales et al., 1990; Gruber \& Zingales, 1993).

Em 1990 a Organização Mundial da Saúde decidiu testar a reatividade de várias proteínas recombinantes e antígenos purificados de T. cruzi (Moncayo \& Luquetti, 1990). Para isso, escolheu um laboratório de referência em Goiás, o qual selecionou um painel de 50 soros, incluindo pacientes chagásicos, controles normais e pacientes com outras parasitoses (Luquetti, 1990). Esses soros foram codificados e distribuidos a um total de nove laboratórios da Argentina, Brasil, Colômbia e Estados Unidos. Cada laboratório teve a liberdade de padronizar um ensaio de sua escolha para testar seus antigenos. A análise estatística fol feita utilizando-se o indice ( $k$ ) kappa (Cohen, 1960). Os antígenos que apresentaram os melhores desempenhos foram o CRA $(k=1,0)$; B13 ( $x=0.96)$, H49 $(x=0,92)$, JL-7 $(x=0,88)$ e Al3 $(x=0,88)$. Esse resultado demonstrou a viabilidade de se empregar antigenos puros, especialmente recombinantes, para a composiçāo de testes diagnósticos para a doença de Chagas.

Os resultados promissores revelados por esse estudo multicêntrico encorajaram alguns grupos a elaborar testes de ELISA empregando como antigenos, peptidios sintéticos derivados das seqüências dos antígenos recombinantes (Vergara et al., 1991; Vergara et al, 1992; Burns et al., 1992; Peralta et al., 1994). Os resultados obtidos por esses grupos serão melhor discutidos no item 4.2 .

\subsection{Formas de controle da doença de Chagas}

\section{3.l. Eliminação do vetor}

A inexistência de uma vacina e os resultados ainda preliminares sobre a eficiência da quimioterapia torna a eliminação dos vetores transmissores um dos principais campos de atuação no controle da doença de Chagas. Preconiza-se que os programas de erradicação do vetor tenham três fases de atuação: preparatória, de ataque e de vigilância (Días, 1987; Schofield, 1985). Na fase preparatória faz-se um mapeamento das regiōes atingidas, uma 
amostragem de barbeiros domiciliados e de habitats peri-domiciliares, avaliação dos custos e de recursos humanos e materiais a serem empregados. Na fase de ataque procede-se à borrifação de todas as casas, infestadas ou não, com uma nova borrifação das infestadas, após 3 a 6 meses. Essa fase é mantida com avaliações periódicas e borrifações das casas ainda infestadas, até reduzir a infestação da região a menos de $5 \%$ e não haver mais casas infestadas. Na fase de vigilância faz-se uma amostragem periódica das casas por pessoal especializado e por equipes voluntárias locais. Além disso, instalam-se postos voluntários de coordenação de colera, denúncias e identificação de possíveis reinfestações (cf. Dias, 1987).

O programa brasileiro, realizado de 1984 a 1986 conseguiu reduzir o número de municípios afetados de 2.234 para 186 (74\% de redução da área endêmica) e, em 1987, 23\% dos municipios já haviam entrado na fase de vigilância (cf. Dias, 1987). No Brasil o BHC (hexacloreto de benzeno) foi utilizado em larga escala no programa de erradicação do vetor, sendo posteriormente substituído por malathion e piretróides. Os piretróides, por serem menos irritantes e inodoros e por apresentar maior efeito residual são atualmente mais recomendados. Embora essas substâncias sejam mais caras, as menores doses empregadas equiparam o custo final com o do BHC (cf. Dias, 1987).

\subsubsection{Quimiorerapia}

Apesar da doença de Chagas ter sido descoberta há mais de oito décadas, ainda não existem quimioterápicos eficientes para o tratamento e cura de pacientes, especialmente daqueles na fase crônica. Em parte isso se deve à grande resistência do $T$. cruzi aos agentes quimioterápicos utilizados em outras doenças parasitárias (cf. Tanowitz et al., 1992). 0 grande desafio da quimioterapia é a destruição dos parasitas intracelulares sem efeitos prejudiciais às próprias células do hospedeiro. Vários compostos químicos foram testados ao longos dos anos e entre eles, o nifurtimox (Lampit - Bayer) e o benzonidazol (Rochagan ${ }^{*}$ - Roche) são os que apresentaram os melhores efeitos. Infecçōes acidenrais em laboratórios e alguns casos agudos foram tratados com sucesso. Essas drogas diminuem a severidade da fase aguda, entretanto na fase crônica seus efeitos sāo ainda objeto de especulação. Além disso, esses quimioterápicos têm de ser utilizados por longos periodos de rempo e apresentam efeitos colaterais intensos, o que inviabiliza seu uso em larga escala. Há também relatos de uma ação tumorigênica em experimentos realizados em coelhos (Teixeira et al., 1990a; 1990b).

As pesquisas atuais na área de quimioterapia estāo voltadas para a caracterização de enzimas de $T$. cruzi, especialmente quanto ao seu mecanismo de açāo e conformaçāo do sitio ativo. O objetivo é desenvolver novas drogas especialmente desenhadas para uma inibição específica das enzimas de $T$. cruzi, sem apresentar efeitos nas enzimas 
correspondentes do hospedeiro. Uma grande dificuldade que existe no desenvolvimento de novas drogas é a ausência de critérios de avaliação da cura. Embora na fase aguda possa se acompanhar a parasitemia, não há como se determinar com precisão uma cura parasitológica. Esse aspecto é particularmente mais grave na fase crônica, onde naturalmente há uma baixa parasitemia.

Krettii \& Brener (1982) relataram que camundongos infectados com parasitas vivos desenvolvem anticorpos denominados "líticos", capazes de induzir a lise mediada por complemento. Por outro lado, animais imunizados com parasitas fixados somente produzem anticorpos detectáveis por sorologia convencional, sem capacidade "protetora". Pelo fato de os anticorpos "protetores" ou "líticos" somente serem produzidos sob a indução de parasitas vivos, Kretrli et al. (1982) sugeriram que o desaparecimento de anticorpos "líticos" poderia ser urilizado como crisério de cura dos pacientes. Uma crítica que pode ser feita a essa conclusão é de que a cura não deveria ser atribuida por um método sorológico, mas por diagnóstico parasitológico. No entanto, os métodos de deteç̧ăo do parasita utilizados (xenodiagnóstico e hemocultura) não são suficientemente sensiveis para fomecer uma evidência incontestável da ausência de parasitas no paciente. O aprimoramento dos critérios de cura parasirólogica é condição essencial para uma avaliação segura da eficácia de novas drogas a serem implementadas na rerapia da doença de Chagas.

\subsubsection{Vacinação}

Uma vacina considerada ideal para a doença de Chagas deve apresentar várias caracteristicas desejảveis. Primeiramente essa vacina deveria promover uma proteçăo total, impedindo a instalação de uma parasitemia e a conseqüente fase aguda da doença. A simples redução da severidade da fase aguda não seria aceitável porque poderia permitir o estabelecimento de uma fase crônica com as respectivas manifestaçōes clínicas (Brener \& Camargo, 1982; Brener, 1986). Essa vacina deveria ser, por questōes de segurança, estéril. Além disso, nāo poderia induzir respostas autoimunes ou imunossupressoras. Várias composiçōes de vacinas já foram testadas, incluindo parasitas vivos atenuados e proliferantes, parasitas vivos nào proliferantes, parasiras mortos, fraçōes celulares ou homogenaros e antigenos puros (cf. Brener \& Camargo, 1982). Embora várias dessas vacinas tivessem conferido diferentes graus de proteção a desafios com parasitas vivos, seus efeitos em termos de geraçāo de respostas autoimunes e possiveis danos teciduais são desconhecidos. A utilizaçāo de vacinas compostas de antigenos definidos poderia gerar melhores resultados. Nesse sentido, antigenos de superfície, envolvidos nos processos de adesão e interiorização do parasita na célula do hospedeiro, poderiam ser mais promissores. Entretanto, alguns resultados têm demonstrado que somente parasitas vivos podem induzir a produçāo de anticorpos protetores que determinam a lise mediada por 
complemento (Krettli \& Brener, 1982). Os anticorpos induzidos por antigenos puros ou por parasitas mortos nāo estariam associados com a resistência do hospedeiro.

O desenvolvimento de uma vacina eficiente para a doença de Chagas é, possivelmente, um objetivo muito distante a ser alcançado. Nesse sentido, faz-se necessário conhecer o processo de interiorização do parasita na célula do hospedeiro, além da compreensão do conjunto dos mecanismos imunológicos envolvidos no reconhecimento e destruiçāo das células do parasita, bem como na quebra de tolerância induzida por alguns dos antígenos parasitários.

Finalmente, qualquer vacina desenvolvida terá de ser testada e, além de macacos Rhesus, não há bons modelos animais disponiveis. Um teste em voluntários humanos ė extremamente complicado, uma vez que a doença de Chagas pode demorar até 30 anos para ter manifestações clínicas definidas. Alêm disto há consideraçōes éticas importantes na medida em que esses voluntários deveriam ser expostos em áreas de risco juntamente com grupos controle năo protegidos (cf. Brener \& Camargo, 1982), além do fato de que não existem quimioterápicos de eficiência comprovada.

\subsection{Aspectos da biologia molecular do Trypanosoma cruzi}

\subsubsection{Conteúdo de DNA, ploidia e cariótipo}

O conteúdo de DNA do T. cruzi foi medido por reassociação cinética de DNA:DNA por Castro et al. (1981), resultando em $1,53 \times 10^{8} \mathrm{pb}$, correspondente a uma massa de 173 fg. Lanar et al. (1981), utilizando cinética de reassociaçāo de DNA:DNA e microespectrofluorometria, obtiveram um valor de $280 \mathrm{fg}$ ou $2,5 \times 10^{8} \mathrm{pb}$. Comparando as complexidades química e cinética, os dois grupos encontraram valores compatíveis com uma diploidia. Kooy et al. (1989) também realizaram mediçōes, utilizando microfluorometria direta com o corante pararosanilina, e comparam os conteúdos de DNA das cepas $Y$ e Esmeraldo. Os valores encontrados foram $125 \mathrm{fg}\left(1,1 \times 10^{8} \mathrm{pb}\right)$ para a cepa $Y$ e $200 \mathrm{fg}\left(1,8 \times 10^{8} \mathrm{pb}\right)$ para a cepa Esmeraldo. Esses resultados, além de serem semelhantes aos obtidos por Castro et al. (1981) e Lanar et al. (1981), demonstram haver uma heterogeneidade intraespecífica no conteúdo de DNA do $T$. cruzi.

Os dados de diploidia obtidos pelos trabalhos acima estão de acordo com os resultados obtidos por Gibson et al. (1985), que analisaram a distribuiçāo cromossômica e RFLPs de "housekeeping genes" de trípanossomas africanos, bem como com as conclusōes da análise de zimodemas de $T$. cnuzi (Tibayrenc et al. 1986). Outro dado em favor da diploidia foi obtido por Henriksson et al. (1990), que verificaram que muitas sondas clonadas hibridizavam com um par de fragmentos de restrição em diferentes cepas, sugerindo que elas deveriam corresponder a dois alelos. Para uma das seqüências clonadas 
foram apresentados os mapas de restrição de regiões homólogas e hanqueadoras nos dois alelos, os quais tinham uma pequena variaçāo de tamanho. Além disso foi demonstrado, em uma eletroforese de campo pulsado em duas dimensões, que cada uma das bandas observadas em Southem blot era derivada de cromossomos distintos, que deveriam ser homólogos.

A análise do cariótipo de $T$. cruzi não pode ser feita por microscopia ótica uma vez que os cromossomos não se condensam em nenhum estágio do ciclo celular. O estudo do cariótipo de $T$. cruzi tem sido feito através de eletroforese de campo pulsado (PFGE). Os vários grupos que analisaram o cariótipo de $T$. cruzi, apesar das diferentes cepas e sistemas de PFGE empregados, obtiveram resultados bastante semelhantes quanto ao número e tamanho dos cromossomos de $T$. cruzi. Foi observada a presença de pelo menos 20 bandas cromossomais, variando na faixa de 0,3 a 3,5 Mb (Gibson \& Miles, 1986; Engman et al., 1987; Henriksson et al, 1990; Aymerich \& Goldenberg, 1989; Caro et al., 1994). Com exceção de Engman et al. (1987), que evidenciaram cromossomos de 50-150 kb, não foi descrita a presença de minicromossomos em $T$. cruzi. A discrepância do resultado desse grupo pode ser devida ao sistema de PFGE urilizado, ao número de parasitas empregados ou a migrações anômalas de cromossomos.

Outro aspecto verificado no cariótipo de $T$. cruzi è a heterogeneidade da localizaçăo cromossômica dos genes, bem como do tamanho dos cromossomos entre as diferentes cepas (Gibson \& Miles, 1986; Engman et al., 1987; Henriksson et al., 1990; Aymerich \& Goldenberg, 1989; Cano et al, 1994). Esse resultado está de acordo com a teoria de uma evoluçăo clonal remota seguida de uma evolução independente dos múltiplos clones (Tibayrenc et al., 1986; Tibayrenc \& Ayala, 1987), aliada a uma grande plasticidade do genoma.

\subsubsection{DNA de cinetoplasto (kDNA)}

O cinetoplasto representa uma estrutura $\mathrm{cm}$ forma de disco, perpendicular e próxima ao corpo basal do flagelo, comum aos membros da ordem Kinetoplastida. Essa estrutura é composta de milhares de círculos de DNA concatenados dentro da única mitocôndria da célula, formando uma malha que representa cerca de 10-25\% do genoma do parasita (cf. Englund, 1982). Cerca de 95\% da malha è composta por cerca 5.000-10.000 minicírculos de $700-2.500 \mathrm{pb}(1,42 \mathrm{~kb}$ em $T$. cruzi) e por 25 a 50 maxicírculos de $20-38 \mathrm{~kb}$ (36 kb em $T$. cruzi). Os maxicirculos contém genes de rRNA, e das proteínas mitocondriais

citocromo b, citocromo oxidase e NADH desidrogenase (Clayton, 1988), sendo portanto funcionalmente análogos a outros DNAs mitocondriais (Stuart, 1983). Os minicírculos de $T$. cruzi possuem quatro regiões de 120 pb repetidas e simetricamente arranjadas em ângulos de $90^{\circ}$, intercaladas por quatro regiōes não repetidas e variảveis (Degrave et al., 1988). Até 
há alguns anos atrás a funçāo dos minicírculos era completamente desconhecida, mas conforme será discutido no item 1.4.4, sabe-se atualmente que eles participam do processo de editoração de RNA. As razões que privilegiaram a manutenção de uma estrutura em malha tāo organizada no cinetoplasto ao longo da evolução não são conhecidas. Borst (1991) propõe que a malha serviria como um dispositivo primitivo de divisão mitótica que reduziria a segregaçāo entre maxicírculos e minicírculos.

\subsection{3. "Trans-splicing"}

Os membros da ordem Kinetoplastida apresentam outros aspectos bastante peculiares, especialmente quanto ao processamento dos transcritos. A comparação das seqüências de cDNAs e de um gene codificador de VSG ("variant surface glycoproteins") em T. brucei demonstrou a existência de uma região de 35 nucleotidios, denominada seqüência líder (SL) ou mini-exon, presente na extremidade 5' terminal do mRNA, mas ausente no respectivo gene (Van der Ploeg et al., 1982). Posteriormente foi observado que essa seqüência estava presente em outros mRNAs de VSGs (Boothroyd \& Cross, 1982). A presença ubíqua do mini-exon em mRNAs de tripanossomanidios que não sofrem variação antigênica (De Lange et al., 1984a; Nelson et al., 1984) descartou a idéia de que o mini-exon ou seus genes pudessem estar associados à regulaçāo da rranscriçāo de genes de VSG (De Lange et al., 1983).

Aparentemente todos os mRNAs maduros apresentam a seqüência líder de 35-39 bases na sua extremidade 5' terminal (De Lange et al., 1984b; Parsons et al., 1984; Walder et al., 1986). Os transcritos dos genes de SL-RNA ("spliced leader RNA") ou medRNA ("miniexon derived RNA") foram identificados em vários tripanossomatidios. Em T. brucei o transcrito apresenta cerca de 140 bases (Milhausen et al., 1984; Campbell et al., 1984), enquanto em $T$, cruzi o SL-RNA apresenta 105-110 bases (Milhausen et al., 1984; McCarthyBurke et al., 1989). Os SL-RNAs, assim como os mRNAs, possuem um capacete ("cap") composto de 7-metilguanosina (Lenardo et al., 1985; Laird et al., 1985) e quatro bases modificadas (Freistadt et al., 1987). Admite-se que o SL-RNA tenha como uma de suas funções atuar como uma estrutura doadora de capacete, além de estar possivelmente acoplado ao processo de poliadenilação dos mRNAs (LeBowitz et al., 1993)

Os genes de SL-RNA estão presentes em cerca de 200 cópias, sendo a maior parte delas arranjadas seriadamente em alguns blocos e outras espalhadas no genoma (De Lange et al., 1983; Nelson et al., 1983). A unidade repetitiva apresenta cerca de 1,35 kb em $T$. brucei (De lange et al., 1983) e 0,6 kb em T. cruzi (McCarthy-Burke et al., 1989). A região dos genes correspondente ao SL-RNA é mais conservada nas diferentes espécies do que a regiāo não transcrita (McCarthy-Burke et al., 1989). 
A descoberta que o mini-exon está presente em muitos mRNAs e que, por sua vez, os genes de SL-RNA estão contidos em blocos, levou à idéia de que a transcrição dos genes codificadores de proteínas deveria ser descontínua (De Lange et al., 1984). Outro indício a favor da transcrição descontínua veio a partir dos dados de inibição de transcríção por $\alpha$ amanitina. Foi verificado que os genes de SL-RNA são um pouco mais resistentes à $\alpha$ amanitina do que os genes de proteinas, mas devem ser transcritos pela RNA polimerase II. Entretanto, os genes de VSG são resistentes a $\alpha$-amanitina sugerindo que sua transcrição seja feita pela RNA polimerase I (Kooter \& Borst, 1984; Laird et al., 1985).

A doação do mini-exon ao pré-mRNA pelo SL-RNA ocorre por um mecanismo de "rrans-splicing", ao contrário do que é observado em eucariotos superiores, nos quais ocorre o processamento de introns do mRNA via "cis-splicing". Esse mecanismo foi deduzido a partir da detecção de diferentes intermediários de RNAs semi-processados. Sutton \& Boothroyd (1986) demonstraram a existência de um transcrito livre de 100 bases, homólogo à região 3' terminal do SL-RNA de 140 bases, o qual foi denominado mini-intron, em analogia à seqüência líder ou mini-exon. Durante o processamento de "trans-splicing" o mini-intron se liga ao pré-mRNA via uma ligaçāo 2'-5' fosfodiéster, gerando uma estrutura em forma de $Y$ ou forquilha. Esse intermediário mini-intron/pré-mRNA já é poliadendado. $O$ mini-intron pode ser liberado a partir desse intermediário por mejo de uma enzima desramificadora (Sutton \& Boothroyd, 1986; Murphy et al., 1986; Laird et al, 1987). Ralph et al. (1988) demonstraram a existência de outro intermediário semi-processado, em forma de forquilha, contendo o mini-intron ligado somente ao intron $5^{\prime}$ terminal do mRNA codificador de proténa.

A partir dos dados acima foi possível deduzir a seqüễncia de eventos envolvidos no processo de "trans-splicing". Primeiramente há uma clivagem do SL-RNA no sitio 5' doador de "splicing", liberando o mini-exon (35 bases) e o mini-intron (100 bases). O mini-intron é unido covalentemente, por uma ligação 2'-5' fosfodiéster, ao sitio aceptor 3' do pré-mRNA. Em seguida ocorre a clivagern da extremidade $5^{\prime}$ terminal do pré mRNA, liberando um intermediário em forma de forquilha, o qual contém o mini-intron ligado ao intron do mRNA. Este intermediário pode ser desramificado pela açāo da enzima desramificadora. Finalmente há a junção do mini-exon com o pré-mRNA, gerando o mRNA maduro. $O$ processamento por "trans-splicing" apresenta várias características em comum com o "cissplicing". Os sítios doador e aceptor de "splicing" são definidos pelas seqüências GU e AG, respectivamente. Durante o processamento ocorre a formação de um intermediário contendo uma ligaçāo $2^{\prime}-5^{\prime}$ fosfodiéster. Esse intermediário, contendo o intron removido, apresenta uma estrutura de laço no "cis-splicing" e de forquilha no "trans-splicing".

O processo de "trans-splicing" parece estar relacionado à existência de uma região rica em pirimidinas a montante ("upstream") do sítio 3' aceptor do mRNA (Layden \& Eisen, 1988; Huang \& Van der Ploeg, 1991; de Lafaille et al, 1992) e, além disso, resultados 
experimentais sugerem haver uma relação funcional e temporal entre os eventos de "transsplicing" e poliadenilação de mRNAs (LeBowitz et al., 1993). Estes aspectos serăo melhor discutidos no item 4.7.1.

\subsubsection{Editoração de RNA}

Outro aspecto bastante interessante foi a descoberta da editoração de RNA em transcritos mirocondriais. Até recentemente acreditava-se que somente os maxicírculos continham genes, enquanto que os minicírculos supostamente não eram transcritos. Entreranto esse quadro mudou com a descoberta de que os RNAs de alguns genes mitocondriais sofriam processamentos pós-transcricionais até então desconhecidos. Foi verificado que o gene da subunidade Il da citocromo oxidase (gene coxll) de $T$. brucei continha uma alteração do passo de leitura em relação a genes homólogos de homem e levedura. Essa alteraçāo também era observada em outros tripanossomatidios como Crithidia e Leishmania, entretanto, devido à alta conservaçào desse gene, não parecia tratarse de um pseudogene. A análise do transcrito revelou a adição de quatro uridinas não codificadas no DNA, que restauravam o passo de leitura (Benne et al., 1986). Esse resultado, aliado ao fato de nāo ter sido encontrada uma segunda versão do gene covll, levou à conclusão que deveria haver um processo de editoraçāo do RNA. Shaw et al. (1988) demonstraram que essa editoração ocorria em outros genes como coxllI, MURF2 e MURF3. Um aspecto interessante verificado por esses autores foi que a editoraçāo do RNA podia se dar pela adição assim como pela remoção de uridinas e que ocorria em genes mitocondriais de diferentes membros da ordem Kinetoplastida. Em alguns casos, como o do gene da subunidade III da citocromo oxidase, observou-se que originalmente o gene não continha um ATG de iniciação mas que, após editoraçāo, o códon de iniciação foi criado no transcrito. Além disso, verificou-se que cerca de 50\% da seqüência do transcrito do gene coxlII é criada por editoração (Feagin et al., 1988).

Como possiveis vantagens evolutivas, admite-se que a editoraçāo de RNA poderia ser um ponto de controle da expressăo gênica. Outra vantagem è de que um gene poderia dar origem a várias proteínas diferentes se houvesse uma editoraçāo alternativa, criando uma maior flexibilidade genética. Além disso, uma evolução baseada no RNA poderia representar um risco menor para o organismo, já que um transcrito erroneamente processado poderia ser facilmente substituído, enquanto que uma mutação a nivel de DNA poderia ser fatal ( $c$. Benne, 1990).

A despeiro das evidências descritas acima, o mecanismo de editoração do RNA não era conhecido. Existiam basicamente dois modelos: um assumindo uma seqüência de eventos e atividades enzimáticas envolvidas e outro, postulando a existência de um RNA guia que pudesse dirigir a editoraçāo (cf. Benne, 1990). Blum et al. (1990), realizaram uma 
busca de homologia entre a seqüência conhecida do maxicírculo de $L$ tarentolae, permitindo pareamentos $G-U$, e verificaram que pequenos trechos, geralmente presentes em regiōes intergênicas do maxícirculo, eram homólogas às regiōes editadas dos mRNAs maduros. Essas seqüências, em função do modelo de RNA guia, foram consideradas como genes de gRNA. Os autores também identificaram alguns dos transcritos desses genes de gRNAs e propuseram um modelo de editoração de RNA que envolveria, além dos gRNAs, uma terminal uridiltransferase (TUTase), uma endoribonuclease, uma exonuclease e uma ligase. A busca de um número maior de genes de gRNA levou à descoberta que as regiões variáveis de minicírculos codificam gRNAs de maneira similar à descrita em maxicírculos (Sturm \& Simpson, 1990b). Além disso, estudando mRNAs parcialmente editados, foi verificado que os padrōes de ediçāo encontrados eram compativeis com uma orientaçāo 3'-5' do processo de editoração (Sturm \& Simpson, 1990a). Posteriormente Blum et al. (1991) demonstraram que o mecanismo de editoraçāo envolvia duas etapas de transesterificação. Numa primeira etapa haveria o pareamento entre a extremidade 5' terminal do gRNA e o transcrito. A seguir a hidroxila terminal da cauda do gRNA, que contém um segmento de uridinas, aracaria uma ligação interna do RNA pré-editado, clivando-o. Numa segunda etapa, a hidroxila 3' terminal gerada no RNA pré-editado, atacaria por sua vez uma regiāo de duas uridinas da cauda do gRNA, restaurando a integridade do mRNA com um ganho de uma uridina, e o gRNA que perderia esta uridina.

\subsection{Objetivos do presente trabalho}

Conforme discutido no item 1.1.1, a forma rripomastigota representa o elo de ligaçâo entre as fases de vida do parasita nos hospedeiros vertebrado e invertebrado. Uma das características biológicas maís marcantes deste estágio é a capacidade que ele apresenta de penetrar em vários tipos de células. Até meados da década de 80, os estudos de nosso grupo centravam-se, basicamente, em aspectos da infectividade do parasita in vivo e in vitro, bem como na determinação da composição da membrana celular, de grande importância para o entendimento da interação entre o parasita e a célula hospedeira (Zingales et al, 1982; Zingales e Colli., 1985). A purificação de antígenos de $T$. cruzi é um processo extremamente difícil e de baixo rendimento, principalmente quando se trata de tripomastigotas. Como alternativa, a partir da segunda metade da década 80 foram iniciados estudos de clonagem e expressão de genes de $T$. cnuzi, visando contribuir para o entendimento de aspectos da biologia celular e molecular do parasita, bem como com 
aspectos relacionados com a doença de Chagas. Na época em que nosso trabalho foi iniciado, em 1988, poucos genes de $T$. cruzi haviam sido clonados e caracterizados (Peterson et al, 1986; Ibañez et al., 1987; Beard et al., 1988; Hoft et al., 1989; Lafaille et al., 1989; Takle et al., 1989). O objetivo inicial deste trabalho foi o de implantar a tecnologia da clonagem gênica em nosso laboratório, visando isolar e caracterizar genes que codificam antígenos de $T$. cruzi. Para essa finalidade escolhemos, como sonda para a varredura da biblioteca de expressão, um soro policlonal dirigido contra annigenos da superfície de tripomastigotas. A partir do momento em que dois recombinantes foram isolados, passou a ser nosso objetivo a caracterização destes clones quanto aos seguintes aspectos:

- Identificação dos antígenos clonados;

- Distribuição ceiular no parasita:

- Expressão das proteínas de fusāo;

- Avaliação das proteínas de fusão no diagnóstico sorológico da doença de Chagas:

- Arranjo dos genes no genoma do parasita;

- Transcrição nas diferentes formas evolutivas;

- Seqüência nucleotídica. 


\section{MATERLAL E MÉTODOS}

\subsection{Reagentes}

Apresenta-se abaixo a lista de fabricantes dos principais reagentes e de outros itens de consumo empregados nesse trabalho.

-Ajinomoto Co. Inc.: glicina.

-Amersham: [a-32P]dATP $(3.000 \mathrm{Ci} / \mathrm{mmol}) ;\left[{ }^{35}\right.$ SldATP $\alpha$ S $(>1.000 \mathrm{Ci} / \mathrm{mmol}) ;\left[\gamma^{-32 P] A T P}\right.$ (3.000Ci/mmol); $(\alpha-32$ PldCTP $(3.000 \mathrm{Ci} / \mathrm{mmol}) ;$ matriz de nitrocelulose Hybond $\mathrm{C}$; matriz de nylon Hybond $\mathrm{N}$; proteina A marcada com ${ }^{125} \mathrm{I}$.

-Bayer: Rompun ${ }^{\oplus}$

-Becton-Dickinson: tubos e microplacas de 96 poços Falcon ${ }^{\circ}$ agulhas; seringas.

-BioRad: acrilamida para ácidos nucléicos; colunas de plástico Poly-Prep ${ }^{\circledR}$; resina de troca iônica RG 501-X8.

-Boehringer Manheim: DNase I; DNA polimerase I; Fragmento Klenow da polimerase; Nuclease SI; Proteinase K; Terminal desoxinucleotidil transferase.

-Cario Erba: trietilamina.

-Collaborarive Research: resina oligo dT-celulose.

-Cultilab: soro fetal bovino.

-DIFCO: Bacto-ágar; Bacto-triptona; extrato de levedura.

-Du Pont: placa intensificadora com tungstato de cálcio Cronex Lighming Plus.

-Fluka: isotiocianato de guanidina.

-FMC: Nusieve GTG LMP agarose.

-GIBCO BRL: E. coli DH5 $\alpha$; T4 DNA ligase.

-ICN: dietilpirocarbonato.

-IPEN: $\mathrm{Na}^{131} \mathrm{I}$.

-Labsynth: vaselina.

-May \& Baker - tartarato de sódio/potássio.

-Merck: ácido acético glacial; ácído clorídrico; acetona; cloreto de amônio; n-butanol; cloreto de cálcio; clorofórmio; dietilamina; EDTA; etanol; fenol; formaldeído 37\%; isopropanol; metanol; POPOP; acetato de potássio; cloreto de potássio; reagente de FolinCiocalteau; tolueno.

-Millipore: filtros para esterilização $(0,4 \mu \mathrm{m})$; filtros de nitrocelulose de $85 \mathrm{~mm}$ (HATF).

-Nestlé: leite desnatado Molico 
-New England Biolabs: EcoRI metilase; enzimas de restrição; adaptadores de EcoRI não fosforilados; S-adenosil-L-metionina; T4 DNA ligase; T4 DNA polimerase; T4 polinucleotidio quinase; "Universal Primer (-20) 17 MER": "Reverse Primer (-24) 16 MER".

-Parke-Davis - Ketalar".

-Pharmacia: agarose NA; ATP; ddNTP; dNTP; Ficoll 400; pGEX3X; Sepharose $4 B$ ativada por brometo de cianogênio; Sepharose CL-4B; sulfato de dextrana; T7Sequencing $\mathrm{Kit}^{\mathrm{TM}}$.

-Pierce: azul de bromofenol; lodogen ${ }^{\infty}$.

-Promega: Erase-a-Base ${ }^{\otimes}$; Protoclone ${ }^{2}$ igt l] System; RNasin ${ }^{\circledR}$.

-QEEL: parafina.

-Reagen: ácido bórico; sulfato de amônio; clorero de cálcio; sulfato de cobre; fosfato monobásico de potássio; acetato de sódio; fosfato dibásico de sódio; fosfato monobásico de sódio; frutose; glicose; cloreto de magnésio; sulfato de magnésio; maitose; sacarose; bicarbonato de sódio; citrato de sódio; clorero de sódio; hidróxido de sódio.

-Riedhel de Haën: uréia.

-Sigma: ácido tricloroacético; acrilamida; adjuvante completo de Freund; adjuvante incompleto de Freund; ágar; aprotinina; persulfato de amônio; ampicilina; anticorpo antiIgG de coelho conjugado a peroxidase; anticorpo anti-IgG humana conjugado a peroxidase; anticorpo anti-IgM (cadeia $\mu$ ) humana conjugado a peroxidase; pAPTG-agarose; azul de Coomassie; BSA fração V; CDNB; cioreto de césio; 4-cloro- $\alpha$-naftol; dimetildiclorosilano; DMSO; DNA de esperma de salmão; DTT; espermidina; etanolamina; brometo de etídio; formamida; gelatina; glicerol; glicina; glutationa reduzida; GSH-agarose; HEPES; cloreto de hexaminocobalto; hidroxiquinolina, IPTG; cloreto de litio; cloreto de manganês; marcadores de peso molecular para SDS-PAGF; $\beta$-mercaptoetanol; MES; $N, N^{\prime}$-metileno-bis-acrilamida; Nonidet P-40; MOPS; PEG 8000; PMSF; polivinilpirrolidona; Ponceau S; PPO; putrescina; ONPG; Sarkosyl; SDS; azida sódica; pirofosfato de sódio; TEMED; tiamina; timerosal; TLCK; Triton X-100; Trizma base; Tween 20; X-Gal; xileno cianol FF; sulfato de zinco.

-Synth: carbonato de sódio; terraborato de sódio.

-Stratagene: $\mathrm{pBluescript}{ }^{*} \mathrm{KS}^{-}$.

-Whatman: filtros GF/C; papel 3MM.

-Worthington: lisozima; RNase A.

-USB: T7 DNA polimerase (Sequenase ${ }^{\circledR}$ ).

\subsection{Soluçōes}

TBE 1x- 89 mM Tris-base; 89 mM ácido bórico; 2 mM EDTA, pH 8,3. SSPE $20 \mathrm{x}-3 \mathrm{M} \mathrm{NaCl} ; 0,2 \mathrm{M} \mathrm{NaH}_{2} \mathrm{PO}_{4} ; 20 \mathrm{mM}$ EDTA, pH 7,4. 
Soluçāo de Denhardt $50 x$ concentrada - 1\% (p/v) Ficoll; $1 \%(p / v)$ polivinilpirrolidona; $1 \%(\mathrm{p} / \mathrm{v}) \mathrm{BSA}$.

Tampão MOPS 1x - 20 mM MOPS; 5 mM acetato de sódio pH 7,0; 1 mM EDTA.

SSC $1 \mathrm{x}-0,15 \mathrm{M} \mathrm{NaCl} ; 0,015 \mathrm{M}$ citrato de sódio, $\mathrm{pH} 7,0$.

TAE lx - 40 mM Tris-base; 20 mM ácido acético glacial; 1 mM EDTA, pH 8,3.

$\mathrm{SM}$ - $50 \mathrm{mM}$ Tris- $\mathrm{HCl}$ pH 7,5; $100 \mathrm{mM} \mathrm{NaCl} ; 8 \mathrm{mM} \mathrm{MgCl} ; 0,01 \%$ gelatina.

TBS - $50 \mathrm{mM}$ Tris- $\mathrm{HCl}$ pH 8,0; $150 \mathrm{mM} \mathrm{NaCl}$.

TE - $10 \mathrm{mM}$ Tris $\mathrm{HCl}$ pH 8,0;0,1 mM EDTA.

TES - $10 \mathrm{mM}$ Tris- $\mathrm{HCl}$ pH 8,0; $100 \mathrm{mM} \mathrm{NaCl} ; 0,1 \mathrm{mM}$ EDTA.

TNE - 25 mM Tris- $\mathrm{HCl}$ pH 7,5; $100 \mathrm{mM} \mathrm{NaCl} ; 5$ mM EDTA pH 8,0.

TSM - 50 mM Tris- $\mathrm{HCl} \mathrm{pH} 7,5 ; 100 \mathrm{mM} \mathrm{NaCl} ; 10 \mathrm{mM} \mathrm{MgCl}_{2}$.

2.3. Meios de cultura

2-TY - $16 \mathrm{~g} / \mathrm{L}(\mathrm{p} / \mathrm{v})$ Bacto-triptona; $10 \mathrm{~g} / \mathrm{L}(\mathrm{p} / \mathrm{v})$ extrato de levedura; $10 \mathrm{~g} / \mathrm{L}(\mathrm{p} / \mathrm{v})$ $\mathrm{NaCl}, \mathrm{pH} 7,4$.

$\lambda$ Ágar - Bacto-triptona $10 \mathrm{~g} / \mathrm{L} ; \mathrm{NaCl} 5 \mathrm{~g} / \mathrm{L}$; ágar $15 \mathrm{~g} / \mathrm{L}, \mathrm{pH} 7,4$.

$\lambda$ Top Ȧgar - Bacto-triptona $10 \mathrm{~g} / \mathrm{L} ; \mathrm{NaCl} 5 \mathrm{~g} / \mathrm{L} ;$ ágar $7 \mathrm{~g} / \mathrm{L}, \mathrm{pH} 7,4$.

$\lambda$ Top Agarose - Bacto-tríptona $10 \mathrm{~g} / \mathrm{L} ; \mathrm{NaCl} 5 \mathrm{~g} / \mathrm{L}$; agarose $7 \mathrm{~g} / \mathrm{L}, \mathrm{pH} 7,4$.

LB - Bacto-triptona $10 \mathrm{~g} / \mathrm{L}$; extrato de levedura $5 \mathrm{~g} / \mathrm{L} ; \mathrm{NaCl} 10 \mathrm{~g} / \mathrm{L}, \mathrm{pH} 7,4$.

LB Ágar - LB com $15 \mathrm{~g} / \mathrm{L}$ de ágar.

LBM - LB com $10 \mathrm{mM}$ de $\mathrm{MgSO}_{4}$

Meio $\mathrm{M} 910 \mathrm{x}$ concentrado $-6 \mathrm{~g} / \mathrm{L}(\mathrm{p} / \mathrm{v}) \mathrm{Na}_{2} \mathrm{HPO}_{4} ; 3 \mathrm{~g} / \mathrm{L}(\mathrm{p} / \mathrm{v}) \mathrm{KH}_{2} \mathrm{PO}_{4} ; 0,5 \mathrm{~g} / \mathrm{L}(\mathrm{p} / \mathrm{v})$ $\mathrm{NaCl} ; 1,0 \mathrm{~g} / \mathrm{L}(\mathrm{p} / \mathrm{v}) \mathrm{NH}_{4} \mathrm{Cl}, \mathrm{pH} 7,4$.

Meio mínimo - meio $\mathrm{M9} \mathrm{lx} ; 2 \mathrm{mM} \mathrm{MgSO}_{4} ; 0,2 \%(\mathrm{p} / \mathrm{v})$ glicose; $0,1 \mathrm{mM} \mathrm{CaCl} \mathrm{Cl}_{2} \mathrm{l}$ $\mathrm{mg} / \mathrm{mL}(\mathrm{p} / \mathrm{v}) ; 1 \mathrm{mg} / \mathrm{mL}(\mathrm{p} / \mathrm{v})$ vitamina $\mathrm{Bl} ; 15 \mathrm{~g} / \mathrm{L}(\mathrm{p} / \mathrm{v})$ bacto-ágar.

SOB - Bacto-triptona $20 \mathrm{~g} / \mathrm{L}$; extrato de levedura $5 \mathrm{~g} / \mathrm{L}$ e $\mathrm{NaCl} 0,5 \mathrm{~g} / \mathrm{L}, \mathrm{pH} 7,4$.

\subsection{Bactérias}

Para a estocagem, todas as cepas de bactérias foram cultivadas em meio 2-TY durante 18 horas. $O$ estoque de longo prazo foi feito pela mistura de volumes iguais do cultivo bacteriano e de glicerol estéril e posterior armazenamento em tubos de plástico estéreis a $-70^{\circ} \mathrm{C}$. O mesmo tipo de procedimento foi adotado para o estoque de médio prazo (6 meses) a $-20^{\circ} \mathrm{C}$. Para o uso, procedeu-se a repiques em placas a partir dos tubos estocados a $-20^{\circ} \mathrm{C}$. As placas foram guardadas a $4^{\circ} \mathrm{C}$ e utilizadas no prazo de 2 semanas. Abaixo estão listadas as cepas de E. coli utilizadas e seus respectivos genótipos: 
- BHB2688 (Hohn \& Murray, 1977; Hohn, 1979) - \{N205 recA $\left\{\right.$ \{ imm ${ }^{434}$, cIts, b2, red; Eam, $\operatorname{Sam} \mid / \lambda]$ )

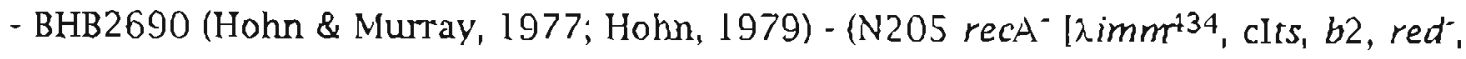
Dam, Sam $\mid / \lambda])$

- DH5 $\alpha^{\otimes}$ (Bethesda Research Laboratories) - F- $\lambda$-recAl endAl hsdRl7 ( $\mathrm{r}_{\mathrm{k}}{ }^{\prime}, \mathrm{m}_{\mathrm{k}}{ }^{+}$,

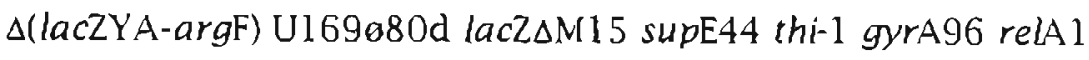

- JM101 - (Yanisch-Perron et al, 1985) - supE, thi, $\triangle\left(\right.$ lac-proAB), $\left[\mathrm{F}^{\prime}\right.$, traD36, proAB, lagl $\mathrm{ZZ \Delta M} 15]$.

- JM109 (Yanisch-Perron et al., 1985) - recAl, endA1, gyrA96, thi, hsdR17, supE44, $\operatorname{re}\left(A 1, \lambda^{-}, \Delta(\right.$ lac-proAB), [F', $\operatorname{traD} 36$, proAB, laqRZ $\triangle \mathrm{M} 15]$

- Q358 (Karn et al., 1980) - hsd $\mathrm{R}_{\mathrm{k}}^{-}$hsd $\mathrm{M}^{+} \mathrm{k}$ supF $080^{\mathrm{r}}$

- Q359 (Karn et al., 1980) - hsdR- ${ }_{\mathrm{k}}$ hsd $\mathrm{M}^{+}{ }_{\mathrm{k}}$ supF $080^{\mathrm{r}} \mathrm{P} 2$

- Y1089 (Young \& Davis, 1983b) - sladU169, proA + , slon, ara D139, strA, hflA150,

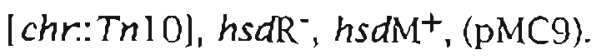

- Y1090 (Young \& Davis, 1983b) - slacU169, proA ${ }^{+}, \Delta l o n$, ara Dl39, strA, supF,

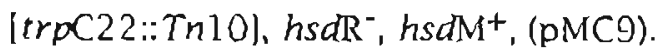

2.5. Vetores

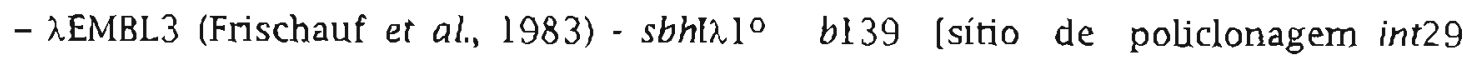
nin44 trpE sítio de policlonageml KH54 chiC sri $4^{\circ} \operatorname{nin} 5 \operatorname{sH} \lambda 5^{\circ}$.

- $\lambda$ gt11 (Young \& Davis, 1983a) - lac5 nins cl857 5100.

- M13mpl 8 (Messing \& Vieira, 1982).

- pBluescript ${ }^{\otimes}$ (Stratagene; Short et al., 1988).

- pGEX3X (Pharmacia; Smith \& Johnson, 1988).

- pMSgtl l (Scherf et al., 1990).

- pUCl 8 (Yanisch-Perron et al, 1985).

\subsection{Parasitas}

Neste estudo utilizou-se basicamente a cepa Y de $T$. cruzi (Silva \& Nussenzweig, 1957). Em alguns casos especificados no texto utilizaram-se as cepas CL (Brener \& Chiari, 1963) e G (Yoshida, 1983). As formas epimastigotas foram cultivadas no meio LIT (infusão de fígado e triptose) de Castellani et al (1967), preparado pela técnica Cecília França Lopes. As formas tripomastigotas de cultura de tecido foram obtidas pela infeçāo de monocamadas de células LLC-MK2, como descrito por Zingales et al. (1982). Os parasitas foram cultivados pelos técnicos do laboratório Marinei Ferreira Gonçalves e Roberto Zangrandi. 


\subsection{Soros}

2.7.1. Soro de coelho anti-tripomastigotas de cultura de tecido (tct) da cepa Y

Este soro foi preparado e cedido pela Dra. Eufrosina S. Umezawa (Instituto de Medicina Tropical, São Paulo). Para sua obtenção, tet foram inativados com o agente intercalante 8-MSOP, conforme previamente descrito (Andrews et al, 1985) e inoculados em coelhos em duas doses com intervalo de 15 dias. Os tripomastigotas assim tratados podem infectar as cèlulas do hospedeiro e se diferenciar em amastigotas, mas não sāo capazes de se multiplicar.

\subsubsection{Obtenção de soros de coelhos anti-proteínas de fusão}

\subsubsection{Emulsificação do antigeno}

Para a imunização de coelhos foram utilizadas doses de $300 \mu \mathrm{g}$ de proteina purificada e liofilizada. A proteína foi dissolvida em $750 \mu \mathrm{l}$ de PBS estéril. Preparou-se uma emulsão de água em óleo empregando um volume igual de adjuvante completo de Freund. Para a emulsificaçāo foram utilizadas duas seringas de vidro com agulhas $25 \times 8$ conectadas entre si por um tubo fino (Tygon ${ }^{\circledR}$ ) ou mediante uma agulha de duplo canhāo. Injetou-se primeiramente a fase aquosa dentro da fase oleosa e a seguir repetiu-se o procedimento em ambas as direções de 25 a 30 vezes. Para comprovar que de fato a emulsāo resultante era de água em óleo e nāo de óleo em água, pingou-se uma gota sobre um frasco com água. Uma gota de uma cmulsâo de água em óleo permanece na superfïcie da água, sem dissolução. Coelhos da raça New Zealand foram imunizados em duplicata pelas duas vias de inoculação descritas a seguir, utilizando-se $300 \mu g$ de proteína emulsificada em cada dose.

\subsubsection{Imunização por inoculações subcutâneas}

Os coelhos foram imunizados por via subcutânea em vários pontos ao longo do dorso e próximos a linfonodos regionais. Na primeira dose empregou-se adjuvante completo de Freund e, dois meses após, aplicou-se a segunda dose, emulsionada em adjuvante incompleto de Freund. Doses subseqüentes foram aplicadas com intervalos de um mês. Os animais foram sangrados regularmente a partir da segunda dose pela veia marginal da orelha para monitoramento da resposta sorológica. O sangue foi incubado por uma hora em estufa a $37^{\circ} \mathrm{C}$ e depois a $4^{\circ} \mathrm{C}$ durante a noite, para melhor retração do 
coágulo. O soro foi então centrifugado a $2.500 \mathrm{rpm}$ em centrifuga de mesa e inativado a $56^{\circ} \mathrm{C}$ por 15 minutos.

\subsubsection{Imunização por múltiplas inoculaçôes intradérmicas}

Seguiu-se, com algumas modificaçōes, técnica descrita por Vaitukaitis (1981). Os coelhos foram sedados com a inoculação por via intramuscular de $25 \mathrm{mg} / \mathrm{kg}$ de Ketalar (cloridrato de quetamina) e $3 \mathrm{mg} / \mathrm{kg}$ de Rompun (cloridrato de xilazina). Em seguida os animais foram tricoromizados na regiāo dorsal entre os membros anteriores e posteriores. A primeira dose do antígeno, emulsificado em adjuvante completo de Freund, foi aplicada em volumes de $50 \mu \mathrm{l}$ por via intradérmica, em um total de 60 pontos de inoculação. Após 60 dias, os animais passaram a ser sangrados mensalmente $e$ inoculados com doses subcutâneas de $300 \mu \mathrm{g}$ emulsificadas em adjuvante incompleto de Freund.

\subsubsection{Soros humanos}

Os soros humanos de individuos normais ou portadores da doença de Chagas, leishmaniose, malária, toxoplasmose e esquistossomose foram obridos de laboratórios de referência (Departamento de Clinica Médica, Faculdade de Medicina, Universidade Federal de Goiás; Instituto de Medicina Tropical e Hospital das Clínicas, Universidade de São Paulo). Estes soros foram previamente testados por exames sorológicos convencionais. Alguns dos pacientes chagásicos foram submetidos a xenodiagnóstico e exames clínicos, incluindo eletrocardiografia, ingestão de contraste de bário e enema de bário. Os soros da regiâo endêmica de Bambuí foram cedidos pelo Dr. E. Chiari e pelo Dr. J.C. Pinto Dias, com informaçōes relativas aos sintomas clínicos dos pacientes e o zimodema dos parasitas isolados destes individuos.

\subsection{Purificação de ácidos nucléicos de T. cruzi}

\subsubsection{Preparação simultânea de DNA e RNA}

\subsubsection{Ultracentrifugação em gradiente de césio}

Com o objetivo de eliminar qualquer fonte de ribonuclease, todas as soluções utilizadas foram tratadas com DEP $0,1 \%(\mathrm{v} / \mathrm{v})$ durante a noite e posteriormente autoclavadas, com exceção da solução de Tris, que somente foi autoclavada. Todo o material de vidraria foi lavado, sêco e esterilizado em formo Pasteur a $180^{\circ} \mathrm{C}$ por 4 horas. 
Uma suspensāo contendo $3 \times 10^{10}$ parasitas foi centrifugada e o sedimento lavado 3 vezes com PBS e estocado a $-70^{\circ} \mathrm{C}$ até o momento do uso.

O método empregado seguiu basicamente o protocolo de Sambrook et al. (1989). 0 sedimento de parasitas foi ressuspenso em $8 \mathrm{~mL}$ de um soluçāo contendo isotiocianato de

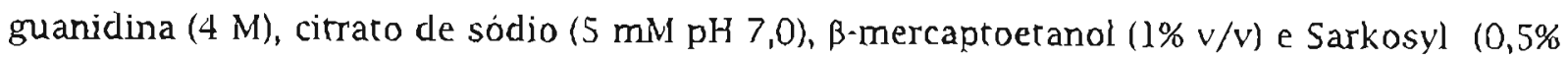
$\mathrm{p} / \mathrm{v})$. Após a total homogeneização, o material foi centrifugado a $5.000 \mathrm{~g}$ por 10 minutos a $10^{\circ} \mathrm{C}$. Uma solução $5,7 \mathrm{M}$ de cloreto de césio em $10 \mathrm{mM}$ EDTA pH 7,5 foi preparada, tratada com DEP e autoclavada. A seguir mediu-se o índice de refração para corrigir a concentração da solução. Volumes de $2 \mathrm{~mL}$ desta solução foram dispensados em tubos (Beckman Ultraclear) do rotor SW.60. Por sobre a solução de césio foram dispensados cuidadosamente cerca de 2,5 mL do homogenato de parasitas. Os tubos foram centrifugados por 18 horas a 40.000 rom na temperatura de $20^{\circ} \mathrm{C}$ em ultracentrifuga Beckman.

\subsubsection{Obtenção do DNA}

Após a centrifugação, retiraram-se cuidadosamente os debris celulares da parte superior dos rubos. Com uma seringa e agulha $30 \times 8$ aspirou-se vagarosamente o DNA, que concentra-se pouco abaixo da interface do homogenato com a solução de césio. O material foi dialisado 3 vezes ( 3 horas cada) contra 1.000 volumes de tampāo ( $10 \mathrm{mM}$ Tris-HCl pH 8,$0 ; 10 \mathrm{mM}$ EDTA pH 8,0;0,5\% p/v SDS). a seguir adicionou-se Proteinase $\mathrm{K}(100 \mu \mathrm{g} / \mathrm{mL})$ e incubou-se por 2 horas a $65^{\circ} \mathrm{C}$. O procedimento acima foi reperido $e_{1}$ após a segunda incubaçāo, o DNA foi extraído com fenol, fenol/clorofórmio e clorofórmio e, finalmente, precipitado com $1 / 10$ volume de acetato de sódio $(3 \mathrm{M} \mathrm{pH} \mathrm{5,3)} \mathrm{e} 2$ volumes de etanol a $20^{\circ} \mathrm{C}$ por 2 horas. Em seguida o DNA foi centrifugado a $12.000 \mathrm{~g}$ por 15 minutos, lavado por duas vezes com etanol 70\%/TE e redissolvido em $10 \mathrm{~mL}$ de TE. Procedeu-se entào a uma digestão com $2 \mu \mathrm{g} / \mathrm{mL}$ de RNase $A$ (livre de DNase) por 30 minutos a $37^{\circ} \mathrm{C}$. O DNA foi então extraido com fenol e clorofórmio e a fase aquosa foi dialisada duas vezes contra 1.000 volumes de TE (10 mM EDTA) e outras duas contra TE $(0,1 \mathrm{mM}$ EDTA). A concentração final do DNA foi determiıada peia absorbância a 260 num (assumindo que 1 D. $._{260}=50 \mu \mathrm{g} D \mathrm{DA} / \mathrm{mL}$ ). $O$ estoque de DNA foi mantido a $4^{\circ} \mathrm{C}$ até o momento do uso.

\subsubsection{Obtençăo do RNA total}

O RNA encontra-se sedimentado no fundo dos tubos. Após a remoção do DNA, os tubos foram cortados com uma navalha quente a uma alnira de cerca de $1 \mathrm{~cm}$ do fundo e a soluçāo remanescente foi cuidadosamente removida. Os tubos foram lavados com etanol $70 \%$ e sêcos à temperatura ambiente. Os sedimentos foram ressuspensos em $4 \mathrm{~mL}$ de TE com $0,1 \%(\mathrm{p} / \mathrm{v})$ de SDS e precipitados com $400 \mu \mathrm{l}$ de acetato de sódio $3 \mathrm{M} \mathrm{pH} 5,2$ e 2,5 
volumes de etanol gelado a $-20^{\circ} \mathrm{C}$ por uma hora. Após uma centrifugação a $12.000 \mathrm{~g}$ por 15 minutos, os sedimentos foram lavados com etanol 70\%, sêcos ao ar e ressuspensos em $2 \mathrm{~mL}$ de água. Mediu-se a absorbância da amostra a 260 nm para estimar a concentraçāo de RNA (assumindo que 1 D. $._{260}=40 \mu \mathrm{g} \mathrm{RNA} / \mathrm{mL}$ ). A solução foi aliquotada, adicionada de 3 volumes de etanol e estocada a $\cdot 70^{\circ} \mathrm{C}$. No momento do uso adicionou-se acetato de sódio para 0,3 M final e centrífugou-se a amostra.

\subsubsection{Purifïcação da fraçāo de RNA mensageiro poli $\mathrm{A}^{+}$}

Para a purificação do mRNA contendo cauda poliadenilada foi empregada uma coluna com a resina oligo dT-celulose. Uma massa de $0,5 \mathrm{~g}$ da resina foi ressuspensa em 0,1 $\mathrm{N} \mathrm{NaOH} \mathrm{e} \mathrm{utilizada} \mathrm{para} \mathrm{empacotar} \mathrm{uma} \mathrm{coluna} \mathrm{de} \mathrm{plástico} \mathrm{descartável} \mathrm{(Poly-Prep} \mathrm{-} \mathrm{BioRad).}$ A resina foi lavada 3 vezes com água e com o tampão de carga $(50 \mathrm{mM}$ cirrato de sódio $\mathrm{pH}$ 7,0; 0,5 M NaCl; 1,0 mM EDTA; 0,1\% Sarkosyl) até o pH ficar abaixo de 8,0. O RNA total foi ressuspenso em $\mathrm{H}_{2} \mathrm{O}$, aquecido a $65^{\circ} \mathrm{C}$ por 5 minutos e rapidamente resfriado em gelo. Adicionou-se um volume de tampāo de carga $2 x$ concentrado e o material foi aplicado na coluna.

Coletou-se o eluato da coluna e adicionou-se mais um volume de tampāo de carga. Após o recolhimento, o eluato foi aquecido a $65^{\circ} \mathrm{C}$ por 5 minutos e reaplicado na coluna. $\mathrm{A}$ coluna foi lavada com 5 a 10 volumes de tampão de carga, coletando-se fraçōes de $1 \mathrm{~mL} e$ medindo-se em seguida a absorbância a $260 \mathrm{~nm}$. Quando as frações apresentaram absorbância próxima de zero, procedeu-se à eluição do mRNA com 2 a 3 volumes de tampão de eluição (10 mM Tris- $\mathrm{HCl}$ pH 7,6; l mM EDTA pH 8,0;0,05\% p/v SDS). A absorbância a $260 \mathrm{~nm}$ foi determinada e as frações de interesse foram reunidas. O RNA foi precipitado pela adição de acetato de sódio para $0,3 \mathrm{M}$ final e 2,5 volumes de etanol, seguida de uma incubação de 30 minutos em gelo. Após uma centrifugação, o sedimento de RNA foi ressuspenso em $\mathrm{H}_{2} \mathrm{O}$ e estocado com 3 volumes de etanol a $-70^{\circ} \mathrm{C}$.

\subsubsection{Preparação do RNA pelo método do fenol quente}

Para a extração rápida de RNA total de $\Upsilon$. cruzi foram utilizados $10^{8}$ epimastigotas ou $2 \times 10^{8}$ tripomastigotas por preparação. Os parasitas foram centrifugados por 1 minuto

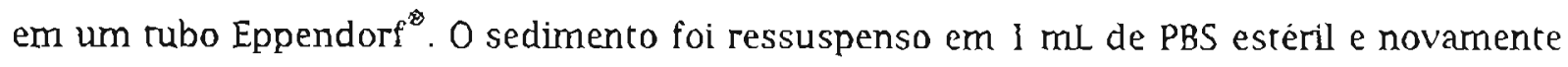
centrifugado por 1 minuto. Em seguida ressuspendeu-se o sedimento em $100 \mu \mathrm{L}$ de PBS e adicionou-se $o$ inibidor de ribonuclease RNasin ${ }^{\circledR}$ para uma concentraçāo final de $0,4 \mathrm{U} / \mu \mathrm{L}$. Paralelamente saturou-se uma solução de fenol com TNE. A seguir adicionou-se ao fenol saturado um igual volume de TNE com $1 \%(\mathrm{p} / \mathrm{v})$ de SDS e manteve-se a mistura em banho a $80^{\circ} \mathrm{C}$, até formar uma solução monofásica. Adicionou-se então $1 \mathrm{~mL}$ da solução de fenol 
quente ao rubo com os parasitas e agitou-se levemente. O tubo foi centrifugado por 5 minutos e a fase aquosa resultante foi extraída com igual volume de clorofórmio. O RNA foi precipitado pela adição de 2,2 volumes de etanol frio à fase aquosa. Manteve-se o tubo a $-20^{\circ} \mathrm{C}$ durante a noite. No dia seguinte o tubo foi centrifugado por 30 minutos a $4^{\circ} \mathrm{C}$. $\mathrm{O}$ sedimento foi ressuspenso em $100 \mu \mathrm{L}$ de água e estocado a $-70^{\circ} \mathrm{C}$ até o momento de uso.

\subsection{Construção de biblioteca genômica de T. cruzi no vetor de expressão $\lambda$ gtll}

\subsubsection{Preparação dos insertos}

Partiu-se de $35 \mu \mathrm{g}$ de DNA de formas epimastigotas da cepa $Y$, purificado como descrito no item 2.8.1. O DNA foi introduzido em uma seringa e submetido a passagens sucessivas através de uma agulha $(13 \times 8)$ por $250,500,750$ e 1.000 vezes, visando atingir um tamanho médio de fragmentos de $3 \mathrm{~kb}$. O DNA fragmentado (28 $\mu \mathrm{g} \mathrm{em} 1,1 \mathrm{~mL}$ ) foi adicionado de $120 \mu \mathrm{L}$ de tampão de $\$ 110 \times$ concentrado (3M NaCl; $0,5 \mathrm{M}$ acetato de porássio $\mathrm{pH} \mathrm{4,6;0,1} \mathrm{M} \mathrm{ZnSO}_{4} ; 50 \%$ glicerol $\left.\nu / v\right)$ e $\perp \mu \mathrm{L}$ de nuclease $\mathrm{Sl}\left(300 \mathrm{U} / \mu \mathrm{L}\right.$ ), e incubado a $37^{\circ} \mathrm{C}$ por 30 minutos. Em seguida o DNA foi extraído com um volume de fenol/clorofórmio e precipitado com 2,5 volumes de etanol a $-20^{\circ} \mathrm{C}$ por 2 horas. Após uma centrifugaçào a $13.000 \mathrm{~g}$ por 15 minutos, o DNA foi lavado com etanol 70\%/TE, sêco sob vácuo e ressuspenso em $200 \mu \mathrm{L}$ de água. À merade desse volume foram adicionados $26 \mu \mathrm{L}$ de tampão de EcoRI metilase $5 \times$ concentrado $(0,5 \mathrm{M}$ Tris- $\mathrm{HCl}$ pH 8,0; $5 \mathrm{mM}$ EDTA; $25 \mathrm{mM}$ DTT), $4 \mu \mathrm{L}$ de 5 -adenosil-metionina $(3,2 \mathrm{mM})$ e $5 \mu \mathrm{L}$ de EcoRI metilase $(20 \mathrm{U} / \mu \mathrm{L})$. A amostra foi incubada por 1 hora a $37^{\circ} \mathrm{C}$ e em seguida extraída e precipitada com descrito acima. A seguir procedeu-se a uma reação de preenchimento com T4 DNA polimerase. Um total de 2 $\mu \mathrm{g}$ de DNA, ressuspensos em $5,2 \mu \mathrm{L}$, foram adicionados de $14 \mu \mathrm{L}$ de tampāo $5 x$ concentrado de T4 DNA polimerase (335 mM Tris- $\mathrm{HCl}$ pH 8,8; $83 \mathrm{mM}$ sulfato de amônio; $33,5 \mathrm{mM} \mathrm{MgCl}$; $50 \mathrm{mM} \beta$-mercaptoetanol; 33,5 mM EDTA), 1,4 $\mu \mathrm{L}$ de dNTP ( $5 \mathrm{mM}$ de cada), 7,0 $\mu \mathrm{L}$ de T4 DNA polimerase e água para um volume final de $70 \mu \mathrm{L}$. Incubou-se a $37^{\circ} \mathrm{C}$ por 40 minutos e, em seguida, o DNA foi novamente extraido e precipitado.

\subsubsection{Marcação radioativa dos adaptadores de EcoRI}

Seguiu-se basicamente o método de Sambrook et al. (1989). Foram utilizados adaptadores de EcoRI nāo fosforilados de 8, 10 e 12 pares de bases. A 2,5 $\mu \mathrm{L}$ de adaptador (cerca de $2,5 \mu \mathrm{g}$ de DNA) foram adicionados $2,0 \mu \mathrm{L}$ de tampão de fosforilação de adaptadores $10 x$ concentrado $\left(0,7 \mathrm{M}\right.$ Tris- $\mathrm{HCl} \mathrm{pH} 7,5 ; 0,1 \mathrm{M} \mathrm{MgCl}_{2} ; 50 \mathrm{mM}$ DTT), $30 \mu \mathrm{Ci}$ de I $\gamma$-32P]ATP, 1,5 $\mu \mathrm{L}$ de polinucleorídio quinase (New England Biolabs - $10 \mathrm{U} / \mu \mathrm{L}$ ) e $\mathrm{H}_{2} \mathrm{O}$ totalizando um volume de $20 \mu \mathrm{L}$. A amostra foi incubada a $37^{\circ} \mathrm{C}$ por 30 minutos e 
posteriormente a $65^{\circ} \mathrm{C}$ por 5 minutos, a fim de inativar a enzima. Cada adaptador foi fosforilado em uma reaçāo individual.

\subsubsection{Controle da eficiência de fosforilaçāo dos adaptadores}

Para se ter certeza de que cada um dos rês adaptadores foi adequadamente fosforilado, procedeu-se a uma reação de ligação. Um volume de $1,5 \mu \mathrm{L}$ da reação de fosforilação foi adicionado de 1,0 $\mu \mathrm{L}$ de tampāo de ligação $10 \mathrm{x}$ concentrado $(660 \mathrm{mM}$ Tris. $\mathrm{HCl} \mathrm{pH} \mathrm{7,6;} 50 \mathrm{mM} \mathrm{MgCl} 2 ; 0 \mathrm{mM}$ DTT; $10 \mathrm{mM} \mathrm{ATP),} 1 \mu \mathrm{L}$ de T4 DNA ligase (1 U Weiss/ $\mu \mathrm{L}$ ) e $\mathrm{H}_{2} \mathrm{O}$ para completar um volume de $10,0 \mu \mathrm{L}$. As amostras foram incubadas a $18^{\circ} \mathrm{C}$ durante a noite. Após uma inativação a $65^{\circ} \mathrm{C}$ por 10 minutos, $5 \mu \mathrm{L}$ de cada reação de ligação foram misturados a $2 \mu \mathrm{L}$ de tampão de EcoRI $5 \times$ concentrado $(500 \mathrm{mM}$ Tris- $\mathrm{HCl} \mathrm{pH} \mathrm{7,5;250} \mathrm{mM}$ $\mathrm{NaCl} ; 25 \mathrm{mM} \mathrm{MgCl} ; 500 \mu \mathrm{g} / \mathrm{mL} \mathrm{BSA}$ ), $1 \mu \mathrm{L}$ de EcoRI (20 U/mL) e $\mathrm{H}_{2} \mathrm{O}$ para um volume final de $10 \mu \mathrm{L}$. Os rubos foram incubados a $37^{\circ} \mathrm{C}$ por 2 horas e a seguir a $65^{\circ} \mathrm{C}$ por 5 minutos. Para a visualização dos resultados, foi preparado um gel de poliacrilamida $8 \%$ em tampào TBE $0,5 x$ contendo $0,06 \%$ de persulfato de amônio 0,03\% de TEMED. Foram utilizados, como amostras, $0,75 \mu \mathrm{L}$ da reação de fosforilação, $5 \mu \mathrm{L}$ da reação de ligação e os $10 \mu \mathrm{L}$ da digestão com EcoRI. Todas as amostras tiveram os seus volumes ajustados para $10 \mu \mathrm{L}$ e foram adicionadas de $2 \mu \mathrm{L}$ de tampão de amostra do tipo II (Sambrook et al, 1989 - 0,25\% $\mathrm{p} / \mathrm{v}$ azul de bromofenol; $0,25 \% \mathrm{p} / \mathrm{v}$ xileno cianol; $15 \% \mathrm{p} / \mathrm{v}$ Ficoll tipo 400). A corrida eletroforética foi realizada em tampão $0,5 \times$ TBE a $100 \mathrm{~V}$ até o azul de bromofenol atingir a metade do gel. O gel foi recoberto com um plástico fino (Magipack ${ }^{\circledR}$ ) e um filme radiográfico foi exposto durante uma hora. Este procedimento controle foi utilizado para cada um dos três adaptadores de forma individual.

\subsubsection{Ligação de insertos com os adaptadores e digestão com EcoRI}

A reação de ligação foi efetuada com $1 \mu \mathrm{g}$ de DNA de inserto, 0,5 $\mu \mathrm{L}$ de cada adaptador fosforilado, $2 \mu \mathrm{L}$ de tampão de ligação $10 x$ concentrado $(660 \mathrm{mM}$ Tris- $\mathrm{HCl} \mathrm{pH}$ 7,6; $50 \mathrm{mM} \mathrm{MgCl}$; $50 \mathrm{mM} \mathrm{DTT;} 10 \mathrm{mM} \mathrm{ATP}$ ), $2 \mu \mathrm{L}$ de $\mathrm{T}_{4}$ DNA ligase (1 U Weiss/ $\mu \mathrm{L}$ ) e $\mathrm{H}_{2} \mathrm{O}$ para um volume final de $20 \mu \mathrm{L}$. O material foi incubado durante a noite a $18^{\circ} \mathrm{C}$ e posteriormente a enzima foi inativada a $65^{\circ} \mathrm{C}$ por 10 minutos. A $18 \mu \mathrm{L}$ da reaçào de ligação foram adicionados $1 \mu \mathrm{L}$ de espermidina $50 \mathrm{mM}, 6,4 \mu \mathrm{L}$ de tampão de restrição de médio sal pH 7,5 5x concentrado (250 mM Tris- $\mathrm{HCl}$ pH 7,5; $250 \mathrm{mM} \mathrm{NaCl} ; 50 \mathrm{mM} \mathrm{MgCl}$; $5 \mathrm{mM} \mathrm{DTT;}$ $500 \mu \mathrm{g} / \mathrm{mL}$ BSA), $5 \mu \mathrm{L}$ de EcoRI (20 U/ $\mu \mathrm{L}$ ), $0,5 \mu \mathrm{L}$ de $\mathrm{NaC}$ ) $2 \mathrm{M}$ e $\mathrm{H}_{2} \mathrm{O}$ para um volume final de $50 \mu \mathrm{L}$. A incubação foi feita a $37^{\circ} \mathrm{C}$ por 4 horas. Como procedimento de controle, procedeuse a uma eletroforese em gel de poliacrilamida, como descrito no item acima, usando como amostras $0,75 \mu \mathrm{L}$ de adaptadores fosforilados, $2 \mu \mathrm{L}$ da reação de ligação e $5 \mu \mathrm{L}$ da 
reaçāo de digestão com EcoRI. A presença de uma banda radioativa de alto peso molecular na amostra de DNA ligado foi indicativa da ocorrência de ligação entre insertos e adaptadores.

\subsubsection{Separaçāo do excesso de adaptadores răo ligados ao DNA dos insertos}

O excesso de adaptadores nāo ligados aos insertos foi removido por gel fuluraçāo em uma coluna de Sepharose CL-4B. A resina foi empacotada e equilibrada em tampão TE/0,6 $\mathrm{M} \mathrm{NaCl}$. A coluna foi calibrada utilizando-se azul dextrana e adapradores radioativos. $O$ material foi aplicado e coletado em um total de 40 fraçōes, cuja radioatividade foi determinada em contador de cintilação liquida, pelo método de Cerenkov. Comparando-se o perfil obtido com aquele padronizado pela passagem de adaptadores nāo ligados, foi possivel coletar as fraçōes correspondentes aos insertos de $T$. cruzi ligados a adaptadores. $O$ volume das frações escolhidas, contendo um total de $800 \mathrm{ng}$ de DNA, foi de $220 \mu \mathrm{L}$.

2.9.6. Reação de ligação entre o DNA de T. cruzi e o DNA de $\lambda$ gt ll

Utilizou-se como vetor o fago igtll (Young \& Davis 1983a), contido no kit Protoclone da Promega. Este kit apresenta uma alta eficiência de recombinação porque o DNA do vetor já vem previamente digerido com EcoRI e defosforilado com fosfatase alcalina de bezerro. Para a reação de ligação utilizou-se uma razāo de 3 moles DNA de inserto por mol de DNA de vetor. Um total de $500 \mathrm{ng}$ de DNA de insertos foi co-precipitado com o DNA do vetor. Após lavagem com etanol 70\%/TE, o DNA foi ressuspenso em $8 \mu \mathrm{L}$ de TE e adicionado de $1 \mu \mathrm{L}$ de tampāo de ligaçăo $10 \times$ concentrado e $1 \mu \mathrm{L}$ de T4 DNA ligase (l U Weiss). Procedeu-se a uma incubaçāo de 18 horas a $16^{\circ} \mathrm{C}$.

\subsubsection{Encapsidação in vitro do DNA}

\subsubsection{Preparação do extrato de empacutamento sonicado (SE)}

Utilizou-se o protocolo descrito em Sambrook et al. (1989). Uma colônia de E. coli da cepa BHB2690 foi cultivada durante a noite em $50 \mathrm{~mL}$ de meio $2-T Y$ a $30^{\circ} \mathrm{C}$. No dia seguinte a D.0.600 foi determinada e inoculou-se um erlenmeyer de 2 litros contendo $500 \mathrm{~mL}$ de meio 2-TY pré-aquecido. Utilizou-se um volume de inóculo suficiente para gerar uma D.O. inicial de 0,1 . O frasco foi incubado sob agitação a $32^{\circ} \mathrm{C}$ até atingir uma D.0.600 $=0,3$. Para a indução, o frasco foi colocado em um banho de água a $65^{\circ} \mathrm{C}$ e, com um termômetro no meio de cultura, foi agitado manualmente atè a remperatura do meio atingir $45^{\circ} \mathrm{C}$. Em seguida o frasco foi transferido para um banho de água a $45^{\circ} \mathrm{C}$ e agitado por 15 minutos 
com o objetivo de inativar o inibidor cI. Posteriormente o frasco foi incubado em estufa, sob agitaçāo vigorosa, a $38-39^{\circ} \mathrm{C}$ por cerca de 2 a 3 horas. Para se monitorar o momento adequado de interromper o cultivo, coletaram-se amostras da cultura e adicionou-se nelas uma gota de clorofórmio. O clareamento do meio, decorrente da lise celular, serviu como indicação de que as cèlulas já apresentavam uma grande concentração das proteínas de empacotamento do fago $\lambda$. Após a incubação, as células foram centrifugadas a $4.000 \mathrm{~g}$ por 10 minutos a $4^{\circ} \mathrm{C}$. O meio foi totalmente drenado e as células ressuspensas em $3,6 \mathrm{~mL}$ de uma soluçāo recém-preparada de rampão de sonicação $(20 \mathrm{mM}$ Tris- $\mathrm{HCl}$ pH $8.0 ; 1 \mathrm{mM}$ EDTA; 5 mM $\beta$-mercaptoetanol). A suspensão foi transferida para um tubo plástico Falcon ${ }^{\ominus}$ e sonicada no gelo com pulsos de 5 segundos cada, com intervalos de 30 segundos na unidade 4 de intensidade do aparelho (Heat Systems, Ultrasonics Inc. - Modelo W185D). Após o clareamento da solução e redução da viscosidade, o lisado foi centrifugado a 12.000 g por 10 minutos a $4^{\circ} \mathrm{C}$. O sobrenadante foi adicionado de um volume de tampão de sonicação frio e $1 / 6$ de volume de tampão de empacotamento (6 mM Tris-HCl pH 8,0; $50 \mathrm{mM}$ espermidina; $50 \mathrm{mM}$ putrescina; $20 \mathrm{mM} \mathrm{MgCl} ; 30 \mathrm{mM}$ ATP; $30 \mathrm{mM} \beta$-mercaptoetanol). A solução foi aliquotada em volumes de $15 \mu \mathrm{L}$ em tubos Eppendorf ${ }^{\text {क }}$ pré-resfriados. Os tubos foram congelados em nitrogênio liquido e estocados a $-70^{\circ} \mathrm{C}$ até o uso.

\subsubsection{Preparação do extrato de empacotamento congelado-degelado (FTL)}

Na preparaçăo do extrato congelado-degelado foi empregada a cepa BHB2688, urilizando-se as mesmas condiçōes de cultivo e induçāo descritas no item anterior, mas em um volume total de cultura de 1,5 litros. O meio foi totalmente drenado $c$ as células ressuspensas em $3 \mathrm{mI}$ de uma solução gelada de $10 \%$ sacarose $/ 50 \mathrm{mM}$ Tris- $\mathrm{HCl} \mathrm{pH} 8,0$. Distribuíram-se 6 frações de $0,5 \mathrm{~mL}$ em rubos Eppendorf ${ }^{\text {}}$ previamente resfriados em gelo. Adicionaram-se a cada fração $25 \mu \mathrm{L}$ de solução recém-preparada de lisozima $(2 \mathrm{mg} / \mathrm{mL} \mathrm{em}$ 0,25 M Tris-HCl pH 8,0) e homogeneizou-se. Os tubos foram congelados em nitrogẽnio líquido e depois deixados descongelar em gelo. A cada rubo foram adicionados $25 \mu \mathrm{L}$ de tampão de empacotamento e homogeneizou-se. Os extratos foram reunidos em um rubo e

centrifugados a $48.000 \mathrm{~g}$ por 1 hora a $4^{\circ} \mathrm{C}$, Após a centrifugaçăo, removeu-se o sobrenadante e aliquotaram-se volumes de $10 \mu \mathrm{L}$ em tubos Eppendorf ${ }^{\circledast}$ pré-resfriados. Os tubos foram congelados em nitrogênio líquido e estocados a $-70^{\circ} \mathrm{C}$ até o uso.

\subsubsection{Reação de encapsidação}

Os tubos contendo os extratos de empacotamento foram removidos do estoque a $-70^{\circ} \mathrm{C}$ e descongelados em gelo. Para a reação de encapsidaçăo foram utilizados $5 \mu \mathrm{L}$ da reaçāo de ligaçāo descrita no item 2.9.6. Adicionaram-se a essa amostra $10 \mu \mathrm{L}$ do extrato 
congelado-degelado (FTL) e $15 \mu \mathrm{L}$ do extrato sonicado (SE). Incubou-se à temperatura ambiente por 2 horas. Em seguida foram adicionados $500 \mu \mathrm{L}$ de SM e uma gota de clorofórmio e a biblioreca foi estocada a $4^{\circ} \mathrm{C}$.

\subsubsection{Determinaçāo do título e taxa de recombinação da biblioteca}

A bactéria Y1090 foi culrivada durante a noite a $37^{\circ} \mathrm{C}$ em meio $2 \cdot T Y$ com $0,2 \%(p / v)$ de maltose. No dia seguinte a cuitura foi centrifugada e ressupensa em SM para uma D. $0_{600}=2,0$. Para a ritulação e determinaçāo da porcentagem de recombinação na biblioteca foram feitas diluiçōes seriadas em SM de uma aliquota da reação de encapsidação. A cada amostra de $100 \mu \mathrm{L}$ foram adicionados $25 \mu \mathrm{L}$ de IPTG 0,1 M, $40 \mu \mathrm{L}$ de X-Gal $\{2 \% \mathrm{p} / \mathrm{v} \mathrm{em}$ DMSO) e $200 \mu \mathrm{L}$ da suspensão de $Y 1090$. Os tubos foram incubados a $37^{\circ} \mathrm{C}$ por 20 minutos para permitir a adsorção dos fagos na superfície das bactérias. Em seguida cada amostra foi misturada com $3 \mathrm{ml}$ de LB Top Ágar (contendo $10 \mathrm{mM}$ de $\mathrm{MgSO}_{4}$ ) pré-aquecído a $48^{\circ} \mathrm{C} \in$ despejada sobre placas de Petri contendo $25 \mathrm{~mL}$ de LB ágar. Após solidificação as placas foram incubadas em posição invertida a $37^{\circ} \mathrm{C}$ por cerca de 18 horas. No dia seguinte a placa contendo um número entre 30 e 300 placas de lise foi selecionada para a contagem. A porcentagem de recombinaçăo foi calculada a partir da razão entre o número de placas de lise brancas (recombinantes) sobre o número total de placas (azuis + brancas).

2.10. Varredura da biblioteca genômica de $T$. cruzi em $\lambda$ gtl 1 com anticorpos

2.10.1. Absorçāo do soro anti-tct

Soros de animais freqüentemente apresentam un alto nível de anticorpos contra antigenos bacterianos. Durante a seleção dos clones recombinantes é desejável a remoção desses anticorpos, afim de se obter respostas mais específicas e reduzir o ruído de fundo. Adaptou-se um método largamente empregado na obtenção de soros destinados à classificação sorotípica de E. coli (Ørskov \& Orskov, 1984). Uma colônia da bactéria Y1090 foi inoculada em $400 \mathrm{~mL}$ de meio 2-TY e cultivada sob agitação vigorosa a $37^{\circ} \mathrm{C}$ durante a noite. No dia seguinte a cultura foi distribuída em dois erlenmeyers. Um dos frascos foi autoclavado a $121^{\circ} \mathrm{C}$ por 1 hora e depois deixado esfriar. À outra alíquota da cultura adicionou-se formaldeído para uma concentração final de $0,5 \%$ e incubou-se com agitação a $37^{\circ} \mathrm{C}$ por 2 horas. As duas suspensōes foram reunidas, lavadas duas vezes com $160 \mathrm{~mL}$ de tampão TBS pH 8,0 e distribuídas em 8 tubos de centrífuga com tampa de rosca (Sorvall). Os tubos foram centrifugados (6.000 g) e os sobrenadantes desprezados. Os tubos conrendo os sedimentos foram estocados a $-20^{\circ} \mathrm{C}$ até o momento do uso. 
Um volume de $600 \mu \mathrm{L}$ de soro anti-rct foi diluido 1:50 em TBS/BSA 1\% totalizando $30 \mathrm{~mL}$. Cada $15 \mathrm{~mL}$ do soro foram colocados em um tubo coniendo um sedimento bacteriano. Os tubos foram vigorosamente agitados até a total ressuspensão e, em seguida, incubados a $4^{\circ} \mathrm{C}$ sob agitação leve por 2 horas. Os tubos foram centrifugados a $6.000 \mathrm{~g}$ por 10 minutos a $4^{\circ} \mathrm{C}$ e os sobrenadantes transferidos para um novo par de tubos. Os sedimentos foram ressuspensos nos soros a repetiu-se o procedimento descrito acima até concluir 4 ciclos de absorção. Finalmente, após a última centrifugação, o soro foi adicionado de timerosal $(0,01 \% \mathrm{p} / \mathrm{v})$, aliquotado em volumes de $2,5 \mathrm{~mL}$, e estocado a $-20^{\circ} \mathrm{C}$ até o momento do uso.

\subsubsection{Seleçāo dos clones recombinantes}

A biblioteca de $\lambda g t l 1$ foi plaqueada com uma densidade de 10.000 UFP por placa de Petri de $85 \mathrm{~mm}$. Os fagos, diluídos em SM, foram incubados com $200 \mu \mathrm{L}$ de uma suspensão de bactérias da cepa Y1090 (D.0.600 $=2,0$ ) por $37^{\circ} \mathrm{C}$ por 20 minutos. Em seguida o material foi misturado a $2,5 \mathrm{~mL}$ de $\lambda$ Top Ágar (contendo $10 \mathrm{mM} \mathrm{MgSO}_{4}$ ), pré-fundido a $+8^{\circ} \mathrm{C}$, e vertido sobre uma placa de Petri contendo $\lambda$ Ágar. As placas foram incubadas a $42^{\circ} \mathrm{C}$ até o surgimento das primeiras placas de lise (cerca de 2,5 a 3 horas) e transferidas para uma estufa a $37^{\circ} \mathrm{C}$. Neste momento foram colocados sobre as placas filtros de nitrocelulose previamente impregnados com $10 \mathrm{mM}$ IPTG, procedendo-se a uma incubaçāo de 3 horas. Os filtros foram entāo lavados em TBS por 10 minutos, bloqueados com TBS/20\% SFB por 30 minuros e incubados durante a noite com o soro a $4^{\circ} \mathrm{C}$. Em seguida os filtros sofreram 5 lavagens de 10 minutos em TBS/0,05\% Tween 20 e um novo bloqueio de 30 minutos com TBS/20\% SFB. A seguir incubaram-se os filtros com TBS/1\% BSA, contendo $5 \times 10^{5} \mathrm{cpm} / \mathrm{mL}$

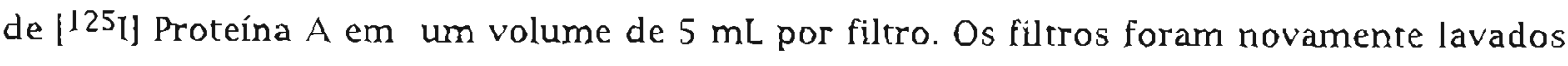
por 5 vezes com TBS/0,05\% Tween 20, sêcos e montados sobre um papel mata-borrão. Procedeu-se à auto-radiografia na presença de uma placa intensificadora de sinal (Du Pont Cronex Lightning Plus) a $\cdot 70^{\circ} \mathrm{C}$ com uma exposição de 24 a 48 horas. Este tipo de placa é constituída de tungstato de cálcio, uma das melhores substâncias fosforescentes para uso em placas e que tem um máximo de eficiência em temperaturas muito baixas (Laskey \& Mills, 1977; Swanstrom \& Shank, 1978). A purificaçào dos clones foi obtida após três ciclos de replaqueamento e incubação com o soro.

2.11. Varredura de biblioteca genômica de T. cruzi em $\lambda$ EMBL3 com sondas radioativas

Uma biblioteca genômica de $T$. cruzi foi construída no vetor $\lambda$ EMBL3 por Monika Vieira de Arruda (Arruda et al., 1990). Esta biblioteca contém insertos da ordem de 15 a 20 kb. Para a vartedura da biblioteca foi utilizada a bactéria hospedeira Q359 (Karn et al.s 
1980). Os fagos ( $10^{4}$ UFP) foram incubados com uma cultura bacteriana (D.0.600 $=2,0$ ) por 15 minutos a $37^{\circ} \mathrm{C}$. A mistura foi adicionada a $3 \mathrm{~mL}$ de $\lambda$ Top Ágar (contendo $10 \mathrm{mM}$ $\mathrm{MgSO}_{4}$ ) pré-fundido a $48^{\circ} \mathrm{C}$ e vertida sobre placas com $\lambda$ Ágar. As placas foram incubadas a $37^{\circ} \mathrm{C}$ durante a noite. No dia seguinte foram colocados filtros de nitrocelulose sobre os meios. O posicionamento dos filtros foi feito por meio de perfurações com agulha e as placas foram deixadas a $4^{\circ} \mathrm{C}$ por 15 minutos. A seguir os filtros foram retirados e réplicas foram feitas através da colocação de novos filtros seguida de mais uma incubação de 15 minutos a $4^{\circ} \mathrm{C}$. Os filtros de nitrocelulose foram então colocados sobre papéis de filtro previamente embebidos em solução $\mathrm{NaOH} 5 \mathrm{~N} / \mathrm{NaCl} 1,5 \mathrm{M}$. Após 2 minutos, os filtros foram parcialmente sêcos em papéis absorventes e mergulhados por 15 segundos em solução Tris- $\mathrm{HCl} 0,5 \mathrm{M} \mathrm{pH} 7,5 / \mathrm{NaCl} 3 \mathrm{M}$. Em seguida as nitroceluloses foram sêcas em papel de fultro e ao ar por 30 minutos. A fixação do DNA na matriz de nitrocelulose foi feita mediante incubaçāo dos filtros a $80^{\circ} \mathrm{C}$ por 2 horas.

Os filtros foram colocados em sacos plásticos e incubados a $67^{\circ} \mathrm{C}$ por 2 horas em tampão de hibridização com $100 \mu \mathrm{g} / \mathrm{mL}$ de DNA de esperma de salmão. Para a hibridização, as sondas foram fervidas por 7 minutos e diluídas para $10^{6} \mathrm{cpm} / \mathrm{mL}$ em zampāo de hibridização com DNA de esperma de salmão. A hibridizaçāo foi realizada a $67^{\circ} \mathrm{C}$ durante a noite. No dia seguinte, os filtros foram submetidos a uma lavagem em solução SSC $3 x /$ SDS $0,1 \%(\mathrm{p} / \mathrm{v})$ por uma hora, uma lavagem com SSC $1 x /$ SDS $0,1 \%(\mathrm{p} / \mathrm{v})$ por mais uma hora e duas lavagens de 30 minutos em SSC $0,1 \times /$ SDS $0,1 \%(\mathrm{p} / \mathrm{v}$ ). Todas as lavagens foram feitas a $67^{\circ} \mathrm{C}$. Os filtros foram sêcos, colocados sobre um papel mata-borrão e recobertos com uma membrana plástica fina (iipo Magipack). A exposição de fiùmes de raios $X$ foi feita por 18 a 36 horas, utilizando um íntensificador, a $-70^{\circ} \mathrm{C}$. Após a revelação das chapas, as regiões das placas de Petri correspondentes aos sinais positivos foram identificadas e excisadas com a ponta largá de uma pipeta Pasteur. A porção de ágar excisada foi agitada em $1 \mathrm{~mL}$ de SM para liberar os fagos. A solução foi entăo dilluida seriadamente em SM. Escolheram-se as diluições que, quando plaqueadas, permitiram obter placas de lise isoladas. A bactéria hospedeira empregada nestes plaqueamentos foi a Q358 (Karn et al., 1980). Todo o procedimento descrito acima foi reperido, visando identificar e isolar de forma pura, por replaqueamentos, as placas de lise que apresentaram sinal positivo de hibridização.

2.12. Preparação de sondas de DNA radioativas

\subsection{1. "Nick-translation"}

Amostras de DNA contendo de 100 a 200 ng totais foram utilizadas para a marcação radioativa por "nick translation". Ao DNA foram adicionados $30 \mu \mathrm{Ci}$ de 
[ $\alpha^{32}$ - P]dATP; $50 \mu \mathrm{M}$ dCTP; $50 \mu \mathrm{M}$ dGTP e $50 \mu \mathrm{M}$ dTTP; $50 \mathrm{mM}$ Tris-HCl (pH 7.5); $10 \mathrm{mM}$ $\mathrm{MgSO}_{4} ; 10 \mathrm{mM} \mathrm{DTT;} 100 \mu \mathrm{g} / \mathrm{mL}$ BSA; $1 \mu \mathrm{L}$ de DNase l (diluição l:10.000 da preparaçāo comercial) e $5 \mathrm{U}$ de DNA Polimerase I, em um volume total de $50 \mu \mathrm{L}$. A reação foi incubada a $16^{\circ} \mathrm{C}$ por 90 minutos e interrompida pela adição de $2 \mu$ de $0.5 \mathrm{M}$ EDTA pH 8,0. Em seguida o volume foi completado para $100 \mu \mathrm{L}$ com solução TES.

\subsection{2. "Primer extension"}

Para esse protocolo foram utilizadas preparações de ssDNA de clones recombinantes no vetor M13, como descrito no item 2.25.2.1. A erapa de hibridizaçāo foi feita com $6 \mu \mathrm{L}$ da preparação de fita molde, $4 \mu \mathrm{L}$ de solução de iniciador $(0,2$ picomoles $/ \mu \mathrm{L})$ e $2 \mu \mathrm{L}$ de tampào 10x concentrado ( $54 \mathrm{mM}$ Tris $\mathrm{HCl} \mathrm{pH} 7,6 ; 0,27 \mathrm{M} \mathrm{NaCl} ; 54 \mathrm{mM} \mathrm{MgCl}_{2} ; 6 \mathrm{mM} \mathrm{DTT}$ ) a $65^{\circ} \mathrm{C}$ por 30 minutos. Após esfriamento à temperanra ambiente, adicionaram-se $5 \mu \mathrm{L}$ de uma solução de desoxínucleońdios $(0,5 \mathrm{mM}$ de cada, com exceção de dATP), $50 \mu \mathrm{Ci}$ de l $\alpha$ ${ }^{32} \mathrm{PIdATP}, 0,5 \mu \mathrm{L}$ de fragmento Klenow da E.coli DNA polimerase I ( $5 \mathrm{U} / \mu \mathrm{L}$ ) e $\mathrm{H}_{2} \mathrm{O}$ qsp $20 \mu \mathrm{L}$. Incubou-se рог 10 minutos à temperatura ambiente e a seguir foram adicionados $2 \mu \mathrm{L}$ de dATP $(0,5 \mathrm{~mm})$. Incubou-se a amostra por mais 5 minutos e a reaçăo foi interrompida com a adição de $1 \mu \mathrm{L}$ de EDTA $0.5 \mathrm{M} \mathrm{pH} \mathrm{8,0.0} \mathrm{volume} \mathrm{foi} \mathrm{então} \mathrm{completado} \mathrm{para} 100 \mu \mathrm{L}$ com solução TES.

\subsubsection{Remoção dos nucleotídios não incorporados}

Os nucleotidios não incorporados foram removidos através de gel filtraçāo (Sambrook et al, 1989). Uma seringa de insulina de $1 \mathrm{~mL}$ foi empacotada com resina Sephadex G-50 pré-equilibrada em TES e colocada dentro de um tubo Corex ${ }^{\otimes}$ de $15 \mathrm{~mL}$ contendo no seu interior um tubo Eppendorf ${ }^{*}$. O volume de $100 \mu \mathrm{L}$ da reação de marcação foi aplicado na seringa. Centrifugou-se a $1.000 \mathrm{rpm}$ por 3 minutos em um centrífuga de mesa. Aplicaram-se mais $50 \mu \mathrm{L}$ de TES e novamente centrifugou-se. Finalmente, recolheu-se o tubo Eppendorf ${ }^{\circledast}$ contendo a sonda marcada.

\subsubsection{Determinação da incorporação dos nucleotidios radioativos}

Transferiu-se $1 \mu \mathrm{L}$ da solução de sonda radioativa para um tubo Eppendorf $\mathrm{e}^{-}$ adicionaram-se $89 \mu \mathrm{L}$ de pirofosfato de sódio $0,2 \mathrm{M}$ e $10 \mu \mathrm{L}$ de DNA de esperma de salmāo $(3 \mathrm{mg} / \mathrm{mL}$ ). Uma alíquota de $10 \mu \mathrm{L}$ foi dispensada em um filtro de fibra de vidro (Whatman GF/C), para determinar a radioatividade total. Ao volume restante foram adicionados 0,5 mL de pirofosfato de sodio $0,2 \mathrm{M}$ e $2,5 \mathrm{~mL}$ de uma soluçăo de pirofosfato de sódio $0,1 \mathrm{M}$ contendo $20 \%(\mathrm{p} / \mathrm{v})$ de TCA. A precipitaçāo dos ácidos nucléicos foi feita em gelo por 10 minutos e, a seguir, o conteúdo foi filtrado sob vácuo, em filtro GF/C 
previamente equilibrado em soluçāo de pirofosfato de sódio 0,1 M/TCA 5\%. O filtro foi lavado com $15 \mathrm{~mL}$ de TCA $5 \%$ e $5 \mathrm{~mL}$ de etanol, e sêco em estufa a $67^{\circ} \mathrm{C}$. Os filtros foram colocados em frascos contendo $5 \mathrm{~mL}$ de solução PPO-POPOP $10,4 \%$ difeniloxazol e $0,01 \% 1,4$ bis(5-fenil-2-oxazolil]-benzeno) e a radioatividade foi determinada em contador de cintilaçāo líquida (LKB).

2.13. Preparaçāo de DNA de fago $\lambda$

\subsubsection{Minipreparaçăo de DNA de fago $\lambda$}

Utilizou-se um método derivado dos protocolos descritos por Sambrook et al. (1989) e Lockett (1990). Uma suspensāo contendo a bactéria hospedeira infectada com fagos foi misturada com $3 \mathrm{~mL}$ de $\lambda$ Top Agarose e vertida sobre placas contendo meio $\lambda$ Agarose. Utilizou-se uma densidade de UFP capaz de formar uma lise confluente. Após uma incubação a $37^{\circ} \mathrm{C}$ durante a noite, despejaram-se $3 \mathrm{~mL}$ de diluente $\lambda(10 \mathrm{mM}$ Tris- $\mathrm{HCl} \mathrm{pH}$ 7,5; $10 \mathrm{mM} \mathrm{MgSO}_{4}$ ) sobre as placas que em seguida foram agitadas à temperarura ambiente por 2 horas. O lisado foi recolhido e centrifugado a $10.000 \mathrm{~g}$ por 10 minuros a $4^{\circ} \mathrm{C}$. Ao sobrenadante adicionaram-se $5 \mu \mathrm{L}$ de RNase $A(1 \mathrm{mg} / \mathrm{mL})$ e $5 \mu \mathrm{L}$ de DNAse $(1 \mathrm{mg} / \mathrm{mL})$ e incubou-se a $37^{\circ} \mathrm{C}$ por 30 minutos. Em seguida adicionou-se um volume de solução $20 \%$ $\mathrm{PEG} / 2,5 \mathrm{M} \mathrm{NaCl}$ e incubou-se por uma hora em gelo. O sedimento contendo os fagos foi ressuspenso em $500 \mu \mathrm{L}$ de solução $10 \mathrm{mM}$ Tris- $\mathrm{HCl}$ pH 8,0; $20 \mathrm{mM}$ EDTA; 0,5\% SDS; 50 $\mu \mathrm{g} / \mathrm{mL}$ Proteinase $\mathrm{K}$ e incubado a $65^{\circ} \mathrm{C}$ por uma hora. O material foi submerido a uma extraçāo com fenol e outra com clorofómio. O DNA foi precípitado pela adição de $10 \mu \mathrm{L}$ de $5 \mathrm{M} \mathrm{NaCl}$ e urn volume de isopropanol e posterior incubaçāo a $-70^{\circ} \mathrm{C}$ por 15 minutos. Após uma centrifugação de 15 minutos a $13.000 \mathrm{~g}$, o sedimento de DNA foi lavado com etanol 70\%, sêco sob vácuo e ressuspenso em $50 \mu \mathrm{L}$ de TE.

\subsubsection{Preparação de DNA de fago $\lambda$ em larga escala}

\subsubsection{Cultivo de fagos em larga escala}

Inoculou-se uma colônia da bactéria hospedeira em $50 \mathrm{~mL}$ de caldo 2-TY, acrescido de $0,2 \%(\mathrm{p} / \mathrm{v})$ de maltose e $\mathrm{MgSO}_{4} 10 \mathrm{mM}$ final. O meio foi incubado durante a noite, a $37^{\circ} \mathrm{C}$. sob agitação. Dois erlenmeyers de 2 litros, com $500 \mathrm{ml}$ de caldo 2-TY (10 mM MgSO $)_{4}$ cada um, foram inoculados com $5 \mathrm{~mL}$ da cultura, e incubados sob agitação a $37^{\circ} \mathrm{C}$, até uma D. $0.600=0,5$ (cerca de $2 \times 10^{11}$ células totais por frasco). Cada frasco foi adicionado de $2 \times$ $10^{10}$ fagos, mantido em repouso por 10 minutos a $37^{\circ} \mathrm{C}$ e, em seguida, incubado sob vigorosa agitação a $37^{\circ} \mathrm{C}$ até a lise das células bacterianas. Adicionaram-se a cada frasco 10 $\mathrm{mL}$ de clorofórmio e procedeu-se a uma incubação de 30 minutos a $37^{\circ} \mathrm{C}$, sob agitação. Tal 
medida visou lisar as células ainda remanescentes no meio. Em seguida forara dissolvidos $30 \mathrm{~g}$ de $\mathrm{NaCl}$ em cada frasco. As culturas foram mantidas em gelo por uma hora e a seguir centrifugadas a $10.000 \mathrm{~g}$ por 15 minutos, a $4^{\circ} \mathrm{C}$. Ao sobrenadante adicionou-se lentamente PEG 8000, até a concentração atingir $10 \%(\mathrm{p} / \mathrm{V})$. A suspensāo de fagos foi incubada a $4^{\circ} \mathrm{C}$ durante a noite, com agitação lenta, e centrifugada no dia seguinte a $10.000 \mathrm{~g}$ por 15 minutos, a $4^{\circ} \mathrm{C}$. O sobrenadante foi descartado e as paredes dos tubos foram sêcas com algodão. O sedimento contendo os fagos foi ressuspenso em $20 \mathrm{~mL}$ de TSM (10 mM Tris$\mathrm{HCl} \mathrm{pH} 7,4 ; 100 \mathrm{mM} \mathrm{NaCl}$ e $10 \mathrm{mM} \mathrm{MgCl}_{2}$ ). A suspensāo foi submetida a uma ultracentrifugaçāo em gradiente descontínuo, com $9 \mathrm{~mL}$ de $3 \mathrm{M} \mathrm{CsCl}$ e $9 \mathrm{~mL}$ de $5 \mathrm{M} \mathrm{CsCl}$ em TSM, a $22.000 \mathrm{rpm}$ por 90 minutos, em rotor Beckman SW 27, a $18^{\circ} \mathrm{C}$. A banda opalescente de fagos, formada na interface $3 \mathrm{M} / 5 \mathrm{M}$ de $\mathrm{CsCl}$, foi recolhida e colocada em um tubo de $13,2 \mathrm{~mL}$ do rotor Beckman SW 4l. O volume dos tubos foi completado com uma soluçāo $4 \mathrm{M}$ de $\mathrm{CsCl}$ em TSM, e as amostras foram centrifugadas a $38.000 \mathrm{rpm}$ por 18 horas, a $18^{\circ} \mathrm{C}$. A banda de fagos, com cerca de $1 \mathrm{~mL}$, foi colerada e guardada a $4^{\circ} \mathrm{C}$ até posterior purificação do DNA.

\subsubsection{Purificação de DNA de fago $\lambda$}

A suspensão de fagos foi dialisada contra 1.000 volumes de TSM por uma hora. Trocou-se o tampão e dialisou-se por mais uma hora. A seguir adicionaram-se a cada amostra de fagos Proteinase $\mathrm{K}(50 \mu \mathrm{g} / \mathrm{mL}), 20 \mathrm{mM}$ EDTA e $0,5 \%(\mathrm{p} / \mathrm{v})$ de SDS. Incubou-se a $67^{\circ} \mathrm{C}$ por uma hora. A seguir as amostras foram extraidas duas vezes com fenol, e cinco vezes com clorofómio. A suspensão aquosa de fagos foi entāo dialisada contra 1000 volumes de TE, com 3 trocas, a $4^{\circ} \mathrm{C}$. A concentração do DNA foi determinada pela mediçāo da absorbância a $260 \mathrm{~nm}$. O grau de pureza foi estimado pelo quociente entre as leituras obtidas a 260 e $280 \mathrm{~nm}$.

\subsection{Purificação de DNA de plasmídio}

\subsubsection{Minipreparações de DNA de plasmídio}

Seguiu-se basicamente o método da lise alcalina (Sambrook et al, 1989). Uma colônia da bactéria contendo o plasmidio foi inoculada em $10 \mathrm{~mL}$ de caldo 2-TY (com 50 $\mu \mathrm{g} / \mathrm{mL}$ de ampicilina) e incubada a $37^{\circ} \mathrm{C}$ durante a noite, sob agitação. A seguir $1,5 \mathrm{~mL}$ da cultura foram transferidos para um tubo Eppendorf ${ }^{\circ}$ e centrifugados por 1 minuto em microcentrifuga (13.000 g). O sobrenadante foi aspirado e o sedimento bacteriano foi ressuspenso em $100 \mu \mathrm{L}$ de uma solução fria de $50 \mathrm{mM}$ glicose $/ 10 \mathrm{mM}$ EDTA/25 mM Tris.Cl pH 8,0. Incubou-se à temperatura ambiente por 5 minutos e, a seguir, adicionaram-se 200 
$\mu \mathrm{L}$ de uma solução $\mathrm{NaOH} 0,2 \mathrm{~N} / \mathrm{SDS} 1 \%(\mathrm{p} / \mathrm{v})$. O rubo foi invertido rapidamente por 3 vezes para uma homogeneizaçāo e posteriormente foram adicionados $150 \mu \mathrm{L}$ de uma soluçāo fria de acetato de potássio $3 \mathrm{M} \mathrm{pH} \mathrm{4,8.} \mathrm{Agitou-se} \mathrm{o} \mathrm{rubo} \mathrm{por} 10$ segundos e centrifugou-se a $4^{\circ} \mathrm{C}$ por 5 minutos. O sobrenadante foi transferido para um novo tubo e extraido com volume igual de fenol/clorofórmio e depois clorofórmio. Após centrifugação, a fase aquosa foi transferida para outro rubo e o DNA precipitado com 2 volumes de etanol, à temperatura ambiente, por 2 minutos. $O$ tubo foi centrifugado por 5 minutos à temperatura ambiente e o sedimento de DNA plasmidial, lavado duas vezes com etanol $80 \% / T E$. A seguir o sedimento foi seco sob vácuo por 30 minutos e ressuspenso em $50 \mu \mathrm{L}$ de TE contendo $20 \mu \mathrm{g} / \mathrm{mL}$ de RNase livre de DNase. Esse tipo de preparação foi urilizada para obter DNA destinado a digestões por enzimas de restrição, visando identificar a presença de um inserto em clones recombinantes.

\subsubsection{Minipreparações rápidas de DNA ("speed preps").}

Para a seleção de clones com seqüências sobrepostas gerados pela digestão com Exonuclease III (ver item 2.25.1) utilizou-se um protocolo originalmente descrito por He et al. (1990) para digestōes por enzimas de restrição e posteriormente aplicado ao seqüenciamento de DNA (Goode \& Feinstein, 1992). Esta técnica permite a realizaçāo de um número muito grande de preparaçôes em um tempo muito curto, gerando um DNA de pureza suficiente para a digestão com enzimas de restrição ou mesmo uma reação de seqüenciamento.

Colônias bacterianas contendo o plasmídio recombinante foram inoculadas em $2 \mathrm{~mL}$ de caldo $2-T Y$ (contendo $50 \mu \mathrm{g} / \mathrm{mL}$ de ampicilina) e cultivadas a $37^{\circ} \mathrm{C}$ durante a noite. No dia seguinte $1,5 \mathrm{~mL}$ do meio foram transferidos para um tubo Eppendorf e centrifugados por 30 segundos. O sedimento bacteriano foi ressuspenso em $100 \mathrm{~mL}$ de solução TELT (50 mM Tris-HCl pH 8,0; 62,5 mM EDTA; 2,5 M LiCl; $4 \%(v / v)$ Triton X-100) e extraído com 100 $\mu \mathrm{L}$ de fenol saturado com Tris- $\mathrm{HCl} \mathrm{pH} \mathrm{8,0/ciorofómio} \mathrm{l}: \mathrm{l}$, agitando-se vigorosamente por 10 segundos cada tubo. Após centrifugação de 2 minutos em microcentrífuga ( $13.000 \mathrm{~g}$ ), a fase superior foi cuidadosamente removida e transferida para um tubo contendo $200 \mu \mathrm{L}$ de etanol gelado. O rubo foi agitado rapidamente e centrifugado por 5 minutos. O sedimento contendo o DNA foi lavado com etanol $70 \%$, sêco sob vácuo por 15 minutos $\in$ ressuspenso em $20 \mathrm{~mL}$ de $\mathrm{TE}$ contendo $100 \mu \mathrm{g} / \mathrm{mL}$ de RNase $A$.

\subsubsection{Midipreparação de DNA de plasmídio}

Para a obtenção de DNA plasmidial, em quantidade e pureza adequadas para a determinação de mapas de restrição e seqüência nucleotidica, procedeu-se ao método da 
lise alcalina baseado no protocolo de Davis et al. (1986). Bactérias contendo o plasmídio recombinante foram inoculadas em $20 \mathrm{~mL}$ de caldo $2-\mathrm{TY}$ (contendo $50 \mu \mathrm{g} / \mathrm{mL}$ de ampicilina) e incubadas a $37^{\circ} \mathrm{C}$ durante a noite. No dia seguinte as células foram centrifugadas a 5.000 g por 10 minutos. O sedimento bacteriano foi ressuspenso em $600 \mu \mathrm{L}$ de tampāo com glicose $(50 \mathrm{mM}$ glicose; $10 \mathrm{mM}$ EDTA; $25 \mathrm{mM}$ Tris- $\mathrm{HCl} \mathrm{pH} \mathrm{8,0)} \mathrm{e} \mathrm{incubado} \mathrm{por} 5$ minutos à temperatura ambiente. Adicionaram-se então à amostra 1,2 ml de solução 0,2 N NaOH/1\% SDS e incubaram-se os tubos por 5 minutos em gelo. 0 material foí transferido para rubos Corex com capacidade de $15 \mathrm{~mL}$ e adicionado de $900 \mu$ de solução gelada de acetato de potássio ( $3 \mathrm{M}, \mathrm{pH} 4,8$ ). A seguir centrifugaram-se os tubos a $12.000 \mathrm{~g}$ por 10 minutos a $4^{\circ} \mathrm{C}$. O sobrenadante foi transferido a outro tubo e o DNA precipitado com um volume de isopropanol a $-20^{\circ} \mathrm{C}$ por 15 minutos. Após uma centrifugação a $12.000 \mathrm{~g}$ por 15 minutos a $4^{\circ} \mathrm{C}$, o sedimento de DNA foi ressuspenso em $1,5 \mathrm{~mL}$ de $T E$, adicionado de RNase $A$ (livre de DNase) na concentraçāo final de $50 \mu \mathrm{g} / \mathrm{mL}$ e incubado por 20 minutos a $37^{\circ} \mathrm{C}$. O DNA foi extraído uma vez com um volume de fenol e uma vez com um volume de clorofórmio. A seguir o DNA foi precipitado pela adição de acetato de sódio $(\mathrm{pH} 5,2)$ na concentração de $0,3 \mathrm{M}$ e 2,5 volumes de etanol, com uma incubação a $-20^{\circ} \mathrm{C}$ por 30 minutos. Após uma centrifugação a $12.000 \mathrm{~g}$ por 15 minutos a $4^{\circ} \mathrm{C}$, o sedimento foi lavado com $1 \mathrm{~mL}$ de etanol $70 \%$ e sêco sob vácuo. Finalmente, o DNA foi ressupenso em $200 \mu \mathrm{l}$ de TE, o que corresponde a uma concentração de DNA de cerca de $250 \mu \mathrm{g} / \mathrm{mL}$.

\subsubsection{Preparação de DNA de plasmídio em gradiente de cloreto de césio}

Foi utilizado um método comunicado pessoalmente pelo Dr. Hernando del Portillo (Depro. de Parasitologia, ICB - USP). Células bacterianas contendo o plasmídio foram cultivadas em $200 \mathrm{~mL}$ de caldo $2-\mathrm{TY}$ (contendo $50 \mu \mathrm{g} / \mathrm{mL}$ de ampicilina) a $37^{\circ} \mathrm{C}$ durante a noite. No dia seguinte as bactérias foram centrifugadas a $5.000 \mathrm{~g}$ por 10 minutos a $4^{\circ} \mathrm{C}$ e 0 sobrenadante descartado. Os sedimentos ressuspensos em $1,5 \mathrm{~mL}$ de soluçāo STE (25\% p/v sacarose; $50 \mathrm{mM}$ Tris-HCl pH 8,0; $100 \mathrm{mM}$ EDTA pH 8,0) foram transferidos para tubos Beckman \#326819 (Polyallomer) e adicionados de $100 \mu \mathrm{l}$ de lisozima $(20 \mathrm{mg} / \mathrm{mL}$ ). Após uma incubaçāo de 5 minutos em gelo, foram adicionados $2,3 \mathrm{~mL}$ de Soluçāo de Triton X-100 e incubou-se por mais 20 minuros em gelo. A seguir os tubos foram centrifugados a 45.000 rpm por 20 minutos a $15^{\circ} \mathrm{C}$ em rotor Beckman SW 50.1. O sobrenadante foi misturado a 3,8 $\mathrm{g}$ de cloreto de césio e $200 \mu \mathrm{l}$ de brometo de etidio $(10 \mathrm{mg} / \mathrm{mL})$ e incubado em gelo, no escuro, por uma hora. As amostras foram entăo centrifugadas a 10.000 rpm por 15 minutos a $4^{\circ} \mathrm{C}$ em rotor Sorvall SS-34. O sobrenadante foi transferido para um tubo Beckman \#344075 (Quick-Seal/Ultra-Clear). Centrifugaram-se os tubos em rotor Beckman VTi-65 a $45.000 \mathrm{rpm}$ por 16 horas a $15^{\circ} \mathrm{C}$. Os tubos foram iluminados com luz UV. de onda longa e a banda correspondente ao plasmídio foi removida com agulha e seringa em um volume de I 
mL. O DNA foi extraido 5 vezes com uma solução de 2-propanol saturado em solução aquosa saturada com $\mathrm{NaCl}$. Esta etapa tem a finalidade de remover o brometo de etídio, bem como trocar os íons de cèsio por sódio. O volume das amostras foi aumentado com TE para $4 \mathrm{~mL}$ e o DNA foi precipitado pela adiçāo de $8 \mathrm{~mL}$ de etanol e posterior incubação a $20^{\circ} \mathrm{C}$ por pelo menos 2 horas. Após uma centrifugação a $12.000 \mathrm{~g}$ a $4^{\circ} \mathrm{C}$ por 15 minutos, o sedimento de DNA foi lavado com etanol 70\%, sêco sob́ vácuo e ressuspenso em $500 \mu \mathrm{\mu l}$ de TE. A concentraçāo de DNA foi determinada através da medida da absorbància a $260 \mathrm{~nm}$ (assumindo I D. $0.260=50 \mu \mathrm{g}$ de DNA $/ \mathrm{mL}$ ).

\subsection{Subclonagem de fragmentos de DNA}

\subsubsection{Digestão do DNA com enzimas de resniçāo}

As amostras de DNA foram digeridas em um volume final de 20 a $50 \mu$ com a enzima de restrição desejada (2 a $5 \mathrm{U} / \mu \mathrm{g}$ de DNA), incubando-se a $37^{\circ} \mathrm{C}$ por 3 a 5 horas. Utilizou-se o tampão recomendado pelo fabricante (New England Biolabs) para cada enzima. Nas digestões múltiplas urilizou-se o sistema de 4 tampões do fabricante. Alrernarivamente foi empregado um sistema de três tampões: sem sal, médio sal (50 mM final de $\mathrm{NaCl}$ ) ou de alto sal (100 mM $\mathrm{NaCl}$ ), descrito por Fuchs \& Blakesley (1983) e cuja composiçāo está descrita abaixo. Alèm disso, todas as digestões foram efetuadas na presença de $1 \mathrm{mM}$ final de espermidina. Foi demonstrado (Bouché, 1981) que a espermidina melhora a eficiência da digestão, possivelmente porque, sendo uma poliamina, tem a capacidade de se ligar ao DNA e deslocar moléculas que poderiam inibir a digestào.

Tampāo de restrição com baixo sal pH 8,0 5x concentrado - $250 \mathrm{mM}$ Tris- $\mathrm{HCl}$ pH 8,0; $50 \mathrm{mM} \mathrm{MgCl}$; $5 \mathrm{mM}$ DTT; $500 \mu \mathrm{g} / \mathrm{mL}$ BSA.

Tampão de restriçāo com médio sal pH 8,0 5x concentrado - 250 mM Tris- $\mathrm{HCl}$ pH 8,$0 ; 250 \mathrm{mM} \mathrm{NaCl} ; 50 \mathrm{mM} \mathrm{MgCl} ; 5 \mathrm{mM} \mathrm{DTT} ; 500 \mu \mathrm{g} / \mathrm{mL}$ BSA.

Tampão de restrição com alto sal pH $8,05 x$ concentrado - $250 \mathrm{mM}$ Tris- $\mathrm{HCl}$ pH 8,0; $500 \mathrm{mM} \mathrm{NaCl} ; 50 \mathrm{mM} \mathrm{MgCl} ; 5 \mathrm{mM}$ DTT; $500 \mu \mathrm{g} / \mathrm{mL} \mathrm{BSA}$.

Após a incubaçāo, a amostra foi aquecida a $65^{\circ} \mathrm{C}$ por 5 minutos para inativar a enzima, o DNA foi extraído com fenol e clorofórmio, e precipitado com acetato de sódio e etanol a $-20^{\circ} \mathrm{C}$ por 2 horas. 


\subsubsection{Eletroforese em minigel de agarose}

Com a finalidade de monitorar a eficiência das digestões com enzimas de restrição, utilizou-se um gel de agarose com uma concentração de $0,7 \%$ a 1,2\%, em funçāo da faixa de resoluçāo desejada. Para a preparação do gel, a agarose foi misturada com uma soluçāo de TBE $1 x$ e fundida em forno de microondas. Após o resfriamento do gel até $60^{\circ} \mathrm{C}$, adicionouse brometo de etídio para uma concentração final de $0.5 \mu \mathrm{g} / \mathrm{mL}$. Amostras de DNA, previamente acrescidas de tampão de amostra de DNA $6 x$ concentrado ( $30 \% \mathrm{v} / \mathrm{v}$ glicerol; $0,25 \% \mathrm{p} / \mathrm{v}$ azul de bromofenol; $0,6 \% \mathrm{p} / \mathrm{v}$ SDS; $60 \mathrm{mM}$ EDTA, $\mathrm{pH} 8,0$ ), foram aquecidas a $65^{\circ} \mathrm{C}$ por 5 minutos e imediatamente colocadas em gelo e aplicadas no gel. A corrida eletroforética foi feita em tampāo TBE $1 x$ contendo $0,5 \mu \mathrm{g} / \mathrm{mL}$ de brometo de etídio, sob tensāo constante de $8 \mathrm{~V} / \mathrm{cm}$ em cubas pequenas ou até uma voltagem total cle $150 \mathrm{~V}$, no sistema de minigel da Hoefer. Como marcador de peso molecular foi urilizado o DNA de $\lambda$ cI857 digerido com HindIII ou com EcoRI/HindIII .

2.15.3. Purificaçāo de fragmentos de DNA a partir de géis de agarose de baixo ponto de fusão (agarose LMP)

O DNA foi digerido com a(s) enzima(s) de restriçāo apropriada(s) e submetido a uma eletroforese $\mathrm{cm}$ um gel de agarose de baixo ponto de fusão em tampão TAE ix, na concentração de $1,0 \%$. A corrida eletroforética foi feita à temperatura ambiente com uma circulação contínua de tampão, a fim de manter o pH homogêneo em toda a cuba ao longo da corrida eletroforética. Foi utilizado brometo de etídio na concentração de $0,5 \mu \mathrm{g} / \mathrm{mL}$ no gel e no tampão de corrida. Após a corrida, o gel foi iłuminado com uma lâmpada de UV de ondas longas e as bandas desejadas foram excisadas com um estilete. Os fragmentos de agarose foram colocados no interior de tubos Eppendorf previamente pesados. $O$ volume do fragmento de agarose excisado foi estimado pela diferença de peso dos tubos. As amostras foram colocadas em um banho de água a $67^{\circ} \mathrm{C}$ por 5 minutos para fundir a agarose LMP e então adicionaram-se 5 volumes de solução $50 \mathrm{mM}$ Tris pH 7,5/2 mM EDTA pH 8,0. Os tubos foram novamente mantidos em banho a $67^{\circ} \mathrm{C}$ por mais 10 minutos e, em seguida, as amostras foram extraidas com fenol, fenol/clorofórmio e clorofórmio. O DNA foi precipitado mediante a adiçāo de 0,5 volume de acetato de amônio $7,5 \mathrm{M} \mathrm{pH} \mathrm{6,0} \mathrm{e}$ incubação durante a noite a $-20^{\circ} \mathrm{C}$. Após uma centrifugação de 15 minutos a $13.000 \mathrm{rpm}$, o sedimento de DNA foi lavado com TE/etanol $80 \%$, sêca sob vácuo por 20 minutos e ressupenso em $50 \mu$ de TE. Um volume de $5 \mu$ da amostra foi aplicado em um minigel de agarose e submetido à eletroforese. A visualização da banda purificada permitiu estimar a concentraçāo de DNA, bem como a pureza do fragmento recuperado. 


\subsubsection{Reação de ligação}

A reaçāo de ligação foi realizada com cerca de 20 ng totais de DNA e relaçōes molares vetor/inserto de $1: 1,1: 3$ e 1:5. As condiçōes finais da reação foram $60 \mathrm{mM}$ Tris- $\mathrm{HCl}$ $\mathrm{pH}$ 7,5, $5 \mathrm{mM} \mathrm{MgCl}_{2}, 1 \mathrm{mM}$ ATP, $10 \mathrm{mM}$ DTT e 1 U Weiss de T4 DNA ligase, em um volume total de $20 \mu \mathrm{L}$. A incubação foi feita a $18^{\circ} \mathrm{C}$ durante a noite.

\subsubsection{Preparação de células bacterianas competentes e transformaçāo}

A preparação de células competentes foi feita de acordo com o protocolo de Hanahan (1985). Uma colônia em placa da bactéria hospedeira foi utilizada para inocular um Erlenmeyer contendo $20 \mathrm{~mL}$ de meio 2-TY. O frasco foi cultivado durante a noite a $37^{\circ} \mathrm{C}$. Um inóculo desta cultura foi adicionado a cem volumes de caldo SOB contendo 10 $\mathrm{mM} \mathrm{MgSO}_{4}$. Procedeu-se a uma incubaçāo a $37^{\circ} \mathrm{C}$, sob agitação, até que a D. 0.600 atingisse um valor entre 0,4 a 0,6. O frasco foi então mantido em gelo por 10 minutos e, em seguida, o conteúdo foi centrifugado a $1.000 \mathrm{~g}$ a $4^{\circ} \mathrm{C}$ por 15 minutos. O sobrenadante foi muito bem drenado e as células bacterianas foram ressuspensas em $1 / 3$ do volume inicial em TFB (100 $\mathrm{mM} \mathrm{KCl} ; 45 \mathrm{mM} \mathrm{MnCl} 2.4 \mathrm{H}_{2} \mathrm{O} ; 10 \mathrm{mM} \mathrm{CaCl} 2.2 \mathrm{H}_{2} \mathrm{O} ; 3 \mathrm{mM}$ cloreto de hexaminocobalto; 10 MM K-MES, pH 6,3). Seguiu-se uma incubação de 10 minutos em gelo e nova centrifugação. As células foram então ressupensas em 1/12,5 do volume original em TFB, e adicionou-se 3,5\% v/v de DnD (l M DTT; 90\% DMSO; 10 mM acetato de potássio, pH 7,5). Procedeu-se a uma incubação de 10 minutos em gelo e adicionou-se mais DnD, para completar 7,0\% final, seguindo-se mais uma incubação de 10 a 20 minutos em gelo. A suspensão de células foi transferida para tubos de ensaio previamente resfriados, em aliquotas de $200 \mu \mathrm{l}$. Para a transformação adicionou-se o DNA da respectiva amostra e incubou-se por 20 a 40 minutos em gelo. As células transformadas foram então submetidas a um choque térmico a $42^{\circ} \mathrm{C}$ por 90 segundos e nova incubação no gelo por 2 minutos. No caso de plasmídios, o conteúdo dos tubos foi espalhado com uma alça de Drigalski sobre placas de Petri contendo LB Ágar. No caso específico dos vetores pBluescript e pUC, foram aplicadas com uma alça de Drigalski $65 \mu$ de X-Gal (2\% p/v) e $25 \mu$ de IPTG $(0,1 \mathrm{M})$ nas placas de LB Ágar, antes do plaqueamento das bactérias transformadas. Para o plaqueamento de clones de M13, o IPTG e X-Gal foram adicionados a $3 \mathrm{~mL}$ de Top Ágar ainda fundido. Em seguida a suspensão de células foi misturada ao meio e vertida sobre placas de LB ágar. As colônias ou placas contendo o vetor recombinante apresentam coloração branca, enquanto que as não recombinantes desenvolvem uma cor azul. As placas foram incubadas a $37^{\circ} \mathrm{C}$ durante a noite. 


\subsubsection{Identificação dos clones recombinantes}

No caso da subcionagem no vetor pBluescript ${ }^{\$}$, as colônias brancas obtidas a partir da transformaçāo foram cultivadas em caldo 2-TY, seguindo-se minipreparaçōes de DNA plasmidial, como descrito no irem 2.14.1. As amostras de DNA foram digeridas com as enzimas de restrição apropriadas (ver item 2.15.1) e submetidas a uma eletroforese em um minigel de agarose como descrito (item 2.15.2). Os clones foram identificados em funçāo da presença e tamanho dos respectivos insertos. Nas subclonagens eferuadas no vetor M13, as placas brancas foram utilizadas como inóculos para a preparação de moldes de fita sirnples destinados ao seqüenciamento de DNA. A confirmação da subclonagem foi feita por seqüenciamento do DNA e comparação com o vetor nāo recombinante.

\subsection{Expressāo dos antígenos clonados}

\subsubsection{Expressão das proteínas de fusão em bactérias lisogênicas de $\lambda g t l l$}

\subsubsection{Obtençāo de bactérias lisogênicas}

Foram utilizadas células da cepa Y1089, que apresenta alta freqüência de lisogenizaçāo. Uma colônia foi inoculada em um frasco com $20 \mathrm{~mL}$ de meio LB (contendo $0,2 \%$ maltose e $50 \mu \mathrm{g} / \mathrm{mL}$ ampicilina) e incubou-se a $37^{\circ} \mathrm{C}$ durante a noite. Esta cultura fresca foi urilizada como inóculo, na diluiçāo 1:100, de outro Erlenmeyer com $20 \mathrm{~mL}$ de LBM. A incubaçāo foi feita a $37^{\circ} \mathrm{C}$, sob agitação, até a cultura atingir uma $D .0_{600}=1,25$ ( \pm $10^{9}$ bactérias/mL). Foram testadas três multiplicidades de infecção: $100 x, 500 x$ e 1000x. Para cada infecção misturaram-se em um tubo $200 \mu \mathrm{L}$ de um lisado de $\lambda$ gt 11 recombinante de título conhecido, e um volume apropriado da cultura de Y1089, conforme a multiplicidade desejada. Os tubos foram mantidos a $32^{\circ} \mathrm{C}$ por 30 minutos. A cultura de cada tubo foi semeada em estrias até o esgotamento em uma placa de meio LB Ágar (com ampicilina $50 \mu \mathrm{g} / \mathrm{mL}$ ). As placas foram incubadas a $32^{\circ} \mathrm{C}$ durante a noite. Cerca de 15 colônias isoladas de cada placa foram coletadas com alça de platina e ressuspensas individualmente em $200 \mu \mathrm{L}$ de caldo LB. De cada suspensão foram feitas inoculações de 2 $\mu \mathrm{L}$, em duplicata, sobre placas de LB Agar. Uma placa foi incubada a $30^{\circ} \mathrm{C}$ e a outra a $42^{\circ} \mathrm{C}$, por cerca de 18 horas. As bactérias lisogênicas crescem a $30^{\circ} \mathrm{C}$ mas não a $42^{\circ} \mathrm{C}$, devido ao ciclo lítico do fago $\lambda$. As colônias presentes somente na placa cultivada a $30^{\circ} \mathrm{C}$ foram então escolhidas. 
2.16.1.2. Expressão das proteínas de fusão por indução das bactérias lisogênicas

Uma colônia da bactéria lisogênica foi utilizada como inóculo de um Erlenmeyer com $10 \mathrm{~mL}$ de caldo LBM. Incubou-se a $32^{\circ} \mathrm{C}$ até a a cultura atingir D.0.600 $=0,5$. Procedeuse à induçāo em banho de água a $65^{\circ} \mathrm{C}$ e, através de um termômetro inserido dentro do frasco, deixou-se o meio atingir $42^{\circ} \mathrm{C}$. O frasco foi então colocado rapidaraente em um banho a $42^{\circ} \mathrm{C}$ e mantido sob agitação vigorosa durante 20 minutos. Alíquotas de $1 \mathrm{~mL}$ foram transferidas para 5 tubos de vidro previamente colocados em banho de água a $37^{\circ} \mathrm{C}$. Em 4 dos tubos foi adicionado IPTG para $10 \mathrm{mM}$ final (110 $\mu \mathrm{L}$ de uma soluçāo $100 \mathrm{mM}$ de IPTG). Os tubos com IPTG foram incubados sob agitação a $37^{\circ} \mathrm{C}$ por períodos de $30,60,90$ e 120 minutos, enquanto o tubo sem IPTG permaneceu incubando por 90 minutos. Ao final da incubação cada amostra foi transferida para um tubo Eppendorf e centrifugada a 12.000 g por 5 minutos. O sobrenadante foi aspirado e o sedimento ressuspenso em $200 \mu \mathrm{L}$ de tampão de amostra de proteína, fervido por 3 minutos e analisado em SDS-PAGE.

2.16.2. Subclonagem de Bl 2 e Bl3 em pMSgtl l e expressão (fusão com B-galactosidase)

\subsubsection{Purificação dos insertos e ligação com o vetor}

O DNA dos fagos recombinantes Bl2 e Bl3 foi obtido por minipreparações (ver item 2.13.1), digerido com EcoRI (ver item 2.15.1.) e submetido a uma eletroforese em gel de agarose LMP. Os respectivos insertos foram purificados a partir de uma eletroforese em gel de LMP agarose (ver item 2.15.3). O DNA dos insertos foi ligado ao DNA do vetor pMSgt ll previamente linearizado com EcoRI conforme técnica descrita anteriormente (item 2.15.4). O DNA foi entāo utilizado para transformar células competentes da cepa DH5 $\alpha$ (ver item 2.15.5).

\subsubsection{Imunoensaio de colônias bacterianas}

O vetor pMSgtll apresenta um sítio de EcoRI no mesmo passo de leirura do vetor $\lambda g t l 1$, de forma que insertos subclonados, desde que na orientaçāo adequada, expressam corretamente a mesma proteina. Para se determinar quais colônias bacterianas transformadas continham o inserto ligado na orientação correta, utilizou-se um ensaio de seleção imunológica. Empregou-se o método descrito por Helfman et al. (1983) com algumas modificações.

Placas de LB Ágar (contendo ampicilina $50 \mu \mathrm{g} / \mathrm{mL}$ ) inoculadas com as bactérias transformadas foram incubadas durante a noite a $37^{\circ} \mathrm{C}$. No dia seguinte as colônias de cada placa foram cobertas com um filtro de nitrocelulose (Millipore HATF). $O$ 
posicionamento do filtro foi marcado com uma agulha. Os filtros foram retirados lentamente, tomando-se o cuidado de não arrastar as colônias. Os filtros foram então colocados sobre novas placas com meio $\mathrm{LB}$ /ampicilina, com as colonias voltadas para cima. As placas originais e réplicas foram incubadas a $37^{\circ} \mathrm{C}$ por 2 horas. A seguir os filtros, com as colônias para cima, foram colocados sobre folhas de papel Whatman 3MM previamente embebidas em solução de SDS $1 \%(\mathrm{p} / \mathrm{v})$. Após uma incubação de 15 minutos, os fúltros foram colocados dentro de uma cuba saturada com vapores de clorofórmio e deixados a $37^{\circ} \mathrm{C}$ por 15 minutos. Em seguida procedeu-se a uma lavagem dos filtros por uma hora em tampāo TBS com BSA 3\% $(\mathrm{p} / \mathrm{v})$, lisozima $10 \mu \mathrm{g} / \mathrm{mL}$ e DNase I $5 \mu \mathrm{g} / \mathrm{mL}$. Os filtros foram então incubados em dupla, dentro de sacos plásticos, com o soro anti-tct na diluição 1:200, durante a noite a $4^{\circ} \mathrm{C}$. No dia seguinte procedeu-se a 5 lavagens de 10 minutos com TBS/Tween $200,05 \%(\mathrm{v} / \mathrm{v})$ e uma lavagem em TBS/BSA $1 \%(\mathrm{p} / \mathrm{v})$ por 30 minutos. A seguir os filtros foram incubados durante uma hora com [125I] Proteina A diluida em TBS/BSA $1 \%\left(10^{6} \mathrm{cpm} / \mathrm{mL}\right)$. Após 5 lavagens de 10 minutos em TBS/Tween 20 os filtros foram secos ao ar e submetidos à auto-radiografia em filmes de raios $X$, com uma placa intensificadora. A exposição foi feita por 18 a 36 horas a $-70^{\circ} \mathrm{C}$. As colônias das placas originais, reconhecidas pelo soro, foram inoculadas em novas placas e utilizadas para os ensaios de expressão das proteínas de fusão.

\subsubsection{Produção das proteínas de fusāo}

Bactérias da cepa DH5 $\alpha$ contendo o vetor pMSgt l I recombinante foram inoculadas em placas de ágar LB/ampicilina de forma a se obter colônias isoladas. Inoculou-se uma colônia em $10 \mathrm{~mL}$ de caldo 2-TY/ampicilina e procedeu-se a uma incubaçāo a $37^{\circ} \mathrm{C}$, sob agitação, durante a noite. No dia seguinte urilizou-se $1 \mathrm{~mL}$ da cultura como inóculo de 100 $\mathrm{mL}$ de caldo 2-TY. O meio foi incubado sob agitação a $37^{\circ} \mathrm{C}$ por 7 horas. Após esse periodo a cultura foi centrifugada a $6.000 \mathrm{~g}$ por 10 minutos a $4^{\circ} \mathrm{C}$. O sedimento bacteriano foi congelado em gelo seco/acetona e estocado a $-20^{\circ} \mathrm{C}$ até o momento do uso.

\subsubsection{Obtenção do lisado bacteriano}

O sedimento bacteriano foi ressuspenso em $10 \mathrm{~mL}$ de tampão de lise TSM (Tris- $\mathrm{HCl}$ $50 \mathrm{mM} \mathrm{pH} \mathrm{7,5;} \mathrm{NaCl} 100 \mathrm{mM} ; \mathrm{MgCl}_{2} 10 \mathrm{mM}$ ) adicionado de PMSF e TLCK para $1 \mathrm{mM}$ final e de lisozima $0,2 \mathrm{mg} / \mathrm{mL}$. Incubou-se à temperatura ambiente por 20 minutos para se obter a lise celular. O volume do lisado foi aumentado com a adiçāo de mais $20 \mathrm{~mL}$ de TSM, e submetido a 3 ciclos de 10 segundos de sonicação (Modelo W185D - Heat Systems, Ultrasonics [nc.) na unidade 4 de intensidade. Este procedimento visou fragmentar parcialmente o DNA e reduzir a viscosidade da solução. 
Altemarivamente, quando se buscava obter uma pequena amostra de lisado, destinada a uma eletroforese, foi empregado um outro método. Um volume de $1 \mathrm{~mL}$ da cultura foi centrifugado em tubo Eppendorf ${ }^{\oplus}$ por 1 minuto. O sobrenadante foi desprezado e o sedimento ressuspenso em $200 \mu \mathrm{l}$ de tampāo de amostra de proteina (ver item 2.19). Como esse tampão já contém SDS, a líse bacteriana è quase instantânea. A solução foi então fervida por 3 minutos e analisada em géis de poliacrilamida com SDS.

\subsubsection{Determinação da solubilidade das proteínas de fusão}

As proteinas de fusão freqüentemente formam corpúsculos de inclusão insolúveis nas células bacterianas, que podem ser facilmente purificados. Para verificar se as proteínas de fusão estavam presentes nesses corpúsculos seguiu-se o protocolo desenvolvido por Marco Krieger (FIOCRUZ/RJ), modificado a partir de Marston (1987). Partiu-se de 3 mL do lisado bacteriano, correspondente a $10 \mathrm{~mL}$ da cultura original, e aumentou-se o volume com TSM para $20 \mathrm{~mL}$. O lisado foi centrifugado a $8.000 \mathrm{~g}$ por 15 minutos a $4^{\circ} \mathrm{C}$. $\mathrm{O}$ sedimento foi então submetido a uma seqüência de ciclos de lavagem/centrifugação utilizando, respectivamente, TSM, TSM/Triton X-100 0,1\%(v/v) e TSM/Triton X-100 0,5\% $(v / v)$. Todos os precipitados foram ressuspensos em $20 \mathrm{~mL}$ (2 vezes o volume original da cultura). Após a última centrifugação o sedimento foi ressuspenso em $1 \mathrm{~mL}$ (1/10 do volume original) de TSM/uréia $6 \mathrm{M}$ e incubado a $37^{\circ} \mathrm{C}$ por uma hora. Em seguida centrifugou-se a $22.000 \mathrm{~g}$ por 30 minutos. A solução foi então dialisada durante a noite contra 1.000 volumes de TSM, com uma troca. Esta solução e os demais sobrenadantes obtidos durante a execução do protocolo foram liofilizados e utilizados para análise por eletroforese em géis de poliacrilamida com SDS.

\subsubsection{Cromatografia de afinidade em colunas de pAPTG-agarose}

As proteínas de fusão presentes no lisado bacteriano foram purificadas por cromatografia de afinidade, segundo o método de Steers et al. (1971). Uma coluna de vidro com $7 \mathrm{~mm}$ de diâmetro por $10 \mathrm{~cm}$ de altura foi empacotada com $1 \mathrm{~mL}$ da resina pAPTGagarose. A resina foi equilibrada com TSM e $8 \mathrm{~mL}$ de lisado bacteriano (ver item 2.16.2.4) foram aplicados na coluna. Esse volume foi reciclado por 5 vezes, com um fluxo de uma gota a cada 15 segundos. A seguir a coluna foi lavada com $30 \mathrm{~mL}$ de TSM e as proteínas de fusâo eluídas em rampão tetraborato de sódio 0,1 M com pH 10,0. Foram recolhidas frações de $1 \mathrm{~mL}$ em um total de $20 \mathrm{~mL}$. A coluna foi reequilibrada em TSM, podendo ser reutilizada cerca de 6 a 8 vezes. No sistema de expressāo DH5a/pMSgtll as proteínas de fusão mantém a atividade enzimática. Dessa forma, as fraçōes coletadas foram analisadas quanto à atividade enzimática da $\beta$-galactosidase quimèrica. As fraçōes ativas foram reunidas e 
dialisadas durante a noite contra 1000 volumes de água destilada, com uma troca. Em seguida determinou-se a concentração protéica pelo método de Hartree (1972) e a solução foi aliquotada e liofilizada.

\subsubsection{Detecção da atividade de $\beta$-galacrosidase}

Para a identificação das fraçōes ativas da separação cromatográfica foi utilizado um microensaio qualitativo baseado no método descrito por Steers et al. (1971). Volumes de $100 \mu \mathrm{L}$ do substrato ONPG $(0,75 \mathrm{~g} / \mathrm{L}$ em tampão TSM) foram dispensados em rubos Eppendorf ${ }^{\circledast}$ e incubados a $37^{\circ} \mathrm{C}$ por 5 minutos. Em seguida foram adicionadas aliquotas de 2,5 $\mu \mathrm{L}$ de cada fraçāo. Os rubos foram agitados e deixados à temperatura ambiente por 5 minutos. O desenvolvimento de uma coloração amarela indicava qualitativamente a atividade da enzima $\beta$-galactosidase.

\subsubsection{Subclonagem e expressāo do fragmento S3S4 em pGEX3X (fusāo com GST)}

\subsubsection{Construçāo do clone pGEX3X-S3S4}

O DNA do clone BGE 7 (ver figura 8) teve o fragmento S3S4 subclonado no vetor pBluescript $^{2}$ conforme técnica descrita anteriormente (itens 2.15.1 a 2.15.6). O DNA de pBluescript ${ }^{\circledR}$-S3S4 foi digerido com a enzima HincII, que cliva todo sítio de Sall, mas gera fragmentos com extremidades alinhadas. O DNA foi submetido a uma eletroforese em LMP agarose e a banda de $1,85 \mathrm{~kb}$, correspondente ao fragmento S3S4, foi excisada e purificada conforme técnica descrita no item 2.15.3. Adaptadores de EcoRI de 8, 10 e 12 pb foram fosforilados com $\mid \gamma^{32}$ PIATP (ver itens 2.9 .2 e 2.9.3) e ligados ao DNA de S3S4. A seguir a amostra foi digerida com EcoRl e a eficiencia das reaçōes de ligação e digestão foi monutorada em gel de poliacrilamida seguido de auto-radiografia (ver item 2.9.4). Posteriormente o DNA foi submetido a uma nova eletroforese em gel de LMP agarose com a finalidade de eliminar o excesso de adaptadores não ligados. A banda de $1,85 \mathrm{~kb}$ foi

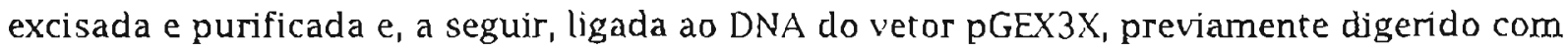
EcoRI (como descrito no item 2.15.4). O DNA ligado foi utilizado para transformar células bacterianas da cepa DH5a (conforme item 2.15.5). Para a seleção dos clones positivos, que apresentam o inserto ligado na oricntação c passo de leitura corretos, foi urilizado o imunoensaio de colônias.

Para o imunoensaio de colônias bacterianas utilizou-se basicamente o protocolo relatado no item 2.16.2.2. A única diferença é que os filtros de nitrocelulose, utilizados para a obtençāo de placas réplicas, foram previamente impregnados com uma solução $10 \mathrm{mM}$ de IPTG. Além disso, espalharam-se com uma alça de Drigalski $40 \mu \mathrm{L}$ de $100 \mathrm{mM}$ IPTG sobre as 
placas de LB/Ampicilina, antes da aplicação dos filtros réplicas. Esse procedimento visou induzir a produçào das proteinas de fusão. O imunoensaio foi realizado com o soro anti-tct na diluição l:200, previamente absorvido contra antígenos bacterianos (ver item 2.10.1).

\subsubsection{Cinética de expressão da proteína de fusāo GST-S3S4}

Para se testar as melhores condiçōes de expressão da proteina recombinante GSTS3S4 no vetor pGEX, cada colônia bacteriana foi inoculada em $2 \mathrm{~mL}$ de caldo 2-TY (contendo $100 \mu \mathrm{g} / \mathrm{mL}$ de ampicilina). Após uma incubaçāo de uma hora a $37^{\circ} \mathrm{C}$ adicionou-se IPTG para uma concentração final de $0,1 \mathrm{mM}$. Foram testados periodos de incubação pós-indução de $1,2,3$ e 4 horas. Volumes de $1 \mathrm{~mL}$ da cultura foram centrifugados em tubos Eppendorf ${ }^{\circledR}$ por um minuto. O sobrenadante foi desprezado e o sedimento ressuspenso em $200 \mu \mathrm{L}$ de tampão de amostra de proteína. Após uma homogeneização, os tubos foram fervidos por 3 minutos e alíquotas de $20 \mu \mathrm{L}$ foram submetidas a uma eletroforese em gel de poliacrilamida com SDS (segundo Laemmli, 1970 - ver item 2.19). Após a corrida gel foi corado com azul de Coomassie ou então transferido para nitrocelulose para um ensaio de Western blot.

\subsubsection{Produção de proteína de fusão}

\subsection{Cultivo das células e indução}

Uma colônia bacteriana foi inoculada em $10 \mathrm{~mL}$ de caldo 2-TY (com ampicilina) e o meio incubado a $37^{\circ} \mathrm{C}$ durante a noite. No dia seguinte procedeu-se a uma subculrura em $100 \mathrm{~mL}$ de caldo $2-T Y$, com posterior incubação por 90 minutos a $37^{\circ} \mathrm{C}$. Após esse período, adicionou-se IPTG para uma concentração final de $0.1 \mathrm{mM}$ e prolongou-se a incubação por mais três horas e meia. O meio foi então centrifugado a $5.000 \mathrm{~g}$ por 10 minutos e o sobrenadante desprezado. O sedimento bacteriamo foi congelado rapidamente em gelo seco com etanol, e armazenado a $-20^{\circ} \mathrm{C}$ até o momento de ser utilizado para a purificação da proteína de fusāo.

\subsection{Obtenção do lisado das células bacterianas}

Um sedimento bacteriano resultante de $100 \mathrm{~mL}$ de cultura foi ressuspenso em PBS (150 $\mathrm{mM} \mathrm{NaCl} ; 16 \mathrm{mM} \mathrm{Na}_{2} \mathrm{HPO}_{4} ; 4 \mathrm{mM} \mathrm{NaH}_{2} \mathrm{PO} ; \mathrm{pH} 7,3$ ) contendo inibidores de proteases (1 mM final de PMSF e TLCK). A suspensão foi submetida a 3 ciclos de 10 segundos de sonicação (Heat Systems, Ultrasonics Inc. - Modelo W185D) na unidade 4 de intensidade. A seguir o lisado foi centrifugado a $13.000 \mathrm{~g}$ por 10 minutos a $4^{\circ} \mathrm{C}$. Adicionou-se Triton $\mathrm{X}-100$ 
para uma concentraçāo final de 1\%. Este detergente tem a finalidade de diminuir as interações inespecíficas entre componentes do lisado bacteriano e a resina de GSH-agarose.

\subsubsection{Purificação da proteina GST-S3S4}

\subsection{Cromatografia de afinidade}

2.16.3.4.1.1. Cromatografia de afinidade em resina de GSH-agarose

Um volume de $10 \mathrm{~mL}$ de lisado bacteriano foi incubado em lote com $1 \mathrm{~mL}$ de resina GSH-agarose, previamente equilibrada em PBS pH 7,3. Procedeu-se a uma incubaçāo de 30 minutos à temperatura ambiente, sob agitação leve. O material foi centrifugado a $1.000 \mathrm{rpm}$ por 3 minutos em centrifuga de mesa (Beckman - modelo TJ-6 com rotor TH4) e lavado por 4 vezes com $15 \mathrm{~mL}$ de PBS. A eluíção foi feita com $1 \mathrm{~mL}$ de Tris-HCl $50 \mathrm{mM} \mathrm{pH} \mathrm{8,0/CSH} 5$ $\mathrm{mM}$, incubando-se por 2 minutos. Dois ciclos subseqüentes de eluição foram realizados e o eluato cotal foi dialisado durante a noite contra 1.000 volumes de PBS, a $4^{\circ} \mathrm{C}$. A concentraçăo protéica foi determinada segundo o método de Hartree (1972). A resina, após a eluição, foi lavada com $15 \mathrm{~mL}$ de PBS e estocada a $4^{\circ} \mathrm{C}$ com timerosal $0,01 \%(\mathrm{p} / \mathrm{v})$ até um mês.

\subsection{Detecção da atividade enzimática de CST}

Foi padronizado um sistema semi-quantitativo de deteç̧ão da atividade enzimática de GST, modificado a partir do protocolo de Simons \& Vander Jagt (1977). Para a reaçāo foram dispensados em um tubo $167 \mu \mathrm{L}$ de tampāo fosfato $\left(0,2 \mathrm{M} \mathrm{KH}_{2} \mathrm{PO}_{4}, 0,1 \mathrm{M} \mathrm{Na} \mathrm{HPO}_{4}\right.$, pH 6.5), $100 \mu \mathrm{L}$ de GSH (25 mM em $\mathrm{H}_{2} \mathrm{O}$ ), $40 \mu \mathrm{L}$ de CDNB (25 mM em etanol) e $683 \mu \mathrm{L}$ de $\mathrm{H}_{2} \mathrm{O}$. O tubo foi incubado a $37^{\circ} \mathrm{C}$ por 5 minutos e a seguir adicionaram-se $10 \mu \mathrm{L}$ da amostra contendo a enzima (lisado bacteriano ou a proteína pura). Após uma incubação de 5 minutos, o tubo foi colocado em gelo e procedeu-se à determinação da absorbância da amostra a $340 \mathrm{~nm}$.

\subsection{Precipitação seletiva}

\subsection{Precipitaçāo da proteína de fusāo GST-S3S4}

Bactérias contendo pGEX3X-S3S4 foram induzidas e lisadas por tratamento com lisozima e sonicação (como descrito nos itens 2.16.3.3.1 e 2.16.3.3.2). A diferentes alíquotas destes lisados foram adicionados os seguintes reagentes: $1 \%$ Triton ${ }^{\circ}-100,0,03 \%$ SDS, 10 
mM DTT e $0,03 \%$ SDS +10 mM DTT. As aliquotas foram incubadas a $37^{\circ} \mathrm{C}$ por 10 minutos e a seguir centrifugadas a 10.000 rpm por 20 minutos (rotor Sorvall SS-34). Os respectivos sedimentos e sobrenadantes foram analisados por eletroforese em gel de poliacrilamida Este experimento visou determinar a ação dos agentes acima sobre a solubilidade da proteina. .

\subsection{Ressolubilização da proteína de fusão GST-S3S4}

Sedimentos contendo a proteína de fusão foram ressuspensos e incubados por 5 minutos a $37^{\circ} \mathrm{C}$ nos seguintes tampōes de concentraçăo $50 \mathrm{mM}$, contendo $\mathrm{NaCl} 150 \mathrm{mM}$ : glicina $\mathrm{pH} 2,3$; acerato $\mathrm{pH} \mathrm{4,0;} \mathrm{cirrato} \mathrm{pH} 5,0$; fosfato $\mathrm{pH} 7,0$; Tris- $\mathrm{HCl} \mathrm{pH}$ 8.0; Tris- $\mathrm{HCl} \mathrm{pH}$ 9,0 ; bicarbonato $\mathrm{pH}$ 9,6; dietilamina $\mathrm{pH} 11,5$. Após a incubaçāo as amostras foram centrifugadas por 3 minutos em microcentrifuga ( $13.000 \mathrm{~g}$ ). Os sobrenadantes e sedimentos respectivos foram analisados por eletroforese em gel de poliacrilamida.

\subsection{Utilização das proteinas de fusão no diagnóstico sorologico da doença de Chagas}

\subsubsection{Radioimunoensaio em microplacas}

Foram utilizadas as proteínas produzidas pelo vetor pMSgtll e purificadas, por afinidade, em colunas de pAPTG-agarose (ver itens 2.16.2.3, 2.16.2.4 e 2.16.2.6) ou a proteina GST-S3S4, purificada por precipitaçào seletiva com $0,03 \%$ (p/v) SDS, seguida de ressolubilização em tampão $50 \mathrm{mM}$ trietanolamina pH 11,5. As proteínas em soluçāo de PBS foram aplicadas em poços de microplacas (Falcon $\# 9311$ ), em um volume de $50 \mu \mathrm{L}$. As microplacas foram cobertas com um plástico fino (Magipack ${ }^{8}$ ) e incubadas durante a noite a $4^{\circ} \mathrm{C}$ para permitir a adsorção dos antígenos. Em seguida, os poços foram lavados três vezes com PBS e bloqueados com PBS/BSA I\% por uma hora. Os soros humanos, diluidos em PBS/BSA $1 \%$, foram incubados por 2 horas em um volume de $100 \mu \mathrm{L}$ por poço. A seguir os poços foram lavados três vezes com PBS/Tween 20 0,05\%, três vezes com PBS e rebloqueados com PBS/BSA $1 \%$ por uma hora. Em seguida distribuíram-se volumes de $70 \mu \mathrm{L}$ por poço de uma soluçāo de proteína A radioiodada em PBS/BSA $1 \%$ (200.000 cpm/poço) e incubou-se por mais uma hora. Os poços foram novamente lavados três vezes com PBS/Tween 20 e três vezes com PBS, c deixados secar. A seguir os poços foram recortados e colocados em tubos de plástico (Beckman). A contagem foi feita em contador de radiação $\gamma$ (Beckman Gamma 5500). Em alguns soros de pacientes chagásicos agudos foi investigada a presença de IgM. Neste caso, após a incubação com o primeiro soro, lavagens e bloqueio, foi incluída uma incubação de uma hora com IgG de coelho anti-IgM humana (cadeia $\mu$ ), na diluição 1:500. As demais etapas subseqüentes foram idênticas às descritas acima. 


\subsubsection{ELISA}

Os dados de ELISA apresentados nesse trabalho foram obridos a partir de reagentes da Polychaco S.A.I.C. (Argentina) e gentilmente cedidos pelo Dr. Jorge Y'anovsky. Microplacas de plástico foram adsorvidas com $50 \mathrm{ng}$ da proteína $\beta$-gal-B13 como descrito no item anterior. Após a incubação com o soro, um segundo anticorpo conjugado a peroxidase de raiz forte foi utilizado. Empregou-se como cromogênio trimetilbenzidina. A reaçào foi interrompida com ácido sulfúrico e a absorbância foi dererminada a $450 \mathrm{~nm}$.

\subsubsection{Análise estatística}

Para a análise estatística dos dados sorológicos foi calculado o índice $\mathrm{k}$ (Kappa), descrito por Cohen (1960), que mede a proporção de acertos verdadeiros (número de acertos observados corrigido contra o número de acertos esperados ao acaso). Os acertos foram arribuidos tendo como base a prévia análise dos soros por técnicas sorológicas convencionais. Os índices $\mathrm{k}$ foram calculados, para cada anrigeno, de acordo com a fórmula $\kappa=(\mathrm{Po}-\mathrm{Pe}) /(1-\mathrm{Pe})$; onde Po é o número de acertos observados e Pe o número de acertos esperados ao acaso. Esse teste foi escolhido pela Organização Mundial da Saúde para um estudo multicêntrico de avaliaçăo de antígenos de $T$. cruzi no diagnóstico sorológico da doença de Chagas (Moncayo \& Luquetti, 1990).

\subsection{Ensaio de imuno-seleção}

2.18.1. Acoplamento de proteínas à resina de agarose ativada

As proteinas $\beta$-galactosidase, $\beta$-gal-Bl2 e $\beta$-gal-Bl3 foram purificadas por cromatografia de afinidade (ver item 2.16.2.6) e liofilizadas. Cada proteina ( $4 \mathrm{mg}$ ) foi ressuspensa em $1,2 \mathrm{~mL}$ de tampāo de acoplamento $(0,1 \mathrm{M}$ tampāo bicarbonato pH 8,$3 ; 0,5$ $\mathrm{M} \mathrm{NaCl}$ ) e dialisada durante a noite contra $500 \mathrm{~mL}$ do mesmo tampão. No dia seguinte, o volume de cada soluçāo, bem como sua absorbância a $280 \mathrm{~nm}$ foram medidos. Para o acoplamento utilizou-se a resina Sepharose $4 \mathrm{~B}$ ativada por brometo de cianogênio. $O$ método empregado seguiu as instruçóes do fabricante (Pharmacia). Cerca de $200 \mathrm{mg}$ da resina foram inchados em $70 \mathrm{~mL}$ de uma solução $1 \mathrm{mM}$ de $\mathrm{HCl}$ por 15 minutos. A suspensāo foi filtrada e, no próprio filtro, lavou-se a resina com mais $70 \mathrm{~mL}$ da solução de $\mathrm{HCl}$. A seguir a resina foi lavada com $4 \mathrm{~mL}$ de tampāo de acoplamento e transferida para um tubo com 1,2 mL da solução da proteína em tampāo de acoplamento. Procedeu-se a uma incubação de 3,5 horas, à temperarura ambiente, sob agitação leve. A resina foi então 
novamente filtrada e lavada com $2 \mathrm{~mL}$ de tampão de acoplamento, para eliminar o excesso de proteína nāo ligada. As soluçōes recolhidas nesta filtração tiveram seu volume e absorbância a $280 \mathrm{~nm}$ determinados. Estes dados foram comparados com os obtidos na solução de proteína anterior ao acoplamento, a fím de se determinar a eficiência da reação. Em seguida a resina foi ressuspensa em $6 \mathrm{~mL}$ de $1 \mathrm{M}$ etanolamina e incubada por uma hora e meia, a fim de bloquear os grupos ativos remanescentes. Finalmente, lavou-se a resina, sob filtração, com $40 \mathrm{~mL}$ de tampão de acoplamento, $40 \mathrm{~mL}$ de solução tampão acetato 0,1

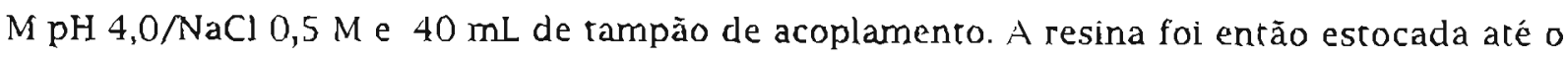
uso em solução de $\mathrm{NaCl} 0,15 \mathrm{M} \operatorname{com} 0,02 \%(\mathrm{p} / \mathrm{v})$ de timerosal, a $4^{\circ} \mathrm{C}$.

\subsubsection{Purificação de IgG a partir de soros de pacientes chagásicos}

Foram feitos testes de RLA (ver item 2.17.1) para várias amostras de soros de pacientes chagásicos crônicos, a fim de se determinar sua reatividade frente a um lisado rotal de formas tripomastigotas. O soros mais reativos foram selecionados e testados em RIA contra os antigenos B12 e B13 puros. Os soros positivos foram reunidos e urilizados para a purificação de IgG, partindo-se de um volume rotal de $50 \mathrm{~mL}$. Como controle, também foi utilizada uma mistura de soros humanos normais. A purfficação foi reita por "salting-out". A cada amostra de soros adicionou-se sulfato de sódio na concentraçăo de 18 g/100 mL. A amostra foi incubada por 30 minutos à temperarura ambiente, sob agitaçăo leve. Em seguida centrifugou-se a 1.000 g por 15 minutos e o sedimento foi ressuspenso em tampāo $0,1 \mathrm{M}$ fosfato $\mathrm{pH} 8,0$ para um volume final de $30 \mathrm{~mL}$. Seguiram-se duas precipitações com sulfato de sódio, na proporção de $12 \mathrm{~g}$ por $100 \mathrm{~mL}$ de solução. $\mathrm{O}$ sedimento final foi ressuspenso no rampào fosfato descrito acima, em um volume final de $15 \mathrm{~mL}$. A solução foi dialisada durante a noite contra 6 litros do mesmo tampão a $4^{\circ} \mathrm{C}$. A concentração protéica foi medida pelo método de Hartree (1972), como descrito no item 2.22 .

2.18.3. Cromatografia de afinidade para obtenção de anticorpos monoespecíficos

Para a cromatografia de afinidade procedeu-se a uma diálise de $117 \mathrm{mg}$ de $\lg \mathrm{G}$ de pacientes chagásicos contra tampão $10 \mathrm{mM}$ fosfato $\mathrm{pH} 8,0 / 150 \mathrm{mM} \mathrm{NaCl}$. As resinas acopladas às proteínas B12, B13 c $\beta$-galactosidase foram cquilibradas cm PBS $e$ empacotadas em colunas. A amostra de IgG chagásica foi submetida a uma cromatografia sequencial nas colunas, de $\beta$-galactosidase, B12 e B13. A solução de anticorpos foi recirculada 3 vezes na primeira coluna, o eluato transferido para a próxima coluna e assim por diante. Após a passagem das amostras, as colunas foram lavadas com $10 \mathrm{~mL}$ de tampão $10 \mathrm{mM}$ fosfato $\mathrm{pH} 8,0 / 0,5 \mathrm{M} \mathrm{NaCl}$. A eluição foi feita com $10 \mathrm{~mL}$ de 
tampāo 0,2 M glicina pH 2,3/0,15 M NaCl, coletando-se frações de $1 \mathrm{~mL}$. Os eluatos foram imediatamente neutralizados com $1 \mathrm{M}$ Tris. $\mathrm{Cl} \mathrm{pH} 8,8$ e acrescidos de BSA para $1 \%(\mathrm{p} / \mathrm{v}$ ) final. As colunas foram lavadas com $5 \mathrm{~mL}$ de $0,05 \mathrm{M}$ dietilamina $\mathrm{pH}$ 11,6 e reequilibradas em PBS pH 8,0.

2.19. Eletroforese unidimensional de proteínas em gel de poliacrilamida contendo SDS (SDSPAGE)

Foi utilizado o sistema de gel descontínuo de Laemmli (1970) contendo um gel de empilhamento e um de separação. Foram utilizadas as seguintes soluções para essa técnica:

-Solução estoque de acrilamida para gel de separação (A) - 30\% (p/v) acrilamida; $0,8 \%$ (p/v) bisacrilamida.

-Solução tampão para gel de separação $4 x$ concentrada (B) - 1,5 M Tris- $\mathrm{HCl}$ pH 8,8; $0,4 \%(\mathrm{p} / \mathrm{v})$ SDS.

-Solução estoque de acrilamida para gel de empilhamento $(\mathrm{C}) \cdot 30 \%(\mathrm{p} / \mathrm{v})$ acrilamida; $1,6 \%(\mathrm{p} / \mathrm{v})$ bisacrilamida.

-Solução tampāo para gel de empilhamento 4 x concentrada (D) $-0,5 \mathrm{M}$ Tris- $\mathrm{HCl}$ pH 6,$8 ; 0,4 \%(\mathrm{p} / \mathrm{v})$ SDS.

Todas as soluções acima foram filtradas após o preparo e estocadas em frascos escuros a $4^{\circ} \mathrm{C}$.

-Gel de empilhamento - 3\% de acrilamida (da solução estoque $C$ ); lx solução $D_{;}$ 0,03\% (p/v) persulfato de amônio; 0,2\% (v/v) TEMED.

-Gel de separação - 7,5\% acrilamida (da solução estoque $A$ ); lx soluçāo B; $0,03 \%(p / v)$ persulfato de amônio; $0,1 \%(v / v)$ TEMED.

-Tampão de corrida - 25 mM Tris-HCl pH 8,6; $192 \mathrm{mM}$ glicina; 0,1\% (p/v) SDS.

-Tampāo de amostra de proteína $2 x$ concentrado - $125 \mathrm{mM}$ Tris $\mathrm{HCl}$ pH 6.8; 4\% SDS $(p / v) ; 5 \%$ 2-mercaptoetanol (v/v); 20\% glicerol $(v / v) ; 0,02 \%(p / v)$ azul de bromofenol.

-Mistura de vaselina/parafina - $50 \mathrm{~g}$ de vaselina e $2 \mathrm{~g}$ de parafina. A mistura foi aquecida, homogenejzada e distribuida em seringas de plástico.

-Solução de azul de Coomassie - 0,3\% (p/v) azul de Coomassie R-250; 50\% (v/v) metanol; $10 \%(v / v)$ ácido acético.

-Solução de descoloração - 10\% (v/N) etanol; 7\% (v/N) ácido acético.

Para a montagem do gel foram utilizadas duas placas de vidro de $14,5 \times 16,5 \mathrm{~cm}$ e espaçadores de acrílico com 1,5 mm de espessura. A vedaçāo das placas e espaçadores foi feita com uma mistura de vaselina e parafina (ver acima). Aplicou-se então a solução de gel de separação, até o gel atingir uma altura de $8,5 \mathrm{~cm}$. Em seguida borrifou-se 
cuidadosamente uma soluçāo 0,1\% de SDS formando uma camada de cerca de $1 \mathrm{~cm}$ sobre o gel. Após a polímerizaçāo a soluçāo de SDS foj removida e o gel lavado com água destilada. A seguir foi aplicada a solução de gel de empilhamento, perfazendo uma altura de cerca 2,5 $\mathrm{cm}$, e posicionado o pente. As amostras de proteína, previamente dissolvidas em rampão de amostra, foram fervidas por 3 minutos e aplicadas no gel. Como marcadores de peso molecular foram utilizadas as seguintes proteínas: miosina (205 kDa); $\beta \cdot$ galacrosidase (1 16 $\mathrm{kDa})$; fosforilase b $(97,4 \mathrm{kDa})$; albumina (66 kDa), ovalbumina (43 kDa) e anidrase carbônica (29 kDa). A eletroforese foi feita em tampão de corrida a $30 \mathrm{~mA}$, até o azul de bromofenol, presente no tampão de amostra, atingir o fundo do gel. O gel de separação foi então removido e mergulhado na soluçāo de azul de Coomassie que, além de corar o gel, também promove sua fixaçāo. A cuba contendo o gel foi aquecida no forno de microondas por 3 minutos. Em seguida a solução do corante foi removida e substituída pela solução de descoloraçāo. O gel foi descorado sob agitação leve, fazendo-se várias trocas da soluçāo de descoloraçāo. Finalmente, o gei foi colocado sobre um papel mata-borrāo, coberto com um plástico fino e sêco, sob vácuo, em aparelho secador de géis (BioRad) a $80^{\circ} \mathrm{C}$.

\subsection{Ensaio de Western blot}

\subsubsection{Transferência das proteínas para filtro de nitrocelulose}

As proteinas foram separadas em SDS-PAGE como descrito no item 2.19, com a exceção que foram usados espaçadores mais finos, com $1 \mathrm{~mm}$ de espessura. Após a eletroforese as placas de vidro foram separadas e o gel de empilhamento removido. 0 procedimento adotado para a transferência seguiu a técnica de Towbin et al. (1979) com algumas modificações (Burnetre, 1981). O gel de separação foi colocado sobre um conjunto de 5 folhas de papel de filtro previamente molhadas em tampāo de transferência (20 mM Tris- $\mathrm{HCl} \mathrm{pH} 8,3 ; 192 \mathrm{mM}$ glicina; $20 \%(\mathrm{v} / \mathrm{v})$ metanol). Por cima do gel foi colocado um filtro de nitrocelulose e mais 5 folhas de papel de filtro. O conjunto foi montado em uma cuba vertical de transferencia, tendo-se o cuidado de remover todas as bolhas de ar. A cuba foi totalmente preenchida com tampão e a transferência foi realizada sob tensāo constante a 50 $\checkmark$ por 18 horas.

\subsubsection{Coloração do filtro de nitrocclulose}

Após a transferência, o filtro de nitrocelulose foi corado por 3 minutos com uma solução de Ponceau $S(0,2 \%$ p/v Ponceau $S ; 1,0 \%$ v/v ácido acético). Após a coloração o filtro foi colocado sobre uma folha de papel de filtro para melhor visualização das bandas de proteínas. A posiçāo das bandas do padrão de peso molecular foi demarcada no filtro com 
um lápis. Finalmente, o filtro foi lavado várias vezes com TBS até o total descoramento. Na última lavagem adicionou-se timerosal na concentração final de $0,01 \% \mathrm{p} / \mathrm{v}$ e o filtro foi guardado úmido, selado em um saco plástico, a $4^{\circ} \mathrm{C}$ aré o momento do uso.

\subsubsection{Reação com anticorpos e revelação}

\subsubsection{Revelação imunoenzimática}

Os soros de coelhos foram urilizados na diluiçāo l:100 e a fração de imunoglobulina chagásica, obtida por imuno-seleção (ver irem 2.18), usada diretamente. Os filtros foram lavados 2 vezes em TBS e bloqueadas em TBS/BSA 2\% ou em TBS/3\% leite desnatado $\left(\right.$ Molico ${ }^{2}$ ) por 1 hora. Os anticorpos, diluídos em TBS/BSA 1\%, foram incubados com as tiras durante a noite a $4^{\circ} \mathrm{C}$. No dia seguinte as tiras foram submetidas a três lavagens de 10 minutos com TBS e um novo bloqueio com TBS/Molico 3\%. O anticorpo secundário, conjugado com peroxidase de raiz forte, foi diluído l:500 em TBS/Molico 3\% e incubado com as tiras de nitrocelulose por 2 horas. As tiras foram entāo lavadas três vezes com TBS e rraradas com uma solução recém-preparada de revelador $(6 \mathrm{mg}$ de 4 -cloro- $\alpha$-naftol; $2 \mathrm{~mL}$ de metanol; $10 \mathrm{~mL}$ de TBS ; $10 \mathrm{~mL}$ de $\mathrm{H}_{2} \mathrm{O}_{2}$ ). A revelação foi intertompida com água destilada.

\subsubsection{Revelaçāo com proteína A radioariva}

O filltro de nitrocelulose, após a incubação com o soro, fol submetido a 5 lavagens de 10 minutos com TBS/Tween 20 0,05\% e novo bloqueio de 30 minutos com TBS/BSA 1\%. 0 filtro foi então incubado por 1 hora com proteína A marcada com ${ }^{125} \mathrm{I}$, diluida em TBS/BSA $1 \%\left(4 \times 10^{5} \mathrm{cpm} / \mathrm{mL}\right)$. Seguiram-se mais 5 lavagens de 10 minutos com TBS/Tween 20 $0,05 \%$. O filtro foi sêco e fixado em papel mata-borrão. A auto-radiografja foi feita mediante exposiçāo de uma chapa radiográfica por 18 a 36 horas, a $-70^{\circ} \mathrm{C}$ com um intensificador de sinal.

\subsection{Ensaio de imunoprecipitaçāo}

\section{2 l.1. Marcação radioativa da superfície de parasitas}

Formas epimastigotas e tripomastigotas de cultura de tecido, da cepa $Y$ de $T$, cruzi, tiveram as proteínas de sua superficie marcadas com iodo radioativo segundo o protocolo de Zingales et al. (1982), modificado de Markwell \& Fox (1978). Os epimastigotas foram lavados três vezes, por centrifugação, com PBS e os tripomastigotas com meio DME. A radioiodaçāo foi feita pela incubação de $10^{8}$ células em $0,5 \mathrm{~mL}$ de PBS contendo $250 \mu \mathrm{Ci}$ de 
$\mathrm{Na}^{131} \mathrm{I}$, a $4^{\circ} \mathrm{C}$ por 10 minutos, em rubos previamente revestidos com $20 \mu \mathrm{g}$ de Iodogen ${ }^{8}$ (1,3,4,6-tetracloro-3 $\alpha, 6 \alpha$-difenilglicoluril - Pierce Chemical Co.). Os parasitas foram lavados duas vezes em PBS (epimastigotas) ou DME (tripomastigotas), por centrifugação, a $3.000 \mathrm{~g}$ por 10 minutos.

\subsubsection{Precipitação dos antígenos}

A imunoprecipitaçāo dos parasitas marcados foi realizada segundo o método de Kessler (1975) adaptado por Zingales et al. (1982). Os parasitas ( $10^{8}$ células) foram lavados com PBS e ressuspensos em $150 \mu \mathrm{L}$ de tampào de lise $(10 \mathrm{mM}$ Tris- $\mathrm{HCl}$ pH 7,5; $1 \%(\mathrm{v} / \mathrm{v})$ Nonidet P-40; 1 mM PMSF; 1 mM TLCK; 2,8 U/mL aprotinina). Após uma incubaçāo de 15 minutos a $4^{\circ} \mathrm{C}$, a soluçāo foi centrifugada a $10.000 \mathrm{~g}$ por 10 minutos a $4^{\circ} \mathrm{C}$. Aliquotas do sobrenadante (correspondentes a $3 \times 10^{7}$ parasitas) foram diluidas com um volume igual de tampão contendo $100 \mathrm{mM}$ Tris- $\mathrm{HCl}$ pH 7,5; $10 \mathrm{mM}$ EDTA. $300 \mathrm{mM} \mathrm{NaCl} ; 0,02 \%$ (p/v) azida sódica, e incubadas seqüencialmente com soro normal, anti- $\beta$-galactosidase, anti- $\beta$-gal-Bl 2 e anti- $\beta$-gal-B13. As incubações variaram de 1 a 2 horas a $4^{\circ} \mathrm{C}$. Os imunocomplexos foram adsorvidos pela adição de $70 \mu \mathrm{L}$ de uma suspensão $10 \%$ de Staphyloccocus aureus da cepa Cowan I (inativado pelo calor e fixado com formalina). Após uma incubação de 30 minutos à temperatura ambiente, a amostra foi centrifugada. Os precipitados foram lavados duas vezes com solução tampão $50 \mathrm{mM}$ Tris- $\mathrm{HCl}$ pH 7,5; $5 \mathrm{mM}$ EDTA; $150 \mathrm{mM} \mathrm{NaCl} ; 0,05 \%(v / v)$ Nonidet $\mathrm{P}-40 ; 1 \mathrm{mg} / \mathrm{mL}(\mathrm{p} / \mathrm{v}) \mathrm{BSA} ; 0,01 \%(\mathrm{p} / \mathrm{v})$ azida sódica. A seguir procedeu-se a mais uma lavagem com uma soluçāo contendo $10 \mathrm{mM}$ Tris- $\mathrm{HCl}(\mathrm{pH} 8,7) ; 0,3 \mathrm{M} \mathrm{NaCl} ; 0,1 \%$ (p/v) SDS e $0,05 \%(\mathrm{p} / \mathrm{v})$ Nonidet $\mathrm{P}-40$, a fim de reduzir as precipiraçōes inespecificas. Os precipitados foram ressuspensos em $70 \mu \mathrm{L}$ de tampāo de amostra de cletroforese e fervidos por 5 minutos. Após uma centrifugaçāo, os sobrenadantes foram aplicados em gel de poliacrilamida, e submetidos a uma eletroforese em gel de poliacrilamida (Laemmli, 1970). Os géis foram corados, sêcos e expostos com um filme de raios $X$ com uma placa intensificadora a $-70^{\circ} \mathrm{C}$.

\subsection{Dosagem de proteína}

Utilizou-se o método de Hartree (1972) que é uma modificaçāo do protocolo de dosagem de proteínas de Lorvry (1951). Entre as vantagens destacam-se uma maior intensidade de coloração e uma proporcionalidade direta em uma maior faixa de concentração protéica (entre 15 a $100 \mu \mathrm{g}$ ). Para esse método foram utilizadas as soluções descritas abaixo: 
Solução A - 2 g de tartarato de sódio e potássio e $100 \mathrm{~g} \mathrm{Na}_{2} \mathrm{CO}_{3}$ foram dissolvidos em $500 \mathrm{~mL}$ de $1 \mathrm{~N} \mathrm{NaOH}$ e em seguida diluidas para 1 litro.

Solução B - 2 g de tartarato de sódio e potássio e $\mathrm{l} g$ de $\mathrm{CuSO}_{4} .5 \mathrm{H}_{2} \mathrm{O}$ foram dissolvidos em $90 \mathrm{~mL}$ de água e adicionados de $10 \mathrm{~mL}$ de $1 \mathrm{~N} \mathrm{NaOH}$.

Solução C - 1 volume do reagente de Folin-Ciocalteau foi diluído com 15 volumes de água no momento do uso.

Para o ensaio as amostras das proteínas, diluídas em $1 \mathrm{~mL}$ de água, foram dispensadas em tubos de ensaio, adicionadas de $0,9 \mathrm{~mL}$ da solução $A$ e incubadas em um banho de água a $50^{\circ} \mathrm{C}$ por 10 minutos. Os tubos foram deixados esfriar à temperatura ambiente e adicionaram-se $0,1 \mathrm{~mL}$ da soluçāo B. Após uma incubação de 10 minutos à temperatura ambiente, foram adicionados $3 \mathrm{~mL}$ da solução $C$ em cada tubo, homogeneizando-se rapidamente. Os tubos foram entāo incubados a $50^{\circ} \mathrm{C}$ por mais 10 minutos e deixados esfriar. As absorbâncias foram medidas em um comprimento de onda de 650 nm. Como branco foi utilizada uma amostra de água e, como padrão, uma solução de albumina com uma concentraçāo de $50 \mu \mathrm{g} / \mathrm{mL}$. Ambos os controles foram tratados como descrito acima. A conversão das absorbâncias para $\mathrm{mg} / \mathrm{mL}$ foi feita em relação a uma solução-padrão de albumína $1 \mathrm{mg} / \mathrm{mL}$ que apresenta uma D. $0.600=0,66$.

\subsection{Ensaio de Southern blot}

\subsubsection{Transferência do DNA para membrana de nylon}

Após a corrida eletroforética o gel foi visualizado sob luz UV e fotografado. Em seguida foí lavado por 15 minutos em soluçāo $0,25 \mathrm{~N}$ de $\mathrm{HCl}$ para hidrolisar parcialmente o DNA e facilitar a transferência de fragmentos grandes. O gel foi entāo tratado com solução $0,5 \mathrm{~N} \mathrm{NaOH}$ e $1,5 \mathrm{M} \mathrm{NaCl}$ por 30 minutos, para promover a desnaturaçāo do DNA. Procedeu-se à neutralização por meio de lavagem com solução l $\mathrm{M}$ Tris- $\mathrm{HCl}$ pH 8,0/1,5 M $\mathrm{NaCl}$ por 30 minutos. Todas as lavagens foram feitas com agitação suave. A transferência foi feita de forma semelhante ao método de Southern (1975). Utilizou-se um reservatório com tampão SSC 20x e uma ponte de filtro Whatman 3MM. O gel foi colocado invertido sobre o filtro e por cima colocou-se uma membrana de nylon Hybond $\mathrm{N}^{\otimes}$. A membrana foi coberta por um filtro whatman 3MM, uma pilha de folhas de papel toalha e um peso de cerca de $1,5 \mathrm{~kg}$. A transferência foi feita por um periodo de 16 a 18 horas à temperatura ambiente. Alternativamente, o DNA foi transferido para a membrana de nylon sob vácuo (5 a $10 \mathrm{cmHg}$ ), por 90 minutos, utilizando-se o aparelho Trans-Vac ${ }^{\ominus}$ TE 80 da Hoefer. Após a transferência a membrana de nylon foi lavada em solução de acetato de amônio $1 \mathrm{M}$ por alguns segundos e sêca. A membrana foi entāo revestida com plástico fino (tipo Magipack 
e colocada sobre um transiluminador de UV (330 nm), com a face do DNA voltada para a lâmpada. Após uma exposição de 3 a 5 minutos, a membrana foi guardada entre dois papéis de filtro revestidos de papel alumínio e estocada a $-20^{\circ} \mathrm{C}$ até o momento de uso.

\subsubsection{Hibridização das sondas com a membrana}

As membranas de nylon foram colocadas dentro de sacos plásticos e submetidas à pré-hibridizaçāo com $0,1 \mathrm{~mL} / \mathrm{cm}^{2}$ de tampāo de hibridizaçâo ( $3 \times 55 \mathrm{C} ; 1 \mathrm{mM}$ EDTA; $0,1 \%$ p/v SDS; 0,1\% p/v Ficoll; 0,1\% p/v PVP; $100 \mu \mathrm{g} / \mathrm{mL}$ DNA de esperma de salmão), a $67^{\circ} \mathrm{C}$ por 90 minutos. Alternativamente, os filtros de nitrocelulose foram colocados em rubos de vidro da estufa de hibridização HybAid ${ }^{\circledast}$ e pré-hibridizados cada um com $20 \mathrm{~mL}$ de solução. Para a hibridizaçāo, as sondas foram desnaturadas em banho de água fervente por 7 minutos e diluídas em rampão de hibridização para $10^{6} \mathrm{cpm}$ TCA precipitáveis $/ \mathrm{mL}$. A hibridização foi realizada a $67^{\circ} \mathrm{C}$ durante a noite. Após a hibridização, as membranas foram submetidas a uma lavagem em solução SSC 3x/SDS 0,1\% por l hora, uma lavagem em SSC $1 x /$ SDS $0,1 \%$ por uma hora e duas lavagens em SSC $0,1 \times / S D S 0,1 \%$, de 30 minutos cada. Todas as lavagens foram cfetuadas a $67^{\circ} \mathrm{C}$ com tampões pré-aquecidos. A membrana úmida foi entāo colocada sobre um plástico transparente nígido e recoberta com um plástico fino (Magipack). A exposição com uma chapa radiográfica foi feita com um ou dois intensificadores de sinal a $\cdot 70^{\circ} \mathrm{C}$ por 18 a 36 horas.

\subsection{Ensaio de Northem blot}

\subsubsection{Eletroforese de RNA em géis de agarose/formaldeído}

Foi preparado um gel de agarose em concentraçōes variando entre $0,7 \%$ a $1,2 \%$ $(p / v)$, escolhida em funçăo da faixa ótima de resolução desejada. A agarose foi fundida em água bidestilada em um fomo de microondas. Quando a temperatura diminuiu para $60^{\circ} \mathrm{C}$, adicionaram-se tampão MOPS $10 x$ autoclavado para uma concentração final de $1 \times$ e formaldeido $37 \%(\mathrm{p} / \mathrm{v}$ ) para $0,66 \mathrm{M}$ final. Os sedimentos de RNA (20 $\mu \mathrm{g}$ de RNA total ou 2 $\mu g$ de RNA poli $A^{+}$) foram ressuspensos em $20 \mu$ de tampāo de amostra de RNA (50\% v/v formamida deionizada; $6,5 \% \mathrm{v} / \mathrm{v}$ formaldeido; tampão MOPS $\mathrm{lx}$ ). As amostras foram então aquecidas a $65^{\circ} \mathrm{C}$ por 15 minutos e $\mathrm{cm}$ seguida adicionaram-se $2 \mu \mathrm{l}$ de solução corante (50\% $\mathrm{v} / \mathrm{v}$ glicerol; $0,4 \% \mathrm{p} / \mathrm{v}$ azul de bromofenol; $0,4 \% \mathrm{p} / \mathrm{v}$ xilenocianol; $1 \mathrm{mM}$ EDTA).

Cada amostra foi rapidamente colocada em gelo até o momento de ser aplicada no gel. A corrida eletroforética foi realizada em tampão MOPS lx a $120 \mathrm{~mA}$, e interrompida quando o azul de bromofenol atingiu $3 / 4$ do gel. Após a eletroforese o gel foi lavado em água destilada em vários periodos de 10 minutos. A regiāo do gel contendo os marcadores 
de peso molecular foi corada com uma soluçāo de $0,5 \mu \mathrm{g} / \mathrm{mL}$ de brometo de etídio, por 45 minutos, e descorada por uma hora em água destilada. Como marcadores foram utilizados os RNAs ribossomais de células LLC-MK2, de E, coli e de $T$. cruzi. Alternativamente empregou-se como marcador um DNA de $\lambda$ cI857 digerido com HindIII e marcado com $[\alpha-32$ P]dATP. Neste caso o marcador foi transferido para a matriz de nitrocelulose junto com as demais amostras.

\subsubsection{Transferência do RNA}

O gel foi tratado segundo o mérodo descrito por Sambrook et al. (1989). Foram realizadas várias lavagens de 5 minutos em água destilada. Em seguida o gel foi tratado com uma solução $\mathrm{NaOH} 50 \mathrm{mM} / \mathrm{NaCl} 10 \mathrm{mM}$ por 45 minutos para se obter uma hidrólise alcalina parcial. Este procedimento visa melhorar a eficiência da transferência de moléculas de RNA de alto peso molecular. O gel foi posteriormente neutralizado por 45 minutos em uma solução Tris- $\mathrm{HCl} 0,1 \mathrm{M}$ pH 7,5. Finalmente colocou-se o gel em uma solução SSC $15 x$ por 1 hora. A transferência do RNA para um filtro de nitrocelulose (Hybond $C^{\otimes}$ ) ou de nylon (Hybond $\mathrm{N}^{\otimes}$ ) foi feita de forma semelhante ao método de Southern (1975) conforme descrito no item 2.23. Utilizou-se a solução SSC $15 x$ para a transferência, por um periodo de 16 a 18 horas à temperatura ambiente. Alternativamente, o RNA foi transferido para uma membrana de nitrocelulose, sob vácuo (5 a $10 \mathrm{cmHg}$ ), por 90 minutos, utilizando-se o aparelho da Trans-Vac TE 80 da Hoefer. A seguir o filtro foi lavado brevemente em soluçāo SSC 3x e sêco ao ar. A fixação do RNA na maniz foi feita através de uma incubação em forno a $80^{\circ} \mathrm{C}$ por 2 horas.

\subsubsection{Hibridização das sondas com as membranas}

As membranas foram colocados em tubos de vidro da estufa de hibridizaçāo HybAid ${ }^{\circledast}$ e pré-hibridizados cada um com $20 \mathrm{~mL}$ de solução de hibridização para Northern blot ( $5 \times$ SSPE; $50 \%$ v/v formamida; $5 \times$ solução Denhardt; 0,1\% p/v SDS; 0,1 mg/mL DNA de esperma de salmāo) a $42^{\circ} \mathrm{C}$ por 2 horas. A seguir esta soluçāo foi substituída por $10 \mathrm{~mL}$ de solução de hibridização nova contendo sulfato de dextrana $10 \%(\mathrm{p} / \mathrm{v})$ e a sonda de DNA (5$10 \times 10^{6} \mathrm{cpm}$ ) previamente fervida por 7 minutos. Os tubos contendo as membranas foram incubados sob rotação durante a noite a $+2^{\circ} \mathrm{C}$. No dia seguinte as membranas sofreram 2 lavagens de 15 minutos a $42^{\circ} \mathrm{C}$ com $25 \mathrm{~mL}$ de solução SSC $2 x / \mathrm{NaPPi} 1 \mathrm{mM}$, e 4 lavagens de 30 minutos a $42^{\circ} \mathrm{C}$ com $25 \mathrm{~mL}$ de solução SSC 0,1 x/SDS $0,1 \%$. Em seguida procedeu-se à exposiçāo das membranas com filmes de raios $X$ a $-70^{\circ} \mathrm{C}$, com uma ou duas placas intensificadoras de sinal, por 18 a 36 horas a $-70^{\circ} \mathrm{C}$. 


\subsection{Seqüenciamento de DNA}

2.25.1. Digestāo unidirecional do DNA com Exonuclease III

Com o objetivo de seqüenciar inteiramente fragmentos de DNA com um tamanho superior ao limite de resolução de um gel de seqüenciamento (cerca de 300 pares de bases), foi utilizado o protocolo de Henikoff (1987) com algumas modificaçōes (Sambrook et al. 1989), a partir do sistema Erase-a-Base (Promega). Uma massa de $20 \mu \mathrm{g}$ de DNA foi digerida com duas enzimas de restrição. Uma das enzimas tem um sitio de clivagem próximo ao inserto, que resulta em uma extremidade de fita simples 5' protuberante, enquanto a outra enzima cliva mais próximo ao vetor, deixando uma extremidade de fita simples $3^{\prime}$ protuberante com quatro bases. A extremidade $3^{\prime}$ protuberante é resistente à açāo da Exonuclease III, de forma que a digestāo é unidirecional.

Para esse protocolo foram utilizadas as seguintes soluçōes:

-Tampāo de Exonuclease III 10x concentrado - $660 \mathrm{mM}$ Tris- $\mathrm{HCl}$ pH 8,0; 6.6. mM $\mathrm{MgCl}_{2}$.

-Tampão de nuclease SI 7.4x-0,3 M acetato de potássio pH 4,6;2,5 M NaCl; $10 \mathrm{mM}$ $\mathrm{ZnSO}_{4} ; 50 \%(\mathrm{v} / \mathrm{v})$ glicerol.

-Mistura de nuclease S1 (para 25 pontos de cinética) - $172 \mu \mathrm{L}$ água deionizada; $27 \mu \mathrm{L}$ tampão de nuclease $S 17,4 x ; 60 \mathrm{U}$ nuclease $S 1$.

-Tampāo de término de S1 - 0,3 M Tris base; 0,05 M EDTA.

-Tampão de Klenow - $20 \mathrm{mM}$ Tris- $\mathrm{HCl}$ pH 8,0; $100 \mathrm{mM} \mathrm{MgCl}_{2}$.

-Mistura de Klenow - $30 \mu \mathrm{L}$ tampão de Klenow; 3-5 U de fragmento Klenow da DNA polimerase.

-Tampão de ligase $10 \times$ concentrado - $500 \mathrm{mM}$ Tris- $\mathrm{HCl} \mathrm{pH} 7,6 ; 100 \mathrm{mM} \mathrm{MgCl} ; 10$ mM ATP.

-Mistura de ligase - $790 \mu \mathrm{L}$ água deionizada; $100 \mu \mathrm{L}$ tampão de ligase $10 \mathrm{x} ; 100 \mu \mathrm{L}$ 50\% PEG; $10 \mu[100$ mM DTT; SU T4 DNA ligase.

O DNA foi extraido com fenol e clorofórmio e precipitado com acetato de sódio 0,3 $M$ final e 2,5 volumes de etanol a $-20^{\circ} \mathrm{C}$ durante a noite. No dia seguinte o tubo foi centrifugado a 13.000 g por 15 minutos e o scdimento lavado com etanol $70 \%$, sêco ao ar e ressuspenso em $60 \mu \mathrm{L}$ de tampão de Exonuclease III lx concentrado. Um total de 25 tubos Eppendorf ${ }^{\circledast}$ foram adicionados de $7,5 \mu \mathrm{L}$ de mistura de nuclease $\mathrm{Sl}$ e colocados em gelo. $\mathrm{O}$ tubo contendo o DNA foi incubado a $37^{\circ} \mathrm{C}$ por 5 minutos e adicionado de $500 \mathrm{U}$ de Exonuclease III. Foram removidas aliquotas de $2,5 \mu \mathrm{L}$ em intervalos de 30 segundos, as quais foram transferidas para os tubos com a mistura S1. Após a transferência do conteúdo 
do último tubo, os tubos com Sl foram incubados à temperatura ambiente por 30 minuros. A reação foi interrompida pela adição de l $\mu \mathrm{L}$ de soluçāo de término de 51 e posterior incubação a $70^{\circ} \mathrm{C}$ por 10 minutos. Para a visualização do resultado da digestão por Exonuclease III, alíquoras de $2 \mu \mathrm{L}$ foram aplicadas em um gel de agarose. O restante das amostras foi transferido para um banho a $37^{\circ} \mathrm{C}$ e adicionado de $1 \mu \mathrm{L}$ de mistura Klenow. Após uma incubação de 2 a 5 minutos, foi dispensado $1 \mu \mathrm{L}$ de soluçāo de dNTP $(0,125 \mathrm{mM}$ de cada) e os tubos foram incubados por mais 5 minutos a $37^{\circ} \mathrm{C}$. A seguir os tubos foram removidos à temperatura ambiente, adicionados de $40 \mu \mathrm{L}$ de mistura de ligação e incubados por uma hora a $37^{\circ} \mathrm{C}$. A transformaçāo foi feita na hospedeira JMl 09 conforme descrito no item 2.15.5, utilizando $10 \mu \mathrm{L}$ de cada amostra.

\subsubsection{Seqüenciamento de DNA de fita simples}

\subsubsection{Preparação dos moldes de DNA de fitas simples}

Placas brancas de fagos, obtidas na transfecçāo de bactérias competentes, foram removidas com as pontas de palitos de dente estéreis. Cada palito foi colocado em um tubo contendo 1,5 mL de caldo 2.TY e uma diluição l:100 de uma cultura fresca de jM101. Os tubos foram incubados sob vigorosa agitaçāo a $37^{\circ} \mathrm{C}$ por 4 horas. Cada cultura foi transferida para um tubo Eppendorf ${ }^{\oplus}$ e centrifugada por 5 minutos à temperatura ambiente. Os sobrenadantes foram transferidos para novos tubos e adicionaram-se $150 \mu \mathrm{L}$ de uma solução 20\% PEG 8000 (p/v)/2,5 M NaCl. Após homogeneização e uma incubação de 15 minutos à temperatura ambiente, os tubos foram centrifugados por 15 minutos na mesma temperatura. Os sobrenadantes foram desprezados e os tubos novamente centrifugados por 1 minuto. Com o auxílio de um pipeta Pasteur de ponta bem fina aspirouse o sobrenadante remanescente. O precipitado contendo os fagos foi ressuspenso em 100 $\mu \mathrm{L}$ de $\mathrm{TE}$ e extraído com $50 \mu \mathrm{L}$ de fenol saturado sob vigorosa agitação durante 30 segundos. Adicionaram-se para cada tubo $10 \mu \mathrm{L}$ de acetato de sódio $(3 \mathrm{M}, \mathrm{pH} 5,3)$ e 2,5 volumes de etanol, incubando-se durante a noite a $-20^{\circ} \mathrm{C}$. A seguir os rubos foram centrifugados por 20 minutos a $4^{\circ} \mathrm{C}$ e o DNA precipitado foi lavado 2 vezes com etanol $80 \%$, sêco sob vácuo e ressuspenso em $30 \mu \mathrm{L}$ de TE.

\subsubsection{Reação de seqüenciamento}

O seqüenciamento de DNA de fita simples foi feito em microplaca de plástico (Falcon \#9311) utílizando como polimerase o fragmento Klenow. As reaçōes de seqüenciamento foram feitas pelo método de terminação de cadeia de Sanger (1977). Abaixo estão apresentadas as soluçōes utilizadas: 
-TM - $100 \mathrm{mM}$ Tris- $\mathrm{HCl}$ pH 8,5; $50 \mathrm{mM} \mathrm{MgCl}$.

-Solução mistura de enzima - $12 \mathrm{mM}$ DTT; $0,5 \mu \mathrm{Ci} / \mu \mathrm{l}$ [ $^{35} \mathrm{~S} \mid \mathrm{dATP} \alpha \mathrm{S} ; 0,25 \mathrm{U} / \mu l$ fragmento Klenow da E.coli DNA polimerase I.

-"T mix" - 6,25 $\mu \mathrm{M}$ dTTP; $125 \mu \mathrm{M}$ dCTP; $125 \mu \mathrm{M}$ dGTP; $250 \mu \mathrm{M}$ ddTTP; 25 mM Tris$\mathrm{HCl} \mathrm{pH} 7,5$.

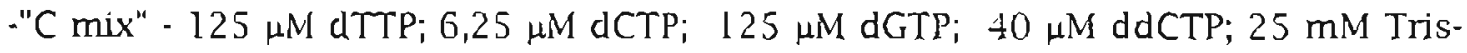
$\mathrm{HCl} \mathrm{pH} 7,5$.

-"G mix" - $125 \mu \mathrm{M}$ dTTP; $125 \mu \mathrm{M} \mathrm{dCTP;} \mathrm{6,25 \mu M} \mathrm{dGTP;} 80 \mu \mathrm{M}$ ddGTP; 25 mM TrisHCl $\mathrm{pH} 7,5$.

-A mix" - $125 \mu \mathrm{M}$ dTTP; $125 \mu \mathrm{M}$ dCTP; $125 \mu \mathrm{M}$ dGTP; $5 \mu \mathrm{M}$ ddATP; 25 mM Tris$\mathrm{HCl} \mathrm{pH} 7,5$.

-Soluçāo caça de dNTP - dATP, dCTP, dGTP e dTTP 0,25 mM cada.

-Solução de corantes/formamida - $98 \%(v / v)$ formamida deionizada; 0,1\% (p/v) azul de bromofenol; $0,1 \%(\mathrm{p} / \mathrm{v})$ xileno cianol; 10 mM EDTA.

Prepararam-se $8 \mu \mathrm{L}$ de uma soluçāo de oligonucieotidio iniciador para cada clone a ser sequenciado. Esta solução é composta de $2 \mu \mathrm{L}$ \{0,4 picomoles) de iniciador, $1 \mu \mathrm{L}$ de TM e $5 \mu \mathrm{L}$ de água bidestilada. Dispensaram-se aliquoras de $2 \mu \mathrm{L}$ de fíra molde em 4 paços contiguos de uma microplaca de plástico e a cada um destes poços foram adicionados $2 \mu \mathrm{L}$ da soluçāo do iniciador. A mícroplaca foi coberta com um plástico fúno (Magipack ${ }^{\otimes}$ e centrifugada por 30 segundos a $1.000 \mathrm{rpm}$ (centrifuga de mesa Beckman TJ-6 com rotor TH4). Procedeu-se então a uma incubaçāo em estufa a $55^{\circ} \mathrm{C}$ por uma hora.

A microplaca contendo as fitas molde e o iniciador foi rerirada da estufa a $55^{\circ} \mathrm{C}$, centrifugada e esfriada atė atingir a temperanura ambiente. Em cada um dos poços foram adicionados $2 \mu \mathrm{L}$ das soluções de desoxi e didesoxinucleoridios. A seguir adicionaram-se em cada poço $2 \mu \mathrm{L}$ da soluçāo mistura de enzima. A microplaca foi centrifugada por 30 segundos e mantida à temperatura por 15 minutos. A seguir adicionaram-se em cada poço $2 \mu$ de umá solução caça de dNTP. Novamente centrifugou-se a microplaca e incubou-se por mais 15 minutos à temperatura ambiente. A reação foi interrompida com a adição de $2 \mu l$ por poço de solução de corantes/formamida. A microplaca foi centrifugada e incubada sem tampa a $80^{\circ} \mathrm{C}$ por 20 minutos para desnaturar o DNA e reduzir o volume total de cada amostra.

\subsubsection{Seqüenciamento de DNA de fïta dupla}

2.25.3.1. Preparaçăo dos moldes de DNA por desnaturação alcalina 
Para cada reaçāo de seqüenciamento foram uñlizados $3 \mu \mathrm{g}$ de DNA plasmidial obtido por midipreparaçōes (item 2.14.3) ou por preparaçōes em larga escala em gradiente de césio (item 2.14.4). A desnaturação do DNA foi realizada de acordo com o método de Mierendorf \& Pfeffer (1987). O DNA foi diluido em $20 \mu \mathrm{L}$ de água deionizada e adicionado de $2 \mu \mathrm{L}$ de uma solução $2 \mathrm{~N} \mathrm{NaOH} / 2 \mathrm{mM}$ EDTA. As amostras foram incubadas por 5 minutos à temperatura ambiente, adicionadas de $7 \mu \mathrm{L}$ de água, $3 \mu \mathrm{L}$ de acetato de sódio $3 \mathrm{M}$ (pH 5,2) e $75 \mu \mathrm{L}$ de etanol. Após uma incubação de 5 minutos em banho de gelo seco/acetona, procedeu-se a uma centrifugação a $10.000 \mathrm{~g}$ por 5 minutos. Os sedimentos foram lavados com $200 \mu \mathrm{L}$ de etanol $70 \%$ gelado, sêcos sob vácuo e armazenados a $-20^{\circ} \mathrm{C}$ até o uso.

\subsubsection{Reação de seqüenciamento com T7 DNA Polimerase}

Utilizou-se o sistema "T7Sequencing Kit TM" (Pharmacia), seguindo as instruçōes do fabricante. As soluções utilizadas e sua composição estāo listadas abaixo:

-"Annealing buffer" - $1 \mathrm{M}$ Tris-HCl (pH 7,6); $100 \mathrm{mM} \mathrm{MgCl} ; 160 \mathrm{mM} \mathrm{DTT}$.

-"Labelling mix" - 1,375 $\mu \mathrm{M}$ dCTP, dGTP e dTTP (de cada um); 333,5 mM NaCl.

"A short-mix" - $840 \mu \mathrm{N}$ dCTP, dGTP e dTTP (de cada); 93,5 $\mu \mathrm{M}$ dATP; $14 \mu \mathrm{M}$ ddATP; $40 \mathrm{mM}$ Tris- $\mathrm{HCl}(\mathrm{pH} \mathrm{7,6);50} \mathrm{mM} \mathrm{NaCl}$.

-"C short-mix" - $840 \mu \mathrm{M}$ dATP, dGTP e dTTP (de cada); 93,5 $\mu \mathrm{M}$ dCTP; $17 \mu \mathrm{M}$ ddCTP; $40 \mathrm{mM}$ Tris-HCl (pH 7,6); $50 \mathrm{mM} \mathrm{NaCl}$.

-"G short-mix" - $840 \mu \mathrm{M}$ dATP, dCTP e dTTP (de cada); 93,5 $\mu \mathrm{M}$ dGTP; $14 \mu \mathrm{M}$ ddGTP; $40 \mathrm{mM}$ Tris- $\mathrm{HCl}(\mathrm{pH} 7,6) ; 50 \mathrm{mM} \mathrm{NaCl}$.

-"T short-mix" - $840 \mu \mathrm{M}$ dATP, dCTP e dGTP (de cada); 93,5 $\mu \mathrm{M}$ dTTP; $14 \mu \mathrm{M}$ ddTTP; $40 \mathrm{mM}$ Tris- $\mathrm{HCl}(\mathrm{pH} \mathrm{7,6);} 50 \mathrm{mM} \mathrm{NaCl}$.

$\therefore$ "Stop solution" - 0,3\% Azul de Bromofenol; 0,3\% Xileno Cianol FF; 10 mM EDTA (pH 7,5); $97,5 \%(v / v)$ formamida deionizada.

-"T7 dilution buffer" - 20 mM Tris- $\mathrm{HCl}(\mathrm{pH} 7,5) ; 5 \mathrm{mM}$ DTT; $100 \mu \mathrm{g} / \mathrm{mL} \mathrm{BSA;} 5 \%$ glicerol $(v / v)$.

Ao sedimento de DNA desnaturado foram adicionados 5 picomoles de iniciador e 2 $\mu \mathrm{L}$ de "annealing buffer", completando-se o volume com agua para um toral de $1+\mu \mathrm{l}$. A hibridização entre iniciador e molde foi feita através de incubaçōes a $67^{\circ} \mathrm{C}$ por 2 minutos, $37^{\circ} \mathrm{C}$ por 15 minutos e à temperatura ambiente por 10 minutos.

Após o esfriamento foram adicionados a cada amostra $1 \mu \mathrm{L}$ de ${ }^{35} \mathrm{~S} J \mathrm{~d}$ ATP $\alpha \mathrm{S}, 2 \mu \mathrm{L}$ de T7 DNA polimerase (previamente diluida 1:5 em "T7 dilution buffer") e $3 \mu \mathrm{L}$ de "labelling mix". Os componentes da mistura foram homogeneizados e incubados à temperatura 
ambiente por 5 minutos. Paralelamente, 4 tubos Eppendorf ${ }^{\otimes}$ foram marcados com as letras $\mathrm{T}, \mathrm{C}, \mathrm{G}$ e $\mathrm{A}$, adicionados de $2,5 \mu \mathrm{L}$ das soluções de terminação ("short mix") contendo ddTTP, ddCTP, ddGTP e ddATP, e aquecidos a $37^{\circ} \mathrm{C}$ por 1 minuto. A cada um destes rubos foram adicionados $4,5 \mu \mathrm{L}$ da reação de marcação, seguindo-se uma incubação a $37^{\circ} \mathrm{C}$ por 5 minutos. As reaçōes foram interrompidas pela adição de $5 \mu \mathrm{L}$ de "stop solution".

Para as amostras destinadas apenas à identificaçāo de clones deletados, com sobreposição de seqüência, obtidas por dígestão com Exonuclease III (ver item 2.25.1), procedeu-se a uma reação de seqüenciamento com apenas uma base. Nesse caso, $5 \mu \mathrm{L}$ de DNA obtido por "speed-prep" (ver item 2.14.2) foram utilizados na desnaturação alcalina. Foi preparada uma solução-mãe de iniciador, "annealing mix" e água, mantendo-se as mesmas ргорorçōes de cada reagente recomendadas no protocolo original. Para cada tubo contendo o sedimento de DNA foram adicionados $3,5 \mu \mathrm{L}$ da soluçāo (um quarto do volume do protocolo original). A hibridização foi realizada nas condições já descritas acima. A seguir adicionaram-se a cada tubo $1,5 \mu \mathrm{L}$ de uma solução contendo o radioisótopo, "labelling mix" e T7 DNA Polimerase (com as mesmas proporçōes relatadas previamente) e incubou-se à temperatura ambiente por 5 minutos. A reação de terminação foi feita com a adição de $2,5 \mu \mathrm{L}$ da "termination mix" e incubação a $37^{\circ} \mathrm{C}$ por 7 minutos. Nesta etapa foi feita uma alteração major em relação à técnica padrāo. A transferência de $4,5 \mu \mathrm{L}$ da reação de marcação de cada tubo tornaria o mérodo muito lento e complexo para um número grande de amostras. Optou-se em aplicar o volume de "termination mix" diretamente no tubo contendo a reação de marcaçāo e, para compensar o fato de ele não estar previamente aquecido a $37^{\circ} \mathrm{C}$, aumentou-se o tempo de íncubação para 7 minutos. Após incubação, adicionaram-se a cada tubo $5 \mu \mathrm{L}$ de "stop solution".

\subsubsection{Reação alternativa de extensāo com Terminal desoxinucleotidil Transferase (TdT)}

O seqüenciamento de DNA de fita dupla está mais sujeito à ocorrência de artefatos do que o de fita simples. Regiōes de estrutura secundária podem causar paradas prematuras da polimerização da cadeia de DNA em pontos especificos. Nesse locais as bandas normais são obscurecidas por bandas radioativas de igual intensidade nos quatro canais e na mesma posição. Para reduzir a ocorrência desse tipo de artefato foi empregado o protocolo descrito por Fawcett \& Bartlett (1990). Às amostras presentes nos tubos, após a reação de terminação, adicionou-se $1 \mu \mathrm{L}$ de uma solução de TdT contendo $1 \mathrm{~mA}$ dNTP e 1,j U de TdT em tampão $40 \mathrm{mM}$ Tris- $\mathrm{HCl}$ pH 7,5/20 mM $\mathrm{MgCl}_{2} / 50 \mathrm{mM} \mathrm{NaCl}$. Os tubos foram incubados por 30 minutos a $37^{\circ} \mathrm{C}$ e adicionados de $S \mu \mathrm{L}$ de "stop solution". A função da enzima TdT é de estender randomicamente as fitas de DNA que tenham sofrido uma parada prematura, de forma a espalhar o sinal na parte superior do gel e permitir a leitura. 


\subsubsection{Gel de seqüenciamento}

2.25.4.1. Gel de seqüenciamento com gradiente de força iônica

Unilizaram-se as seguintes soluções para a preparação do gel de seqüenciamento:

-Solução estoque 40\% Acrilamida - 38,0\% (p/v) acrilamida e 2,0\% (p/v) de bisacrilamida. A solução foi deionizada por 15 minutos com a resina Biorad RG 501-X8 $15 \mathrm{~g}$ de resína para $250 \mathrm{~mL}$ de solução), filtrada e armazenada a $4^{\circ} \mathrm{C}$ em frasco escuro.

$-0,5 \times$ TBE gel mix - 7,5\% acrilamida (do estoque 40\%); 7,66 M uréia; 0,5 x TBE, estocada a $4^{\circ} \mathrm{C}$ em frasco escuro.

$-5.0 \times$ TBE gel mix - 7,5\% acrilamida (do estoque 40\%); 7,66 M uréia; 5 x TBE; 0,005\% azul de bromofenol, estocada a $4^{\circ} \mathrm{C}$ em frasco escuro.

Foi utilizada uma cuba de seqüuenciamento de DNA Sequi-Gen ${ }^{\otimes}$ da Bio-Rad. Para a montagem do gel as płacas de vidro foram meticulosamente limpas com água e detergente, e em seguida com etanol. A placa interna foi siliconizada com dimetildiclorosilano (solução $2 \% \mathrm{v} / \mathrm{v}$ em hexano). A montagem foi feita utilizando espaçadores de teflon com $0,3 \mathrm{~mm}$ de espessura. As placas foram seladas com $15 \mathrm{~mL}$ de gel de seqüenciamento $6 \%$ contendo $0,125 \%(\mathrm{p} / \mathrm{v})$ de persulfato de amônio e $0,5 \%$ de TEMED. O gel de comida, baseado no mérodo de Biggin et al. (1983), foi feiro em gradiente de $0,5 \mathrm{x}$ a $5 \mathrm{x}$ TBE. Recolheram-se $6 \mathrm{~mL}$ da solução $0,5 \times$ TBE gel mix contendo $0,05 \%$ de persulfaro de amônio e $0,2 \%$ de TEMED cm uma pipeta de $10 \mathrm{~mL}$. Na mesma pipeta foram recolhidos $7 \mathrm{~mL}$ da soluçăo $5,0 \times \mathrm{TBE}$ gel mix contendo persulfato e TEMEED. O gradiente foi formado pela aspiraçāo lenta de três bolhas de ar pela pipeta. A solução foi vagarosamente aplicada entre as placas de vidro e o volume total do gel foi completado com a soluçāo 0,5 x TBE gel mix. Deixou-se então o gel polimerizar por pelo menos 30 minutos. A corrida eletroforética foi realizada sob potência constante a $37 \mathrm{~W}$ em tampão l x TBE e prosseguiu um pouco além da saída do azul de bromofenol pelo fundo do gel (totalizando cerca de 2,5 horas). Após a eletroforese, a placa siliconizada foi removida e o gel, ainda aderido à outra placa, foi fixado por 30 minutos em soluçāo $10 \%$ de ácido acético e $10 \%$ metanol. A seguir o gel foi transferido para uma folha de papel Whatman $3 \mathrm{MM}$, recoberto com plástico fino (Magipack ) e secado sob vácuo a $80^{\circ} \mathrm{C}$ por 20 minutos. A auto-radiografia foi obtida mediante exposição de uma chapa de raio $X$ ao gel durante a noite à temperatura ambiente. 


\subsubsection{Gel de seqüenciamento com gradiente de espessura}

O gel foi preparado na cuba de seqüenciamento Sequi-Gen ${ }^{\oplus}$ (BioRad) seguindo-se os mesmos procedimentos de limpeza e selagem das placas descritos no irem anterior. Foram utilizados espaçadores com gradiente de espessura de 0,25 a $0,53 \mathrm{~mm}$ (Bio-Rad). O gel de corrida foi feito com uma concentração de $6 \%$ de acrilamida e $7 \mathrm{M}$ uréia em tampão TBE lx, contendo 0,0375\% de persulfato de amônio e 0,15\% de TEMED. Com o objetivo de aquecer o gel atè a temperatura de $50-55^{\circ} \mathrm{C}$, procedeu-se a uma pré-corrida eletroforetica por 40 minutos a $45 \mathrm{~W}$. As amostras de DNA foram incubadas em banho de água a $85^{\circ} \mathrm{C}$ por 3 minutos, colocadas em gelo, e imediatamente aplicadas no gel. A corrida eletroforérica foi realizada a $40 \mathrm{~W}$ por cerca de 2 horas em rampão TBE lx. Para a resoluçāo de fragmentos maiores foi utilizado um gel com apenas $5 \%$ de acrilamida e um rempo de corrida de 4 a 5 horas de duraçāo. Após a eletroforese, o gel, aderido a uma das placas, foi fixado por 30 minutos em solução contendo $10 \%$ de ácido acérico e $10 \%$ de etanol. A seguir o gel foi

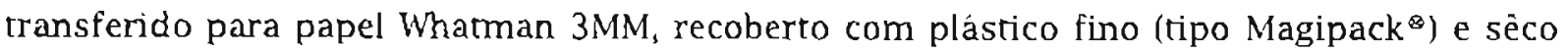
sob vácuo a $80^{\circ} \mathrm{C}$ por 30 minutos. A auto-radiografla foi obtida mediante exposição de um filme radiográfico ao gel durante 24 a 48 horas à temperatura ambiente.

2.26. Análise computacional dos dados das seqüências nucleotídicas

\subsubsection{Programa DNASIS}

O pacote de programas DNASIS 6.0 (Hitachi Software Engineering Co., Ltd.) foi utilizado para a entrada de dados das sequiências nucleotidicas. Além disso, esse pacote foi empregado para a tradução de seqüências e determinação dos possíveis passos de leitura (ORFs) e sítios de restriçāo.

\subsubsection{Busca de homologia em bancos de dados}

\subsubsection{WinBlast}

As seqüencias de DNA e proteinas foram convertidas para o formato FASTA (Pearson \& Lipman, 1988). A requisiçāo de busca foi preparada através do programa WinBlast (autoria de A. V. Sivaprasad) que foi obtido por FTP anônimo no endereço ftp.emblheidelberg.de. Winßlast é um programa que auxilia a elaboração de requisições de busca $\mathrm{e}$ recuperação de sequências via o servidor BLAST do NCBI por correio eletrônico. Para seqüências protéicas foram utilizadas as matrizes de substituiçăo PAM250 e BLOSUM62. 


\subsubsection{BLAST}

A requisiçăo de busca de homologia, preparada pelo programa WinBlast, foi enviada por correio eletrônico para o computador servidor do NCBI (National Center for Biotechnolgy Information) no endereço blast@ncbi.nlm.nih.gov. Esse servidor processa a informação utilizando o programa BLAST (Altschul et al., 1990) cujo algorimo busca alinhamentos que otimizam a medição de similaridades locais. O programa BLAST (Basic Local Alignment Search Tool) pode ser utilizado com o parâmetro N, para a comparação de uma seqüência nucleotídica contra um banco de dados de seqüências nucleotidicas. Caso se queira a comparação de seqüências protéicas utiliza-se o parâmetro P. Finalmente, se o objetivo for a comparação de uma seqüência nucleotidica contra um banco de sequiências proteicas, pode-se usar o parâmetro $X$. Nesse caso, a seqüência nucleotídica é traduzida nos seis passos de leitura possiveis (considerando-se as duas orientaçōes). Cada uma das seqüências protéicas geradas é entāo comparada às seqüências de proteinas.

\subsubsection{Recuperação de seqüências}

\subsubsection{Network Entrez}

O programa cliente Network Entrez foi obtido por FTP anônimo no endereço ncbi.nlm.nih.gov. Este programa funciona no ambiente operacional Windows e necessita da plataforma de TCP/IP Winsock 1.l. Para fornecer essa plataforma foi utilizado o programa Trumpet Winsock 1.0 (autoria de Peter Tattam), que por sua vez foi obtido por FTP anônimo no endereço petros.psychol.utas.edu.au. Através do programa cliente do Entrez foí possivel acessar em tempo real o computador servidor nos Estados Unidos. Utilizando os respecrivos números de acesso dos genes, foi possivel reccber os dados completos das seqüências nucleotídicas e protéicas, bem como os respecrivos sumários do banco de dados Medline.

\subsubsection{Serviço de recuperação de seqüencias por correio eletrônico}

Uma alternativa à recuperaçāo das seqüências em tempo real por meio do Nentrez foi a urilizaçāo do serviço de formecimento de seqüências do NCBI por correio eletrônico. Utilizando o programa WinBlast, descrito no item 2.26.2.1, foram elaboradas requisiçoes de recuperação de seqüências nucleotídicas e protéicas. As requisiçōes foram enviadas por correio eletrônico para o computador servidor do NCBI no endereço retrieve@ncbi.nim.nih.gov. 
2.26.4. Programas de alinhamento de seqüências para computadores IBM-PC

\subsubsection{MACAW}

$O$ alinhamento de seqüências nucleotidicas e protéicas foi feito com o programa MACAW (Multiple Alignment Constuction an Analysis Workbench), desenvolvido por Schuler et al. (1991). Esse programa foi obtido por FTP anônimo no cndereço ncbi.nlm.nih.gov e utiliza um algoritmo semelhante ao do programa BLAST. O programa MACAW roda sob o ambiente operacional Windows e permite a elaboraçāo de múltiplos alinhamentos e sua apresentaçāo na forma de seqüencias alinhadas, blocos de alinhamento e esquema de blocos de similaridade.

\subsubsection{Clustal V}

O programa Clustal V (Higgins \& Sharp, 1988; Higgins et al., 1991), obtido por FTP anônimo do servidor ftp.embl-heidelberg.de, também permite o alinhamento de múltiplas seqüências. Sua vantagem $\mathrm{cm}$ relaçào ao MACAW è a maior velocidade e menores requerimentos de memória e equipamento, uma vez que roda sob o DOS. Entretanto, apresenta uma limitaçāo quanto ao tamanho das seqüências a serem alinhadas, que não pode exceder 1.300 pares de bases ou aminoácidos.

\subsubsection{Pacote de análise de seqüências GCG}

Para a análise das caracteristicas estruturais das seqüências nucleotidicas e protéicas foi utilizado o pacote de análise de seqüências GCG (Genetics Computer Group Inc.), desenvolvido originalmente na Universidade de Wisconsin (Devereux et al. 1984). Esse conjunto de programas roda em estações de trabalho VAX sob sistema operacional VMS ou em plataformas com sistema UNIX. Nesse trabalho utilizou-se um computador VAX da FIOCRUZ (Rio de Janeiro) e um IRIS (Silicon Graphics) do BBRC (Brazilian Bioinformatics Resource Center) em Brasília. Esses computadores foram acessados via Internet por "login" remoto nos endereços dcc00l.cict.fiocruz.br e asparagin.cenargen.embrapa.br, respectivamente. A seguir serão apresentados brevemente os programas do pacote GCG utilizados nesse trabalho, como descritos no manual original do programa:

-CODONPREFERENCE - Programa que tenta reconhecer seqüências codificadoras de proteínas medindo a similaridade de seu uso de códons com uma tabela de freqüência de uso de códons. Também considera a tendência ("bias") de sua composição (geralmente GC) na terceira posição de cada códon. 
-BESTFIT - Faz um alinhamento do melhor segmento de similaridade entre duas seqüências. Alinhamentos ótimos são obtidos mediante a inserção de lacunas para maximizar o nümero de identidades.

-COMPARE - Compara duas seqüências de DNA ou proteinas e cria um arquivo de pontos de similaridade entre elas.

-DOTPLOT - Produz um gráfico tipo "dot-plot" a partir do arquivo gerado pelo programa COMPARE.

-FRAMES - Mostra as ORFs nos seis passos de leítura de uma seqüência de DNA.

-GAP - Faz um alinhamento de duas seqüências completas maximizando o número de identidades e minimizando o número de lacunas.

-MOTIFS - Procura motivos de seqüências a partir de padrões definidos no banco de dados PROSITE .

-PEPTIDESTRUCTURE - Faz prediçōes de esmutura secundária para uma seqüência protéica, incluindo mediçōes de antigenicidade, flexibilidade, hiơrofobicidade e probabilidade de localizaçāo na superfície.

-PLOTSTRUCTURE - Produz um gráfico a partir do arquivo de mediçoes criados pelo programa PEPTIDESTRUCTURE.

-REFORMAT - Permite a importação de arquivos de seqüências e sua conversão no padrão GCG.

-REPEAT-Ajuda a encontrar repetiçōes diretas em seqüências.

-TESTCODE - Programa que ajuda a identificar seqüências codificadoras plotando uma medição da não randomicidade de composição a cada terceira base.

\subsection{Eletroforese de campo pulsado}

A eletroforese de campo pulsado de cromossomos de formas epimastigotas de $T$. cruzi, foi gentilmente realizada por Maria Isabel Cano (laboratório do Dr. José Franco da Silveira - Escola Paulista de Medicina) em um gel de agarose 1,2\% no aparelho Gene Navigator System da Pharmacia, que utiliza um sistema de eletródos dispostos em um contorno hexagonal (Chu et al. 1986). As condiçōes de corrida e outros aspectos do protocolo serão publicados brevemente pelos autores. Após a corrida o gel foi corado com brometo de etídio e fotografado. Os cromossomos foram transferidos para uma matriz de nylon segundo o método de Southern (1975), conforme descrito no item 2.23.1. As membranas, gentilmente cedidas por M. I. Cano, foram hibridizadas com sondas radioativas nas mesmas condiçōes apresentadas no item 2.24.2. 


\section{RESULTADOS}

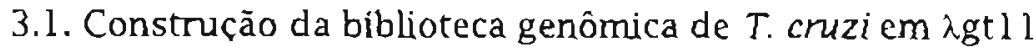

Com o objetivo de isolar genes codificadores de antígenos de $T$. cruzi, procedeu-se à construção de uma biblioteca genômica no vetor de expressāo igrll l. A razão de se preferir utilizar o DNA genômico, ao invés do cDNA, residiu na evidência de que, ao contrário de outros eucariotos, não foi relatada até o momento a existência de introns nos genes de tripanossomatídios. Além disso, a construção de bibliotecas genômicas é mais fácil e rápida.

Para a construçāo da biblioteca, o DNA do parasita foi fragmentado mecanicamente por múltiplas passagens através de uma agulha, conforme descrito no item 2.9.1. Após 1.000 passagens, o DNA apresentou uma população de fragmentos de 2,1 a $5,4 \mathrm{~kb}$, com predominância na faixa de $3,4 \mathrm{~kb}$. Os fragmentos obtidos tiveram suas extremidades reparadas e foram ligados a adaptadores de EcoRI de três tamanhos diferentes (item 2.9.1). Os fragmentos foram então ligados com o DNA do vetor de expressão $\lambda$ gtl 1 (item 2.9.6) e o produto encapsidado in vitro (item 2.9.7).

A biblioteca resultante foi plaqueada (ver item 2.9.8) na presença do substrato cromogênico $X$-gad e do indutor IPTG. Urilizou-se como hospedeira a cepa Ir1090 que apresenta defíciências no sisrema de restriçāo ( $h s d R^{-}$), bem como na protease lon. Dessa forma, essa cepa pode ser utilizada tanto para a amplificaçāo da biblioteca, como para a expressão dos genes clonados. As placas de lise nāo recombinantes apresentam coloraçāo azul devido à ação enzimática da $\beta$-galactosidase sobre o substrato gerando um produto colorido. As recombinantes são brancas, pois com a inserção do fragmento de DNA exógeno na extremidade $3^{\prime}$ do gene codificador da $\beta$-gal ocorre a produção de uma enzima inativa.

Através da contagem das placas de lise da biblioteca obteve-se como resultado um total de $76 \%$ de recombinaçăo. O título da biblioteca foi de $2,1 \times 10^{6}$ recombinantes. A representatividade da biblioteca pode ser calculada a partir da equação abaixo:

$N=6 \times \frac{\ln (1-p)}{\ln (1-f)}$ onde:

$\mathrm{N}$ = número de recombinantes necessários a clonagem de um determinado evento.

$\mathrm{p}=$ probabilidade.

$\mathrm{f}=$ razão entre o tamanho médio da população de fragmentos sobre o tamanho do genoma.

Assumindo-se uma probabilidade de $99 \%(\mathrm{p}=0,99)$ de qualquer sequiência estar representada, bem como a orientação do inserto e o passo de leitura estarem corretos: um tamanho médio da população de fragmentos de $3,4 \mathrm{~kb}$; e urna complexidade genômica de $2,5 \times 10^{8} \mathrm{pb}$ para $T$. cruzi (Lanar et al., 1981), obtém-se um número total de clones 
recombinantes de $2,0 \times 10^{6}$. O tótulo da biblioreca superou, portanto, o valor teórico esperado para a clonagem de dererminado evento, com $99 \%$ de probabilidade.

\subsection{Absorção do soro policlonal anti-tct}

Visando a varredura da biblioseca, obteve-se urn soro policional anti-tct em coelho, conforme a técnica descrita no item 2.7.1. Para a remoção dos anticorpos inespecíficos contra antígenos bacterianos, procedeu-se à absorção do soro (ver item 2.10.1). Após 4 ciclos de absorçāo o soro ainda apresentou uma pequena reatividade contra placas de lise não recombinantes. Optou-se em não eliminar totalmente essa reatividade, pois ela permite distinguir perfeitamente as placas de lise negativas das positivas. Além disso, a visualização das placas negativas ajuda a identificar mais facilmente o posicionamento das placas positivas e distinguí-las de sinais devidos a artefatos.

\subsection{Isolamento dos clones recombinantes $\mathrm{Bl} 2$ e $\mathrm{Bl} 3$}

A biblioteca genómica de $T$. cruzi foi plaqueada e os clones foram selecionadas utilizando o soro anti-tcr absorvido, conforme relatado no item 2.10.2. O plaqueamento de 34.000 recombinantes levou à identificaçăo de 7 sinais positivos. Após três etapas subseqüentes de plaqueamento, destinadas à purificação dos clones, os sinais positivos foram confirmados para apenas dois clones. Esse clones foram denominados B12 e B13 em referência ao número das placas de origem. O DNA dos fagos recombinantes foi obtido por minipreparaçōes (ver item 2.13.1) e digerido com EcoRI. Após eletroforese em gel de agarose (dados não mostrados), foi possivel determinar o tamanho dos insertos. $O$ clone B12 apresentou um inserto de 350 pb enquanto B13, um fragmento de 600 pb.

\subsection{Subclonagem dos insertos B 12 e B13 para os vetores $M 13 \mathrm{mp} 18$ e pUCl 8}

Com a finalidade de subclonar os insertos dos clones Bl2 e Bl3, procedeu-se a minipreparaçōes de DNA (item 2.13.1). O DNA foi digerido com EcoRI e submetido a uma eletroforese em um gel de agarose LMP. As bandas correspondentes aos respectivos insertos foram recolhidas e o DNA purificado como descrito no item 2.15.3. Os insertos foram ligados ao sitio de EcoRI dos vetores $M 13 \mathrm{mpl} 8 \mathrm{e}$ pUCl8. O DNA foi transfectado na bactéria hospedeira JM10l (ver item 2.15.5) e os clones recombinantes foram identificados como descrito no item 2.15.6.. A subclonagem dos insertos dos clones B12 e B13 em pUC 18 visou atender à produção de sondas. Esses insertos são relativamente pequenos quando comparados ao DNA de $\lambda g$ gll. Como conseqüência, a digestão de uma dada massa desse DNA recombinante com EcoRI acaba rendendo uma pequena quantidade de DNA de inserto. 
Utilizando o vetor pUC18, cujo tamanho é de $2,7 \mathrm{~kb}$, acaba-se obtendo uma massa relativamente maior de inserto liberado por massa de DNA digerido. A subclonagem de B12 e B13 no vetor Ml3mpl8 visou a determinaçāo da seqüência nucleotídica desses fragmentos.

\subsection{Seqüenciamento dos clones B 12 e B 13}

As placas brancas de M13 recombinante foram unilizadas para a produçāo de fitasmolde destinadas à reação de seqüenciamento (ver item 2.25.2.1). O sequienciamento dos moldes de DNA de fíta simples foi feito pelo método de terminaçāo de cadeía (Sanger, 1977), conforme descrito no item 2.25.2.2. Foram obtidos subclones em cada uma das orientaçōes dos insertos. A seqüência toral do clone $B 12$ revelou um inserto de $350 \mathrm{pb}$, contendo aproximadamente 6 repetiçōes seriadas de $60 \mathrm{pb}$ ao longo de toda a seqüencia. As repetições são bem conservadas, mas contém algumas variações, como pode ser visto na Figura 1. A sequêência do clone Bl2 é inédita na literatura. O clone Bl3 foi seqüenciado parcialmente, nas extremidades $S^{\prime}$ e $3^{\prime}$ do inserto. Esse clone também apresenta um padrão de sequências repetidas em série (aproximadamente 17), contendo $36 \mathrm{pb}$. A sequiência do clone B13 é homóloga à do clone \#2 descrito por lbañez et al. $(1987,1988)$ e do clone TCR39 isolado por Hoft et al. (1989).

\subsection{Análise do arranjo genômico dos clones B12 e B13}

O arranjo genômico dos insertos clonados foi determinado por Southern blot com DNA de epimastigotas (cepa $\lambda^{\prime}$ ) digerido com BamHI, EcoRI, HindIII, Ncol e Sall. As sondas Bl2 e Bl3 foram sintetizadas a partir dos clones de Ml3 recombinantes, utilizando a técnica de "primer extension" (ver item 2.12.2). Conforme pode ser visto na Figura 2, a sonda Bl2 hibridizou com bandas únicas em todas as digestōes, com exceçāo de Sall, onde houve hibridização com uma dupla de bandas na região de 9,4 kb e uma banda de 1,85 kb. A sonda BI3 hibridizou com uma banda única na digestão com BamHI e com duas bandas nas demais digestões. Esse resultado parece indicar que ambos os genes devem ter apenas uma cópia por genoma haplóide ou então formar um aglomerado de cópias homogêneas e seriadas. Um faro interessante é que ambas as sondas hibridizam com a dupla de bandas de 9,4 kDa. Como scrá visto adiante (ver itcm 3.13), isso é uma conseqüencia da proximidade física dos dois genes. 


\section{B12}

CCA CCC CCC GAG TCT CCT CTC AAG ACC GTG TTT GGA GCA CCG TCT TCG ACT GCT GCA AAG

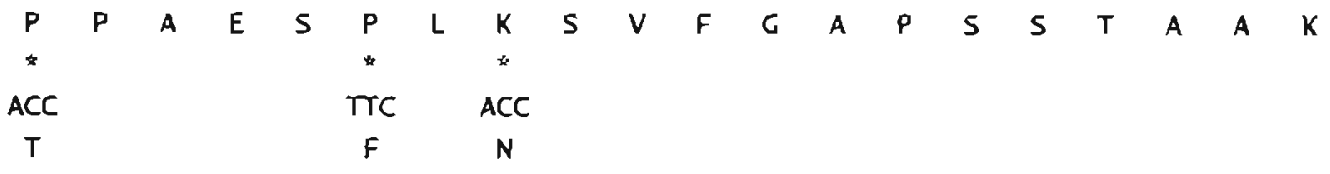

\section{B13}

\begin{tabular}{|c|c|c|c|c|c|c|c|c|c|c|c|}
\hline $\mathrm{CCA}$ & $\mathrm{CCA}$ & $\pi$ & $C G A$ & CAG & $c \subset C$ & $C C A$ & $C C A$ & GGT & GAC & AAA & $C C A$ \\
\hline$P$ & $p$ & $F$ & $G$ & $Q$ & A & A & A & G & D & K & $\mathbf{P}$ \\
\hline$\Rightarrow$ & $\Rightarrow$ & & & & & & 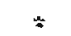 & $\approx$ & & & 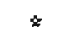 \\
\hline TCA & $\subset \mathrm{A}$ & & & & & & GAA & $C \subset T$ & & & $\widetilde{C A}$ \\
\hline 5 & L & & & & & & $E$ & A & & & $\mathrm{L}$ \\
\hline
\end{tabular}

Figura 1 - Sequiências nucleotídicas das repetições seriadas dos clones Bl2 e Bl3. As seqüências protéicas deduzidas e as posiçōes variáveis estão apresentadas. 


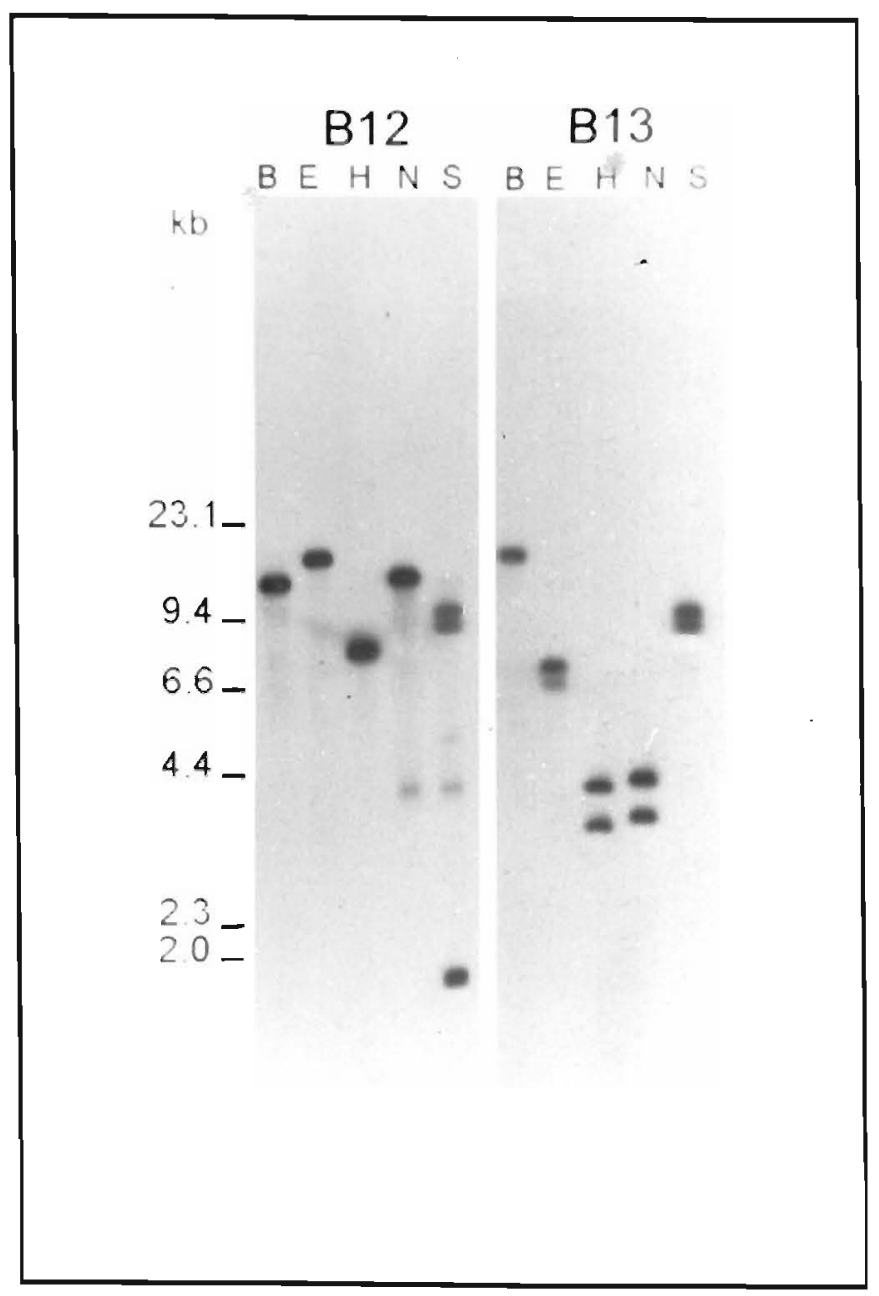

Figura 2 - Southern blot de DNA de formas epimastigotas de T. cruzi (cepa Y) digerido com diferentes enzimas de restrição e hibridizado com sondas dos clones B12 e B13. Gel de agarose 0,7\%. Enzimas: (B) BamHI; (E) EcoRI; (H) HindIII; (N) Ncol; (S) Sall. Marcadores de peso molecular, em quilobases, estão indicados. 
Com o objetivo de verificar se há uma variação do arranjo genómico entre diferentes cepas e estágios evolutivos do parasita, procedeu-se a um ensaio de Southem blot contendo DNA das cepas Y e CL e do clone CL14, isolado de formas epimastigotas e tripomastigotas e digerido com HindIIl. O resultado está apresentado na Figura 3, onde podemos verificar que há uma variação entre as cepas $Y$ e $C L$, mas não entre as formas epimastigotas e tripomastigotas de uma mesma cepa. A sonda Bl2 (Figura 3 A) hibridizou com uma banda única em epimastigotas (canal a) e tripomastigotas (canal d) da cepa Y. Ao contrário, em epimastigotas da cepa CL (canal b) e do clone CL14 derivado da cepa CL (canal c), e tripomastigotas da cepa CL (canal e), houve hibridização com duas bandas. Para o clone B 13 (Figura 3B) também foram evidenciadas diferenças no arranjo genômico entre cepas (comparar canais $a$ e $b$ ou $d$ e e), porém apenas quanto ao tamanho dos fragmentos que hibridizam com a sonda. Novamente não se verificou nenhuma variação entre as formas epimastigotas e tripomastigotas (comparar canais a e $d$ ou $b$ e $e$ ).

\subsection{Identificação dos transcritos correspondentes a B12 e B13}

Com o objetivo de se identificar as espécies de mRNA correspondentes aos insertos Bl2 e Bl3 procedeu-se à purifícaçāo de RNA total de formas cpimastigotas e tripomastigotas pelo método do fenol quente, como relatado no item 2.8 .3 . O rendimento médio obtido nesse método foi da ordem de $20 \mu \mathrm{g}$ de RNA total por $10^{8}$ epimastigotas e cerca da metade para mipomastigotas. O RNA total foi submetido a uma eletroforese em gel desnaturante de agarose/formaldeido, como descrito no item 2.24.1. Como controle, utilizou-se uma amostra desse RNA previamente tratada com $50 \mathrm{mM} \mathrm{NaOH}$ por uma hora a $67^{\circ} \mathrm{C}$. O RNA foi então transferido para nitrocelulose e hibridizado com sondas marcadas dos clones B 12 e B13. Conforme podemos ver na Figura 4, a sonda B 2 hibridizou com uma banda larga de cerca de 7,2 a $8.8 \mathrm{~kb}$ em RNA de epi e tripomasrigotas. Como será visto adiante (Figura 15) essa banda é composta por duas espécies co-migrantes, não resolvidas na concentração de agarose utilizada nesse gel $(1,2 \%)$. Bl3 hibridizou com bandas de 3,5 e $4,2 \mathrm{~kb}$ em ambas as formas evolutivas. O controle tratado com $\mathrm{NaOH}$ não apresentou nenhum sinà, indicando que a hibridização não se devia à presença de DNA contaminante.

\subsection{Expressão dos clones Bl2 e Bl3}

3.8.1. Expressão das protcínas de fusão em bactérias lisogênicas Y1089

Os fagos recombinantes de $\lambda$ gt 11 foram utilizados para lisogenizar a bactéria hospedeira Y1089, que apresenta uma mutaçāo que favorece uma alta freqüência de 


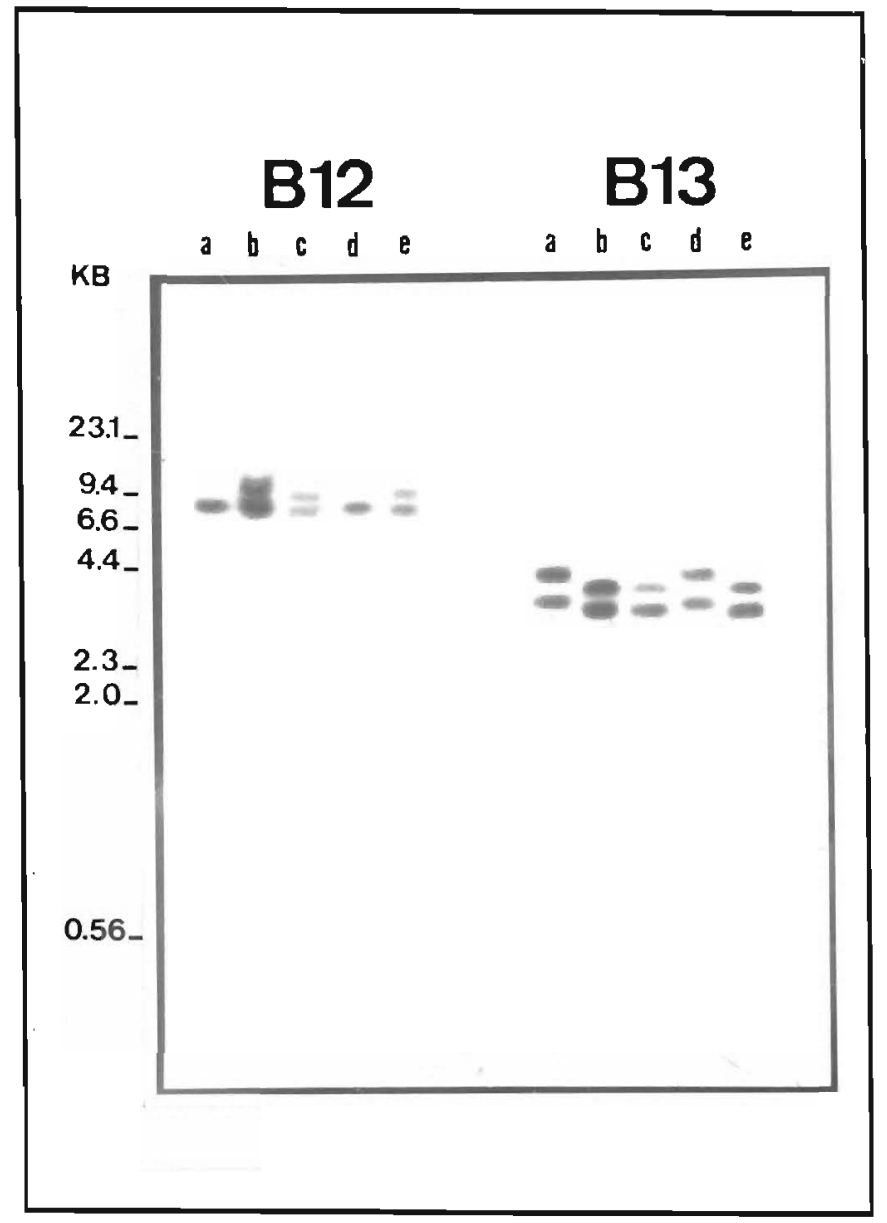

Figura 3 - Southern blot de DNA de T. cruzi digerido com HindIII e hibridizado com sondas dos clones B12 e B13. Amostras: (a) epimastigotas da cepa Y; (b) epimastigotas da cepa CL; (c) epimastigotas do clone $\mathrm{CL14}$; (d) tripomastigotas da cepa $\mathrm{Y}$; (e) tripomastigotas metacíclicos do clone CL 14. Marcadores de peso molecular, em quilobases, estão indicados. 


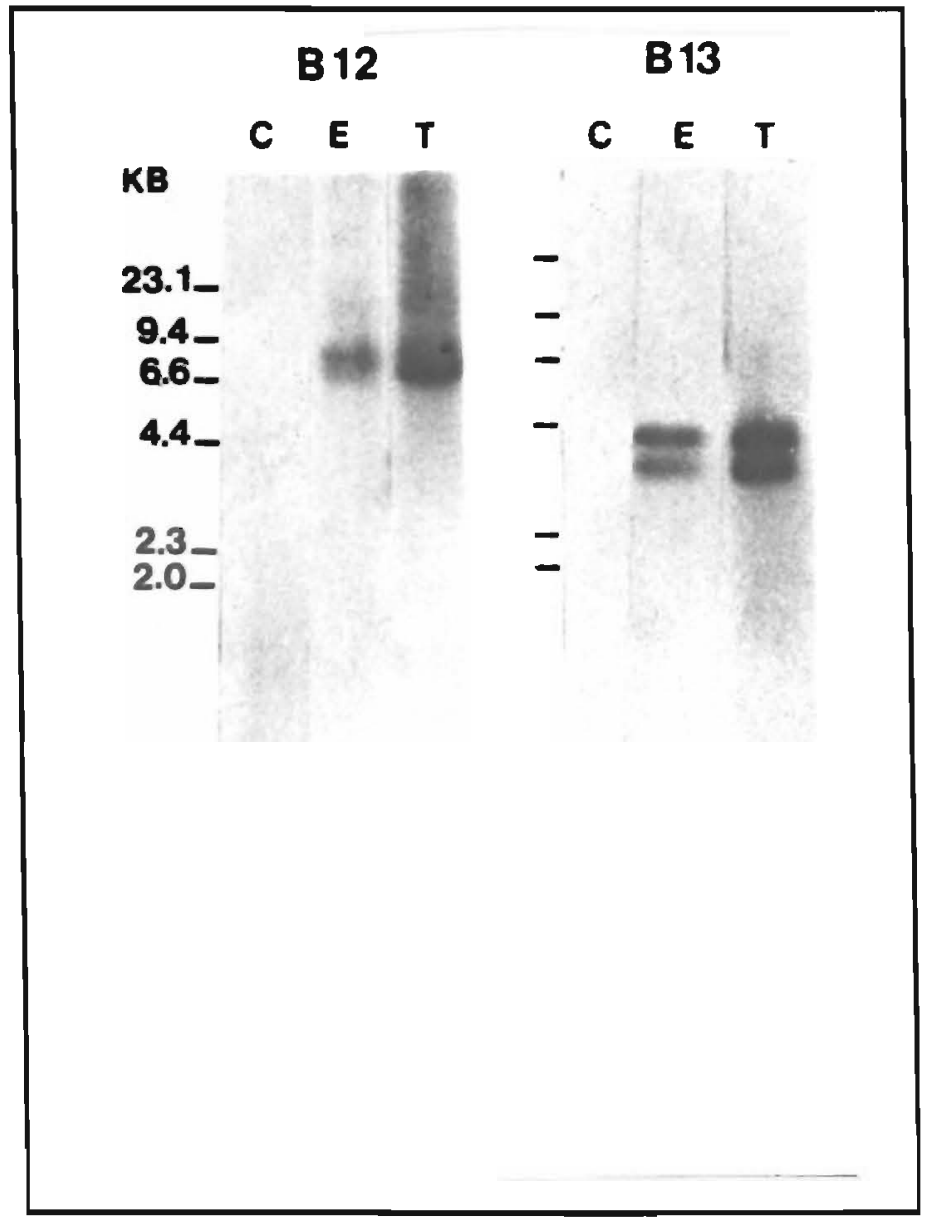

Figura 4 - Northern blot de RNA total de $T$. cruzi hibridizado com as sondas dos clones B12 e B13. Amostras: (C) controle de RNA de epimastigotas previamente tratado com $50 \mathrm{mM}$ $\mathrm{NaOH}$; (E) RNA de epimastigotas; (T) RNA de tripomastigotas. Marcadores de peso molecular de DNA de $\lambda$ cI857 digerido com HindIII, em quilobases, estão indicados. 
lisogenização (hflA150). A lisogenização foi eferuada conforme o item 2.16.1.1. A maior eficiência de lisogenização foi obtida com uma multiplicidade de infecção de 500 . As bactérias lisogênicas dos clones BI2 e Bl3 foram induzidas por diferentes periodos de incubação a fim de otimizar a produçāo da proteína de fusão (ver item 2.16.1.2). Como controle da induçāo foi utilizada uma bactéria lisogênica de $\lambda$ gtll nāo recombinante. Mesmo após várias tentativas, nāo se observou nenhuma banda correspondente à proteína de fusão, em gẻis de poliacrilamida com SDS corados com azul de Coomassie ou com nitrato de prata. A baccéria lisogênica do $\lambda$ gtll l nāo recombinante apresentou uma boa expressão de $\beta$-galactosidase, atestando que as condições do experimento foram adequadas. É possível que a expressão das proteinas de fusão fosse extremamente baixa ou então houvesse um alto grau de degradação. Foi tentado o uso de um tampão de amostra de proteína contendo $3 \mathrm{mM}$ de inibidores de proteases (PMSF e TLCK), assim como a utilização de aquecimento a $55^{\circ} \mathrm{C}$ ao invés de fervura por 3 minutos. Em nenhum caso houve expressão visível das proteínas de fusão nos géis de poliacrilamida. Em vista desses resultados, tentou-se fazer um Western blot dos lisados das bactérias induzidas, utilizando o soro anti-tripomastigota que serviu para a varredura da biblioteca, e que foi previamente absorvido contra antígenos de $E$. coli. Esse teste, por ser muito mais sensivel do que qualquer coloração de proteína em gel, poderia indicar se houve ao menos uma pequena expressão das proteinas de fusāo. De fato foi possivel verificar que o soro reconheceu uma proteina de $132 \mathrm{kDa}$ para o clone Bl2 e de $140 \mathrm{kDa}$ para o clone B13. Não houve qualquer reação do soro frente a um lisado de uma bactéria lisogênica de $\lambda$ gtll não recombinante (dados não mostrados). Os pesos moleculares das proteínas de fusão sāo compativeis com o tamanho dos respectivos insertos clonados.

\subsubsection{Expressão e purificação das proteínas de fusão em DH5 $\alpha /$ pMSge l l}

\subsubsection{Subclonagem de B12 e B 13 no vetor pMSgt 11}

Em função da baixa expressão das proteínas de fusão no vetor $\lambda . g t l l$, decidiu-se subclonar os insertos B1 2 e B13 no vetor pMSgt l l, gentilmente cedido pelo Dr. Artur Scherf (Institute Pasteur, Paris). Esse vetor tem 5350 pb e apresenta os genes de resistência à ampicilina e o lacZ. Na extremidade $3^{\prime}$ terminal do gene lacZ existe uma região de múltiplos sítios de restrição. A tradução de um inserto clonado no sítio de EcoRl obedece ao mesmo passo de leitura existente no vetor $\lambda$ gtll. No sistema DH5 $/ \mathrm{pMSgtl} 1$ não existe o gene lacla, cujo produto é a proteína repressora que se liga ao sítio operador do operon-lac. Conseqüentemente, a síntese de $\beta$-galactosidase é constitutiva nessa bactéria. Outra caracteristica desse sistema é que a proteína de fusão também é enzimaticamente ativa, impedindo uma distinção entre os clones recombinantes e não recombinantes pela 
coloração das colônias plaqueadas com X-Gal. Além disso, entre a extremidade carboxala terminal da $\beta$-galactosidase e o polipeptidio recombinante existe uma seqüência de 4 aminoácidos que define um sítio de clivagem por Fator Xa. Essa característica permite a separação e obtenção do antígeno clonado em sua forma isolada (Scherf et al., 1990).

O DNA dos clones Bl2 e B13 em $\lambda$ gt11 foi obtido por minipreparações (ver item 2.13.1). Após digestão com EcoRI seguida de elerroforese em agarose LMP, os insertos foram excisados e purificados (ver item 2.15.3). A seguir os fragmentos foram ligados ao DNA do vetor pMSgtll e as amostras foram utilizadas para transformar a hospedeira DH5 $\alpha$. Para a identificação dos clones positivos foi feito um imunoensaio das colônias bacterianas, conforme descrito no item 2.16.2.2. Foram selecionadas várias colônias isoladas com sinal positivo, as quais foram testadas quanto à expressão do produto recombinante.

\subsubsection{Expressão das proteinas de fusāo Bl2 e B 13}

As células hospedeiras contendo o vetor rccombinante foram cultivadas e lisadas como descrito (itens 2.16.2.3 e 2.16.2.4). As amostras de lisados obtidos em pequena escala foram submetidas a uma separação eletroforética em gel de poliacrilamida com SDS. O gel foi corado e os resultados demonstraram uma alta expressão das proteínas de fusão dos clones B12 e B 13. Estimativas indicam uma produção da ordem de 30 a $50 \mathrm{mg}$ de proteina de fusão por litro de cultura. Bandas com peso molecular de $132 \mathrm{kDa}$ (B12) e $140 \mathrm{kDa}$ (B13) foram localizadas, mas uma banda de $116 \mathrm{kDa}$ também apareceu bem corada em ambas as amostras, indicando ser possivelmente um produto de degradação parcial (resultados nāo mostrados).

\subsubsection{Determinação da solubílidade das proteínas de fusāo}

Proteínas eucarióticas recombinantes, quando expressas em E. coli, podem se acumular no citoplasma das bactérias. Freqüentemente, no entanto, essas proteínas formam agregados insolúveis denominados corpúsculos de inclusão. O sistema de expressão empregado, a natureza do polipeprídio recombinante e a taxa de expressāo podem determinar se o produto formará agregados, contudo o mecanismo envolvido na sua geração não é totalmente conhecido. Os corpúsculos de inclusão podem ser observados em microscopia de contraste de fase devido ao scu alto índice de refração. Pelo fato de eles representarem agregados protéicos insolúveis, sua purificação é mais complicada. Foram desenvolvidas técnicas pelas quais esses agregados são sedimentados e a proteína, sob ação de agentes desnaturantes, é gradativamente solubilizada. Finalmente, a proteína semipurificada é renaturada, assumindo sua conformação nativa (Marston, 1986; 1987). 
Com a finalidade de verificar se as proteínas de fusão dos clones Bl2 e B13 em pMISgt 11 podiam ser isoladas na forma de um sedimento insolúvel, procedeu-se à técnica descrita no item 2.16.2.5. O lisado bacteriano foi centrifugado e o sedimento tratado com diferentes concentraçōes de detergente e uréia. As amostras coletadas de cada etapa do experimento foram analisadas por eletroforese em gel de poliacrilamida com SDS. Foi verificado que as proteinas de fusāo dos clones Bl2 e Bl3 permaneceram essencialmente no sobrenadante inicial, indicando que não houve formação de corpúsculos de inclusão. Esses resultados estão de acordo com os obtidos para a maior parte das proteínas clonadas em pMSgt 11 (Scherf et al, 1990). Sabendo-se então que as proteínas de fusão dos clones Bl2 e B13 eram solúveis, partiu-se para a sua purificcação por cromatografia de afinidade.

\subsubsection{Purificaçāo das proteinas de fusão}

As proteínas de fusão de Bl2 e Bl3 foram purificadas a partir do lisado bacteriano em colunas de pAPTG-agarose. O pAPTG, sendo um galactosídio, tem afinidade pela $\beta$ galactosidase. Essa afinidade pode ser diminuída pelo emprego de um tampão com pH alcalino. Com base nessas caracteristicas, procedeu-se a uma cromatografia de afinidade em colunas de pAPTG-agarose, como descrito no item 2.16.2.6. As frações de I mL, eluidas com tampão tetraborato, tiveram sua atividade enzimática determinada, utilizando ONPG como substrato (ver item 2.16.2.7). O produto da hidrólise catalisada pela $\beta$-galactosidase é o o-nitrofenol, que tem coloração amarela. As frações de números 2 a 6 demonstraram reprodutivelmente a maior atividade e foram reunidas e utilizadas para os experimentos posteriores.

As proteinas de fusão purificadas foram submetidas a uma eletroforese em gel de poliacrilamida com SDS. Na Figura $5 \mathrm{~A}$ podem ser vistas as proteinas de fusão dos clones Bl2 (canal a) e Bl3 (canal b). Além das bandas de 132 kDa e 140 kDa existem outras de peso molecular inferior, principalmente de $116 \mathrm{kDa}$, que sāo produtos de degradação parcial. A análise por Western blot (Figura 5B) revelou que as bandas correspondentes às proteinas de fusāo, assim como a banda de $116 \mathrm{kDa}$ e algumas bandas de menor peso molecular são reconhecidas por uma mistura de soros humanos chagásicos. O mesmo ensaio foi feito com o soro de coelho anti-tct, obtendo-se resultados idênticos (dados não mostrados). Uma amostra controle, contendo ß-galactosidase não recombinante, não foi reconhecida pelos soros (dados não mostrados), indicando que tanto a proteína de $116 \mathrm{kDa}$, como as bandas de mais baixo peso molecular sāo produtos de degradação parcial que contém ainda fragmentos do antigeno clonado. 


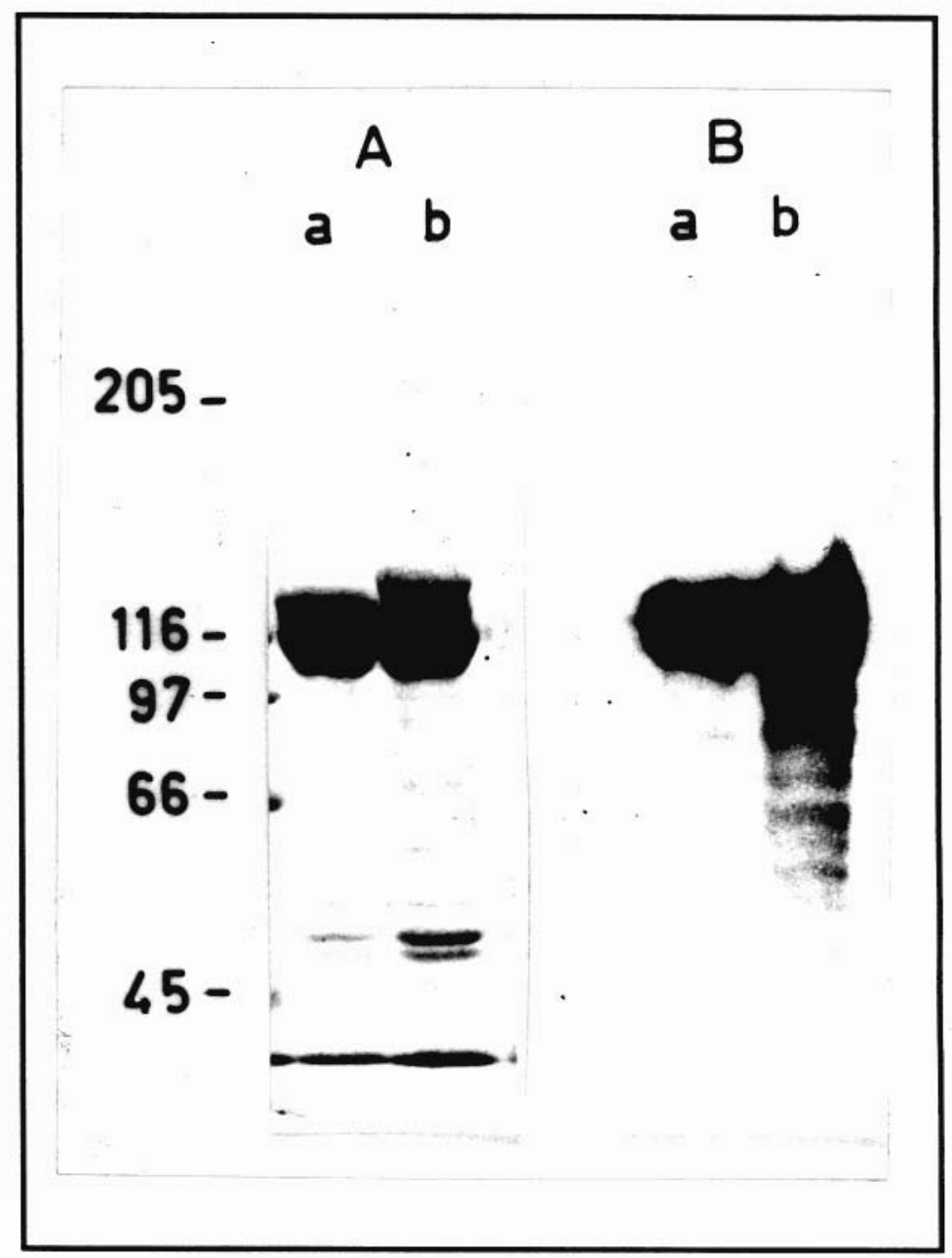

Figura 5 - Proteinas de fusão dos clones B12 (a) e B13 (b), produzidas no sistema DH5 $\alpha /$ pMSgt1 1 e purificadas por afinidade em colunas de pAPTG. (A) Eletroforese em gel de poliacrilamida $8 \%$ corado com azul de Coomassie; (B) Western blot incubado com uma mistura de soros humanos chagásicos pré-absorvida contra antigenos de $E$. coli. Marcadores de peso molecular em quilodaltons são apresentados. 
Foram tentados diferentes tempos de incubação no cultivo da bactéria produtora com o intuito de verificar se esta degradaçāo não poderia ser reduzida. Foi verificado (dados não mostrados) que as proteinas de fusão começam a ser visualizadas em gel após 4 horas de incubação e que sua concentração não aumenta depois de 7 horas. A banda de 116 $\mathrm{kDa}$ aparece simultaneamente à proteína de fusào íntegra. Também foram testadas duas hospedeiras diferentes (RRI $\triangle M 15$ e CAG456), que contém o gene lacla. Contudo, mesmo nesses sistemas indutivos, não foi observada melhora da expressão e nem diminuiçāo da degradação protéica.

\subsection{Caracterização dos antígenos de $T$. cruzi clonados}

3.9.1. Uso de soros policlonais obridos por imunização de coelhos com as proteinas de fusão

As proteínas de fusāo foram utilizadas em imunizaçōes de coelhos. Os animais foram inoculados por via subcutânea ou por múltip̧las inoculaçōes intradérmicas (ver itens 2.7.2.1 a 2.7.2.3). Contudo, a resposta imune obtida foi muito baixa, especialmente para o antigeno 812. Uma vez que os animais inoculados intradermicamente haviam demonstrado o desenvolvimento de certa resposta imune, decidiu-se utilizá-los para uma tentativa final de aumento do título de anticorpos. Os animais foram inoculados por via intravenosa com duas doses de $300 \mu \mathrm{g}$ do antígeno, intercaladas por 2 semanas. Os animais foram sangrados 1 mês após a ültima dose. O nivel de anticorpos, estimado por dot-blot e Western-blot, apresentou um pequeno incremento.

Como o objetivo de identificar os antígenos de T. cruzi, correspondentes a B12 e B13 e reconhecidos por esses soros, procedeu-se a um ensaio de Western blot (ver itens 2.20.1 a 2.20.3). Visando obter uma melhor resolução dos antígenos detectados, realizaram-se os ensaios em duplicata, com géis de $5 \%$ e $8 \%$ de poliacrilamida. O soro anti- $\beta$-gal-Bl 2 reconheceu bandas de $200 \mathrm{kDa}$ em epimastigotas (Figura 6A, tira c) e $230 \mathrm{kDa}$ em tripomastigotas (Figura 6C, tira c). O soro anti- $\beta$-gal-B13 reconheceu duas bandas principais de 135 e 116 kDa em epimastigotas (Figuras 6A, tira $d$ ) e de 140 e 116 kDa em tripomastigotas (Figuras $6 \mathrm{~B}$ e $6 \mathrm{C}$, tiras $d$ ). O soro anti- $\beta$-gal-B 13 também reconheceu bandas de 70 a $90 \mathrm{kDa}$ em epimastigoras (Figura 6A, tira $d$ ) e de 72 e $82 \mathrm{kDa}$ em tripomastigotas (Figura 6B, tira $d$ ). Essas bandas de menor peso molecular podem ser produtos de degradaçăo parcial da proteina, uma vez que não são visualizadas reprodutivelmente em experimentos feitos com diferentes lisados (comparar as tiras $d$ nas Figuras 6A e 6B com a tira $d$ da Figura 6C). Outra alternativa é que essas bandas representam antigenos que 
compartilham epitopos em comum. O soro anti- $\beta$-galactosidase reagiu com uma banda de cerca de $39 \mathrm{kDa}$ em epimastigotas (Figura $6 \mathrm{~A}$, tira b) e $60 \mathrm{kDa}$ em tripomastigotas (Figura $6 \mathrm{~B}$, tira b). Um soro normal controle não apresentou reatividade (Figuras $6 \mathrm{~A}, 6 \mathrm{~B}$ e $6 \mathrm{C}$, tira a).

3.9.2. Uso de anticorpos humanos imuno-selecionados

O peso molecular dos antigenos clonados foi confirmado por outra técnica. No item 3.8.2.4. foi relatado que uma mistura de soros humanos chagásicos reconhece as proteinas de fusão (ver Figura 5). Decidiu-se então proceder a um ensaio de imuno-seleção de anticorpos chagásicos e urilizá-los posteriomente em Western blot de T. cruzi. Esse ensaio foi realizado com a participaçāo de Paulo Germano Marmorato, estagiário de iniciação científica. Para isso, a fraçāo de IgG foi isolada a partir de uma mistura de soros chagásicos (ver item 2.18.2). Colunas de Sepharose foram acopladas às proteinas $\beta$-gal-B12, $\beta$-gal-Bl 3 e, como controle, à $\beta$-galactosidase (ver item 2.18.1). A eficiência de acoplamento foi de $66 \%$ para a $\beta$-gal, $58 \%$ para $\beta$-gal-Bl2 e $54 \%$ para $\beta$-gal-B13. As imunoglobulinas purificadas foram submetidas, seqüencialmente, a uma cromatografia de afinidade nas colunas de $\beta$ gal, $\beta$-gal-B12 e $\beta$-gal-Bl3, visando obter anticorpos especificos a epitopos de $\beta$-gal, BI2 $\epsilon$ B13, respectivamente (ver item 2.18.3). Os anticorpos eluidos com $\mathrm{pH}$ ácido foram utilizados em ensaios de Western blot. Na Figura 6D estão apresentados os resultados obtidos frente a um lisado de tripomastigotas. $O$ eluato anti- $\beta$-gal-B13 reconheceu bandas de 140, 120 e $35 \mathrm{kDa}$ (tira d). Anticorpos purificados de soros chagásicos, mas não submetidos à imuno-seleção, também reconheceram essas bandas (dados não mostrados). $O$ eluato anti- $\beta$-gal não demonstrou reatividade (tira $b$ ), assim como a IgG humana purificada de individuos normais e utilizada como controle (tira a). Esse resultado também foi encontrado para formas epimastigotas (dados não mostrados). O eluato anti- $\beta$-gal-B12. embora utilizado em várias condiçōes, não apresentou reatividade (tira c).

3.10. Determinação da localização celular em T. cruzi dos antígenos clonados

Tendo sido elucidado o peso molecular dos antígenos clonados, decidiu-se investigar se eles estāo presentes na superfície do parasita. Para isso, parasitas vivos tiveram as suas proteínas de superficie marcadas com Nal31 I, utilizando Iodogen como catalisador, conforme descrito no item 2.21.1. Formas epimastigotas e tripomastigotas radioiodadas foram lisadas e submetidas a ensaios de imunoprecipitaçāo, como relatado no item 2.21.2. Nesse caso também, visando reduzir o núvel de anticorpos anti-ß-gal gerados por todos os animais, realizaram-se imunoprecipitaçōes seqüenciais dos lisados de parasitas com os soros de coelhos anti- $\beta$-gal, anti- $\beta$-gal-Bl 2 e anti- $\beta$-gal-Bl3, respectivamente. Os resultados 


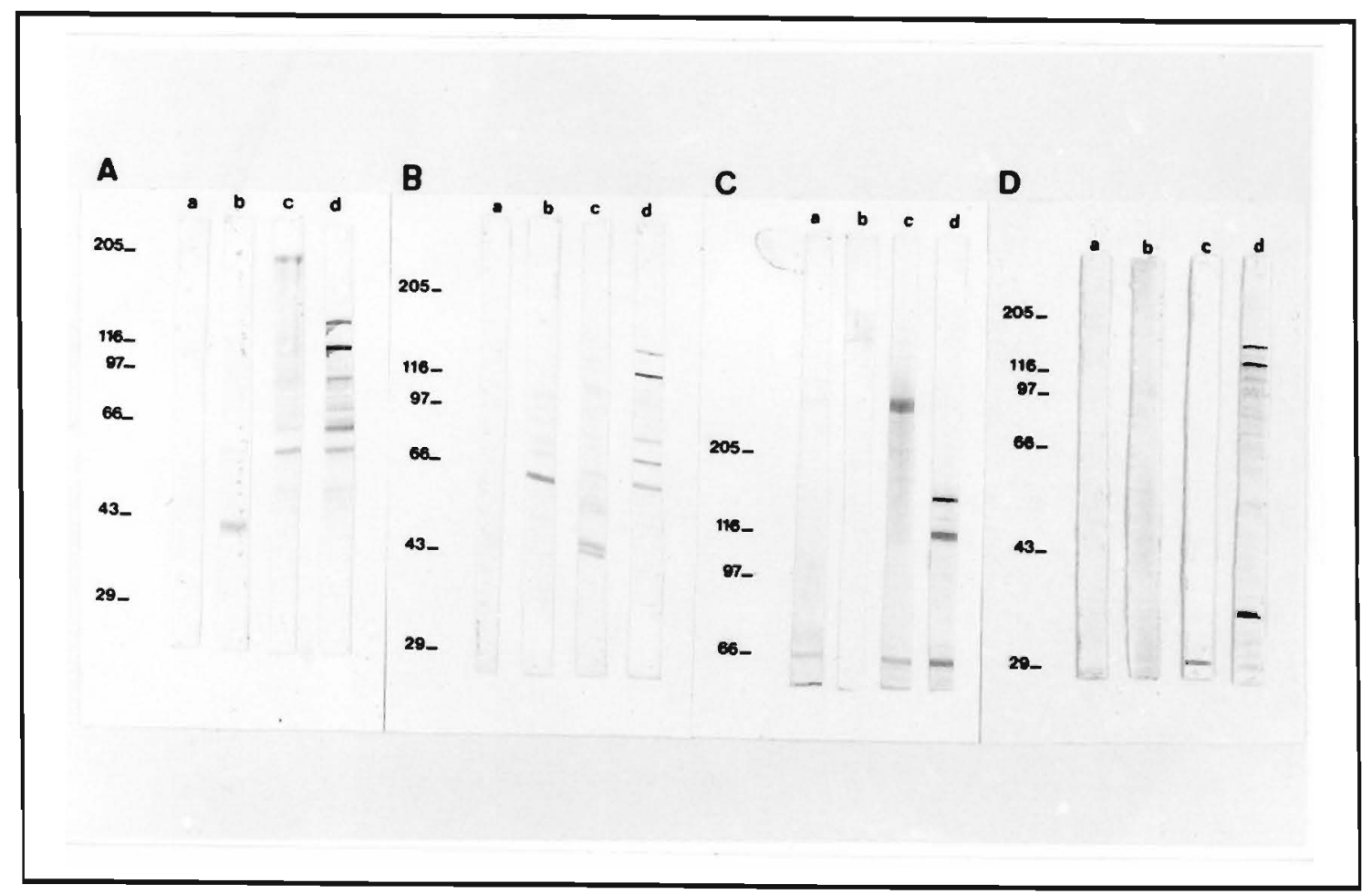

Figura 6 - Western blot de lisados de epimastigotas (A) e tripomastigotas (B, C, D) separados por SDS-PAGE em géis com $8 \%$ (A, B, D) ou 5\% (C) de acrilamida. Os filtros de nitrocelulose foram incubados com soros de coelho (A, B, C) ou com anticorpos humanos obtidos por imuno-seleção (D). Anticorpos: (a) normal; (b) anti- $\beta$-galactosidase; (c) anti- $\beta$-gal-B12; (d) anti$\beta$-gal-B13. Marcadores de peso molecular em quilodaltons estāo indicados. 
da imunoprecipitação de tripomastigotas são visualizados na Figura 7. Podemos verificar que os soros normal e anti- $\beta$-gal nāo reconheceram nenhum antigeno de superfície (canais $N$ e $\beta$ ). O soro anti-tct precipitou um grande número de bandas, na faixa de 66 a $180 \mathrm{kDa}$ (canal TCT). O soro anti- $\beta$-gal-B13 precipitou um antigeno de $140 \mathrm{kDa}$ (canal B13), gerando uma banda muito bem definida. Esse resultado foi confirmado em mais de um ensaio. Com relaçâo à localização celular de B12, o resultado da imunoprecipitação é inconclusivo. Na Figura 7 (canal B 12) podem ser visualizadas algumas bandas de intensidade fraca, na faixa de 150 a $170 \mathrm{kDa}$. Contudo, esse resultado nāo demonstrou reprodutibilidade. Em um ensaio de imunoprecipitação de formas epimastigotas, realizado com os soros anti- $\beta$-galB12 e anti- $\beta$-gal-B13, não se obteve a precipitação de nenhum antigeno de superficie (dados nāo mostrados).

3.1 1. Avaliação dos antígenos B12 e B13 no diagnóstico sorológico da doença de Chagas

\subsubsection{Padronização do radioimunoensaio}

O fato de as proteínas recombinantes serem reconhecidas por uma mistura de soros de pacientes chagásicos (ver Figura 5B) abriu a possibilidade de sua urilizaçāo para o diagnóstico sorológico da doença de Chagas. Nesse sentido buscou-se padronizar um método destinado à avaliação desses antígenos frente a um painel de soros humanos chagásicos e não chagásicos. Essa padronização foi realizada com a parricipação de Camila Bálsamo Ramalho, estagiária de iniciaçāo cientifica. A escolha do RlA para a mediçāo da resposta sorológica foi feita em funçāo de facilidades do laboratório para essa técnica. Contudo, como será visto adiante, o método pode ser adaptado para um ensaio de ELISA.

As proteinas de fusão, produzidas no sistema pMSgtl1/DH5 $\alpha$ e purificadas por afinidade, foram utilizadas para a padronização de um radioimunoensaio para diagnóstico da doença de Chagas. O RIA foi feito de acordo com o protocolo descrito no item 2.17.1. Inicialmente padronizou-se a quantidade de antígeno que deveria ser colocada em cada poço da microplaca. Para essa determinação, foram utilizados soros-padrão de indivíduos chagásicos e normais em ensaios onde se variou simultaneamente a quantidade de antigeno e a diluição dos soros. Em todas as etapas de padronizaçāo, os soros foram incubados em poços separados com a $\beta$-gal não recombinante para se ter uma avaliação da resposta imune a essa proteína. As curvas de calibraçāo demonstraram que massas de 20 a $30 \mathrm{ng}$ de antígeno por poço e diluiçōes de l:100 dos soros permitiam uma discriminação eficiente entre os soros normais e os chagásicos. Também se verificou que os soros normais e chagásicos apresentaram uma reatividade muito baixa frente à $\beta$-galactosidase. 


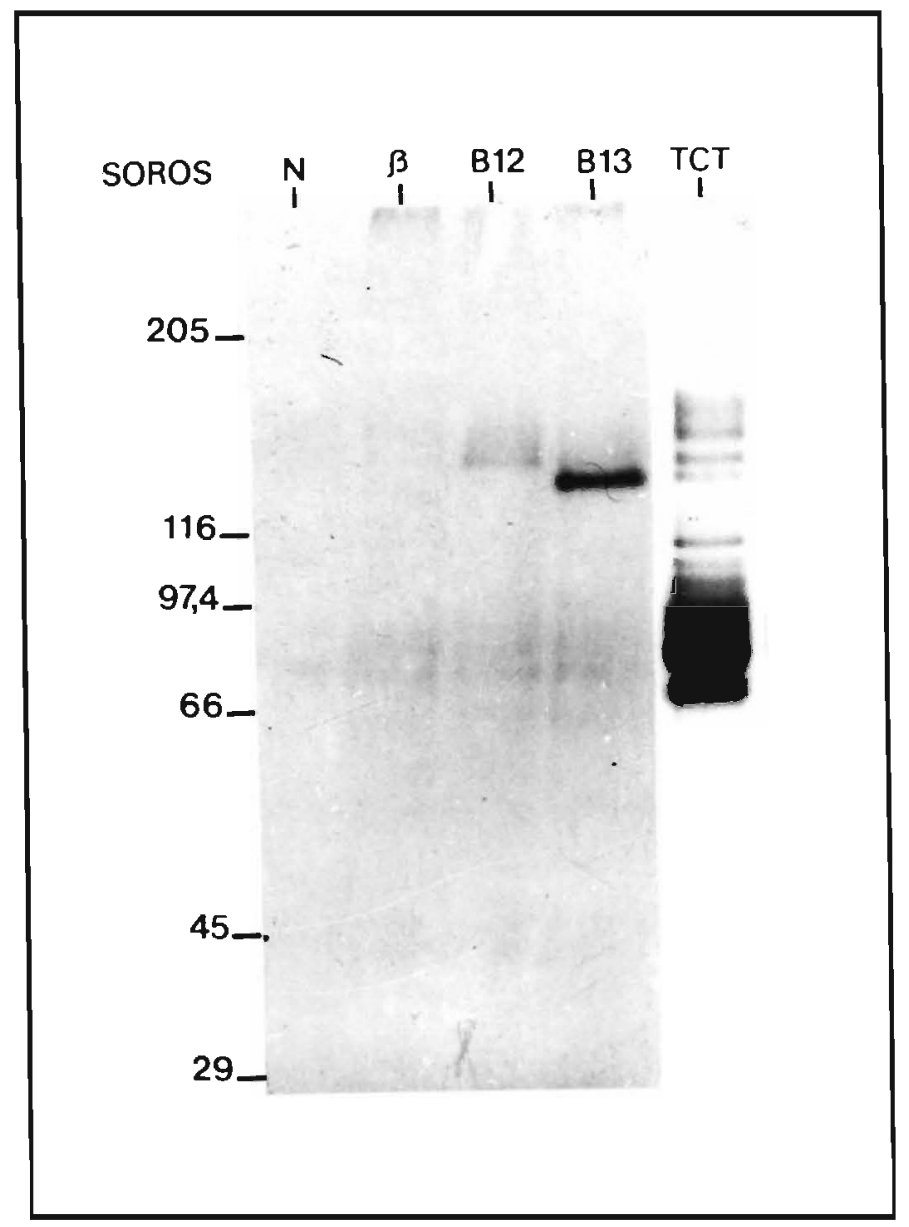

Figura 7 - Imunoprecipitaçāo de tripomastigotas radioiodados na superfície com $(\mathrm{N})$ soro normal de coelho; $(\beta)$ soro anti- $\beta$-gal; (B12) soro anti- $\beta$-gal-B12; (B13) soro anti- $\beta$-gal-B13; (TCT) soro anti-tct. Marcadores de peso molecular em quilodaltons estão indicados. 
3.11.2. Análise de reatividade de soros humanos por RLA

Tendo padronizado o método do RIA, decidiu-se fazer um levantamento com 128 soros, sendo 70 de pacientes chagásicos, 38 de pacientes com outras parasitoses e 20 de indivíduos normais. Nessas amostras, estão incluídos 50 soros fomecidos pela OMS (Organização Múndial da Saúde) para um estudo multicêntrico para a avaliação de antígenos recombinantes com fins diagnósticos (Luquetri, 1990). A análise estatística dos dados foi feita de acordo com o método adorado pela OMS para esse estudo (Moncayo \& Luquetti, 1990), empregando-se o índice $\mathrm{k}$ (Kappa), como descrito no item 2.17.3. Como podemos ver na Tabela I, o annigeno B12 obteve um índice Kappa de 0,61 , enquanto B13 obteve $\kappa=0,94$. Analisando a mesma tabela, podemos observar que $B 12$ apresenta um desempenho menos eficiente em relação a B13. O antígeno B12 obteve uma sensibilidade de $83 \%$ e uma especificidade de $78 \%$, enquanto que B13 apresentou $97 \%$ de sensibilidade e especificidade.

Em outros estudos realizados (Zingales et al., 1990; Gruber \& Zingales, 1993), foi observado que alguns soros chagásicos reconheciam um dos antigenos mas não o outro (indistintamente do antigeno ser B12 ou B 13). Isso poderia indicar que o reconhecimento de determinantes antigênicos pudesse estar relacionado com a forma de manifestaçāo clínica da doença de Chagas. Para testar essa hipótese, foram utilizados 37 soros de pacientes com diagnóstico clínico bem definido (13 cardiopatas, 13 assintomáticos e 11 com a forma digestiva). Nāo foi evidenciada nenhuma correlação entre a forma clínica e a reação preferencial com cada antígeno (dados não mostrados).

Em vista dos resultados descritos acima, decidiu-se investigar se a reatividade preferencial aos antígenos B 12 e Bl 3 poderia estar relacionada com o zimodema da cepa infectante de cada paciente. Utilizaram-se 12 soros da região de Bambuí MG, classificados de acordo com o zimodema da cepa de $T$. cruzi isolada do respectivo paciente (Romanha et al. 1979) e a manifestação clínica da doença de Chagas. Os resultados não indicaram correlaçāo entre a resposta a Bl2 e Bl3 e um zimodema particular (Gruber \& Zingales, 1993).

Finalmente, investigou-se a estabilidade do antígeno B13. A proteína de fusão, na concentração de $1 \mathrm{mg} / \mathrm{mL}$ em PBS, foi mantida à temperatura ambiente por até 2 semanas e a $-20^{\circ} \mathrm{C}$ até um período de 12 meses. Alíquotas, tomadas em diferentes tempos, foram utilizadas em testes de RIA com soros-padrão positivos e negativos. Os resultados demonstraram que o antigeno reteve sua sensibilidade e especificidade originais ao longo dos periodos testados. 
Tabela I - Reatividade das proteínas recombinantes $\mathrm{B} 12$ e Bl3 a soros de individuos normais, pacientes chagásicos e pacientes com outras parasitoses em radioimunoensaio.

\begin{tabular}{lccc}
\hline & & \multicolumn{2}{c}{ Reatividade $^{\mathrm{b}}$} \\
\cline { 3 - 4 } Soros humanos & & $\mathrm{B} 12$ & $\mathrm{~B} 13$ \\
\hline Positivos & $\mathrm{N}^{\mathbf{0}}$ de amostras & 58 & 68 \\
$\quad$ Doença de Chagas & 70 & & \\
Negativos & & 7 & 1 \\
$\quad$ Normal & 20 & 3 & 1 \\
Leishmaniose & 13 & 1 & 0 \\
Malária & 12 & 1 & 0 \\
Toxoplasmose & 8 & 1 & 0 \\
$\quad$ Esquistossomose & 5 & 0,83 & 0,97 \\
\hline Sensibilidade & & 0,78 & 0,97 \\
\hline Especificidade & & 0,61 & 0,94 \\
\hline Indice Kappa & & &
\end{tabular}

a Classificados como positivos e negativos de acordo com a sorologia convencional para doença de Chagas.

b Número de soros. 
3.11.3. Análise de reatividade de soros humanos por ELISA

Em função dos resultados promissores de Bl3, a empresa Polychaco S.A.I.C. (Argentina) propôs testar o antígeno em ELISA, uma técnica rotineiramente empregada em laboratórios clínicos. As condições de utilização foram padronizadas visando maximizar a eficácia natural de B13 em discriminar populaçōes humanas infectadas ou nāo por $T$. cruzi. Nesse estudo foram analisados 209 soros de individuos encaminhados por clínicos para um Centro de Referência (Instiruto Nacional de Diagnóstico de la Enfermedad de Chagas - Fatala Chaben, Buenos Aires, Argentina). Os resultados apresentados a seguir foram gentilmente cedidos pelo Dr. Jorge Yanovski e obtidos com reagentes da Polychaco e antígeno B13 produzido e purificado em nosso laboratório.

Esses soros foram analisados por hemaglutinação, aglutinaçāo direta, imunofluorescência direra e ELISA, todos empregando um lisado total de epimastigotas; e por ELISA com a proteína B13. Um toral de 124 amostras foram negativas para os testes convencionais e para B13. Em testes de ELISA, empregando $50 \mathrm{ng}$ de B13, essas amostras negativas apresentaram uma densidade ótica (D.O.) média de 0,107. A média de 99\% dos valores das amostras negativas, somada a três desvios padrão, permitiu definir um valor de corte ("cutoff") de 0,150. Um total de 85 soros foram considerados positivos para a doença de Chagas por sorologia clássica e por ELISA com B13. Para esse antigeno, 70\% das amostras positivas apresentaram valores de D.O. superiores a 0,550 , com uma média de 0,587 . Apenas 2 amostras $(2,3 \%)$ apresentaram uma D.O. de 0,160 , pouco superior ao valor de corte.

\subsection{Isolamento de clones a partir de uma biblioteca genômica em $\lambda$ EM[BL3}

Com o intuito de se isolar clones genômicos correspondentes aos clones B12 e B 13, utilizou-se uma biblioteca genômica de T. cruzi em $\lambda$ EMBL3 (construída por Monika Vieira de Arruda). A biblioteca foi plaqueada e clones positivos foram selecionados utilizando-se como sondas os insertos B12 e B13 marcados com [ $\alpha$-32P/dATP. Conforme descrito no item 2.11, foram utilizados dois filtros de nitrocelulose por placa, de forma que um deles era a réplica do outro. Cada um dos fútros foi hibridizado com uma das duas sondas. Foram obtidos 4 sinais positivos com a sonda Bl2 e 3 sinais com a sonda Bl3. Quando a localizaçāo desses sinais nas placas foi comparada, verificou-se que havia uma coincidência em 3 deles. Foram feitos replaqueamentos dos 4 sinais, visando a purificaçāo dos recombinantes. Uma vez puros, a hibridização de 3 desses clones genômicos com ambas as sondas, derivadas de B12 e 813 respectivamente, foi confirmada. Esses clones foram denominados BGE2, BGE7 e BGE14. O clone que hibridizou apenas com a sonda B12 foi denominado BGE9. 
3.13. Determinação do mapa de restrição de uma região de 32 kb

As amostras de DNA dos clones genómícos de $\lambda$ EMBL3 foram digeridas conforme o item 2.15.1. Para a elaboraçāo do mapa de restrição, foram escolhidas as enzimas BamHI, EcoRI, Hindlil, NcoI, Sall e Stul. Essa escolha se deveu ao fato de elas apresentarem poucos sítios de clivagem no vetor, sendo alguns deles próximos do sítio de policlonagem (Frischauf et al., 1987), o que facilita a dedução do mapa de restrição. Essas enzimas foram utilizadas isoladamente, ou em digestões duplas e triplas. As amostras de DNA digeridas com as endonucleases de restrição foram submetidas a um ensaio de Southem blot (ver itens 2.23.1 e 2.23.2). Para a hibridização, foram utilizadas sondas de fita simples, preparadas como descrito no item 2.12.2. Conforme pode ser visto na Figura 8, confirmouse o fato de os clones BGE 2, BGE 7 e BGE 14 apresentarem regiões homólogas aos clones B12 e B13. O clone BGE 9 somente apresentou hibridização com a sonda derivada do clone B12. A sobreposição dos mapas dos quatro clones genômicos permitiu elucidar o mapa de uma regiāo de $32 \mathrm{~kb}$ que contém os genes completos cortespondentes aos clones Bl2 e B13. Por convenção, designou-se uma numeraçāo para os sítios de restriçāo em ordem crescente, da esquerda para a direita do mapa. Os dois genes estão muito próximos e a distância entre os fragmentos homólogos a Bl 2 e B 13 é de cerca de 3 kb. A interpretaçăo final dos mapas de restrição dos clones de $\lambda E M B L 3$ mostra que houve deleçōes em grau variável nos clones BGE 7 e BGE 14 (Figura 8, linhas pontilhadas). Cultivos seriados do fago BGE7 e posteriores ргерагаções de seu DNA resultaram em deleções progressivas da regiāo que contém as repetiçōes seriadas homólogas a $\mathrm{B} 13$ (dados não mostrados). Esse resultado sugere que as deleções foram provocadas por um artefato de recombinação do sistema empregado e não devido a variaçōes presentes em diferentes células de uma populaçāo de $T$. cruzí. Esses aspectos serão melhor discutidos no item 4.5 .

Algumas regiōes do mapa de $32 \mathrm{~kb}$ tiveram que ser elucidadas com abordagens especificas. O fragmento de $5,35 \mathrm{~kb}$, compreendido entre os sítios $\mathrm{S} 2$ e $\mathrm{S} 3$ de Sall (consulte Figura 8), foi subclonado em pUCl8 com o objetivo de determinar o posicionamento relativo dos sitios internos de HindIII. Para isso, deduziu-se um mapa de restriçāo mais completo do fragmento \$2S3, em que o posicionamento dos sitios de HindIII foi obtido por comparaçāo com as posições de outros sítios de restrição (dados não mostrados). Para a elucidação dos sitios intemos de SaI, comprecndidos entre os sitios Ht e E2, subcionou-se o fragmento H4E2 do clone BGE7 (consulte Figura 8) no vetor pUC18. O DNA foi então digerido completamente com EcoRI ou com HindIII e parcialmente com Sall. Em função do tamanho dos fragmentos gerados pela digestào parcial foi possivel estabelecer as posiçōes relativas dos sitios $\$ 3, S 4$ e 55 (dados não mostrados). O sítio S1 (ver Figura 8) está 


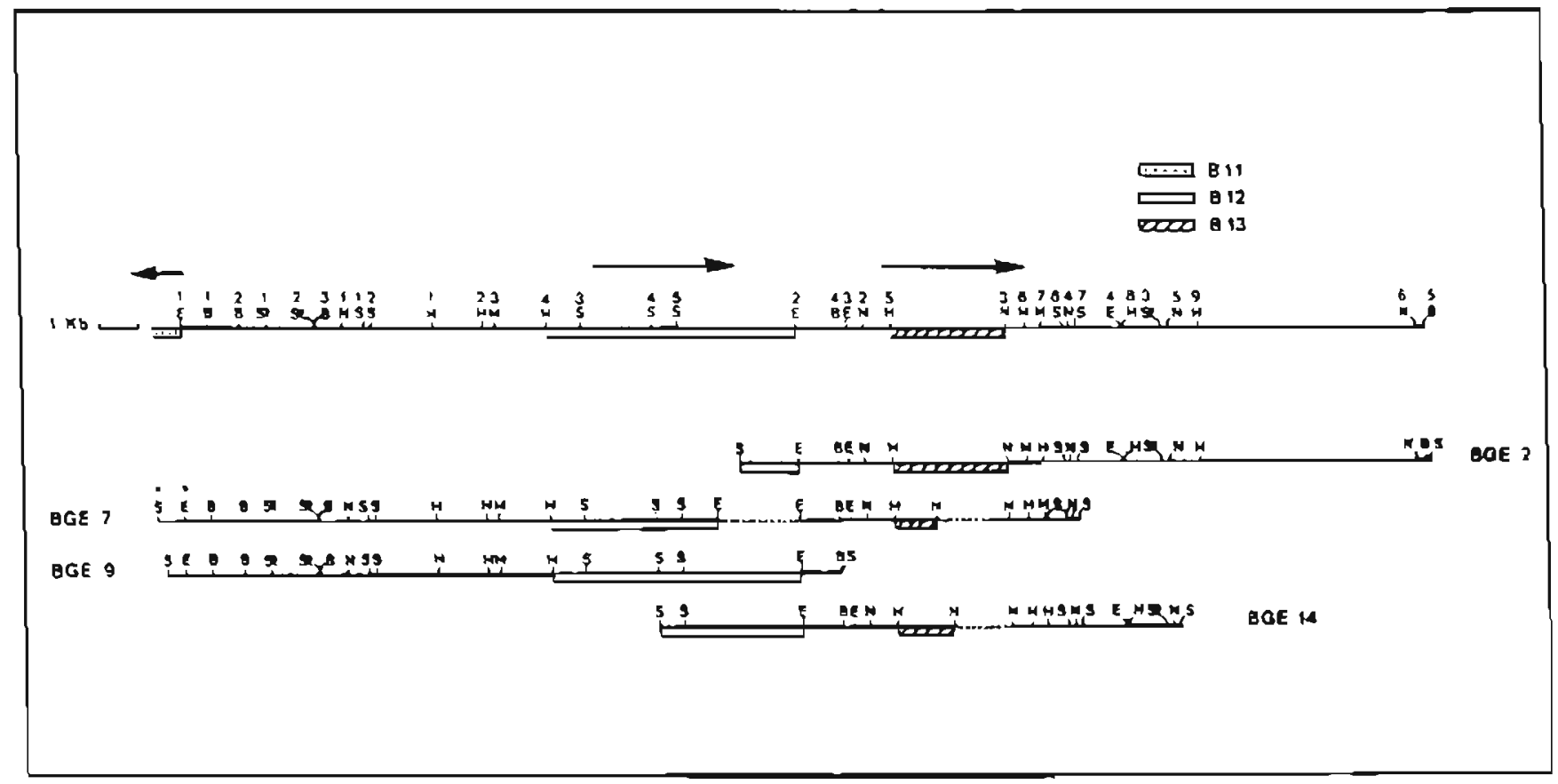

Figura 8 - Mapas de restriçāo dos clones genômicos BGE2, BGE7, BGE9 e BGEI 4 que contém as seqüências de repetiçōes seriadas homólogas aos clones Bl2 (quadro branco) e Bl3 (quadro hachurado). Também está mostrada a regiāo de $32 \mathrm{~kb}$ do genoma de $T$. cruzi coberta por esses clones. As letras e números e no mapa indicam a posiçāo dos sinos de restrição citados no texto. As linhas pontilhadas referem-se a regiōes de deleçōes nos clones. As flechas indicam o sentido de transcrição dos genes B11, B12 e B13 (ver texto). O fragmento SEl, discutido no texto, está assinalado com asteriscos (clone BGE7). Enzimas: B $=$ BamHI; $E=E c o R l ; H=$ HindII; $N=N c o l ; S=S a I ; S t=S t u I$. 
localizado a uma distância de cerca de 200 pares de bases do sítio S2. O fragmento S1S2 nunca chegou a ser visto em digestōes dos clones genômicos devido à sua massa reduzida em comparação ao resto do DNA do clone. Sua dedução se deve ao fato de a soma dos tamanhos dos fragmentos N1S1 e S2H1 ser 200 pb menor do que o fragmento N1H1. Para a confirmação de sua existência procedeu-se à subclonagem do fragmento ElHl em pUCl8. Quando uma massa de $3 \mu \mathrm{g}$ de DNA desse clone foi digerida com Sall, foi possivel visualizar um fragmento de tamanho compativel com o fragmento S1S2 (dados não mostrados).

Em virtude de os clones genômicos terem apresentado deleções, decidiu-se confirmar a proximidade física entre os genes B12 e B13 por meio de uma análise de Southern blot genômico de $T$. cruzi (ver Figura 9). Para isso, o DNA de T. cruzi foi digerido com Sall e hibridizado com B12, Bl3 e uma sonda feita a partir do fragmento E2B4 da região intergênica(consultar Figura 8 ). Conforme pode ser visto na Figura 9 , as sondas $\mathrm{B} 12$ (canal a), B13 (canal h) e E2B4 (canal b) hibridizaram com uma banda comum de 9,4 kb. Esse resultado confirma que os genes B12 e B13 estão fisicamente próximos no genoma do parasita. Além disso, a sonda intergênica E2B4 também foi hibridizada com os DNAs de $T$. cruzi (canal c) e dos clones genômicos BGE2 (canal d), BGE7 (canal e), BGE9 (canal e) e BGE14 (canal $\mathrm{g}$ ), digeridos com EcoRI e BamHI. Verifica-se que a sonda hibridiza com a mesma banda de 1,05 kb, correspondente ao fragmento E2B4 em todos os eventos. Esse resultado prova que a banda da região intergênica é comum a todos os clones genômicos e está presente no genoma do parasita.

\subsection{Expressão e purificação da proteína GST-S3S4}

\subsubsection{Construção do clone pGEX3X-S3S4}

A proteina de fusão B12 demonstrou uma eficiência bastante inferior à proteína B13 nos testes de RLA para o diagnóstico sorológico da doença de Chagas (vide item 3.11.2). Além disso, sua utilização como agente imunizante em coelhos induziu uma resposta humoral baixa (item 3.9.1). O clone pGEX3X-S3S4 foi construído com a finalidade de obterse a produção de uma proteína com maior quantidade de epitopos de B12 em relação àqueles presentes na proteína $\beta$-gal-B12. Decidiu-se subclonar o fragmento S3S4 (Figura 8), devido ao seu tamanho $(1,85 \mathrm{~kb})$ e por hibridizar com a sonda $\mathrm{B} 12$, no vetor de expressão pGEX3X (Smith \& Johnson, 1988), que expressa a proteína em fusão com a GST (glutationa $S$-transferase) de Schistosoma japonicum (uma proteina de $27,5 \mathrm{kDa}$ ).

Para esse propósito, utilizou-se um clone de $S 3 S 4$ no vetor pBluescript ${ }^{\otimes}$, previamente construido a partir do DNA de BGE7. Conforme relatado no item 2.16.3.1, o DNA de pBluescript ${ }^{2}$ foi digerido por Hincll. Essa enzima reconhece sítios de clivagem na 


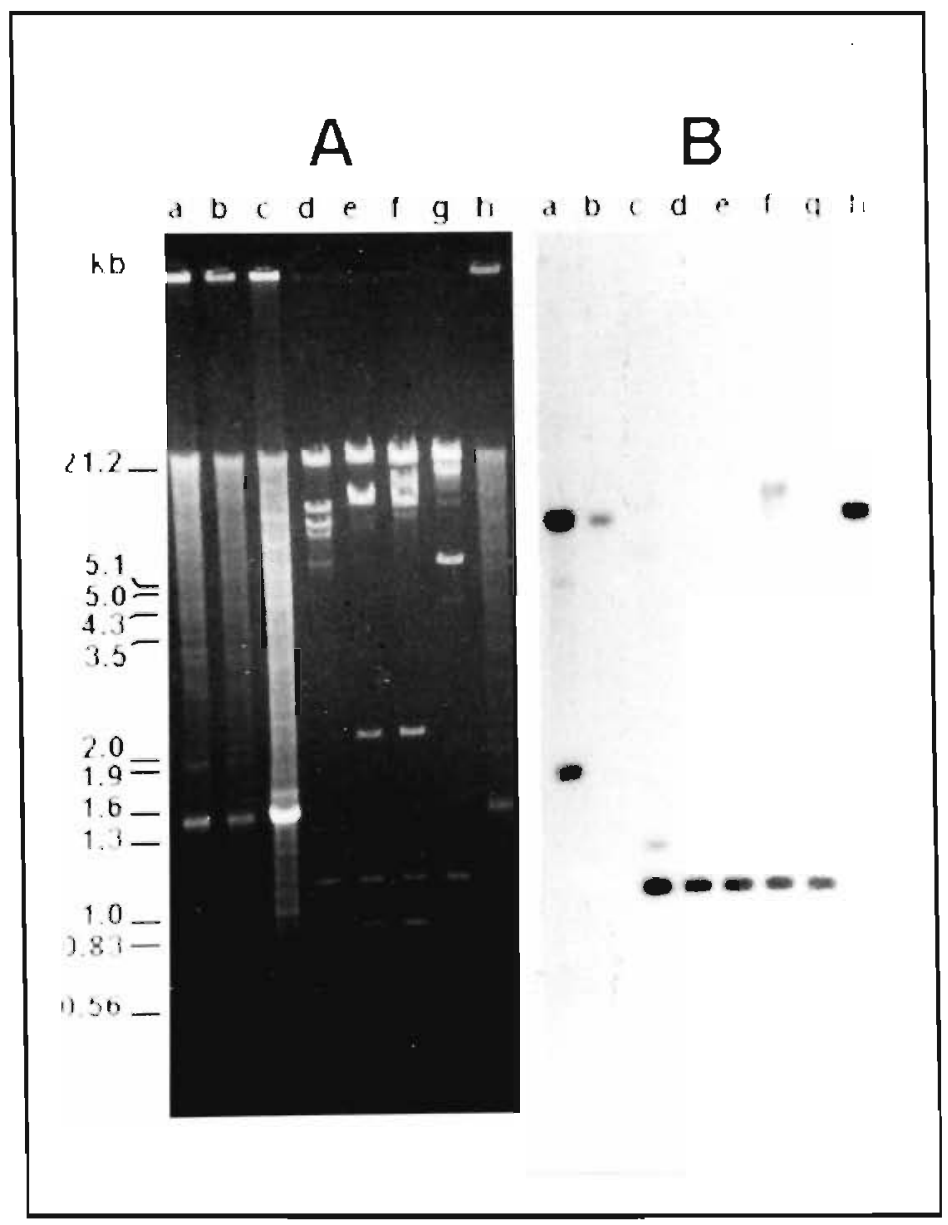

Figura 9 - (A) Padrão de digestão de DNA em gel de agarose 1,0\%. Amostras: (a, b, h) DNA de T. cruzi digerido com Sall; (c) DNA de T. cruzi digerido com BamHI e EcoRI; DNA dos clones (d) BGE2, (e) BGE7, (f) BGE9 e (g) BGEl 4 digerido com BamHI e EcoRI. (B) Southern blot hibridizado com as sondas (a) Bl2, (h) Bl3 e (b-g) E2B4 (ver Figura 8). Marcadores de peso molecular, em quilobases, são indicados. 
seqüência GTPyPuAC e, portanto, é capaz de clivar o mesmo sítio de restrição de Sall (GTCGAC). Como Hincll gera extremidades cegas, o fragmento pôde ser ligado aos adaptadores diretamente. A construção foi feita com três diferentes adaptadores para garantir a obtenção de um clone com o passo de leitura correto. O DNA do inserto foí lígado ao vetor pGEX3X e, após a transformaçāo na hospedeira DH5a e seleçào por imunoensaio de colônias (vide item 2.16.2.2), foram obtidos vários clones positivos.

\subsubsection{Expressāo da proteina de fusão GST-S3S4}

As células bacterianas foram cultivadas e induzidas como descrito no item 2.16.3.3.1. Experimentos de cinética demonstraram que o pico de produção ocorre 3,5 horas após a indução. Conforme pode ser visto na Figura 10, as bacterias induzidas (canal b) produziram uma proteína de cerca de $90 \mathrm{kDa}$, ausente nas bactérias controle nāo induzidas (canal a). Um ensaio de Western blot demonstrou que a proteína de fusão é reconhecida pelo soro anti-tct, assim como pelo soro anti- $\beta$-gal-B 12, provando que ela compartilha os mesmo epitopos de Bl2 (dados nào mostrados). Esse ensaio tambèm demonstrou que a proteína GST-S3S4 apresenta-se muito pouco degradada. O peso molecular de 90 kDa é compativel com o tamanho esperado da protcína de fusão.

\subsubsection{Purificação da proteína GST-S3S4}

Uma vez padronizadas as condições de expressão máxima de GST-S3S4, partiu-se para a purificação por cromarografia de afinidade. Obteve-se um lisado das bactérias conforme descrito no item 2.16.2.4. Como pode ser visto na Figura 10, a proteína GST-S3S4 está presente no lisado toral (canal c), entretanto cerca de $50 \%$ está na fração solúvel (canal d) e 50\% na fraçāo insolúvel do lisado (canal €). Quando esse sedimento foi tratado com uréia (vide item 2.16.2.5) foi possivel ressolubilizar a proteina. Entretanto, após diálises contra soluções de concentraçāo decrescente de uréla, a proteina reprecipitou. Além disso, quando o lisado contendo a fraçāo solúvel de GST-S3S4 foi congelado e depois degelado para utilização, ocorreu precipitação de uma fração significativa da proteína GST-S3S4. Esse fenômeno não ocorreu com a GST não recombinante, sugerindo que esse comportamento seja devido ao componente S3S4.

\subsubsection{Cromatografia de afinidade em resina GSH-agarose}

Os lisados contendo as proteinas na forma solúvel foram submetidos a uma cromatografia em glutationa-agarose em lote, conforme descrito no item 2.16.3.4.1.1. Para avaliar a porcentagem de proteína ligada à resina, foram feitas dosagens enzimáticas da 
atividade enzimática de GST do lisado ances e após a cromatografia (ver item 2.16.3.4.1.2). Tanto a GST-S3S4 como a GST não recombinante demonstraram atividade enzimática frente ao substrato CDNB, embora a última fosse nitidamente mais ativa. Essa abordagem prática permitiu monitorar facilmente o nivel de purificação, bem como o rendimento obtido.

No caso da GST, obtiveram-se ate $2,5 \mathrm{mg}$ de proteina pura a partir de um lisado derivado de $100 \mathrm{~mL}$ de cultura, sugerindo uma produção de cerca de $25 \mathrm{mg}$ de proteína por litro de cultura. Houve pouca ligaçào inespecifica de outras proteinas bacterianas à resina (dados não mostrados). No caso da proteína GST-S3S4, o rendimento máximo de ligação obtido foi de 1,25 mg por $\mathrm{mL}$ de resina, o que está muito abaixo da capacidade teórica de ligação $(8 \mathrm{mg} / \mathrm{mL})$. No lisado total ainda restou cerca de $50 \%$ da proteína recombinante. Quando o lisado foi recromatografado houve recuperaçāo adicional de GST-S3S4, porém com a contaminação de outras proteinas bacterianas. Concluiu-se que a afinidade da proteína recombinante pela GSH é muito inferior à GST original. A proteina GST-S3S4 pura, assim como observado no lisado rotal, precipitou após um ciclo de congelamento e degelamento. Para estocar a proteina sem ocorrer precipitaçào, adicionou-se $50 \%$ de glicerol à amostra, e guardou-se a $-20^{\circ} \mathrm{C}$.

\subsubsection{Purificaçăo da proreina GST-S3S4 por precipiração seleriva}

A proteina GST-S3S4 é produzida em grandes quantidades na bactéria DH5 $\alpha$, mas a sua baixa solubilidade dificulta seu uso em aplicaçōes como o radioimunoensaio destinado ao sorodiagnóstico. Decidiu-se portanto testar nos lisados bacterianos diferentes condições experimentais para verificar se ocorria aumento da solubilidade da proteina. Os resultados descrito abaixo foram obtidos por Cynnia Pereira, estagiária e bolsista de iníciação cientifica da FAPESP. Foram adicionados dois detergentes (SDS e Triton ${ }^{8} \mathrm{X}-100$ ) e um agente redutor (DTT) aos lisados bacterianos, conforme descrito no item 2.16.3.4.2.1. Se houvesse um aumento da solubilidade, seria esperada uma diminuição da proporção de proteina de fusão nos corpúsculos de inclusāo. Os resultados obtidos foram, de certa forma, surpreendentes. Os sobrenadantes dos lisados tratados com SDS com SDS/DTT foram depletados da proteína de fusão. Paralelamente, os sedimentos dos lisados tratados com os mesmos agentes retiveram grande quantidade da proteína de fusão. Lisados tratados com Triton ${ }^{\curvearrowright} x$ 100 e DTT nāo apresentaram alterações (dados nāo mostrados). Concluiu-se, portanto, que o SDS, na concentração de 0,03\% ocasionava a precipitação quase total das proteínas de fusão a partir da fração solúvel do lisado bacteriano.

Decidiu-se utilizar essa característica como estratégia de purificação da proteina. 0 lisado bacteriano foi previamente centrifugado e somente ao sobrenadante foi adicionado $0,03 \%$ SDS. A seguir esta fração foi novamente centrifugada e os respectivos sedimento e 
sobrenadante analisados. Na Figura 10 (canal f) observa-se depleção da proteína GST-S3S4 no sobrenadante e um sedimento contendo a proteina de fusāo praticamente pura (canal g). A identidade da proteina purificada pelo método descrito acima foi confirmada por meio de um ensaio de Western blot com o soro de coelho anti-tct, que reconhecidamente apresenta reatividade com os epitopos homólogos a Bl2, mas não àqueles da GST (dados nāo mostrados).

Para a posterior ressolubilizaçāo da proteina foram testados tampões com diferentes pHs, como descrito no item 2.16.3.4.2.2. Sedimentos da proteina insolúvel (correspondentes ao canal $g$ da Figura 10 ) foram ressuspensos nos diferentes tampões e incubados a $37^{\circ} \mathrm{C}$. A melhor ressolubiljzação, comprovada em géis de poliacrilamida (dados não mostrados), foi obtida com o tampão djetilamina pH 11,5. Resolveu-se então utilizar o tampão trietilamina (pH 11,5), que apresenta um ponto de ebulição menor do que o da dietilamina e pode ser removido mais facilmente. A lavagem do sedimento proréico por 3 vezes com tampão trietilamina pH 1 1,5, resultou em solubilizaçăo de cerca de $70 \%$ da massa total da proteína. Quando a proteína ressolubilizada foi dialisada contra um tampão de pH neutro, ocorreu nova precipitação. Decidiu-se então manter a proteína sempre em pH alcalino. Para a estocagem, foi verificado que soluções da proreína contendo $50 \%$ de glicerol e armazenadas a $-20^{\circ} \mathrm{C}$ mantiveram a solubilidade. Entretanto, soluções da proteina estocadas por alguns meses apresentaram elevado índice de degradação, conforme observado por SDS-PAGE.

3.15. Avaliaçāo do antigeno GST-S3S4 no diagnóstico sorológico da doença de Chagas

A proteína Bl2 apresentou um desempenho muito inferior ao antígeno Bl3 no diagnóstico sorolögico da doença de Chagas (ver item 3.11.2). Em vista disso, decidiu-se avaliar o desempenho da proteína GST-S3S4, que apresenta uma quantidade muito maior de epitopos de Bl2 em relação àqueles presentes na proteina Bl2 (ver Figura 8). Utilizou-se a proteína purificada por precipitação seletiva (ver item 3.14.3.2). A solução da proteina em trietilamina foi diluída cm PBS até atingir a concentração adequada para adsorção nos poços das microplacas (geralmente uma diluição superior a 1:100). Assim como já havia sido feito com os antígenos B 12 e B 13 , procedeu-se a uma curva de calibraçāo variando-se a massa de GST-S3S4 entre 50 a $200 \mathrm{ng}$ e a diluiçāo dos soros entre 1:50 e 1:200.

Utilizando alguns soros chagásicos e normais foi observada uma alta reatividade com a proreina. Entretanto, o ruído de fundo verificado com soros normais também foi bastante elevado. Ensaios realizados com uma GST nāo recombinante, purificada por cromatografia de afinidade, demonstraram que essa alta reatividade nào era devida ao reconhecimento dessa proteina pelos soros normais. A utilização de uma GST-S3S4 


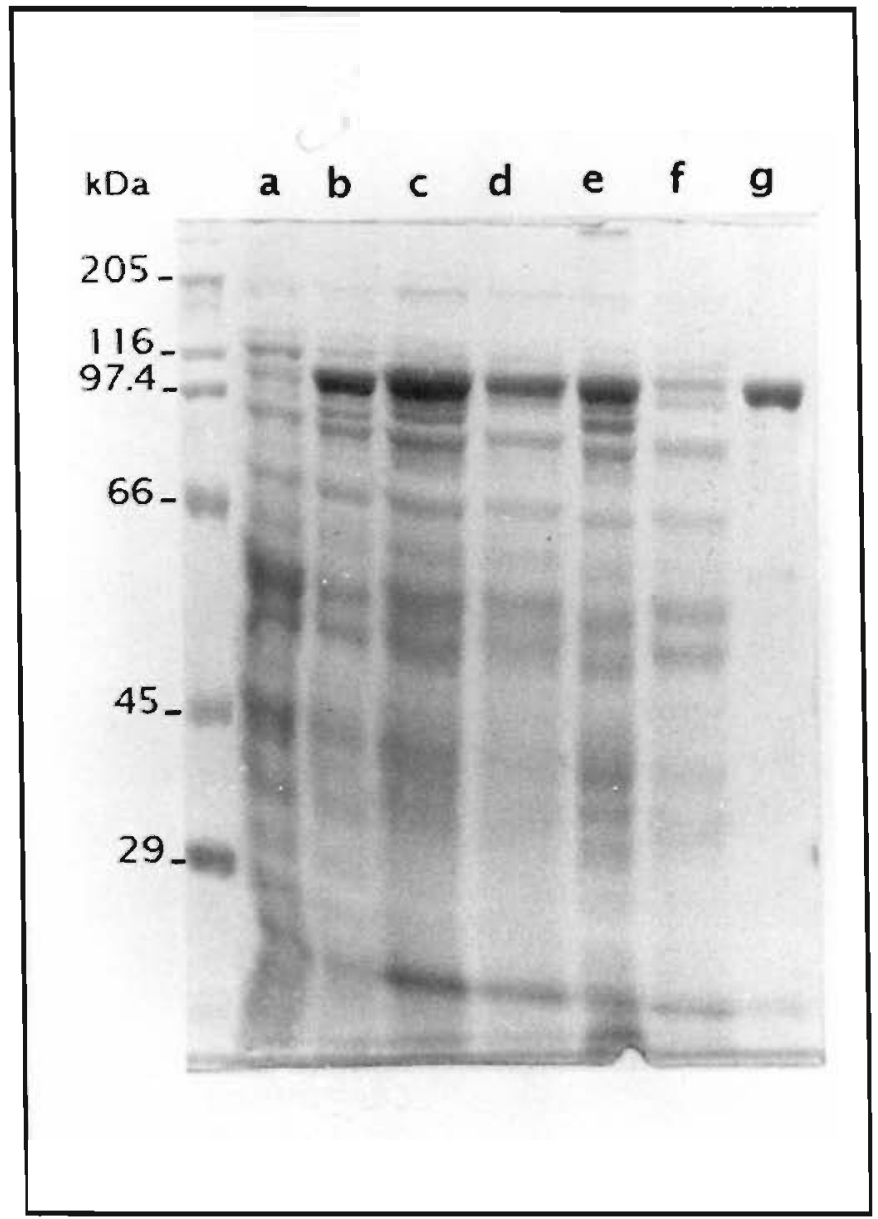

Figura 10 - Eletroforese em gel de poliacrilamida 7,5\% com SDS da bacteria DH5 $\alpha$ contendo o clone pGEX3X-S3S4. Amostras: (a) bactérias não induzidas; (b) bactérias induzidas; (c) lisado total de bactérias induzidas; (d) precipitado (fração insolúvel) do lisado bacteriano; (e) sobrenadante (fração solúvel) do lisado; (f) sobrenadante do sobrenadante tratado com $0.03 \%$ SDS; (g) precipitado do sobrenadante tratado com $0.03 \%$ SDS. Marcadores de peso molecular em quilodaltons. 
purificada por cromatografia de afinidade (item 3.14.3.1) também resultou em uma alta resposta inespecífica dos soros, indicando que esta era independente da forma cle purificação da proteína. Decidiu-se então diluis os soros a serem testados em uma solução de lisado bacteriano $(0,9 \mathrm{mg} / \mathrm{mL})$ e repetir os ensaios. Foi verificada uma grande queda na resposta inespecífica, sem alteraçāo da reatividade específica ao antígeno B12. Ensaios preliminares, realizados com 20 soros de pacientes chagásicos, demonstraram que a proteina GST-S3S4 apresenta menor atividade discriminatória do que a $\beta$-gal-B12. De fato, dos 20 soros com sorologia chagásica positiva, 16 foram considerados positivos com a proteína $\beta$-gal-B12 e somente 10 com a GST-S3S4.

$O$ conjunto de resultados desses ensaios preliminares, aliado à baixa solubilidade e estabilidade da proteína, parece indicar que a proteína GST-S3S4 nāo oferece nenhuma vantagem, em relação à $\beta$-gal-B12, quanto à utilização para o diagnóstico sorológico da doença de Chagas.

3.16. Utilização do soro anti-GST-S3S4 em Western blot de lisados de T. cruzi

Como foi relatado no item 3.9. I, a imunização com a proteína $\beta$-gal-Bl 2 resultou em soros com baixa reatividade ao antigeno $\mathrm{em}$ lisados de $T$. cruzi (ver item 3.9.1). Decidiu-se então imunizar coelhos (ver itens 2.7.2.2 e 2.7.2.3), em duplicata, com a proteína GST-S3S4 e, como controle, com a GST não recombinante. Os soros obtidos foram testados em Western blot com lisados de formas epimastigotas e tripomastigotas. Os soros anti-GSTS3S4 reconheceram um antigeno de peso molecular superior a $200 \mathrm{kDa}$ (dados não mostrados), como já havia sido observado com soros anti- $\beta$-gal-B12 (ver Figuras 6A e 6C, tira c). Esses soros reagiram fracamente com o Western blot de lisados de $T$. cruzi mas reconheceram inrensamente a proteína $\beta$-gal-B1 2 (dados não mostrados). Esse fato parece indicar que os soros anti-GST-S3S4 apresentam um bom título de anticorpos e a fraca reatividade observada diante dos lisados de $T$. cruzi pode ser devida à instabilidade e/ou baixa concentraçāo do antigeno na célula do parasita.

Um dado interessante é que os soros anti-GST reconheceram especificamente antígenos de 52 a $59 \mathrm{kDa}$ em epimastigotas e tripomastigotas (dados nāo mostrados). Esses soros reconheceram os mesmos antigenos em Western blots contendo proteínas de $T$. cruzi purificadas por afinidade em resina de GSH-agarose (dados não mostrados). Esses resultados, no seu conjunto, sugerem que as GSTs de $T$. cruzi $e S$. japonicum devem apresentar homologia e compartilhar alguns epitopos.

\subsection{Seqüenciamento dos genes $\mathrm{B} 12$ e 813}


O seqüenciamento de DNA foi realizado com a participação de Cyntia Pereira, estagiária e bolsista em nivel de iniciação cientifica pela FAPESP.

\subsubsection{Subclonagem de fragmentos dos clones genômicos}

Visando seqüenciar o gene Bl2 e a regiào intergênica entre Bl2 e B13, subclonaramse os fragmentos H4S3, S3S4, S455, S5B4, E2E3 e B4H5 (consultar mapa de restrição da Figura 8) no vetor pBluescript ${ }^{*}$. Para isso, o DNA do clone BGE7 foi digerido com HindIII e Sall e submetido à eletroforese em gel de LMP agarose. As bandas de H453, S3S4 e S4S5 foram purificadas conforme descrito no item 2.15 .3 e o DNA foi ligado ao vetor pBluescript ${ }^{*}$. Os fragmentos SSB4, E2E3 e B4H5 foram obtidos, pelo mesmo método, a partir do clone BGEI 4 digerido, respectivamente, com Safl/BamHI, EcoRI e BamHI/HindIII.

\subsubsection{Determinação do número e posiçāo das repetiçōes seriadas}

Os fragmentos H4S3, 5354, S4S5 e S5B4 (consultar Figura 8) apresentam, em géis de agarose, $0,85,1,85,0,65$ e 4,05 kb, respectivamente. O gene B12 apresenta na sua seqüência uma quantidade indeterminada de repetiçōes seriadas de 60 pares de bases (ver Figuras I e 8). Essas repetições estāo presentes nesses fragmentos, conforme foi confirmado previamente por hibridização. Com a finalidade de seqüenciar o gene Bl2, decidiu-se inicialmente determinar o posicionamento relativo das regiões com repetições, bem como estimar seu provável número. A partir dos dados de sequêncía obtidos originalmente no inserto do clone B12, foi verificado que há um sítio de Sacil (CCGCGG - consultar Figura l) em cada repetição. Como o vetor pBluescript ${ }^{\otimes}$ somente apresenta um sitio de Sacli no "polylinker", decidiu-se realizar digestões simples e múltiplas com SacII e enzimas do "polylinker". Isso permitiria determinar as distâncias entre as extremidades do inserto e as repetições seriadas, bem como a possivel existência de regiōes internas nāo repetitivas, mas flanqueadas por repetiçōes. As amostras de DNA digeridas foram separadas paralelamente em géis de acrilamida $6 \%$ e agarose $0,8 \%$, com a finalidade obter-se um bom nivel de resolução em diferentes faixas de tamanho (dados nāo mostrados). Além disso, foram feitos Southern blots desses géis e posterior hibridização com uma sonda B12 (composta somente de repetiçōes seriadas), objetivando identificar as bandas que contém as repetiçōes (dados não mostrados). Conhecendo-se o ramanho dos insertos e das regiōes nāo repetitivas, foi possivel calcular por, subtraçâo, o tamanho da região repetitiva $e$, consequientemente, o número aproximado de repetições seriadas. Esse dado é muito importante, pois a existência de repetições seriadas impede a localização exata do ponto de leitura em um dado subclone deletado por digestão unidirecional com Exonuclease III (ver a seguir). 
Conforme pode ser visto na Figura 11 o fragmento H4S3 (de 0,85 kb) apresenra uma região $5^{\prime}$ terminal de cerca de 500 pb, seguida de 3 repetiçōes seriadas e uma regiāo 3' terminal de cerca de $150 \mathrm{pb}$. O fragmento 5354 (de $1.85 \mathrm{~kb}$ ) apresenta uma região $5^{\prime}$ terminal de cerca de $380 \mathrm{pb}$, aproximadamente 22 repetiçōes seriadas e uma região $3^{\prime}$ terminal de $150 \mathrm{pb}$. No caso do fragmento S3S4 foi observado que nem todas as repetições seriadas apresentam o sítio de Sacil, indicando que há um certo grau de heterogeneidade entre elas. Em digestões de Sacll foi verificada a presença de fragmentos multímeros, contendo 120 e $180 \mathrm{pb}$ (dados não mostrados). O fragmento $\$ 455$ possui a mesma estrutura de S3S4, com exceção de somente possuir 2 repetiçōes seriadas. S5B4 contém a mesma regiāo $5^{\prime}$ terminal de 380 pb encontrada em 5354 e $\$ 455$ e um total de 40 repetiçōes. A regiāo 3' do clone 5584 apresenta um tamanho de $1,3 \mathrm{~kb}$ e contém sitios internos de HinclI e EcoRI (sítio E2 do mapa da Figura 8). A estrutura dos fragmentos H4S3, S3S4, S4S5 e S5B4 parece, portanto, ser muito semelhante e variar quanto ao número de repetiçōes seriadas. De fato, como será mostrado no seqüenciamento (Figura 12), os fragmentos compartham regiōes em comum.

\subsubsection{Seqüenciamento do gene B 12}

A seqüencia do gene B12 foi deduzida a partir dos fragmentos H4S3, S354, S4S5 e 55B4 (consulte Figuras 8 e 11). Visando a digestāo unidirecional com Exonuclease III (item 2.25.1), o DNA dos respectivos clones foi digerido com as enzimas Xhol e Kpnl, ou com BamHI e Sacl para a orientaçāo oposta. Após deleção, o DNA foi utilizado para transformar células competences da cepa JM 109 (ver item 2.15.5). As colônias foram então cultivadas e obtiveram-se preparaçōes rápidas de DNA ("speed-prcps" - ver item 2.14.2). As amostras obtidas tiveram a seqüência de somente uma base determinada ( $T$ ou $A$, conforme a orientação), como descrito no item 2.25.3.2. Subclones contendo sobreposiçōes de seqüência foram selecionados e utilizados para a obrenção de DNA por midipreparações (item 2.14.3) ou em larga escala por gradiente de cloreto de césio (2.14.4). Finalmente, procedeu-se ao sequienciamento completo nas quatro bases (ver itens 2.25.3.2) e com uma etapa adicional, utilizando a enzima TdT (item 2.25.3.3). A corrida eletroforética foi feita em um gel com gradiente de espessura (item 2.25.4.2).

No caso do clone S5B4 foram rastreados cerca de 70 subclones deletados em cada orientação, mas somente 4 deles continham regiões de interesse para o seqüenciamento. Os demais clones estavam deletados além do inserto, apresentando seqüências próprias do vetor. As reações de digestão unidirecional foram repetidas, mas obteve-se o mesmo resultado. Possivelmente o DNA original do clone 55B4 apresentava muitas quebras ("nicks"), o que por sua vez permitia a hidrólise por parte das enzimas Exonuclease III e nuclease S1, em diferentes pontos. Em função do problema acima e, a 


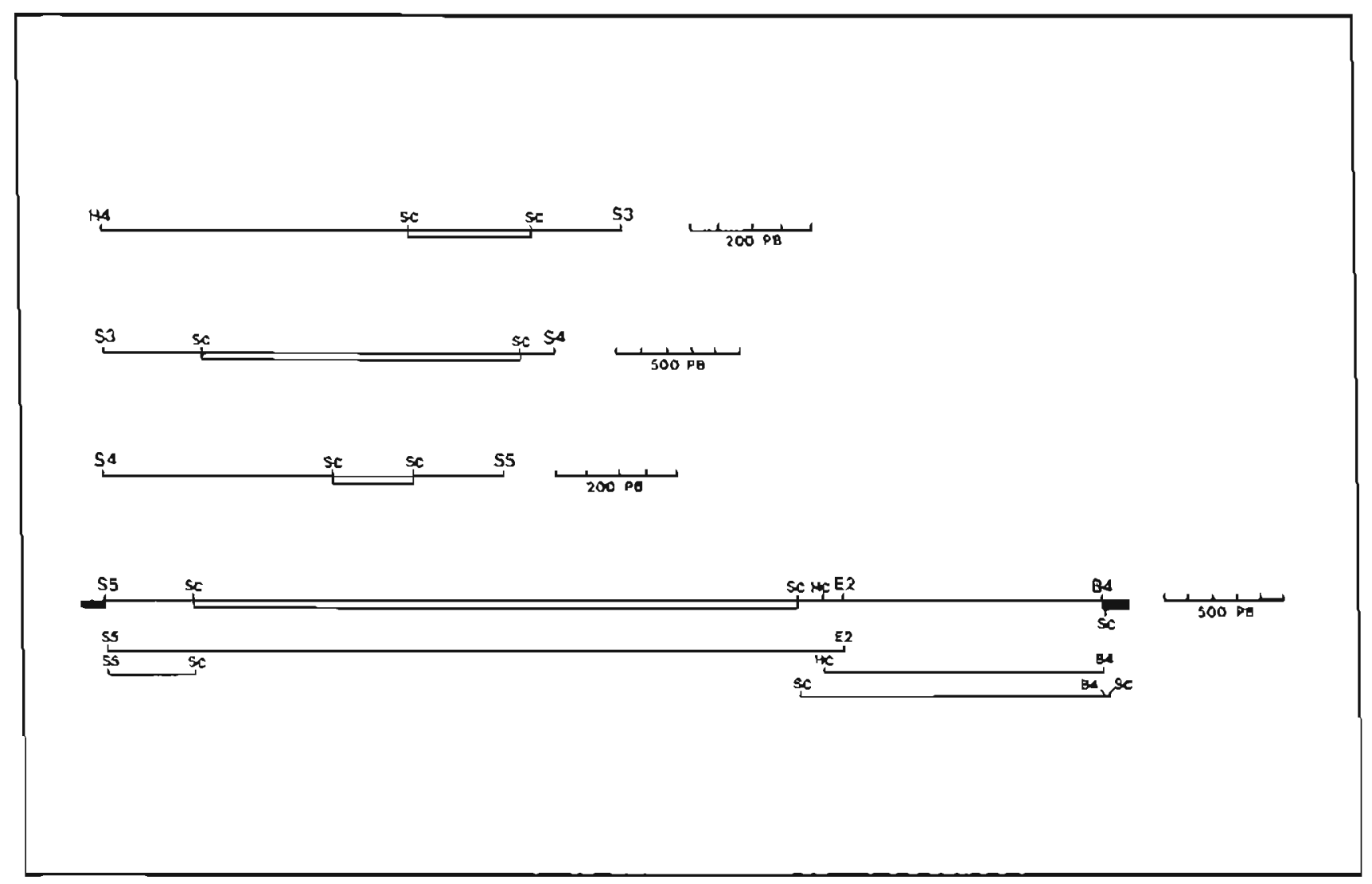

Figura 11 - Mapas de restrição dos fragmentos H4S3, S3S4, S4S5 e S5B4 do gene B12 (consultar Figura 8). As regiōes que contèm as repetiçōes seriadas cstão delimitadas pelos quadros brancos. Os quadros negros nas extremidades do clone S5B4 referem-se ao sítio de

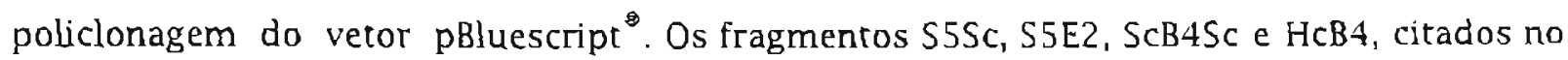
texto e derivados do clone S5BA, estāo apresentados. Enzimas: $B=B a m H I ; B s=B s p l 286 \mathrm{I}$; $\mathrm{E}=$ EcoRI; $\mathrm{H}=$ HindIII; $\mathrm{HC}=$ HinclI $\mathrm{S}=$ Sall; $\mathrm{SC}=$ SacIl. 
partir dos dados do mapa de restriçăo do fragmento S5B4 (Figura 11), decidiu-se fazer construções derivadas desse clone. O DNA foi digerido com Sall/EcoRI, Sacil e Hincll e os respectivos fragmentos liberados, S5E2 e ScB4Sc (consulte Figura 11), foram purificados e subclonados no vetor pBluescript ${ }^{\circledR}$. O DNA do clone S5B4 digerido com HinclI, livre do fragmento S5Hc, foi religado de forma a gerar o subclone HcB4 Abordagem similar, utilizando digestāo com SacII, foi empregada para obter o clone S5Sc. A partir desses clones foi possivel determinar a seqüência nucleotidica do fragmento $55 E 2$, sem a necessidade de se promover deleções seriadas pelo método de Henikoff (1987). A sobreposição dos dados permitiu elucidar a seqüencia, nas duas fitas, da região 3' terminal do clone S5E2. A região 5 ' terminal do clone S5E2 foi determinada, nas duas fitas, a partir do seqüenciamento do subclone S5Sc nas duas orientaçōes. Além disso, também foram urilizados na conclusāo da seqüência os 4 subclones deletados de 55B4, mencionados anteriormente. O DNA do clone HcB4 (ver, Figura 11) foi digerido com as enzimas Xhol/Kpnl e BamHl/SacI e, posteriomente, submetido à digestão unidirecional com Exonuclease III. Subclones deletados foram obtidos como descrito acima e seqüenciados. A sobreposição dos dados perminu elucidar a seqüencia completa do fragmento, concluindo assim a regiào $3^{\prime}$ do fragmento original 55B4.

\section{Página seguinte:}

Figura 12 - Seqüência nucleotidica da região compreendida entre os sítios $\mathrm{H} 4$ e B4 (consultar Figura 8), que inclui o gene Bl2 e parte da regiăo intergênica. Os sítios de restrição H4, S3, S4, 55, E2 e B4 estão indicados em negrito, assim como os supostos códons de iniciação (ATG - posição 372) e terminaçāo (TGA - posiçāo 6.714) do gene Bl2. Três códons de terminação (TGA - posição 252, TAA - posição 282 e TAG - posição 288) na regiāo "upstream" do códon de iniciaçāo também estão assinalados em negrito (ver texto). As flechas indicam prováveis sítios de "trans-splicing". As regiōes demarcadas por quadros cheios referem-se às repetiçōes seriadas de $60 \mathrm{pb}$. Os quadros tracejados indicam repetiçōes incompletas ou degeneradas. A rradução protéica da ORF do gene Bl2 também está apresentada. A continuaçāo dessa seqüência, a partir do sítio B4, está apresentada na Figura 14. 
Hind III (BA)

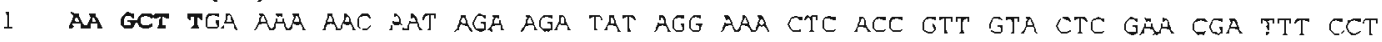

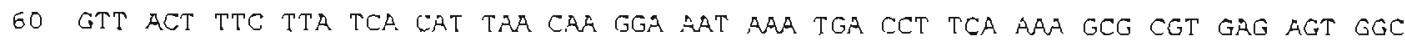

420 TCC AGA MAA RAA GAC GAA ACT AAC RTT ACA TTC RGC RAT ACA GTA AAC CCA ANA AAA ACC

17 Ser Arg Lys lys His Glu Thr Asn Ile thr the Ser Asn thr Val Asn bro Lys Lys Thr

480 TCT TCA GAT AAT GAG ANA ECG CCC GCG GAG TCT CCT TTC AAG AGC GTG TTT GGA GCA CEG

37 Ser Ser Asp Asn glu Lys Ero Pro Ala Glu ser Pro phe l.ys ser val phe Gly Rla Pro

540 TCT TCG ACT GCT GCG AR̈G CCA GCC GCG JAG TCT CCT TTC AAG AGC GTG TTT GGA GCA CCG

57 Ser Ser The Ala Ala lys pro Pco Ala Glu jer ero phe lys ser val ehe jly Ala ero

600 TCT TCO ACT GAT FCA RAG CCA CCC GCG GAG TCT CCT TTC AAG AGC ITG TTT GGA OCA CCC. Ser ser The Asp Ala Lys Pro Pro Alo Glu ser Pro phe Lys Ser val She Gly Ala fro

660 TCS TCG ACT GRT GCA AAG CCA CCE GCG GAG TTA GCT GTG ARG GAG TTG LGA GCE ACO TCC

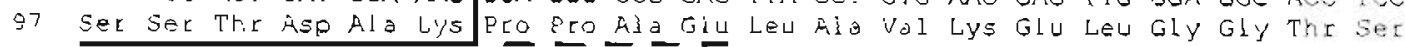

T20 TGT GGC ALA AAT GGA GTG TGG AAA TOT TCC CGT TGT GGT AAG GCA AAG GRT CTT TCT GGA

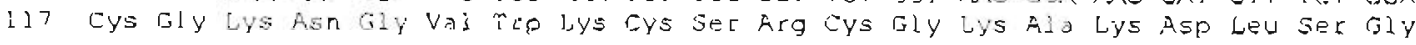
Sal I (53)

780 GAA CAT TTA ARA RAT AAI ACT GAA GTA CGE TCC GAC TGT TGG CCG TGC GCG aGG AAG TCG

$\$ 37$ Glu hls leu lys ásn lys thr glu val Aro ser Asp cys top pro Cys ala Arg lys Sel

840 aCA tTE ATA CTG GAA AGG GAA ARA TTG TCG GTA TGT ISGA AAA CRG GAT GTG GRT GAA GRT

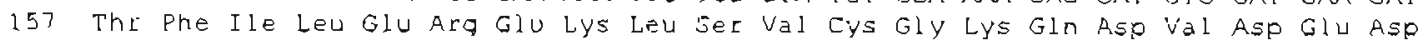

900 GAT AAC AGA RAG CCC GTG ATC RAT TTA TCT TCA RCG TCA GGG GGT GTG PAA GCE GTA GTG

177 Asp Asn Rrg lys 8co Val I le Asn leu ber Ser The ser Gly Gly Val lys Ala Val Val

960 GCG TTT GAG COT CCA CET AT'T CCG GTA GAA GCG GAG GAG CAT ETA TTT CTT TTC CCT RAT

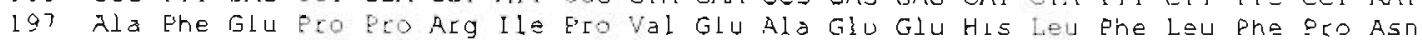

1020 GTT GGG GAC AAA AAG GAG ACR R2G GAA TCC GAG AGC RGT TCC TCT TAT ATC TGG RGG TGT

217 Val Gly Asp lys lys Glu The lys Glu Ser Giu Ser Sel See Ser Tyr Ile Trp Arg gys

1080 CGO GTT TST GAC AAG GTA RAG CAA CTA GCC GGA CAA CAC CTG AGC GGA AAL ACG GAA GTT

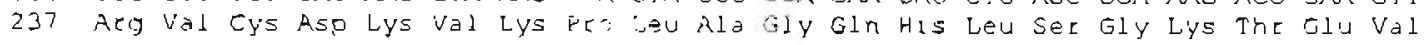

1140 AGA AGC GAC TO? TGG “. TG TGT GCA GCA MAG GGT ACC TTC TAC COA ACG GCA ACT CAA aAC

25? Arg Ser Asp Cys Trp Pro Cys Ala Ala lys Arg The the Tyr Arg Thr Ala Thr gln Asn

1260 TCG ACT GCT GCG AAI CCA CCC GCG GAG TCT CCT TTC AGG RGC GTG TTT GGA GCA CCG TCT

297 Ser Thr Ala Ala Lys Pro oro Ala Glu ser Pro phe Arg Ser Val Phe Gly Ala ero Ser

2280 GCG AAG CCA CAC GCG GAG TCT CCT TTC AAG AAC GTG TTT GGA GCA CCG TCT TCG ACT GAT

637 Rla Lys Pro His Ala Glu jer pro the Lys Asn Val phe Gly Ala pro ser Ser Thr Asp

2340 GCG AAG CCA CCC GCG GAG TCT CCT CTC AAG AGC GTG TTT GGA GCA CCG TCT TCG ACT GCT

657 Ala Lys Pro Pro Ala Glu Ser pro leu Lys Ser Val phe Gly dla Pro Ser Ser Thr Ala

2400 GCG AAG CCA CAC GCG GAG TCT CCT TTC AAG RAC GTG TTT GGA GCA CCG TCT TCG ACT GCT

677 Ala lys Pro His Ala Glu ser pro phe Lys Asn Val phe Gly Ala Pro ser Ser Thr Ala

2460 GCG AAG CCA CCC GCG GAG TCT CCT CTC AAG AGC GTG TTT GGA GCA CCG TCT TCG ACT GAT

697 Ala lys Pro Pro Ala Glu Ser pro leu lys Ser Val phe Gly Ala pro Ser Ser Thr Asp 
2520 GCA AAG CCA CCC GCG GA. TTA GCT GTG AAG GAG TTG GGA GGC RCC TCC TGT GGC AAA AAT

717 Ala Lys Pro Pro Ala Glu Leu Ala Val Lys Glu Lel Gly Gly Thr Ser Cys Gly Lys Asn

2579

736

2580 GGA GTG TGG AAA TGT TCC CGT TG: GGT AAG GCA AAG GAT CTT TCT GGA GAA CAT TTA ARA

737 Gly Val Trp Lys Cys Ser Arg Cys Gly Lys Ala Lys Asp Leu Ser Gly Glu His Leu Lys $S A I I$ (S4)

2640 AAT AAG ACT GAA GRA CGC TCC GAC TGT TGG CCG TGC GCG AGG AAg tCG ACA TTC ATA CTG

757 Asn lys The Glu Vai Arg Ser Asp Cys Tro ero Cys Ala Arg Lys Ser Thr Phe Ile Leu

2700 GAA AGG GAA AAA TTG TCG GTA TGT GGA. AAA CAG GAT GTG GAT GAA GAT GAT AAC AGA AAG

777 Glu Arg Glu bys Leu Ser Val Cys Gly lys Gln Asp Val Asp glu Asp Asp Asn Arg Lys

2760 CCC GTG ATC AAT TTA TOT TCA ACG TCA GGG GGT GTG AAA GCC GTA GTG GCG TTT GAG CCT

797 Pro Val Ile Asn Leu Ser Ser Thr Ser Gly Gly Val Lys Ala Val Val Ala Phe Glu Pro

2820 CCA CGT ATT CCG GTA GAA GCG GAG GAG CAT CTA TTT CTP TTC GCT AAT GTT GGG GAC AAA

817 Pro Arg lle ero Val Glu Aia Giu Glu His leu phe Lew Phe Pro Asn Val Gly Asp Lys

2880 AAG GAG ACA AAG GAA TCC GAG AGC AGT TCC TCT TAT ATC TGG AGG TGT GGT GTT TGT GAC

837 Lys Glu Tre lys Glu ser Glu Ser ser ser ser Tyr Ile Trp Arg Cys Arg Val Cys Asp

2940 AAG GTA AAG CCA CTA GCC GGA CAA CAC CTG AGC GGA AAG ACG GAA GTT AGA AGC GAC TGT

857 Lys Val Lys ero Leu Ala Gly Gln His Leu Ser Gly bys Thr Glu Val Arg Ser Asp Cys

3000 TGG CCA TGT GCA GCA AAG CGT ACC TTC TAC CGA ACG GCA ACT CAA AAC ACA TTC ACT GCG

877 Trp Pro Cys Ala Ala Lys Arg The Phe Tyt Arg Thr Ala Thr Gin Asn Thr Phe Thr Ala

3060 त̄̄G CCA CAC GCG GAG TCT CCT GTC AAG AAC GTG TTT GGA GCA CCG TCT TCG ACT GCT GCG

897 Lys Pro His Ala Glu Ser Pro Leu Lys Asn Val Phe Gly Ala fro Ser Ser Thr Ala Ala

3120 AAG CCA CCC GCG GAG TCT CCT TTC AAS AGC GTG TTT GGA GCA CCG TCT TCG ACT GAT GCA

917 Lys Pro Pco Ala Glu ser fro the Lys Ser Val phe Gly Ala Pro Ser Ser Thr Asp A.

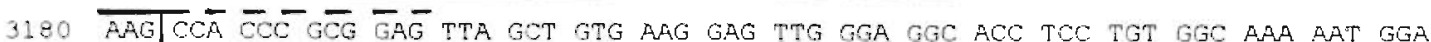

937 Lys Pro Pro Ala Glu Leu Ala Val Lys Glu Leu Gly Gly Thr Ser Cys Gly Lys Asn Gly

3240 GTG TGG AAA TGT TCC CGT TGT GGT AAG GCA AAG GAT CTT TCT GGA GAA CAT TTA AAA AAT

957 Val Trp Lys Cys Ser Arg Cys Gly Lys Ala Lys Asp Leu Ser Gly Glu His Leu Lys Asn $\operatorname{SaI} I(\mathrm{~S} 5)$

3300 RAG ACT GAA GTA CGC TCC GAC TGT TGG CCG TGC GCG AGG AAG TCG ACA TTC ATA CTG GAA

977 Lys Thr Glu Val Arg Ser Asp Cys Trp pro Cys Ala Arg Lys Sec thr Phe Ile Leu Giu

3360 AGG GAA AAA TTG TCG GTA TGT GGA AAA CAG GAT GTG GAT GAA GAT GAT AAC AGA AAG CCC

997 Arg Glu lys leu Ger Val Cys Gly uys Gln Asp Val asp glu Asp Asp Asn Arg lys pro

3420 GTG ATC AAT TTA TCT TCA ACG TCA GGG GGT GTG AAA GCC GTA GTG GCG TTT GAG CCT CCA

1017 Val te Asn Leu Ser Ser Thr Ser Gly Gly Val Lys Ala Val Val Ala ehe Glu pro pro

3480 CGT ATT CCG GTA GAA GCG GAG GAG CAT CTA TTT CTT TTC CCT AAT GTT GGG GAC AAA AAG

1037 Arg ile pro Val Glu Ala Glu Glu his leu the Leu the pro Asn Val Gly Asp lys lys

3540 GAG ACA AAG SAA TCC GAG AGC AGT TCC TCT TAT ATC TGG AGG TGT CGC GTT TGT GAC BAG

1057 Glu Thr Lys Glu Ser Glu ser ser Ser ser Tyr Ile Trp Arg Cys Arg Val Cys Asp Lys

3600 GTA AAG CCA CTA GCC GGA CAA CAC CTG AGC GGA AAG ACG GAA GTT AGA AGC GAC TGT TGG

1077 Val Lys pro leu Ala Gly Gln His Leu Ser Gly Lys thr Glu Val Arg Ser Asp Cys Trp

3660 CCA TGS GCA GCA AAG CGT ACC TTC TAC CGA ACG GCA ACT CAA ABC ACA TTC ACr GCG AAG

1097 Ero Cys Ala Ala Lys Arg The Phe Tyr Arg Thr Ala Thr Gln Asn Thr Ehe Thr Ala iys

3720 CCA CCC GCG GAG TCT CCT CTC AAG AGC GTG TTT GGA GCA CCG TCT TCG ACT GCT GCG AAG

1117 Pro pro Ala Glu ser pro leu Lys ser Val Ehe Gly Ala pro ser Ser Thr Ala Ala Lys

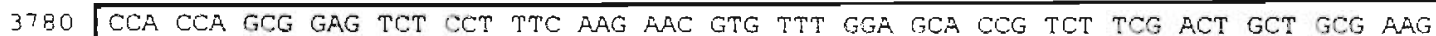

1137 Pro Pro Ala Glu ser Pro phe Lys Asn Val phe Gly Ala pro ser Ser Thr Ala Ala Lys.

3840 CCA CCC 1 CG GAG TCF CCT TTC AAG AGC GTG TTT GGA GCA COG TCT TCG ACT GAT GCA RAG

1157 Pro Rro A:a Glu ser Pro Phe Lys Ser Val phe Gly Ala pro ser Ser mhr Asp Ala Lys

3900 CCA CCC GCG GAG TCT CCT TTC AAG AAC GTG TTT GGA GCA CCG TCT TCG ACT GCT GCG AAG

1177 Pro ero Ala Glu Ser gro phe Lys Asn Val phe Gly Ala gro ser ser Thr Ala Ala Lys 
5880 CCA CCC GCG GAG TCT ECT CTC AAG AGC GTG TTT GGA GCA CCG TCT TCG ACT GCT GCG AAG

1837 Pro Pro Ala Glu Ser zro Leu lys Ser Val phe Gly Ala Pro Ser Ser Thr Ala Ala lys

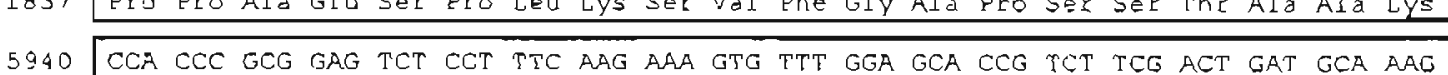

1857 Pro pro Ala Glu ser fro ehe lys lys Val the Giy Ala pro ser ser thr Asp Ala lys

1856

6000 CCA CAC GCG GAG TCT CCT CTC AAG AGC GTG TTT GGA GCA CCG $T$ TT TCG ACT GCT GCG ARG

1877 Pro His Ala Glu ber Pro Leu bys Ser Val phe Gly Ala Pro Ser ser Thr Ala Ala Lys

$6 0 6 0 \longdiv { C C A }$ CCC GCG GAG TCT CCT TTC RAG AAC GTC TTT GGA GCA CCG TCT TCG AAT GCT GCG AGG

1897 Pro Pro Ala Glu Ser Pro phe Lys Asn val Phe Gly Ala Pro Ser Ser Asn Ala Ala Aca

6120 GTC TCG GAA GAT TCT TCA TTA AGT GTT GTT TCT CAC TTG ATG CCA 'TTT GGT GTC GGT GAT

1917 Val Ser Glu Asp ser ser leu Ser Val Val Ser his leu Mer pro phe gly val Giy Asp

6180 GGC GGG GCT GTC GCT TTG ATT CCT TCA GAG GGT TCA TTT GCA GGS CGC TCT GAA GTT AGT

1937 Gly Gly Ala Val Ala Leu ile pro ser Glu Gly Sec the Aía Gly Arg Ser Gilu Val Ser

6240 TCG GRT GCA AGT GCT TTT GTT GAC CCT ATG RTT CCT TCT GAC GAC GAT GTT AAT GGG TGT

1957 Ser Asp Rla ser Ala the val Asp pro Met Ile gro ser Asp Asp Asp Val Asn gly Cys ECORI (E2)

6300 BAT AGT TTG GTT TAT RAA GAA GCT ATG GGA GAA ÂTG AAT TCC GGT T'TT ATG TTT CCT CTT

1977 Ast Ser leu Val Tyr lys Glu Ala Met gly glu Mer Asn Ser Giy ghe Met phe pro lew

5239

1956

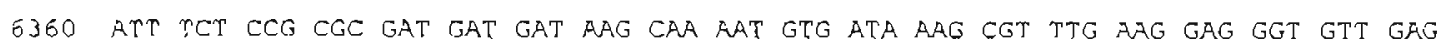

1997 ile ser pro Arg Asp Asp Asp lys gin Asn Vad zle lys Arq leu lys Glu Gly val Glu

5420 AAA ATA TCT TTT GAT GGA GTG AGA RRT GAG CCT TTA GTT GTS GOS GAT GEC TGC GTT ACD

$202^{\hat{i}}$ Lys Ile Ser ghe Asp Gly Val Arg Asn Glu ero leu Val Val gly Aso Ala Gys Val The

6480 TTG ANA AAT TTT GAR CMA ATG TTG GTG GCG TTT CGA MGC GAC CTT GTT GGT GTC ATT RGA

2037 Leu lys Asn f'he Glu glo Mer leu Val Ala fhe Arg ser A.sp leu Val Gly Vai Ile Arcy

6540 म̈GT GALG ATT GAT GGA ATT TT' TTT GCT CCT CAA AAT ACA GAG GGA GAC MAT CAC GLT GCA

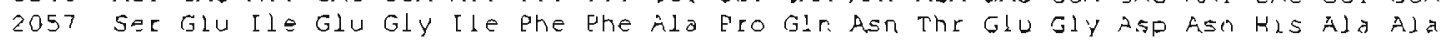

6600 TTG CCA AAA ACC ACT RGA GAT GAA ATG ACT TCT TCA GGT AAA MAG GGA AGT GRG GTT GTG

2077 Leu Pro Lys The Thr Arg Asp Glu Met Thr Ser Ser Gly Lys iys Gly sar Glu Val Val

6660 TGG TTC TCT CAA GCG TTG AGG GCG CAT CTT TCT AAT GCG TTT CGC RAG TAT TAT TGA CCT

2097 Gly Phe Ser Gln ala Leu Arg A.la his Leu Ser Asn Ala phe Arg Lys Tyr tye

6299

1976

6353

1996

6419

2016

5479

2036

6720 TTG GGT TGT GAG GTT GAT AAC TGG ATA TGG TGG GCA AAC GCC CGC CAC CCT TTC CCT ATA

6780 TAT ATT TAA TAT ATG TTT CAT GGG AGA GTT TAA AGA TGA TTT TTT GTT TGT TTG TTT TCC

6719

2114

6779

GB40 TAG GAT GTG TGA GAG GAA CGA GAG TGT GTG TAT GGC ATT GAA TTG CAT TTT ATT TTT RAT

5839

6900 GAT RAT TTT GTT ATT TTT TTC ACT TTT TCG TGC GCT AGT TTT AGA TAT GCA ATA GTG AAA

6960 CAA RAA CGT ATC TTT ATT RAT MAA TAT ATA TAT ATA TGG ATT TAG TTT TGT GCT TGG aGC

7020 CTO AGT GGG ATT AAA TTA TTG CCT TTT TTT TTT TTT TTT TTT TTT TGC AGA TTT GGT GCA

7080 TTG AEG GTG AGG GGA GGC ACA AGC GAT TAC GTC TTT ACG TITT TCT TCA ATT ATA TTA CTE

7140 GTG GGC GCG TTG CAA GGC TTT TTG SOT TथT TTT CAT TTT TTT CCT ECG TOT ETT TGT GCG

1200 ACA CGT TTA TAT CAG CTT TCT GCC CCC CGC TGG AGG GAA TTY GTG GCA TGC TCG TTT ATA

7320 AGC TGG GTC CGC GGT GCT GAC ATG GAG ATG TTT TTA CTG GGC AGC TCG TTG CTY CTT AGC 
Na Figura 12 está apresentada a seqüência nucleoridica (cerca de $7,4 \mathrm{~kb}$ ) da regiāo genômica que contém o gene B12. O passo de leitura e orientação da traduçāo foram deduzidos a partir das ORFs possíveis e da seqüência das repetições do clone B12 (Figura 1), originalmente isolado no vetor de expressão $\lambda g t l l$. As regiões das repetições seriadas, homólogas a B12, nāo foram inteiramente seqüenciadas. Somente a seqüência das primeiras repetiçōes de cada extremidade foi determinada, sendo que o número total de repetiçōes foi previamente estabelecido pelo mapa de restrição (ver item 3.17.2 e Figura 11). É possível verificar na Figura 12 que os fragmentos S3S4, S4S5 e S5B4 comparntham uma regiāo $5^{\prime}$ terminal comum. Além disso, os fragmentos H4S3, S3S4 e S4S5 apresentam a mesma regiăo $3^{\prime}$ terminal. Embora a orientaçào mútua dos fragmentos apresentada na Figura 12 respeite o passo de leitura das reperições homólogas a $\mathrm{B} 12$, não havia dados experimentais que a comprovassem. Como os fragmentos H4S3, S3S4, S4S5 e S5B4 foram obtidos por digestōes seguidas de subclonagens, é possivel que existisse um pequeno fragmento delimitado por sítios de Sall, intercalado entre esses fragmentos e nāo visivel em um gel de agarose. Para provar que as seqüências $3^{\prime}$ de um fragmento c 5 ' do seguinte estāo de fato localizadas contiguamente, e na orientação prevista pela provável codificaçāo protéica, realizou-se mais uma erapa de subclonagem e seqüenciamento.

Cada repetição seriada de 60 pb apresenta um sino de Sacll, ao passo que as seqüências terminais 3' e 5' nāo possuem nenhum sitio para essa enzima. A clivagem com SacIl de um clone maior, que contém os fragmentos H4S3, S3S4, S4S5 e S5E2 (ver Figura 8), liberaria então fragmentos de cerca de $0,6 \mathrm{~kb}$, que teriarn as seqüências 5 ' e $3^{\prime}$ terminais unidas. Daqui em diante esses fragmentos serão denominados genericamente de $5 c 5 c-0,6$. Escolheu-se o clone H4E2, derivado de BGE7 (ver Figura 8), para esse experimento. Embora esse clone apresente uma deleção artefarual na reggião entre os sirtios SS e E2, os demais fragmentos estão integralmente conservados. O DNA do clone foi digerido com Sacll e submetido a uma eletroforese em LMP agarose. O fragmento ScSc-0,6 foi purificado a partir do gel, subclonado $\mathrm{cm}$ pBluescript ${ }^{\otimes}$ e seqüenciado nas duas fitas. Os resultados (nāo mostrados) comprovaram que a orientaçāo prevista estava correta e que nāo há nenhuma sequiência interposta entre as regiōes $5^{\prime}$ e $3^{\prime}$ terminais. A regiāo compreendida entre os blocos de reperiçōes de $60 \mathrm{pb}$ se repete, por sua vez, três vezes ao longo do gene Bl2 (Figura 12) e o fragmento ScSc-0,6 representa somente um dos eventos. Contudo, nāo parece provável que os outros dois eventos sejam diferentes. Para corroborar essa idéia citase o experimento da digestăo de H4E2 com SacIl, no qual não se observaram bandas de ramanhos diferentes daqueles previstos (dados não mostrados).

Analisando a seqüência do gene B12, apresentada na Figura 12, foi possivel identificar um possivel códon de iniciaçăo ATG na posição 372 e um códon de terminação TGA na posição 6714. Na região "upstream" do códon de iniciação, e no mesmo passo de leitura, estão assinalados três códons de terminação nas posiçōes 252, 282 e 288 . A 


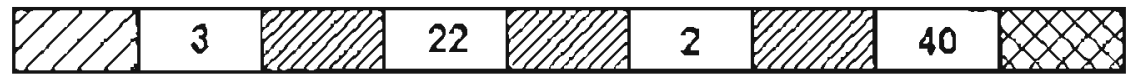

Z72 DOMINIO AMINO-TERMINAL - 36 AA

REPETIÇŌES SERJADAS DE 20 AA

EIIA RFPETIÇĂO DE 173 AA

DEQ DOMINIO CARBOXI-TERMINAL - 198 AA

Figura 13 - Esquema da estrutura da proteína B12, deduzido a partir do seqüenciamento de DNA dos fragmentos H4S3, S3S4, S4S5 e S5E2 do gene B12. Os quadros brancos representam as regiões que contém as repetições seriadas de 20 aminoácidos e seu respectivo número de unidades repetitivas. Também estão indicados os domínios amino-e carboxi-terminais e as repetições de 173 aminoácidos. O esquema não está apresentado em escala. 
dedução da seqüência protéica codificada pelo gene Bl2 mostra que a proteína é composta por 4 quatro domínios diferentes. Na Figura 13 pode-se ver que, alèm dos domínios amino e carboxi terminais de 36 e 198 aminoácidos, respectivamente, a proteína apresenta 3 repetiçōes de 173 aminoácídos, intercaladas por 4 blocos contendo um número variável de repetiçòes seriadas de 20 aminoácidos. Maiores detalhes das características dessa seqüência serão considerados no item 4.7.1 da Discussão.

\subsubsection{Análise computacional da seqüência de Bl2}

As seqüências protéicas dos 4 domínios da proteína Bl 2 foram enviadas para uma busca de homologia no GenBank, utilizando o programa BLAST do servidor do NCBI, conforme descrito nos itens 2.26.2.1 e 2.26.2.2. A análise individualizada de cada um dos dominios foi feita com o objetivo de se evirar que regiōes de repetiçōes seriadas, muito mais abundantes, pudessem influenciar tendenciosamente (inrroduzindo "bias") na busca de homologia. A proteína B12 é muito longa (2.114 aminoácidos) e é composta de domínios reperitivos que por sua vez também são constituidos de reperiçōes (ver Figura 13), o que dificulta a análise computacional da seqüência. Para levar em consideração as regiōes limitrofes entre os diferentes dominios e facilitar a análise da proteina B12, construiu-se uma quinta seqüência que será chamada de "Bl2 curta". Essa sequência apresenta respectivamente um dominio amino-terminal, um domínio com 4 repetições de 20 aa, uma reperição de 173 aa, um segundo domínio com 4 reperições de 20 aa e, finalmente, o domínio carboxi-terminal de 198 aa. Essa sequência apresenta a conveniência de ser curta e, por outro lado, contém toda a informação presente na proteina Bl2 completa. Como será visto adiante, a seqüência de B12 "curta" também foi utilizada para a análise da estrutura secundária.

A busca de homologia não revelou nenhuma proteina com homologia signifícativa a B12. O que se obteve foram pequenos blocos de alinhamento com várias proteinas, principalmente de citoesqueleto. O domínio amino-terminal apresentou um bloco de homologia com quinesina. A repetição de 173 aa apresentou pequenos blocos de homologia com proteinas ligantes de DNA e com a subunidade pesada da proteína triplet de neurofilamento (NF-H). A região de reperições seriadas demonstrou blocos cle homologia com proteínas ricas em prolina, incluindo a de neurofilamento e um antigeno de $85 \mathrm{kDa}$ de Babesia bovis. Finalmente, o dominio carboxi-terminal apresentou uma pequena homologia com filamina. A proteina de neurofilamento triplet $\mathrm{H}$ foi a única a apresentar blocos de homologia com mais de um domínio de B12. As regiões de homologia entre neurofilamento e os domínios das repetiçōes seriadas e da repetiçào de 173 aminoácidos estāo apresentadas na Figura 14. Essas homologias foram observadas em proteinas de neurofilamento de diferentes espécies, incluindo o homem, rato e camundongo. 


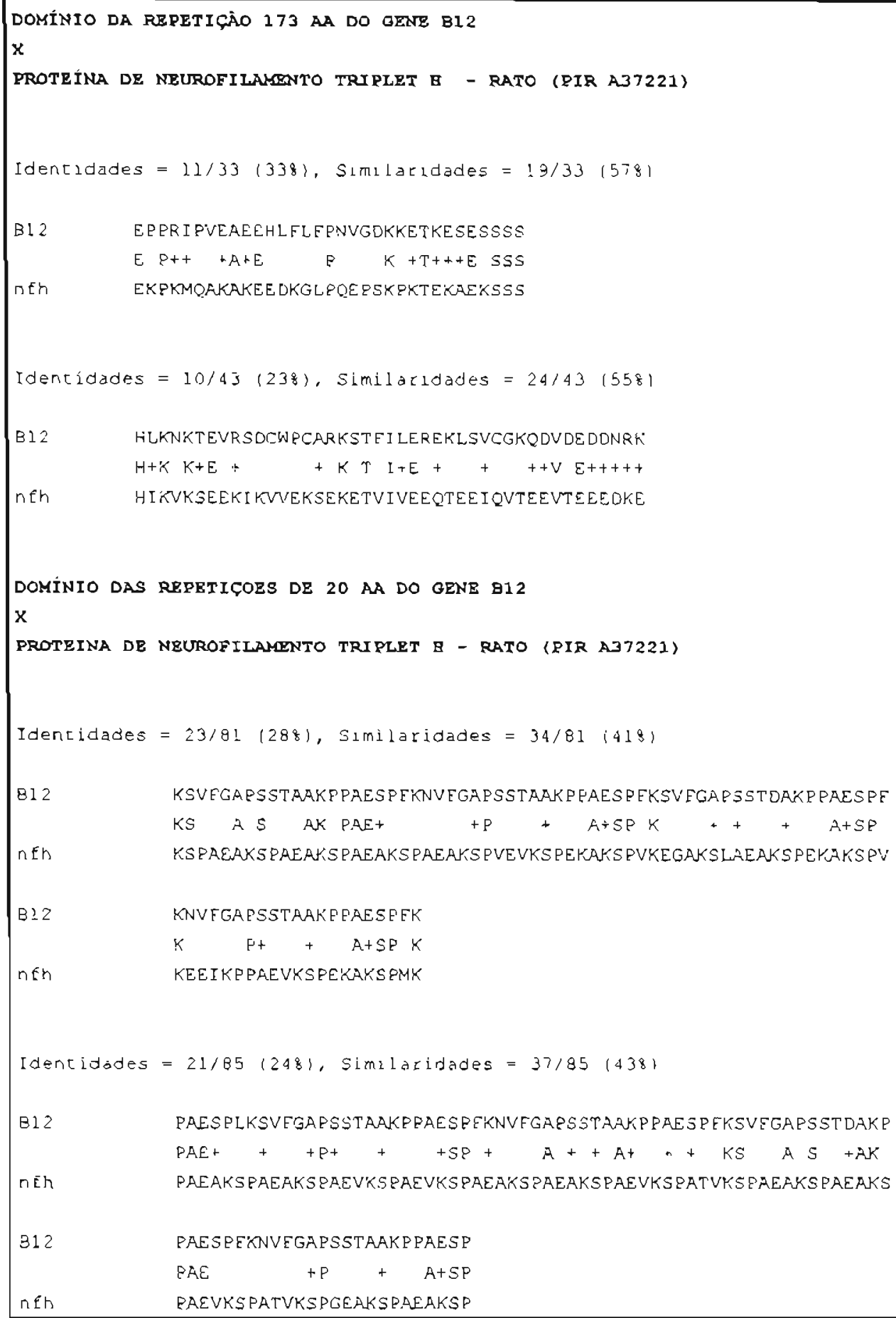

Figura 14 - Alinhamento de blocos de homologia entre os dominios das repetições menores (60 pb) e da repetição maior (173 aa) do gene $\mathrm{B} 12$ e a proteína de neurofilamento triplet $\mathrm{H}$ de rato (NF-H). As sequiências foram alinhadas com o programa BLAST (Altschul et al., 1990). As substituiçōes favorecidas evolutivamente (Dayhoff et al., 1983) estão assinaladas (+). 
A predição da estrutura de B12 foi feita com a seqüência "B12 curta" para facilitar a visualização. Utilizou-se o programa PEPTIDESTRUCTURE do pacote de análise GCG (Devereux et al, 1984). A hidrofilicidade da proteina foi calculada segundo o algoritmo de Kyte \& Doolirtle (1982) e a estrutura secundária por Chou-Fasman (1978). Na Figura 15 podem ser observados os esquemas em uma (A) e duas dimensões (B) dessas predições, visualizando-se as regiōes de $\alpha$-hélice, folha $\beta$-pregucada e dobras, bem como os possiveis sitios de glicosilação e a hidrofilicidade da proteína. Os respectivos domínios da proteina "B12 curta" estão assinalados na Figura 15A. A análise dos dados dessas prediçōes será feita no item 4.7.1 da Discussāo.

Página seguinte:

Figura 15 - (A) Predição da estrutura secundária da proteina "B12 curta" (ver texto) em esquema de uma dimensão. CF e KD referem-se, respectivamente, aos algoritmos de ChouFasman (1978) e Kyte \& Doolittle (1982). Estão assinalados os respectivos domínios da proteína B12, assimn como as regiões de $\alpha$-hélice, folha $\beta$-pregueada, dobras e sitios de glicosilação. (B) Predição apresentada em esquema de duas dimensões. Em função de a proteina B12 apresentar vários dominios repetidos, a análise foi feita com uma hipotética proteina contendo, além dos domínios amino e carboxi terminais, apenas um domínio da repetição maior e 2 domínios com 4 repetições menores. Dados calculados e plotados pelos programas PEPTIDESTRUCUTRE e PLOTSTRUCTURE, do pacote de análise de seqüências GCG (Devereux et al, 1984). 
A

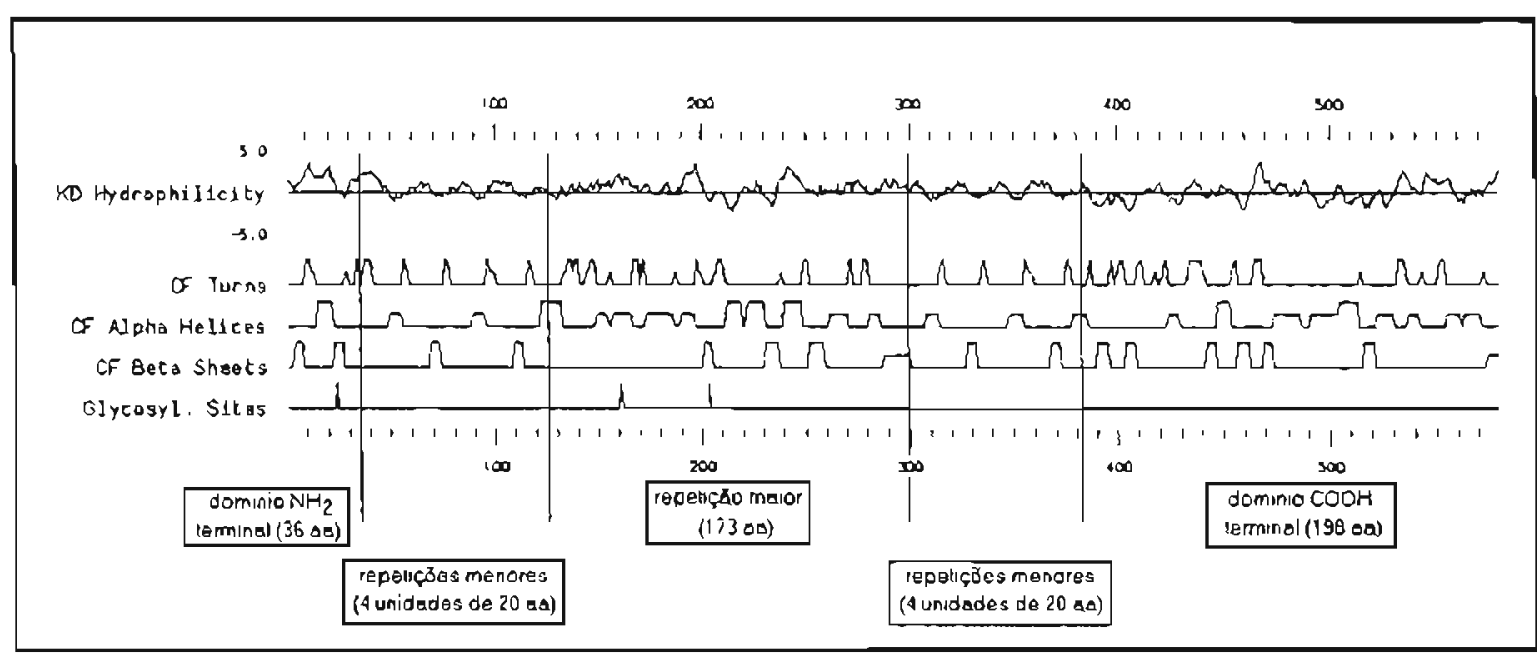

B

PLOTSTRUCTURE

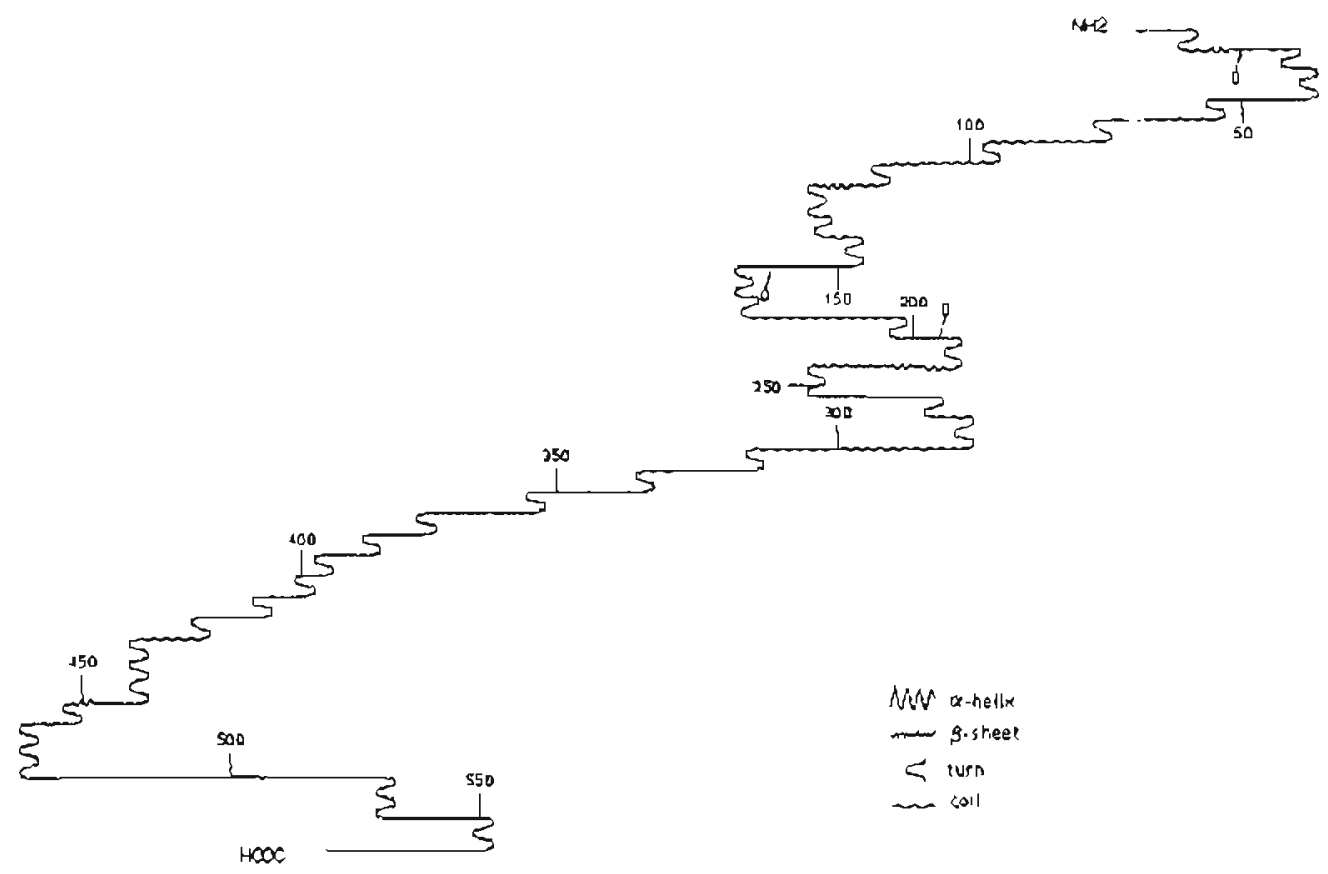


3.17.5. Seqüenciamento da região intergênica e 5' terminal do gene Bl3 (fragmento B4H5)

O fragmento B4H5, imediatamente contiguo à seqüência do gene B12 (ver Figura 12), é constituído pela região intergênica entre Bl2 e B13 e pela região 5' do gene B13 (consultar Figura 8). Para se obter subclones deletados nas duas orientaçōes, digeriu-se o DNA com as enzimas BamHI/BstXI e HindIII/KpnI, respectivamente. Em seguida as amostras foram submetidas à digestão unidirecional com Exonuclease III (vide item 2.25.1). Clones deletados nas duas orientaçōes, contendo sobreposiçōes, foram urilizados para o seqüenciamento do DNA. A junçāo física entre os fragmentos S5B4 e B4H5 foí confirmada pelo seqüenciamento do fragmento E2E3 (consultar Figura 8). A seqüência do fragmento B4H5, apresentada na Figura 14, contém em sua porçāo 5 ' terminal uma parte da região intergênica entre Bl2 e Bl3 e, na outra extremidade, o inicio do gene B13. Nas posições 553, $556,610,613$ e 829 estāo apresentados possíveis códons de iniciação do gene B13. Como a regiāo compreendida entre os códons 553 e 829 apresenta uma baixa probabilidade de codificação (ver discussāo no item 4.7.2), a traduçāo protéica está apresentada somente a partir do ATG da posiçāo 829. A direção da transcriçăo da ORF é a mesma do gene B12 (ver Figura 8), abrindo a possibilidade de os dois genes compartilharem um transcrito policistrônico (ver Discussāo - item 4.6).

\subsubsection{Análise computacional da seqüência do fragmento $\mathrm{B} 4 \mathrm{H} 5$}

A seqüência do fragmento B4H5, que codifica a extremidade amino-terminal do gene B13 foi submetida a uma busca de homologia com o programa BLAST do NCBI. Foi verificada uma alta homologia com o clone TcCA-2 (Buschiazzo et al, 1992), que é homólogo a B13. As duas seqüências foram entāo alinhadas com o programa BESTFIT, que permite estabelecer a regiāo de homologia mais significativa, incluindo lacunas. Conforme pode ser visto na Figura 17, o alinhamento de B4H5 e TcCa-2, apesar de conter 7 lacunas, apresenta uma identidade superior a 95,5\%.

\section{Página seguinte:}

Figura 16 - Seqüência nucleotídica da regiāo compreendida entre os sítios B4 e HS (consultar Figura 8), que inclui parte de região intergênica e a extremidade 5 ' terminal do gene B13. Os sítios de restrição B4, E3, N2 e H5 estão indicados em negrito, assim como os possíveis códons de iniciaçāo do gene B13 (posiçōes 553,556, 610,613 e 829). Um códon de rerminação (TAG - posiçāo 544) na região "upstream" do códon de iniciaçāo está sublinhado. A tradução protéica da ORF está apresentada a partir do ATG da posição 829 (ver texto). As flechas indicam prováveis sítios de "trans-splicing". 
$\operatorname{RamBI}(B 4)$

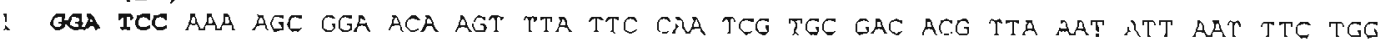

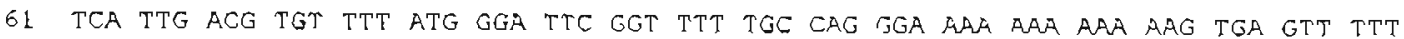

121 TTG ATC CCC ACC GTG GCT CAA CGA AGT GCT GTT TTT TTT TTT TTT TTT TCT GCT CTT ACE ECORI (E3)

181 AGT CGT AGT AAC TAC ACC TCA ATT GTG CAG CTC TGG TAA GCG TAC GAT GGA ATT CAG CAG

241 CAA GGA TAA CCT TAC TCC GCG GGC AGC CAT TAT AGA ATG GCT CCA ACA TCT GCC $C T T$ CCG

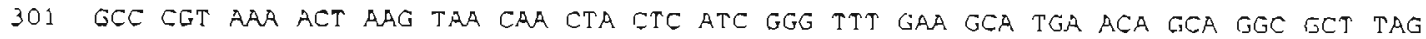

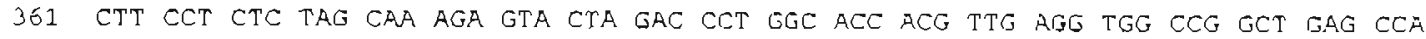

421 GGG ACG AAG TGC TOT CAT GTA AGG TCT GCT CAT ETC TGC GAG RTT TTT TTT TTT TTT TTT

480

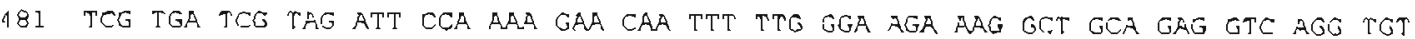

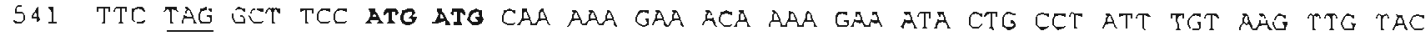
$N \in O I(N 2)$

601 TGC CGT GTT ATG ATG CTG GTT TGC GGA TAT GCG CCA TEG GCA CAA TTG AGG CGG TTA AAT

600

560

561 TGT AAT GTT TGS TTG GGG TAT AAT TTE TAC CTC TTT TTC TGC CTT TTT TTT TTT TTT mTT

721 TTT TTT TTT GTT TTT TTG TTT TTT GTT TTT ATT GAG CAC AGA ATT ATA TAT TTT MTA TMT

781 TTT GNT TTT CTG TTG TTG ATT GTT GTG GGG TCC CGT GAT TTA ATA AAT ATG GCC TTA CGT Mer Ala Leu Arg

O41 CCC ACG AAA CTA GAT GCG GTC TGT GAA GAG GTT CAT GGT GAA TTT SCA TCG TGT GGA CT

5 Pro thr lys leu Asp ala Val cys Glu glu Val his Gly giu phe Ala sec cys Gly leu

902 GCA AGT TTA CAG GAG CTC TGC CAG CAG GTG AGg CTG CTG CGC GCA AAT GTA CAA CGC CTT

25 Ala ser Leu Gln Glu leu Cys Gln Gln Val arg Leu leu Arg Ala Asn Va? Glu Rrg Leu

961 GCA TC, GAA CAA ATA CCG TCG CTC AGT CTG GAC ATA aCA GCG GTT CAG GAG GCT CAC CTG

45 Ala ser Glu Gln ile ero ser leu Ser leu asp lie thr Ala leu Gjn Glu pro yis leu

1021 CAC CTG CCG TTG CAT ACT RAT TTT CAT GTG GGC ATG CAG GAG ARG AAA CCG ACA CCA GGA

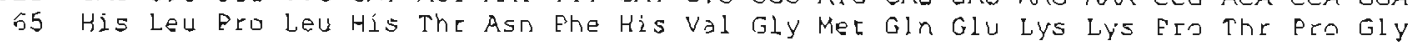

1081 AGT GTC ATC TTT GGT GCT GAG TCG CTC CTT TCA CAC TGC AAA AGG CTC ACT GCG GAC TGC

85 Ser Val Ile phe Gly Ala Glu Ser leu Leu Ser His Cys lys Arg Leu Thr Ala Asp Cys

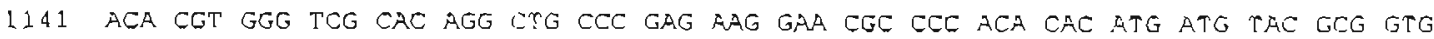

105 Thr Arg Gly ser His arg Leb fro giu lys Glu Arg pro thr his met mer tyr Ala Val

1201 GGT TAT ACC CCT AAT TAT CCC AAC AGA AAA ATG CCT TTG TAC AAT TCA RCC RAA TAC ACT

125 Gly Tyr The pro Asn tye Pro Asn Arg Lys Mel Pro Leu Tyr Asn Ser Thr Lys Tyr Thr

1261 GAA AGA GAA AAA ATA GAA GAA ARA MAA GAT ACA ACA GCG TAC GCT CCC AGC AAC CCO TCC

145 Glu Arg glu lys Ile Glu glu bys lys ksp Thr thr pro tyr Ala ero ser Aso ero ser

HindIII (日5)

1321 CAC GCC GAC GCC CAA AAA AGC TT

165 His Ala Asp Ala Gln Lys ser 


\section{Página seguinte:}

Figura 17 - Alinhamento entre as seqüencias nucleotidicas do fragmento B4H5 e do gene TcCA-2 de T. cruzi (Buschiazzo et al. 1992; código de acesso M92049). Os pontos representam identidades entre as bases comparadas. Os hifens representam regiōes de lacunas entre as seqüências alinhadas. Um suposto códon de iniciaçāo na posiçāo 829 do fragmento B4H5 está marcado em negrito. Alinhamento feito com o programa BESTFIT do pacote de programas GCG. Parâmetros e resultados do programa: Gap Weight 5.000; Average Match 1.000; Length Weight 0.300; Average Mismatch 0.000; Quality: 972.0; Length 3191; Ratio: 0.724; Gaps 7; Percent Similarity 95.591; Percent Identity: 95.591. 
B4H

$\mathrm{T} C \mathrm{CA}-2$

$84 H 5$

TCCA - 2

B4H5

TCCA-2

8445

TCCA-2

$84 \mathrm{HS}$

TCCA- 2

B 4 H5

TCCA-2

$\mathrm{B} 4 \mathrm{HS}$

TCCA- 2

$\mathrm{B} 4 \mathrm{HS}$

TCCA -?

$84 H_{5}$

TCCA -2

B 445

T̃CA- 2

24 45

TCSA-2

$84 \mathrm{HS}$

TCCA- 2

B4H5

TCCA- 2

B 4 H5

TCCA-2

$84 \mathrm{HS}$

$\mathrm{T} \subset \mathrm{CA}-2$

B4H5

T CCA-2

B445

TCCA- 2

B 4 in 5

T C $\mathrm{CA}-2$

B4 H5

$r=C A-2$

B4 $\mathrm{H} 5$

$\mathrm{T} C \mathrm{CA}-2$

B $4 \mathrm{H} 5$

$\mathrm{T} C \mathrm{CA}-2$

B4H5

T $\triangle C A-2$

B4H5

TCCA- 2
252 TTACTCCGCGGGCAGCCATTATAGAATGCTCCAACATCTGCCCTTCCGG 301

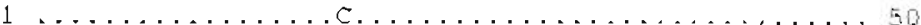

302 CCCGTAAAACTAAGTAACAACTACTCATCGgGTTTGAAGCATGAACAGCA 351

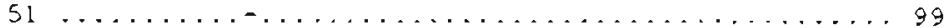

352 GGCGCTTAGCTTCCTCTCTAGCAAAGAGTACTAGACCCTGGCACCACGTT 401

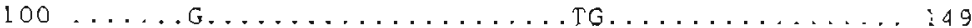

402 GAGGTGGCCGGCTGAGCCAGGG-ACGAAGTGCTGTCATGTRAGGTCTGCT 450

$150 \ldots \ldots \ldots \ldots \ldots \ldots \ldots \ldots \ldots \ldots \ldots \ldots . \ldots \ldots \ldots$

451 CATCTCTGCG-AGATTTTTTSTTTTTTTTTTT-----------CGTGAT 487

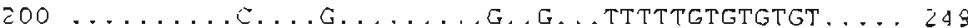

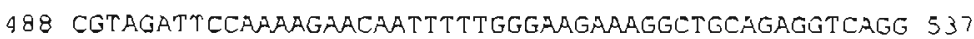

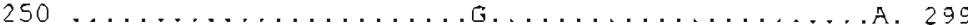

538 TGTTTCTAGGCTTCCATGATGCAAAAAGAAACAAAAGAGATACTGCCTAT 587

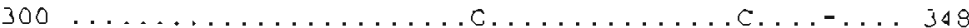

5BB TTGTAAGTTGTACTGCCGTGTTATGATGCTGGTTTGCCGATATGCGCCAT

$349 \ldots \ldots \ldots \ldots \ldots \ldots \ldots \ldots \ldots \ldots \ldots . \ldots \ldots . \ldots \ldots$

639 GGGCACRATTGAGgCCGTTAAATTGTAATGTTTOCTTGGGGTATAATTTC GB?

399 A. . . . . . . . . . . . . . . . . . . . . . . . 44

688 TACCTCTTTT TCTGOOTTTTTTTTTTTTTTTTTTTTTTTTTTGTTTTTTT 737

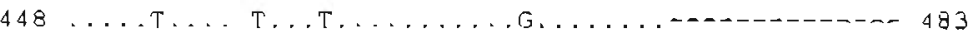

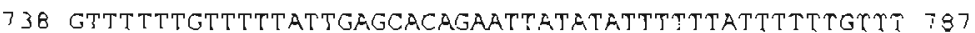

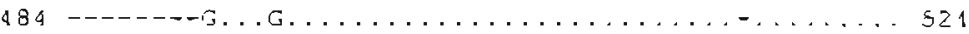

788 TTCTGTTGTTGATTGTGTGGGGTCCCGTGATTTAATRAATATGGCCTTA 83)

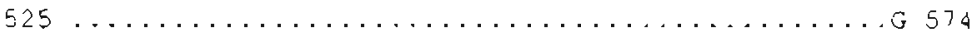

838 CGTCCCACGARACTAGATOCOOTCTGTGAAGAGGTTCATGGTGAATTTGC 887

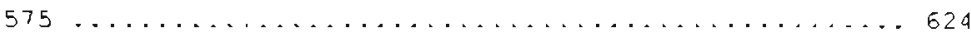

888 ATCGTGTGGACTTGCAAGTTTACAGGAGCTCTOCCAGCAGGTGAGGCTGC 93?

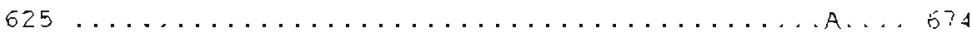

938 TGCGCGCAAATGTACAACGCCTTGCATCCGRACAAATACATTEGCTCAGT DET

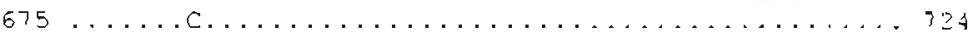

988 CTGGACATARCAGCGCTTCAGGAGCCTCACCTGCACCTGCCGTTGCATAC 103

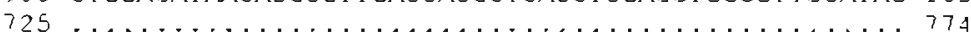

1038 TAATTTTCATGTGGGCATGCAGGAGAAGAAACCGACACCAGGAAGTGTCA : OA

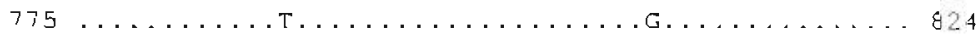

1088 TCTTTGGTGCTGAGRCGCiCCTTTCACACTGCAAAAGGCTCACTGCGGAC 113

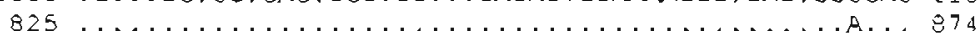

1138 TGCACACGTGGGTCGCACAGGETGCCCGAGAAGGAACGCCCCACACACAT 118

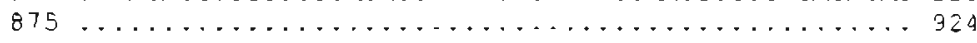

1188 gatgTACQCGgTgGgTTATACCCCTAATTATCCCAACAGAAAAATGCCTT 123

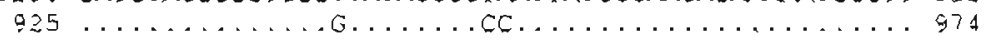

1236 TGTACAATTCAaCcaAatacactgaAagagaaAaAatagargaAaAaAaA 128

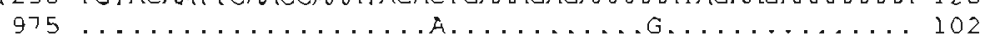

1289 GRTACAACACCGTACGCTECGAGCAACCCGTCCCACGECSACGCCCAAAA 133

$1025 \ldots \ldots \ldots$. . . A. . .................... 107

1338 AAGCTT 1343

$1075 \ldots . .1080$ 
3.18. Determinação do mapa de transcrição da regiāo de 32 kb

\subsubsection{Caracterização dos transcritos reconhecidos pelos clones genômicos}

Com a finalidade de determinar o mapa de transcrição da regiāo de $32 \mathrm{~kb}$, foi realizado um ensaio de Northern blot, utilizando como sondas os DNAs totais dos clones BGE 2, 7, 9 e 14. Conforme podemos ver na Figura 18 (consultar também a Figura 8), os clones BGE2 (canal a), BGE7 (canal b) e BGEI 4 (canal d) reconheceram os transcritos de 7,2 e $8,8 \mathrm{~kb}$ correspondentes a B 12 , bem como os transcritos de 4,2 e $3,5 \mathrm{~kb}$, homólogos a B13 (comparar com os resultados da Figura 4). O clone BGE9 (canal c) reconheceu os ranscritos de B12, mas nāo os de B13, confímando os dados do mapa de restrição. Um aspecto interessante é que os clones BGE7 (canal b) e BGE9 (canal c) também reconheceram um transcrito adicional, de cerca de $5,5 \mathrm{~kb}$. Essa banda de hibridização adicional pode ser devida à existência de um terceiro gene, contiguo a $\mathrm{Bl} 2$ e $\mathrm{Bl}$, e representado nos clones BGE7 e BGE9 (ver a seguir).

\subsubsection{Identificação de um terceiro gene denominado Bl l}

Visando localizar a região homóloga à banda de $5,5 \mathrm{~kb}$, hibridizou-se um Northern blot com sondas feitas a partir dos fragmentos S2S3 e ElHl (ver Figura 8). Nenhuma banda de hibridizaçāo foi visualizada (dados não mostrados). Concluiu-se que o únıco fragmento que poderia ter homologia com o RNA de 5,5 kb seria o SEl (ver fragmento marcado com asteriscos na Figura 8), delimitado pelo sítios Sall do "polylinker" do vetor $\lambda$ EMBL3, e o primeiro sítio de EcoRI da regiāo mapeada. Com o objetivo de verificar essa hipótese, o fragmento SEl, derivado do clone BGE7, foi subclonado em pBluescript ${ }^{\circ}$ inserto purificado foi utilizado como sonda em um ensaio de Northem blot. Como pode ser observado na Figura 18 (canal e), a sonda SEl hibridizou com a banda de $5,5 \mathrm{~kb}$. Esse resultado confirma a existência de um terceiro cistron, vizinho de Bl2 e Bl3, e que foi denominado Bl l (ver Figura 8). Além dessa banda, podem ser visualizadas bandas fracas de peso molecular maior, também reconhecidas pelas sondas dos clones BGE7 (canal b) e BGE9 (canal c), as quais contém o próprio fragmenro SEl (ver Figura 8). Essas bandas podem representar transcritos com certo grau de homologia a Bl l ou ainda espécies policistrônicas presentes em baixa concentraçāo.

A anàise da Figura 18 indica que o padrão de hibridização da banda de $5,5 \mathrm{~kb}$ é muito mais intenso do que o dos transcritos de B12 e B13. A tira do canal e. hibridizada com o fragmento SE1 foi, inclusive, exposta por muito menos tempo, a fim de permitir a 


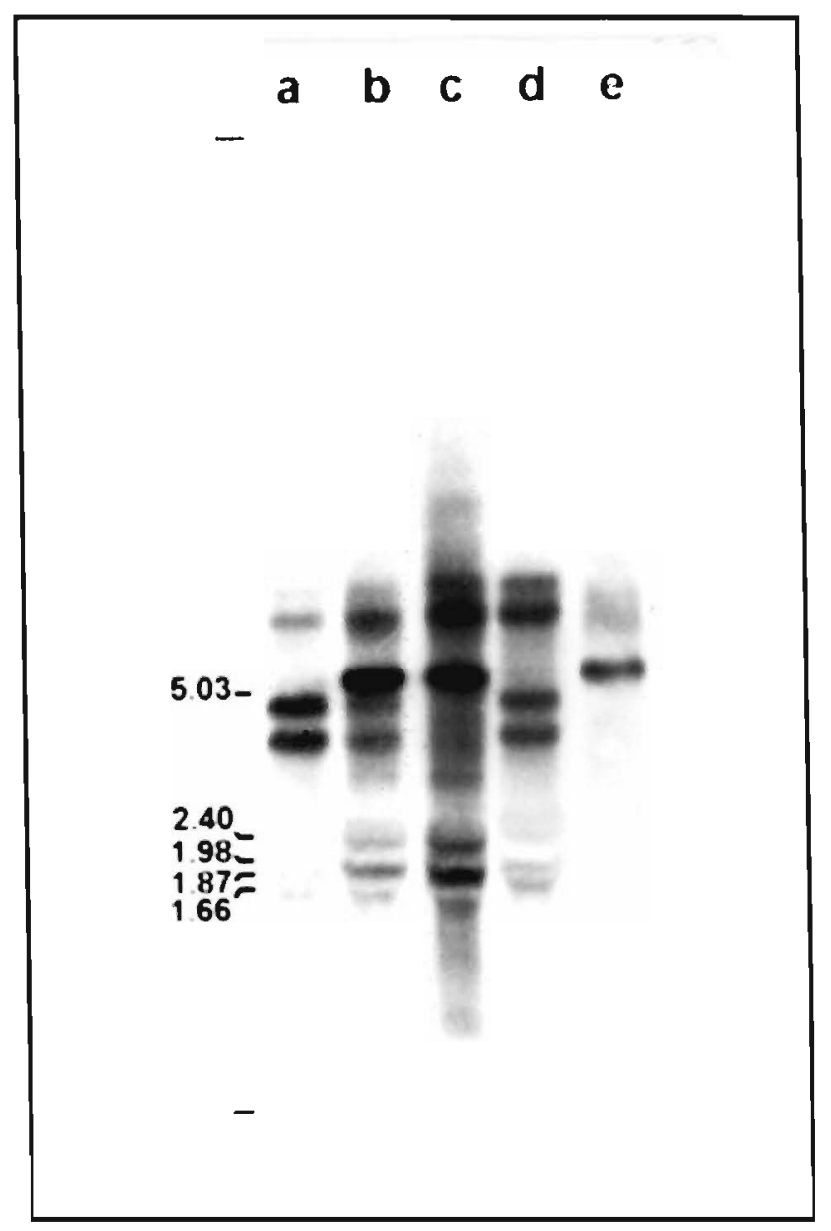

Figura 18 - Northern biot de RNA total de epimastigotas em gel de agarose $0,7 \%$, hibridizado com sondas dos clones BGE 2 (a), BGE 7 (b), BGE 9 (c), BGE 14 (d) e SEl (e). Consultar Figura 8 para a identificação das respectivas regiões abrangidas por cada sonda. A exposição da tira de nylon hibridizada com a sonda SEl foi mais curta para permitir a composição da figura. Marcadores de peso molecular de RNA ribossomal (rRNA de T. cruzi e de células LLC-MK2), em quilobases, estão indicados. 
composiçāo da foto. Esse resultado sugere que a concentração do transcrito de Bl l é muito mais elevada do que a dos transcritos dos genes Bl 2 e Bl3. A banda de $5,5 \mathrm{~kb}$ também foi reconhecida pela sonda SEl em Northern blot com mRNA poli $(A)^{+}$, apesar que com menor intensidade (dados não mostrados). Não foi analisado o padrão de hibridização de RNA de formas nipomastigoras com a sonda SEL.

\subsection{Caracterizaçāo do gene Bl l}

\subsubsection{Estudo do arranjo genômico do clone SEl}

Uma vez demonstrado que o fragmento SEl hibridiza com um transcrito de $5,5 \mathrm{~kb}$, decidiu-se investigar o arranjo genōmico do respectivo gene. Para essa finalidade procedeuse a um ensaio de Southern blot, conforme descrito (itens 2.23.1 e 2.23.2). O padrão de hibridizacão da sonda SEl com DNA de T, cruzi, digerido com várias enzimas de restricão, evidencia um grande número de bandas em algumas digestōes, sendo compativel com o de um gene de múltiplas cópias (Figura 19). Na digestāo com Sacll verifica-se uma banda forte de hibridizaçāo, de cerca de l,0 kb, e a ausência toral de bandas de maior peso. Isso sugere que as cópias do gene B 11 não devem ser polimórficas para os sítios de SaclI.

\subsubsection{Seqüenciamento do fragmento SEl}

Visando obter a sequêencia nucleotidica completa do clone SEl, procedeu-se à digestão do DNA do clone pBluescript ${ }^{\ominus}$-SEl com as enzimas Xhol e KpnI e, posteriormente, à reação de digestão unidirecional com Exonuclease III, conforme descrito no item 2.25.1. Para o seqüenciamento da fita oposta foi empregada a dupla de enzimas BamHI e SacI. A sequêencia nucleoridica final foi obtida a partir da confrontação dos dados de sequiencia das duas fitas. Conforme pode ser visto na Figura 20, o inserto SEI apresenta 759 pb e um passo de lcitura aberto na orientação EcoRI - Sall, ao longo de todo o inserto. A seqüência protéica, traduzida a partir da ORF, tambèm está apresentada na Figura 20. A direçāo da transcriçāo dessa hipotética ORF seria portanto oposta à dos genes Bl 2 e Bl3 (ver Figura 8).

As seqüencias nucleotidica e protéica do fragmento SEl foram submetidas à busca de homologia no programa BLAST do NCBL. A seqüência protéica apresentou homologia com a proreína da ORF-1 de TRS-1, um elemento com caracteristicas de retrorransposon, isolado de $T$. brucei (Murphy et al, 1987). Quando as seqüencias das duas proteínas foram alinhadas pelo programa BESTFIT (Figura 21) observou-se uma homologia de $48 \%$ e uma identidade de 30\%. Utilizando o mesmo programa para o alinhamento das seqüencias nucleotídicas, observou-se uma identidade de $43 \%$ (Figura 22). Esses dados serão melhor discutidos adiante (item 4.8 ). 


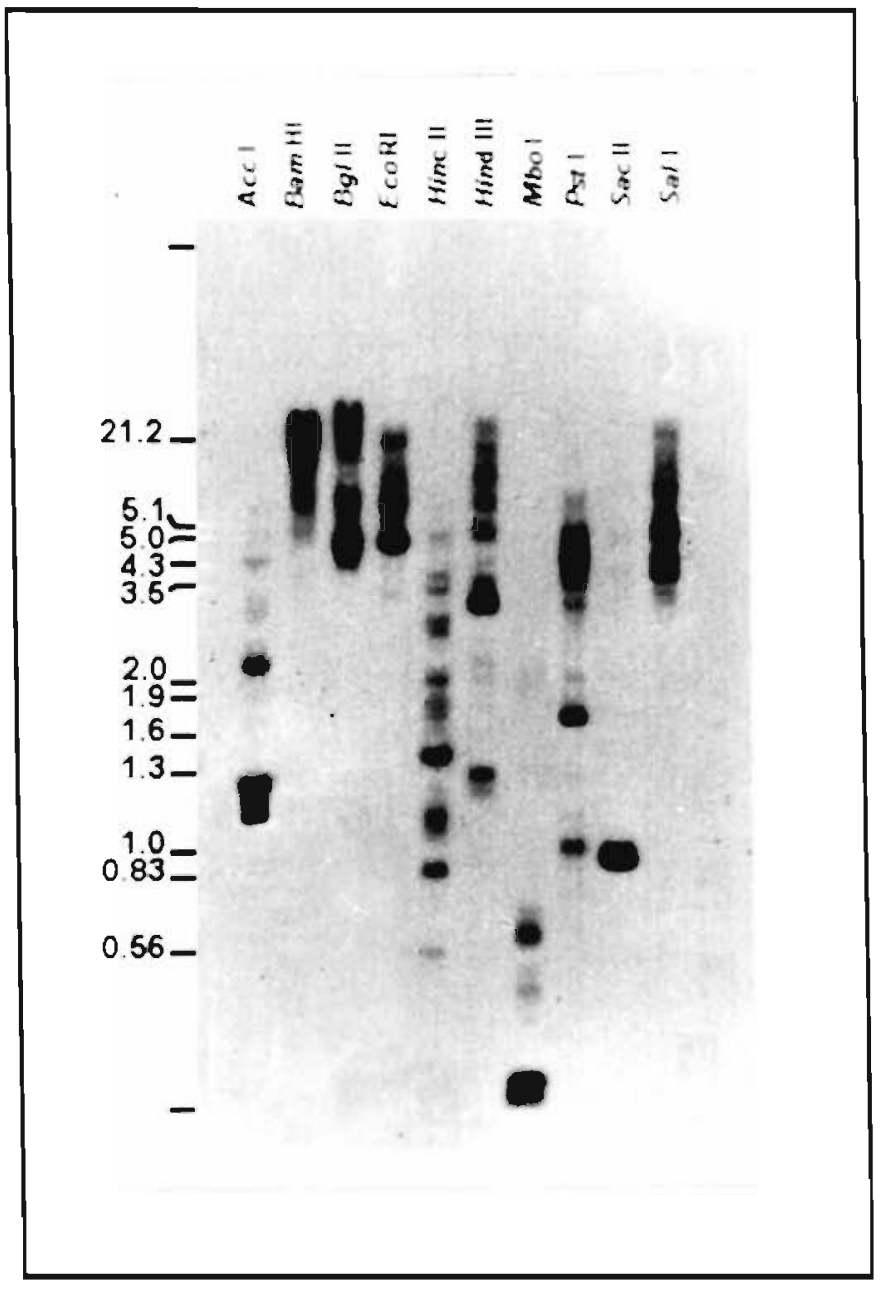

Figura 19 - Southern blot com DNA de formas epimastigotas de T. cruzi (cepa Y), digerido com enzimas de restrição e hibridizado com a sonda SEl. Marcadores de peso molecular, em quilobases, estão indicados. 


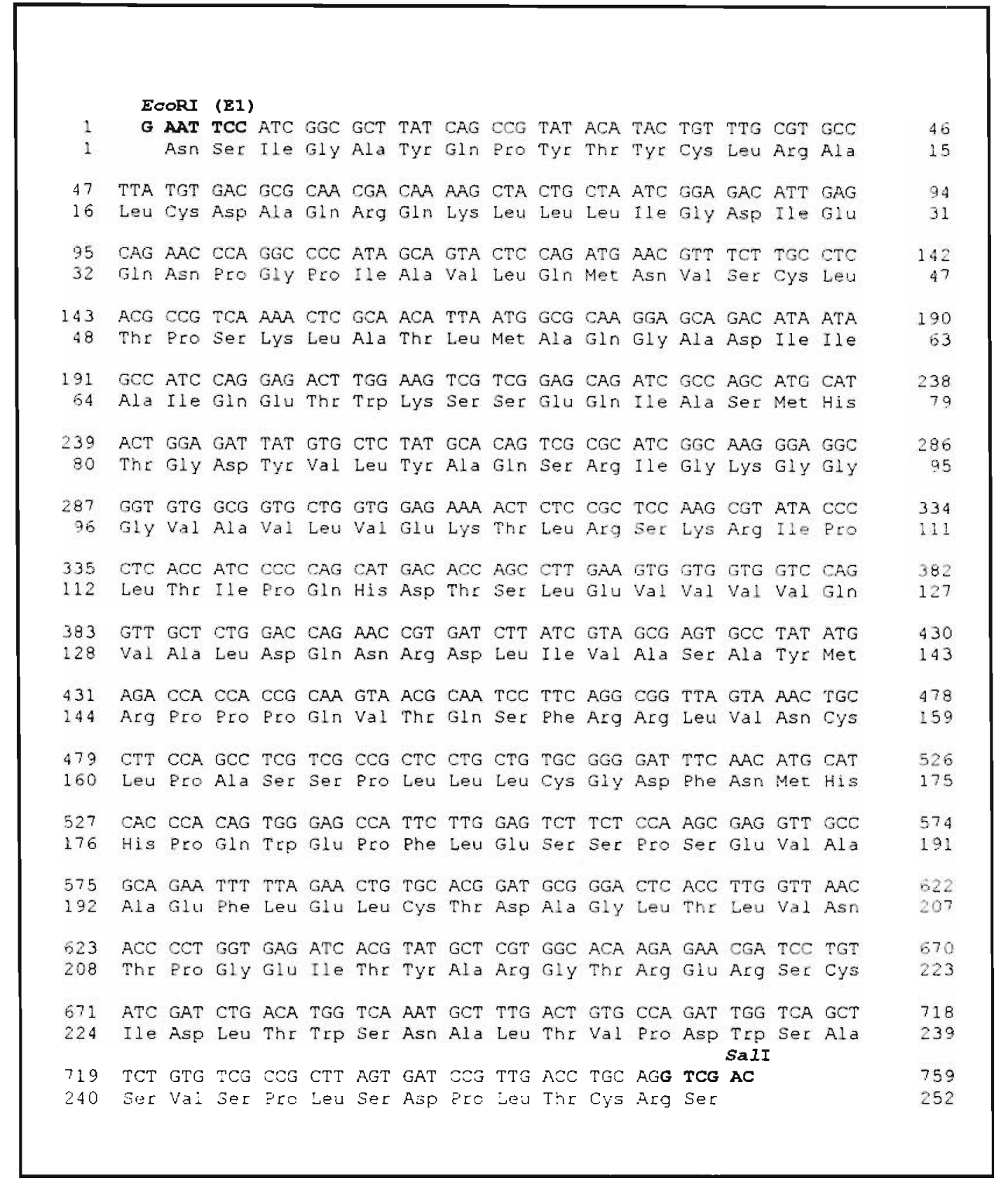

Figura 20 - Seqüência nucleotídica completa do fragmento SE1 na orientação EcoRI $\rightarrow$ Sall. Os sítios de restrição EcoRI e SalI, que delimitam esse inserto, estāo assinalados em negrito. A traduçāo da seqüência protéica está apresentada. 


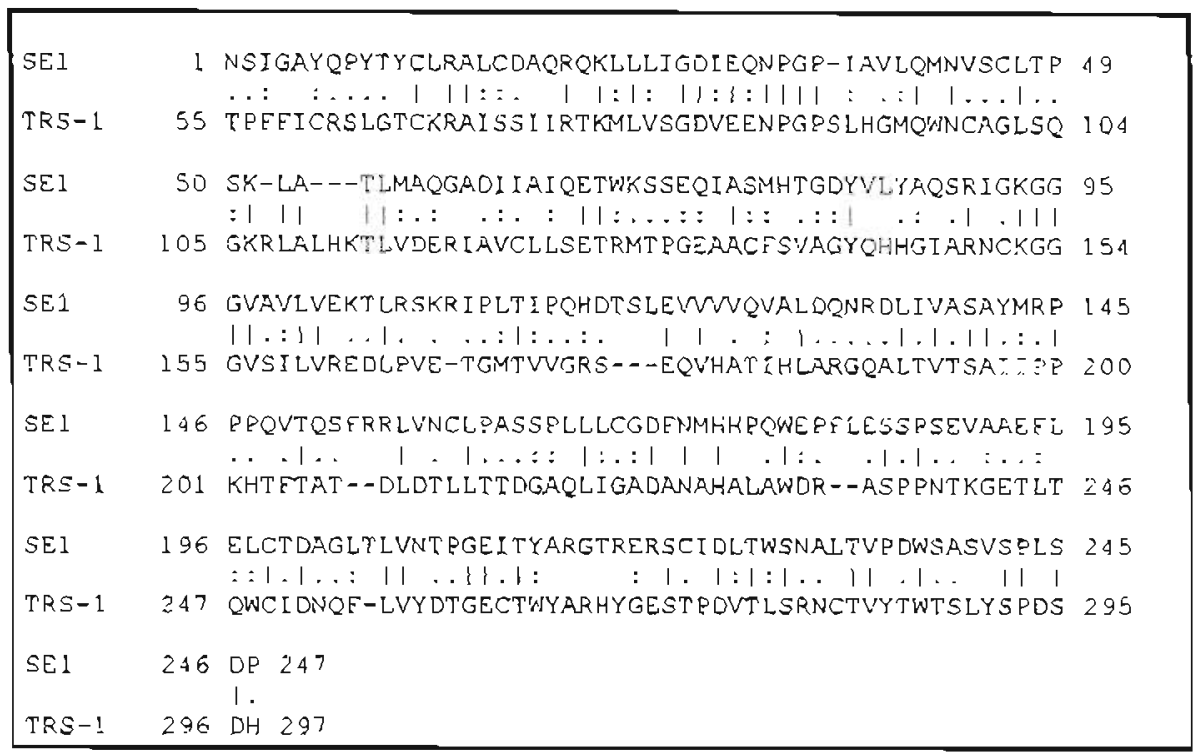

Figura 21 - Alinhamento entre as seqüencias protéicas do fragmento SEl e da ORF-1 de TRS-1 de $T$. brucei. Os hifens representam regiões de lacunas entre as seqüências alinhadas. Os símbolos entre as sequiencias representam residuos idênticos ( I ), resíduos pertencentes ao mesmo grupo (:) com substituições favorecidas evolutivamente (Dayhoff et al., 1983), e outras substituições ( . ). Alinhamento feito com o programa BESTFIT, do pacote de análise de seqüências GCG. Parâmerros e resultados do programa: Gap Weight 3.000; Average Match 0.540; Length Weight 0.100; Average Mismatch -0.396; Quality: 124.6; Length 252; Ratio: 0.513; Gaps 8; Percent Simílarity 47.899; Percent Identity: 29.832. 


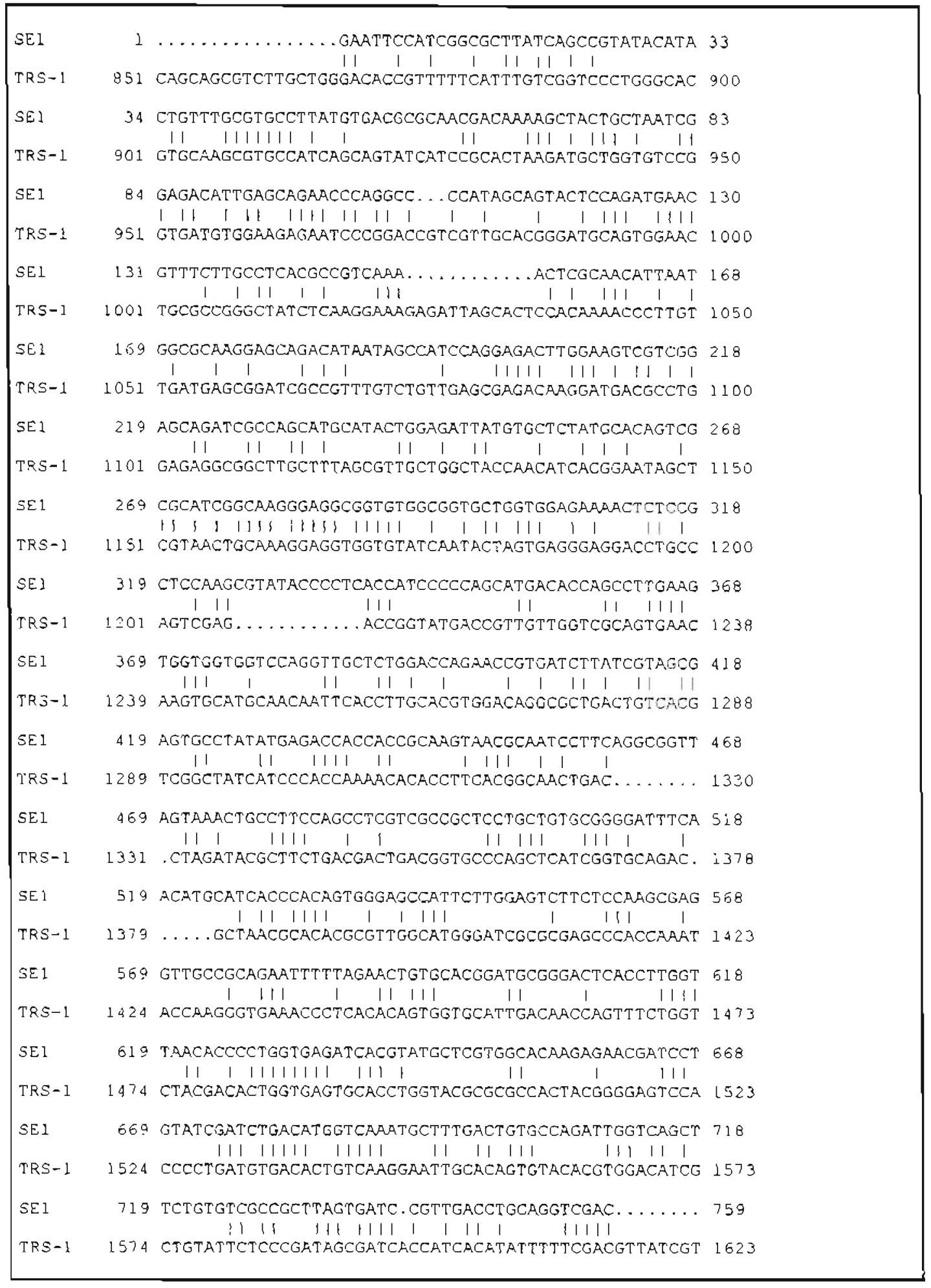

Figura 22 - Alinhamento das seqüências nucleotidicas do fragmento SE1 com a de TRS. 1 de $T$. brucei. Os pontos representam regiōes de lacunas entre as seqüencias alinhadas. Alinhamento feiro com o programa GAP, do pacote de análise de sequiências GCG. Parâmetros e resultados do programa: Gap Weight 5.000; Average Match 1.000; Length Weight 0.300; Average Mismatch 0.000; Quality; 271.1; Length 6853; Ratio: 0.357; Gaps 6; Percent Similarity 42.896; Percent Identity: 42.896. 
A proteína codificada pelo fragmento SEl foi analisada quanto à sua possivel estrutura secundária, utilizando o programa PEPTIDESTRUCTURE. As prediçōes de hidrofilicidade e de estrurura secundária foram feitas a partir dos algoritmos de Kyte \& Doolittle (1982) e Chou \& Fasman (1978), respectivamente. Conforme pode ser visualizado na Figura 23, as regiòes de estrutura definida sāo muito curtas e a proteina alterna pequenas regiōes de alta e baixa hidrofilicidade.

\subsection{Estudo do arranjo cromossômico dos genes Bl l, Bl2 e Bl3}

Os resultados apresentados até o momento demonstram que uma região de $32 \mathrm{~kb}$ do genoma de $T$. cruzi foi mapeada (Figura 8) e contém 3 cistrons denominados B1 1, Bl 2 e $\mathrm{B} 13$, respectivamente. Os genes $\mathrm{B} 12$ e $\mathrm{Bl} 3$ apresentam um padrão de hibridização compativel com uma única cópia por genoma haplóide (Figura 2), enquanto Bll parece ser um gene de múltiplas cópias (Figura 16). Com o objetivo de verificar a distribuição cromossômica desses genes, realizou-se um ensaio de Southem blot a partir de um gel de separação de cromossomos de $T$. cruzi. Amostras de DNA de formas epimastigotas das cepas CL, Y e G foram preparadas e separadas em eletroforese de campo pulsado por Maria Isabel Cano (Escola Paulista de Medicina), utilizando o sistema Gene Navigator (ver item 2.27). O gel foi transferido para um filtro de nylon e hibridizado com sondas feitas a partir do fragmento SEl (representando o gene B11 - ver Figura 8) e dos clones B12 e B13.

Conforme pode ser visto na Figura 24, as sondas Bl2 e Bl3 hibridizaram com um único cromossomo de $1,26 \mathrm{Mb}$ na cepa $\mathrm{CL}, 1,41 \mathrm{Mb}$ na cepa $Y$ e $0,98 \mathrm{Mb}$ na cepa $\mathrm{G}$. Esse resultado confirma a proximidade física dos genes Bl2 e B13. A sonda SEl hibridizou com praticamente todos os cromossomos, confirmando que o gene Bll está presente em múltiplas cópias distribuídas em cromossomos, que variam de 3,1 a 0,58 $\mathrm{Mb}$ na cepa $\mathrm{CL}_{\text {; }}$ 2,4 a 0,58 Mb na cepa Y e 3,8 a 0,51 Mb na cepa G. Conclui-se ainda que os genes Bl 1, B 12 e B13 estão presentes em diferentes cepas de $T$. cruzi. 


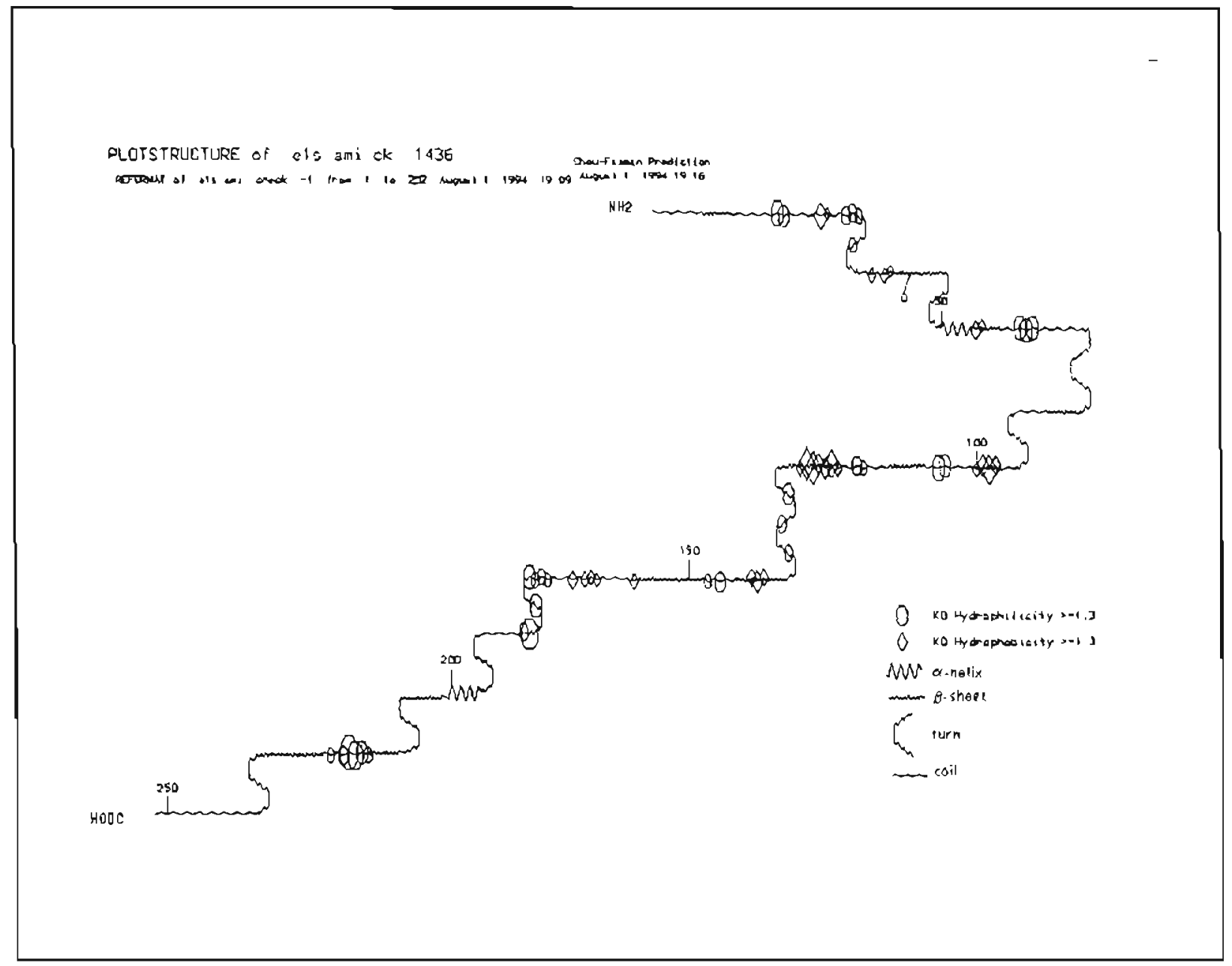

Figura 23 - Esquema em duas dimensões da prediçāo da estrutura secundária da sequuência protéica codificada pelo fragmento SEl, segundo o algoritmo de Chou-Fasman (1978). Estāo assinalados no esquema as regióes de $\alpha$-hélice, folha $\beta$-pregueada, dobras, molas e os locais de maior hidrofilicidade e hidrofobicidade, conforme o método de Kyte \& Doolittle (1982). Dados calculados pelo programa PEPTIDESTRUCTURE e plotados pelo PLOTSTRUCTURE do pacote de análise de seqüências GCG (Devereux et al, 1984). 


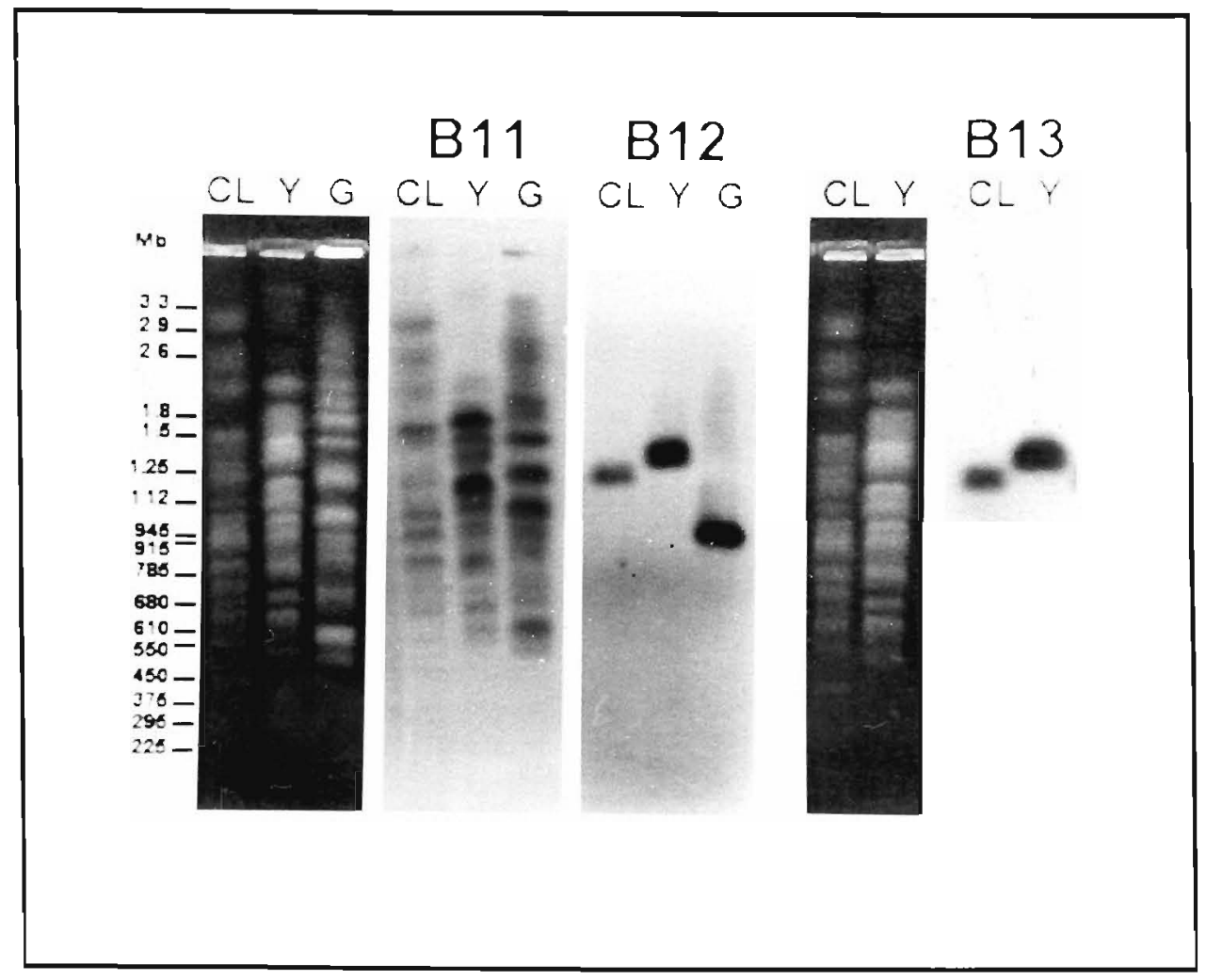

Figura 24 - Cromossomos de formas epimastigotas de $T$. cruzi, das cepas $C L$, I e $G$, separados por eletroforese de campo pulsado (Gene Navigator System). O primeiro e o quarto painéis representam o gel corado com brometo de etidio. O gel foi transferido para um filtro de nylon e hibridizado com as sondas B1 I (fragmento SE1), B12 e B13. Marcadores de peso molecular, em megabases, estão indicados. 


\section{DISCUSSÃO}

No presente trabalho descrevemos o isolamento e caracterização de dois genes que codificam antígenos de $T$. cruzi. Esses genes foram inicialmente identificados a partir de uma biblioteca de expressão construida em $\lambda$ gt1l e triada com um soro policlonal de coelho contra a forma tripomastigota. A seguir, os genes completos foram isolados a partir de uma biblioteca genômica em $\lambda E M B L 3$ e caracterizados quanto a seus produtos de transcrição e de tradução no parasita. Verificou-se que as proteínas recombinantes podem ser utilizadas no diagnóstico sorológico da doença de Chagas. Além disto, o arranjo genômico dos genes foi analisado em Southern blots de DNA digerido com enzimas de restrição e de cromossomos do parasitas separados por eletroforese de campo pulsado. Finalmente a seqüência nucleotidica completa de um desses genes foi determinada. Nesse item discutiremos os resultados e conclusões obtidas no trabalho, comparando-os com dados da literatura.

\subsection{Um novo método de absorção de soros}

Na literatura, existem várias técnicas de absorção de soros destinados à varredura de bibliotecas de expressão, entretanto cada uma delas apresenta algumas desvantagens. 0 método mais comumente empregado consiste em se plaquear fagos não recombinantes em uma densidade de placas suficiente para a obtenção de lise confluente. Filtros de nitrocelulose são então colocados sobre o tapete bacteriano lisado e os antígenos são adsorvidos. Esses filtros são bloqueados e incubados com o soro a ser absorvido, mimetizando uma varredura de clones (Ozaki et al., 1986; Snyder et al., 1987). Como a massa de antígeno imobilizado é pequena, são necessários muitos ciclos de incubação. Há várias desvantagens nesse método. Em primeiro lugar utiliza-se uma quantidade muito grande de filtros, o que o torna bastante dispendioso. A despeito de os filtros serem bloqueados a cada ciclo, quanto maior for o número de ciclos, maior será também a perda de anticorpos imobilizados na nitrocelulose. Além disso, a excessiva manipulação do soro ao longo dos ciclos pode levar a consideráveis perdas de seu título. Um outro método envolve a obtenção de um lisado bacteriano, seu acoplamento em resina de agarose ativada e posterior remoção dos anticorpos por cromatografia de afinidade (Sambrook et al., 1989). Além de envolver a utilização de uma resina cara, é bastante trabalhoso, pois exige etapas de cultivo, lise, acoplamento e cromatografia. Uma variação desse método é a diluição do soro no próprio lisado bacteriano. Esse método é simples e barato, porém implica na adição irreversível de componentes exógenos ao soro, entre os quais podem estar proteases bacterianas, que podem reduzir a vida útil dos anticorpos. Além disso, a adição do lisado 
não remove efetivamente os anticorpos anti-E. coli, mas simplesmente funciona como um competidor pela sua ligaçāo.

O método proposto nesse trabalho (ver irem 2.10.1) tem sido utilizado há muitos anos para a absorção de anticorpos de soros destinados à sorotipagem de bactérias (Ørskov \& Ørskov, 1984). Entretanto, seu emprego em soros destinados à utilizaçāo em técnicas de biologia molecular é inédita na literaura. A utilizaçâo de bactérias integras formolizadas garante a absorçāo de anticorpos contra antígenos de superfície que são, geralmente, os mais imunodominantes. A autoclavação das bactérias visa a exposição de antígenos mais internos. Como o processo de absorção somente utiliza a fraçāo insolúvel, não há a adição de componentes exógenos ao soro. Em cada etapa de centrifugação hả a efetiva remoção dos anticorpos anti-E. coli. Além dísso, nāo há risco de contaminação bacteriana, pois nas duas aliquotas utilizadas as bactérias já estão mortas. Testes de cultivo, realizados com a fração formolizada, comprovaram a total esterilidade da preparação. Finalmente, o processo é extremamente barato, fácil de ser executado e bastante rápido. O soro é relativamente pouco manipulado e o grau de absorção pode ser controlado pelo número de ciclos de absorção.

\subsection{Diagnóstico sorológico da doença de Chagas}

A partir da metade da década de 80 alguns grupos clonaram e expressaram antigenos de $T$. cruzi em $E$. coli. Vários desses antigenos demonstraram reatividade frente a soros de pacientes chagásicos em fase aguda e crônica (cf. Frasch et al., 1991). Esses resultados levaram à idéia de que antigenos recombinantes de $T$. cruzi poderiam constituir uma altemativa aos métodos atuais de diagnóstico sorológico da doença de Chagas (cf. Frasch \& Reyes, 1990). Pensando nessa possibilidade, decidiu-se investigar o grau de eficiência dos antígenos B12 e B13 na discriminaçāo de soros de pacientes chagásicos.

Os resultados apresentados nesse trabalho demonstram que a proteina recombinante $\mathrm{B} 13$ é potencialmente aplicável no diagnóstico sorológico da doença de Chagas. O desempenho de Bl3, tanto em termos de sensibilidade como de especificidade, é superior a de B12. No estudo multicêntrico promovido pela OMS, o antigeno B1 2 apresentou um índice $x$ de 0,50, enquanto que B13 obteve o segundo melhor desempenho em relação a 21 antígenos recombinantes provenientes de 9 laboratórios diferentes (Moncayo \& Luquetti, 1990). Entre 50 soros testados, compreendendo soros de indivíduos normais, pacientes chagásicos e portadores de outras parasitoses, o antígeno B13 não detectou apenas um indivíduo chagásico, discriminando todos os soros negativos (Zingales et al, 1990). 0 antígeno 2 de Ibañez et al. (1987), homólogo a B13, também participou do esrudo, obtendo um indice $x$ de 0,84 , contra 0,96 de BI3. Esse resultado indica que a metodologia empregada tanto na purificaçāo da proteína, como no teste sorológico é muito importante 
para o diagnóstico correto. Quando os testes foram estendidos para um painel de 128 soros, B13 apresentou uma sensibilidade e especificidade de $97 \%$ e o indice $k$ baixou para 0,94, sendo ainda assim bastante satisfatório para seu emprego no sorodiagnóstico da doença de Chagas. Com relação a B12, testado frente ao mesmo painel de soros, observouse sensibilidade de $83 \%$ e especificidade de $78 \%$, com um indice $\kappa$ de 0,61 Uma explicação para um desempento menos eficiente de Bl2 em relaçāo a Bl3 poderia ser a menor representatividade do peptídio de Bl2 em relação ao tamanho total da proteína de fusāo. Enquanto B13 representa cerca de 16\% da proteina de fusão, B12 constitui apenas 1 1\%. Em função da conformação conferida pela $\beta$-galactosidase, os epitopos de B12 poderiam estar crípticos, diminuindo sua reatividade perante os soros. Outra alternativa é a de que, de fato, o antigeno do parasita correspondente a B12 é menos antigênico que B13 ou menos expresso em distintas cepas de T. cruzi.

Com o objetivo de verificar a primeira hipótese e obter um antigeno recombinante mais eficiente, foi construido o clone pGEX-S3S4. O fragmento S3S4 (consulte Figuras 8, 11 e 12) codifica 22 repetições seriadas de 20 aminoácidos, ao passo que a proteina de fusào $\beta$-gal-Bl 2 contem somente 6 repetiçōes. O vetor pGEX expressou a proteína recombinante em grandes quantidades (até cerca de $25 \mathrm{mg} / \mathrm{L}$ ) na hospedeira DH5 $\alpha$. Entretanto, conforme foi mostrado (comparar canais $d$ e $e$ da Figura 10), cerca da metade da proteina de fusão apresentou-se em corpúsculos de inclusão. A fraçāo solúvel da proteína apresentou uma baixa afinidade pela resina GSH-agarose, reduzindo a eficiência desse método de purificação. O dominio representado pelo fragmento S3S4 deve, possivelmente, levar a uma conformação inadequada para a ligação da proteína de fusāo à GSH. A precipitação seletiva da proteína pela adição de SDS à solução passou a ser empregada devido à sua facilidade de execução. Não está clara a ação do SDS no processo. O SDS, sendo um detergente de carga negativa, poderia neutralizar as cargas positivas presentes especialmente nas repetições seriadas, onde hả a ocorrência de duas lisinas contra um ácido glutâmico, conferindo uma carga líquida positiva à proteína. Ao neutralizar essas cargas, o detergente poderia reduzir a repulsāo intermolecular e, assim, permitir a agregação das moléculas e sua insolubilização. É importante lembrar, no entanto, que esta abordagem recupera apenas metade da proteína, já que o restante permanece na fração insolúvel do lisado. Por outro lado, a proteina presente nos corpúsculos de inclusāo nāo pode ser utilizada diretamente, uma vez que contém uma grande massa de proteinas contaminantes (consulte Figura 10, canal $d$ ).

A proteina de fusão purificada GST-S3S4, seja por afinidade ou por precipitação seletiva, apresentou baixa solubilidade. Isso se refletia especialmente na estocagem onde, após congelamento, a proteína precipitava totalmente. A ressolubilização somente foi possível em tampão trietanolamina com um pH superior a 10. Grieco et al (1992) relataram um método semelhante para ressolubilizar proteinas fundidas à GST presentes em 
corpúsculos de inclusão. Desta forma, os corpúsculos foram ressuspensos em uma solução contendo $1,5 \%$ Sarkosyl $^{\otimes} / 25 \mathrm{mM}$ trietanolamina/l mM EDTA, pH 8,0. A proteina ressolubilizada foi adicionada de Triton ${ }^{\circledR}-100$ e, mesmo após centrifugação, se manteve no sobrenadante. Segundo os autores, o Sarkosyl ${ }^{\circledR}$ romperia as interacões responsáveis pela formação de coagregados insolúveis de proteinas de fusão e componentes extemos da membrana da bactéria. Este método nāo foi testado por nós na solubilização da proteína GST-S3S4 a partir da fração insolúvel.

Um segundo problema na manipulação de GST-S3S4 se refere à estabilidade da proteína. Mesmo quando estocada a $-20^{\circ} \mathrm{C}$, a proteína apresenta elevado grau de degradação após alguns meses. À temperatura ambiente, a proteína se mantém estável somente por algumas horas, dificultando sua manipulação bem como tornando inviável qualquer tentativa de digestão por Fator Xa para remoção da GST.

Apesar das dificuldades discutidas acima, a proteina GST-S3S4 foi testada em RIA, visando avaliar sua porencialidade de uso no diagnóstico sorológico da doença de Chagas. Resultados ainda preliminares mostraram um desempenho sensivelmente inferior ao obrido pela proteína $\beta$-gal-B12. Esse fato é surpreendente na medida em que, conforme discutido acima, $\beta$-gal-B12 contém cerca de 6 repetições seriadas, ao passo que GST-S3S4 nāo somente é composta de 22 repetições seriadas, como também do domínio da reperiçāo de 173 aminoácidos (ver Figuras 11 e 12). Uma possível explicação é que a de que a proteína precipitada com SDS e ressolubilizada em tampão alcalino pudesse ainda estar contaminada com o detergente. Esse fato poderia diminuir sua eficiência de adsorção nos poços da microplaca ou ainda dificultar o reconhecimento do antigeno pelos anticorpos. Futuramente serāo feitos ensaios para a medição do grau de adsorção à placa, bem como pretende-se submeter a solução da proteína a uma cromatografia em resina $A G$ il A8 (BioRad), a fim de remover o SDS. Entretanto, alguns ensaios feitos com a GST-S3S4. purificada por cromatografia de afinidade em GSH-agarose e livre de SDS, também revelaram uma eficiência inferior a $\beta$-gal-B12.

Os ensaios realizados com GST-S3S4 resultaram em um alto ruido de fundo. Soros normais testados frente à proteína apresentaram uma alta reatividade, fazendo com que a diferença de sinal em relação a soros chagásicos fosse pequena. As baixas sensibilidade e especificidade parece ser uma característica desse antígeno, e nāo uma conseqüência do tipo de proteína de fusāo empregada ou de sua forma de purificação. Nesse caso, o antigeno Bl2 nāo poderia ser indicado como reagente para testes de sorodiagnóstico da doença de Chagas.

Apesar da menor sensibilidade do antigeno $\beta$-gal-B12, foi observado que alguns soros chagásicos provenientes da região de Bambui (MG), que não apresentaram reatividade a B13, eram positivos para B12 (Zingales et al., 1990). Essa observação sugere a existência de uma variabilidade na população de anticorpos gerada durante o curso da doença de 
Chagas, resultante das cepas infectantes de $T$. cruzi, e/ou das características genéticas do hospedeiro. Há tempos atrás, foi cedido ao Dr. Jerry Manning (UC Irvine) o mesmo painel de soros de Bambuí utilizado no presente estudo, a fim de avaliar a resposta de anticorpos ao antigeno de $90 \mathrm{kDa}$ clonado por esse grupo (Beard et al., 1988). Os autores concluíram que somente $60 \%$ dos soros testados reconheceram o antígeno de 90kDa. Para fins diagnósticos e visando reduzir o efeito da variação da resposta imunológica em distintos pacientes, surge a possibilidade de utilizar dois ou mais antigenos recombinantes em cada reste sorológico.

Conforme relatado (Zingales et al, 1990), a mistura dos antígenos B12 e B13 no mesmo poço do RLA permitiu corrigir, para os soros de Bambú, os resultados falsosnegativos encontrados para cada um dos antigenos utilizados em separado. Entretanto, essa abordagem somente parece interessante nos casos em que se deseja o máximo de sensibilidade. Uma vez que Bl2 apresenta menor especificidade do que Bl3, sua presença poderia levar concomitantemente a um aumento do número de falsos-positivos. A utilização de mais de um antigeno recombinante, de forma simultânea, foi feita com sucesso com as proteínas CRA e FRA (Krieger et al., 1990). Quando esses antígenos foram utilizados conjuntamente em ELISA (Krieger et al, 1992), houve uma distinção mais clara entre soros negativos e aqueles próximos da linha de corte ("borderline"). Os autores atribuem esse resultado ao fato de esse procedimento favorecer as respostas de alta afinidade dos soros, independentemente do título de anticorpos. Contrariamente ao observado com o uso de $\mathrm{B} 12+\mathrm{B} 13$, o uso conjunto de CRA + FRA não levou a um incremento no número de falsos-positivos, embora o número de soros de pacientes com outras parasitoses tenha sido muito pequeno para permitir uma conclusāo definitiva. No caso de Bl2 e B13 foram testados 38 soros de pacientes com outras parasitoses, numa amostragem global de 128 soros (ver Tabela I). Apesar desse número ainda ser relativamente pequeno, foi possivel verificar que o antígeno B13 não mostrou reatividade cruzada com anticorpos de outras parasitoses, com a exceção de um soro de um paciente com leishmaniose. $\mathrm{O}$ antígeno $\mathrm{B12}$, por sua vez, apresentou um elevado grau de reações cruzadas indesejáveis. Uma análise mais rigorosa, feita com um número mais elevado de soros, poderia comprovar melhor a especificidade de Bl3.

Frente aos dados obtidos, sugere-se que a diferença de reatividade para o antŕgeno B1 2 ou B13 parece ser um reflexo da caracteristica genética do paciente no que tange ao tipo de anticorpos produzidos tanto a nivel quantitativo (massa, afinidade e especificidade) quanto qualitativo. Essa observação abre perspectivas interessantes como, por exemplo, o estudo da persistência ou não da resposta a um determinado antígeno ao longo de um tratamento quimioterápico. Se considerarmos que essa diferença de reatividade também poderia ser atribuida à variação da constituiçāo antigênica das diferentes cepas de $T$. cruzi, então esse antígeno marcador, para ser eficiente, teria que ser ubíquo nas cepas do parasita. 
Em outras palavras, a pergunta que se formula é: é possivel utilizar a resposta imunológica a determinado antígeno como critério de cura ou melhoria da patologia?

Nessa direção, foi relatada a existência de duas classes de anticorpos contra $T$. cruzi em infecçōes experimentais em camundongos (Krettli \& Brener, 1982). Animais infectados, assim como aqueles imunizados com parasitas mortos ou com frações celulares, produzem anticorpos detectados por testes sorológicos convencionais como imunofluorescência indireta de parasitas fixados e fixaçāo do complemento. Por outro lado, foi verificado que somente os amiraais infectados apresentam anticorpos chamados "protetores" ou "líticos", que podem ser detectados por testes de lise de tripomastigotas mediada por complemento e imunofluorescência indireta de parasitas vivos. Foi ainda observado que pacientes chagásicos crônicos apresentam as duas classes de anticorpos. Quando submetidos a quimioterapia, alguns pacientes podem tornar-se soronegarivos para os testes convencionais e para a lise mediada por complemento. Outra fração de indivíduos tratados torna-se negativa para a lise mediada por complemento, mas mantém-se soropositiva para os demais testes (Krettli et al,, 1982). Esse último grupo de pacientes foi denominado "dissociado". Baseados no fato de que a produção de anticorpos "líticos" somente seria induzida por parasitas vivos, os autores sugeriram que o desaparecimento de anticorpos "líticos" poderia ser utilizado como critério de cura dos pacientes.

Recentemente foi observado que a maior parte da reatividade dos soros do grupo "dissociado", frente aos testes sorológicos convencionais, se deve à presença de anticorpos contra o epitopo galactosil $\alpha(1-3)$ galactose presente em antigenos de $T$. cruzi e em muitos microrganismos da flora gastrointestinal e pulmonar (Gazzinelli et al., 1993). Por outro lado, foi observada uma correlação de $70 \%$ entre a reatividade de anticorpos ao antígeno de T. cruzi GP57/51 e a lise mediada por complemento em pacientes chagásicos crónicos. Uma vez que a glicoproteína GP57/51 nào possui o epitopo Gal $\alpha(1-3) \mathrm{Gal}$, os autores propuseram seu uso como marcador molecular relacionado à cura de pacientes, substituindo o teste de lise mediada por complemento. Esses autores tambèm verificaram que antigenos liberados por tripomastigotas para o meio de cultura apresentam uma boa correlação com a presença de anticorpos líticos. De fato, foi demonstrado por Umezawa et al. (1993) que esse antigenos induzem a produçāo de anticorpos lítícos em coelhos e camundongos. Esses anticorpos líticos reconhecem uma variedade de antigenos (Umezawa et al., 1993). Ensaios de imuno-seleção de anticorpos líticos demonstraram que frações de anticorpos dirigidos contra antígenos protéicos das faixas de $70-90 \mathrm{kDa}$ e 100-120 kDa promoviam a mais alta taxa de lise mediada por complemento (50\%), comparável àquela obtida por anticorpos contra antígenos totais de tripomastigotas (58\%). Por outro lado, anticorpos dirigidos contra a faixa de 50-60 kDa somente promoveram $20 \%$ de lise. 0 conjunto desses resultados sugere que outros antígenos além da GP57/51 podem estar correlacionados com a presença de anticorpos líticos e, inclusive, em maior grau. Portanto, a 
busca de outros antígenos com reatividade correlacionada à lise mediada por complemento deveria ser incrementada, visando obter marcadores mais eficientes. A proteína B 13, por ser amplamente reconhecida por soros de pacientes crônicos e ter um peso molecular compativel com os antígenos majoritariamente reconhecidos por anticorpos líticos, poderia ser uma boa candidata e deverá ser restada futuramente.

Em nossa avaliação, a utilizaçāo do teste de lise mediada por complemento como parâmetro de cura está embasada em um conjunto sólido de dados do grupo da Dra. A. Krettli (UFMG), especialmente se considerarmos os estudos de acompanhamento de pacientes ao longo de vários anos. Entretanto, não há uma análise conclusiva quanto à efetiva cura parasitológica dos indivíduos dos grupos curado e "dissociado". Dados de acompanhamento clinico, parasitológico e sorológico parecem sugerir que pacientes com lise negativa estariam de fato curados (Krettli et al., 1982). Entretanto, está amplamente demonstrado na literatura que os testes de xenodiagnóstico, exame direto e hemoculrura apresentam uma baixa sensibilidade na detecção do parasira. Neste sentido, a utilização de sondas de DNA, que demonstram direta e sensivelmente a presença do parasita no paciente, seria fundamental na confirmação das conclusões acima. Dados recentes do grupo do Dr. Carlos Morel (FIOCRUZ - RJ) indicam que sondas dirigidas para o DNA do cinetoplasto de $T$. cruzi são capazes de diagnosticar uma infecção ativa (Wincker et al., 1994). A questão fundamental, que ainda está por ser respondida, é se a ausência de anticorpos líticos reflete um determinado nível de equilibrio na relaçāo parasita-hospedeiro, ou a eliminaçāo total dos parasitas do paciente. Pacientes chagásicos considerados curados, mas apresentando deficiências imunológicas (imunosuprimidos), seriam especialmente interessantes para esse propósito, pois poderiam revelar alterações nesse equilibrio.

Com relaçăo à fase aguda da doença de Chagas foi relatado que pacientes desenvolvem um nivel elevado de anticorpos da classe IgM, que desaparece com a cronificação da doença (Brener, 1980). Realizamos alguns testes nos quais se investigou a reatividade de anticorpos da classe IgM para Bl3 em soros chagásicos agudos. Numa amostra de 20 individuos em fase aguda o antígeno Bl3 foi reconhecido por $70 \%$ dos pacientes, sendo $70 \%$ por anticorpos da classe IgM e $65 \%$ por anticorpos do tipo IgG (Umezawa et al, 1994). O grupo do Dr. Carlos Frasch (Frasch \& Reyes, 1990; Reyes et al., 1990), analisando 10 soros de recém-nascidos com Chagas congênito, verificou que o antígeno 2 reagiu com 2 soros, ao passo que o antígeno SAPA (Affranchino et al., 1989) reagiu com 7 soros, sendo reconhecido por anticorpos das classes IgG e IgM. Quanto à proteína B12, verificamos que foi reconhecida por alguns dos soros agudos e, nesses casos, o reconhecimento também foi por IgM.

Nossos resultados sobre o desempenho de B13 no diagnóstico de pacientes chagásicos crônicos, levaram a empresa argentina Polychaco ${ }^{\circ}$ S.A.I.C. a propor a padronização de um teste de ELISA com esse antígeno. O teste de ELISA permite processar 
múltiplas amostras em sistemas automatizados e se tomou uma técnica rotineiramente empregada em laboratórios clínicos. Além disso, não faz uso de radioisótopos e pode facilmente ser adaptada para uso em bancos de sangue. Os resultados, obtidos a partir de um total de 209 soros, mostraram que B13 pode ser eficientemente empregado em testes de ELISA. Seu desempenho, em termos de sensibilidade, é tão bom quanto o das técnicas sorológicas convencionais. Além disso, a utilizaçāo de B13 é mais segura porque não requer o cultivo do parasita, mas somente da bactéria produtora. Finalmente, seu desempenho em termos de especificidade rende a ser melhor, uma vez que as técnicas convencionais utilizam o conjunto dos antigenos de $T$. cruzi, os quais apresentam reatividade cruzada com outros parasitas, especialmente Leishmania (Camargo \& Rebonato, 1969) e $T$. rangeli. De fato, relata-se que $T$. cruzi compartilha cerca de $30 \%$ de seus antígenos com Leishmania e $60 \%$ com T. rangeli, um tripanossomatidio năo patogênico (Afchain et al., 1979).

Devemos salientar que a proteina recombinante B13 utilizada nos testes está ligada à B-galactosidase. Embora tenhamos observado uma baixa reatividade dos soros de chagásicos frente a essa última proteina, esta poderia contribuir para certa inespecificidade do antigeno recombinante. A clivagem das proteínas de fusão com fator Xa poderia permitir a eliminação da $\beta$-galactosidase do restante da proteína. Esta abordagem, no entanto, apresenta dois problemas. Em primeiro lugar, um método de diagnóstico deve ser barato. A clivagem por fator Xa aumentaria muito o custo de produçāo do antigeno. Por outro lado, a eficiência de digestão por essa protease pode ser variável. De fato, em nossas condiçōes experimentais, sempre tivemos uma baixa eficiência, mesmo urilizando diferentes lotes da protease. Dos grupos que expressaram suas proteínas no vetor pMSgtll, somente um relatou sucesso na digestāo com fator $\mathrm{Xa}$ e posterior uso em diagnóstico (Almeida et al., 1990). Uma alternativa barata para solucionar esse problema seria a expressão desses antígenos na forma de proteinas nāo fundidas com antígenos bacterianos. No entanto isto implica na padronização de técnicas eficientes de purificaçāo.

Uma altemariva à utilizaçāo dos annigenos recombinantes, produzidos por bactérias, é o emprego de peptídios sintéticos. Uma parcela muito significativa dos antigenos de $T$. cruzi, clonados até o momento, apresenta regiōes imunodominantes compostas de repetições seriadas de aminoácidos. Peptidios sintéticos, compostos de uma ou mais unidades repetitivas, poderiam conter os determinantes antigênicos presentes na proteína nativa e serem utilizados em ensaios de ELISA. O primeiro teste de utilizaçāo de peptídios sintéticos foi realizado com peptídios derivados dos antigenos 1, 2, 13, 36 e SAPA (Vergara et al., 1991), clonados previamente pelo grupo do Dr. Carlos Frasch (Ibañez et al., 1987; Ibañez et al., 1988; Pollevick et al., 1991). Os autores utilizaram um ensaio imunoradiométrico (IRMA) e testaram um total de 34 amostras de soros coletadas no Chile. Foi observada uma ótima correlação entre a reatividade ao conjunto dos peptidios e os testes de imunofluorescência indireta e ELISA com extrato solúvel de epimastigotas. 
Individualmente o peptídio com o melhor desempenho foi aquele derivado do antígeno 2 (homólogo ao antigeno B13 descrito neste trabalho), que apresentou uma sensibilidade de 91\%. Os peptídios derivados dos clones 1 e 13 apresentaram uma sensibilidade de 44\%, enquanto os peptidios derivados de 36 e SAPA tiveram 65\% e 36\%, respectivamente. Posteriormente os peptidios 1, 2, 30, 36 e SAPA foram testados em ensaios de ELISA (Vergara et al., 1992) com um total de 60 soros. Foi observada uma correlação entre os resultados de IRMA e ELISA e, novamente, o peptídio 2 apresentou o melhor desempenho, com uma sensibilidade $93 \%$.

A eficiência de um ou outro peptídio para o diagnóstico sorológico pode refletir a presença de epitopos estimuladores de linfócitos B. Esse aspecro específico foi estudado quando se comparou a resposta imune à proteina do clone TcD (Burns et al., 1992), homólogo ao antígeno 13 (lbañez et al., 1988). O clone TcD apresenta repetições seriadas de 10 aminoácidos, enquanto o antígeno 13 contém repetiçōes de 5 aminoácidos. Um peptídio sintético derivado do clone TCD foi reconhecido por $96,7 \%$ de um total de 120 soros de pacientes chagásicos em testes de ELISA (Burns et al., 1992). Esse resultado difere muito daquele observado para o antigeno 13, que obteve uma sensibilidade de apenas 44\% (Vergara et al., 1991). Segundo os autores (Burns et al, 1992), o mapeamento do epitopo de $T c D$ demonstrou que peptidios contendo somente a repetiçăo de 5 resíduos não apresentam uma porção essencial do epitopo dominante para a célula B. Na verdade, a diferença entre as duas seqüências se resume à substituição de uma prolina a cada repetição do $T c D$ (KSAEPKPAEP) por uma serina no antígeno 13 (KSAEPKSAEP). Em outro estudo, os peptídios derivados de TCD e do clone 2 (Ibañez et al., 1987; 1988 - homólogo a B13) foram comparados frente a 260 soros positivos e negativos em ELISA (Peralta et al., 1994). Os resultados demonstraram uma sensibilidade de $93 \%$ e $91 \%$ respectivamente, em ensaios individuais. Quando uma mistura dos dois peptídios foi utilizada nos testes, a sensibilidade foi maior do que 99\%. A especificidade da mistura de antigenos foi de $99 \%$, comparável à obtida por hemaglutinação e superior às especificidades da imunofluorescência indireta (94\%) e do ELISA com extrato total de T. cruzi (95\%).

O conjunto dos resultados discutidos acima abre a possibilidade da utilização de peprídios sintéticos em ensaios de ELISA. O emprego de mais de um peptídio sintético poderia atingir teoricamente uma sensibilidade tão alta quanto aquela obtida pelo conjunto de técricas sorológicas convencionais, aliada a uma especificidade superior.

Em resumo, dentre os antígenos de $T$. cruzi caracterizados e testados, B1 3 se revelou um dos mais promissores para a composiçăo de um novo teste sorológico para a doença de Chagas. Conforme foi evidenciado por nosso grupo e por outros, esse antigeno obteve um bom desempenho tanto em testes de RIA como por ELISA. Além disso, pode ser utilizado na forma de proteína recombinante ou como peptidio sintético. Essa versatilidade poderia 
permitir seu emprego em diferentes formatos de teste, na dependência dos recursos e equipamentos disponiveis em cada região.

\subsection{Identificaçāo e caracterizaçāo dos antigenos clonados}

A identificação das proteinas nativas, correspondentes aos antigenos clonados B12 e B13, foi feita por Western blot. Os anticorpos foram obtidos pela imunizaçāo de coelhos e por imuno-seleção a partir de soros de humanos chagásicos. Verifica-se para Bl3 uma concordância entre os resultados obtidos com anticorpos de chagásicos imunoselecionados e com o soro de coelho anti- $\beta$-gal-B13 (Figuras 6A e 6D tiras e). Os resultados encontrados com o clone Bl3 são diferentes daqueles obtidos por Hoft et al (1989) com o clone TCR39 (homólogo a Bl3). Enquanto obtivemos reatividade com bandas de 140 e $116 \mathrm{kDa}$ nos diferentes ensaios, esses autores, utilizando anticorpos de chagásicos imuno-selecionados, obtiveram reatividade com bandas de 75 a $105 \mathrm{kDa}$. Ibañez et al. (1987), com o clone 2 (também homólogo a B13) detectaram por imuno-seleção uma banda de $85 \mathrm{kDa}$. A discrepância entre nossos resultados com aqueles obtidos por esses autores pode ser creditada a diversos fatores.

A primeira possibilidade é de que haja variaçōes antigênicas entre as diferentes cepas empregadas pelos pesquisadores. Essa hipótese estaria de acordo com os resultados encontrados por Macina et al. (1989), que demonstraram a existência de polimorfismo nos genes homólogos aos clones 7 e 30 de Ibañez et al. (1987). Foi verificado que genes homólogos, em diferentes cepas, apresentam grandes variações do número de repetiçòes seriadas. Nosso grupo também observou esse polimorfismo para o cione B13 entre as cepas Y e CL (ver Figura 3). Uma objeção a essa hipótese é o fato de que o tamanho encontrado para os mRNA homólogos a Bl3 (clone 2 e TCR39) ter sido semelhante entre os três grupos. Quando analisamos esses mRNAs, verificamos a existência de duas espécies de 3,5 e 4,2 kb (Figura 4). Considerando um peso molecular médio de 110 por aminoácido, esse mRNAs codificariam proteínas de 128 e $154 \mathrm{kDa}$, que são valores próximos àqueles encontrados por nosso grupo para os antigenos do parasita. Obviamente esse cálculo não leva em conta possíveis glicosilações e outros processamentos pós-traducionais.

A segunda hipótese para explicar essas discrepâncias é de que o processamento póstraducional ocorreria por vias distintas em diferentes cepas. Contudo, como as diferenças encontradas chegam a ser maiores que $70 \mathrm{kDa}$, essa hipórese parece pouco provável. Finalmente, é possível que as bandas observadas por Ibañez et al (1987) e Hoft et al. (1989) sejam produtos da degradação parcial da proteína nativa. Em nossos Western blots também foram visualizadas bandas de menor peso molecular (ver Figura 3A, tira $d$ ). Acreditamos que essas bandas sejam produtos de degradaçāo intracelular do antigeno ou resultantes de degradação proteolítica após a lise das células. Vale ressaltar que a todos os lisados 
empregados nos ensaios de Western blot e imunoprecipitaçāo foram adicionados inibidores de proteases. Com relação ao reconhecimento de annigenos de 140 e $116 \mathrm{kDa}$, o fato de anticorpos humanos e de coelhos apresentarem reatividade semelhante, garante uma boa confiabilidade ao resultado. Além disso, os ensaios foram repetidos várias vezes, com diferentes lisados, demonstrando sempre alta reprodutibilidade.

Resultados mais esclarecedores surgiram quando o grupo do Dr. Carlos Frasch apresentou a seqüência completa de um gene homólogo a Bl3, isolado da cepa CA-1 (Buschiazzo et al. 1992). Foi verificado que o produto protéico teria cerca de $155 \mathrm{kDa}$ e, portanto, em contradição com os resultados previamente obtidos por aquele grupo (Ibañez et al., 1987). Quando esses autores passaram a congelar os parasitas a $-70^{\circ} \mathrm{C}$ e descongelálos imediatamente no tampão de amostra seguindo-se uma fervura, foram detectadas bandas de 140 e $160 \mathrm{kDa}$. Esses resultados são muito próximos daqueles obtidos por nosso grupo e parecem indicar que, de fato, a proteína nativa é bastante lábil.

Um outro resultado discrepante entre os grupos é a expressão do gene Bl3 nas diferentes formas evolutivas do parasita. Nossos resultados mostram que as espécies de mRNAs, homólogas a Bl3, sāo encontradas em formas epimastigotas e tripomastigotas (Figura 4). Além disso, os antígenos de 140 e $116 \mathrm{kDa}$ também foram detectados nas duas formas evolutivas (ver figura $3 \mathrm{~A}$ e $3 \mathrm{~B}$, tiras $d$ ). Hoft et al. (1989) detectaram as espécies de mRNAs, bem como os antigenos em formas epimastigotas ao passo que lbañez et al. (1987) relataram que ranto os mRNAs como os antígenos seriam tripomastigota-especificos. A hipótese de que nossa cultura de epimastigotas pudesse conter uma grande população de tripomastigotas metacíclicos não procede, uma vez que contagens demostraram que a taxa de diferenciação dos parasitas era inferior a 5\%. Não sabemos explicar a razão da discrepância de resultados com o grupo de Carlos Frasch.

Com relação à proteína $\mathrm{B} 12$, os anticorpos humanos imuno-selecionados não detectaram nenhuma banda em Western blot (Figura 3D, tira c). Os anticorpos de coelhos imunizados com $\beta$-gal-B12 reagiram com bandas de $200 \mathrm{kDa}$ e $230 \mathrm{kDa}$ em epimastigotas e tripomastigotas, respectivamente. A proteína nativa, a exemplo de B13, parece ser bastante lábil, uma vez que Western blots feitos a partir de diferentes lisados frequientemente levavam à detecção de bandas de peso molecular inferior. A baixa reatividade do soro anti$\beta$-gal-B12 frente ao lisado de $T$. cruzi poderia ser atribuida à relação entre o tamanho da proteina codificada por B12 (13 kDa) e o tamanho da $\beta$-galactosidase (l16 kDa), o que determinaria que epitopos importantes de Bl2 poderiam estar em conformaçāo desfavorável (crípticos) na proteína de fusão e nāo gerarem anticorpos. A subclonagem do fragmento S3S4 (ver Figura 8) teve como objetivo a produção de uma proteina com cerca de $95 \mathrm{kDa}(68 \mathrm{kDa}$ de 5354 e $27 \mathrm{kDa}$ da GST), que poderia ter uma exposição favorável dos epitopos homólogos a B12. Além disso, o fragmento \$3S4 também apresenta a seqüência da repetiçāo de 173 amínoácidos (ver Figura 12), a qual poderia aumentar a variedade de 
anticorpos produzidos. O soro anti-GST-S3S4 obtido reconheceu urn antígeno de peso molecular superior a $200 \mathrm{kDa}$ (dados não mostrados) em lisados de epimastigotas, confirmando os dados obtidos com o soro anti- $\beta$-gal-B12. Entretanto, a reatividade observada nāo foi superior, embora o soro anti-GST-S3S4 reconhecesse fortemente a proteína $\beta$-gal-Bl 2 e vice-versa. Esse fato sugere que a fraca reatividade observada pode nāo ser devida aos soros empregados, mas sim à baixa estabilidade e/ou expressão da proteína nativa no parasita. Isso explicaria ainda os dados de um baixo desempenho da proteína B12 no diagnóstico sorológico.

Um dado interessante é que o soro anti-GST controle reconheceu intensarnente por Western blot antígenos com um peso molecular de 54 a $59 \mathrm{kDa}$, tanto em formas epimastigotas como tripomastigotas (dados não mostrados). Esse resultado sugere que a GSTs de Schistosoma japonicum e $T$. cruzi podem ter uma homologia significativa e compartilhar epitopos. A presença de GST em $T$. cruzi foi descrita pela primeira vez por Yawetz \& Agosin (1981). Esses autores purificaram a enzima a partir de frações citossólicas de formas epimastigotas. O peso molecular da enzima nativa foi estimado em 37.000, apresentando duas subunidades de 20.000 e 17.000 , respectivamente. Mais recentemente foram descritas proteinas de $T$. cruzi, com um peso molecular de 45, 30 e $26 \mathrm{kDa}$, purificadas por cromatografia de afinidade em resina de glutationa reduzida (PlumasMarthy et al, 1992). O mesmo grupo também relatou a clonagem de uma proteína de 52 kDa com homologia a GSTs e proteínas relacionadas a "stress" (Schöneck et al, 1994). A GST tem um papel muito importante em processos de detoxificaçāo. Sua função consiste em catalisar reaçōes de formaçāo de conjugados entre a glutationa e compostos eletrofílicos (cf. Morello, 1988). Essas reações de detoxificações são especialmente importantes na resistência dos parasitas às drogas nifurtimox e benzonidazol (Moncada et al. 1989). O desenvolvimento de agentes quimioterápicos mais eficientes e menos tóxicos é um importante ramo da pesquisa em doença de Chagas. A ampliaçāo do conhecimento dos mecanismos moleculares de defesa do parasita contra a açāo de drogas pode levar ao desenvolvimento de quimioterápicos muito mais eficientes, dirigidos contra alvos específicos. Pelo fato de o $T$. cruzi não possuir catalase, ser deficiente em peroxidase e apresentar um baixo núvel de superóxido dismutase, torna-se vulnerável à ação de drogas como o nifurtimox e benzonidazol. No entanto, essas drogas formam radicais livres intermediários, os quais podem ser metabolizados via ação da GST, levando à neutralizaçāo ou reduçāo de seu efeito tóxico (cf. Morello, 1988). O conhecimento da estrutura e mecanismo de catálise da GST de T. cruzi poderả gerar subsidios para o desenho de drogas específicas, visando a inibição dessa enzima e, conseqüentemente, o aumento da eficácia dos quimioterápicos já disponíveis.

Com relaçāo à distribuiçāo celular dos antígenos B12 e B13, foi demonstrado por imunoprecipitação de parasitas radioiodados que as proteínas Bl2 e Bl3 não estão 
presentes na superficie de formas epimastigotas. Entretanto, em tripomastigotas, a espécie de 140 kDa de Bl3 foi precipitada, indicando que esta proteína está localizada na superfície do parasita. Esse resultado está de acordo com a observação de Ibañez et al. (1988) em ensaios de imunofluorescência indireta. Contudo, apesar de dois outros grupos terem clonado esse antigeno (lbañez et al., 1987; Hoft et al., 1989), sua localização celular por imunoprecipitação, não tinha sido estabelecida até o momento. Quanto a B12, os resultados da imunoprecipitação, realizada com o soro anti- $\beta$-gal-B12, sāo inconclusivos. Houve uma fraca precipitação de proteínas na faixa de 150 a $170 \mathrm{kDa}$. Embora vários ensaios tenham sido feitos, não houve reproduribilidade. Pretende-se no fururo repetir esse ensaio com o soro anti-GST-S3S4, embora resultados preliminares em Westem blot sugiram que esse soro também apresenta fraca reatividade decorrente da baixa representatividade e/ou estabilidade da proteína nativa no parasita. Admitindo que a proteína B12 esteja localizada na superfície do parasita, as bandas de 150-170 kDa observadas seriam produtos de degradaçāo parcial. Ensaios de imunofluorescência indireta, utilizando os soros anti-B12 e anti-B13, também não foram conclusivos (dados não mostrados). Mesmo utilizando várias diluições dos soros, somente foi possivel observar uma reatividade fraca espalhada ao longo de toda a célula do parasita.

Ao analisarmos o conjunto desses resultados verificamos que, no caso de B13, duas espécies antigênicas de 140 e 116 kDa sāo detectadas por Westem blot nas formas epimastigotas e tripomastigotas. Entretanto somente a espécie de $140 \mathrm{kDa}$ está localizada na superficie de tripomastigotas. O significado biológico desse evento ainda nāo é conhecido. É possivel que esse antigeno esteja relacionado com algum processo necessário para a adesão e/ou interiorização do parasita na célula do hospedeiro ou com mecanismos de evasão ao sistema imune do hospedeiro, especialmente importantes na forma tripomastigota. É possivel que os antígenos de 140 e 116 kDa derivem da rradução concomitante dos mRNAs de 3,5 e 4,2 kb, que também sāo transcritos nas duas formas evolutivas (ver Figura 4). Levando em conta que o gene B13 está localizado em dois alelos (Henriksson et al., 1990), uma hipótese alternativa é a de que cada um dos transcritos derive de cada alelo. $\mathrm{O}$ antigeno de $140 \mathrm{kDa}$, codificado por um dos mensageiros, poderia conter sinais para seu direcionamento para a superfície do parasira. No entanto, esse direcionamento poderia requerer um processamento pós-traducional tripomastigotaespecífico. A verificação desta hipótese è bastante complexa, envolvendo, numa primeira etapa o isolamento e seqüenciamento de clones contendo cada um dos alelos do gene B13. Ensaios de pulso e caça em formas epimastigotas e tripomastigotas, utilizando [ ${ }^{35} \mathrm{~S}$ ] metionina, poderiam ajudar a evidenciar um possivel processamento, bem como demonstrar a possivel existência de moléculas precursoras. É interessante salientar que dados de sequiência obtidos pelo grupo de Carlos Frasch para um gene homólogo a B13 não mostraram a presença de seqüència sinal amino-terminal ou de uma região hidrofóbica 
carboxi-terminal compatível com adição de âncoras via glicosil-fosfatidilinositol (Buschiazzo et al, 1992).

\subsection{Caracterização dos transcritos dos genes B12 e B13}

Os resultados obtidos em Northern blot (Figura 3) indicam que os transcritos dos genes B12 e Bl3 estão presentes nas formas epimastigotas e tripomastigoras do parasita. Nāo foram detectadas variações do tamanho dos transcritos entre as duas formas evolutivas. No caso de Bl 2 foram identificados dois transcritos de 7,2 e 8,8 kb (ver também Figura 18). Os dados do seqüenciamento completo do gene B12 (Figura 12) demonstraram a existência de uma ORF de 6.342 pb, codificando uma proteína de 2.114 aminoácidos. Considerando-se a sequiência primária dessa proteina, pode-se estimar um peso molecular de $223 \mathrm{kDa}$. Esse valor é bem próximo dos pesos moleculares encontrados em Western blots para epimastigotas $(200 \mathrm{kDa})$ e tripomastigotas $(230 \mathrm{kDa})$, respectivamente (Figuras $6 \mathrm{~A}$ e $6 \mathrm{C}$, tiras $\mathrm{c}$ ). A diferença de tamanho entre a ORF de B12 e as espécies de mRNA detectadas por Northern blot pode ser amibuída a erros de cálculo do tamanho das bandas de mRNA (admitem-se erros de até 10-15\%) e/ou à existência de extensas regiões não codificantes nos mRNAs. O fato de somente uma classe de antigeno ter sido detectada pode significar que somente uma das espécies de mRNA é traduzida. Outra alternativa é que em cada forma evolutiva ocorre a tradução de um dos transcritos.

No caso do clone Bl3, existem dois transcritos de respectivamente 3,5 e 4,2 Kb. Esses valores são compativeis com o tamanho estimado do gene em seus dois alelos (Henriksson et al., 1990; Buschiazzo et al., 1992), bem como com os tamanhos observados por Hoft et al. (1989) e Ibañez et al. (1987) para os transcritos de genes homólogos a B13. Nāo sabemos se ambos os transcritos são traduzidos, ou se uma das especies é um produto de processamento da outra. Admitindo-se um peso molecular médio de 110 Da para cada aminoácido, estes transcritos codificariam proteínas de 128 kDa e 154 kDa. Esses valores não consideram possiveis regiōes não codificadoras, mas mesmo assim sāo bastante semelhantes aos encontrados em Western blot (Figuras 6A, 6B e 6C, tiras $d$ ). Devemos salientar nosso desconhecimento quanto ao grau de glicosilação desse antígeno.

\subsection{Artefatos de recombinação}

Os clones B12 e B13 foram utilizados como sondas para a varredura de uma biblioteca genômica no vetor $\lambda E M B L 3$. A obtenção de 4 clones genômicos permitiu estabelecer o mapa de restriçāo de uma regiāo de $32 \mathrm{~kb}$ que contém os genes Bl2 e B13. Entretanto, conforme relatado no item 3.13 (ver também Figura 8), os clones BGE7 e BGE14 apresentaram regiões deletadas, especialmente nas regiões de repetições seriadas. 
Inicialmente pensou-se que a presença de deleções nas regiōes de repetições poderia ser resultante da heterogeneidade da população de parasitas da qual o DNA foi obtido. Dessa forma, alguns parasitas poderiam ter originalmente um número menor de repetições seriadas em cada gene. Outra hipótese é a de que as deleções seriam um artefato originado durante a replicaçăo do fago na bactéria hospedeira. Essa hipótese foi confirmada por cultivos seriados dos fagos recombinantes BGE2 e BGE7 e posteriores digestōes de seu DNA. Foi possivel observar que bandas contendo as repetições seriadas diminuiam progressivamente de tamanho, indicando um processo de deleção por artefato de recombinaçāo (dados não mostrados).

A explicação técnica para esse problema pode ser encontrada nas características genéticas do sistema fago $\lambda E M B L 3$ e hospedeira Q358 (Frischauf et al, 1987). Esse vetor de substituiçăo, derivado do $\lambda 1059$ (Karn et al., 1980), apresenta em seu fragmento central os genes red e gam. Esses genes conferem ao fago o fenótipo Spi (sensivel à interferência do fago P2), uma vez que impedem o crescimento do vetor em hospedeiras lisogênicas de P2. A vantagem desse sistema é o enriquecimento relativo da população de fagos recombinantes, os quais não contém o fragmento central. Contudo, a replicação do fago $\lambda$ na bactéria se dá inicialmente no modo $\theta$ (teta) e, posteriormente, muda para a forma de circulo rolante, de modo a gerar concatâmeros passíveis de empacotamento. Essa transição se dá pela inativaçāo de Exo $\mathrm{V}$ pelo produto do gene gam. Nāo existindo o gene gam nos recombinantes, há uma via alternativa de geração de moléculas concatenadas, através da recombinação de monômeros, mediada por recA produzida pela bactéria hospedeira. Há portanto a necessidade de se propagar os vetores recombinantes em hospedeiras recA positivas, como a cepa Q358. Uma vez que recA está envolvida com processos de recombinação, sequências repetitivas de DNA do inserto estariam mais sujeitas a deleções progressivas e/ou rearranjos genômicos durante o ciclo do vetor na bactéria hospedeira. Como solução a esse problema sugere-se a utilização de uma bactéria recA- e recBC; contendo um plasmidio auxiliar que expressa o produto de gam (Frischauf et al., 1987).

O problema apresentado acima também foi enfrentado por Macina et al. (1989). Esses autores relataram a impossibilidade de obter clones inteiros de $T$. cruzi, contendo as regiòes repetitivas e flanqueadoras, em $E$. coli recA. Uma vez que não dispúnhamos nem do plasmidio auxiliar, nem de uma hospedeira recA- e recBC-, e nossa biblioteca tinha sido construída em $\lambda E M B L 3$, decidiu-se elucidar todo o mapa de restrição com os clones BGE7 e BGE14 parcialmente deletados, e os clones BGE2 e BGE9 íntegros. Para garantir a confiabilidade do mapa de restrição da regiāo de $32 \mathrm{~kb}$, os resultados foram confrontados com um Southern blot feito com o DNA de T. cruzi (Figura 9). Os resultados obtidos confirmaram a proximidade física dos genes B12 e B13, bem corao o tamanho dos fragmentos homólogos aos clones B12 e B13 contendo as repetições. 
Ao longo do trabalho, outro artefato de recombinação foi observado no sistema M13/JM101. O fragmento B4H5 (ver Figura 8), clonado em M13mp 19, foi tratado segundo o protocolo de Henikoff (1987). Após a transfecçào das reaçōes na hospedeira JM101, foram obtidos clones deletados. Procedeu-se então ao seqüenciamento de alguns desses clones, utilizando-se o fragmento Klenow da $E$. coli DNA polimerase I (como descrito no item 2.25.2.2), objetivando a seleção daqueles com regiōes de sobreposição. Os resultados, entretanto, demonstraram que a seqüência nucleotidica desses clones estava alterada em relação àquela que havia sido previamente determinada a partir de ssDNA obtido das placas de fagos. Quando se procedeu ao seqüenciamento do DNA da forma replicativa não submetida ao tratamento com Exonuclease III os resulrados encontrados foram os mesmos. Esse fato indica que estas alterações devem ter ocorrido durante a etapa de propagação dos fagos para a preparaçāo em larga escala de DNA da forma replicativa. A seqüencia nucleotídica indicou a presença de deleções e inversōes, impedindo a obtenção de dados confiáveìs. Eventos semelhantes foram verificados no DNA da forma replicativa do fragmento E2E3 em uma das orientaçōes, mas não na outra. Problemas de recombinação são freqüentemente citados na literatura como causa de insucesso no uso de fagos filamentosos para seqüenciamento de DNA (Sambrook et al., 1989; Tripathi, 1992; Wang \& Sodja, 1991). É interessante verificar que os fragmentos B4H5 e E2E3 apresentam longos segmentos de timinas (ver Figuras 12 e 14), o que poderia levar à formação de estruturas propícias a eventos de recombinaçāo. A utilização de cepas recA ${ }^{-}$é sugerida para reduzir a possibilidade desses eventos, assim como a clonagem de fragmentos de pequeno tamanho em M13. Foi tentada então a infecção da hospedeira JMl109 com os fagos derivados das placas originais (sabidamente não deletados). Entretanto, o rendimento de fagos obtido nessa hospedeira foi extremamente baixo, inviabilizando seu uso. Decidiu-se então subclonar todos os fragmentos destinados ao seqüenciamento no vetor pBluescript ${ }^{\oplus}$ e não utilizar mais o sistema M13, visto que nāo apresenta suficiente estabilidade com nossas seqüências.

\subsection{Caracterização dos genes B12 e B13}

Os clones genômicos BGE2, BGE7, BGE9 e BGEl4, isolados da biblioteca de $T$. cruzi no vetor $\lambda E M B L 3$, tiveram seus mapas de restriçāo determinados. A sobreposiçāo dos respectivos mapas permitiu definir uma região de $32 \mathrm{~kb}$ do genoma de $T$. cruzi. Surpreendentemente foi verificado que os respectivos genes B12 e B13 estāo fisicamente muito próximos um do outro. De fato, a partir de dados de Southem blots hibridizados com B12 e B13, foi possivel determinar que a distância entre os dois genes era inferior a 2,4 kb (ver Figura 8). A proximidade física dos dois genes foi confirmada por Southern blots utilizando DNA genômico do parasita (Figura 9). Através do seqüenciamento completo do 
gene Bl2 e da regiāo 5' terminal do gene Bl3 (Figura 12), foi possivel verificar que a distância entre as regiões codificadoras é de somente 1,5 kb. É interessante comentar que a abordagem utilizada para a clonagem de Bl2 e Bl3 não favorecia a obtençāo de seqüências fisicamente relacionadas. A razão pela qual dois genes tão próximos tenham sido isolados, utilizando como sonda um soro policlonal, permanece uma incógnita. A probabilidade, ao acaso, da ocorrência de tal evento é tão baixa que gera uma indagação: será que genes com funçōes relacionadas, no caso antígenos, teriam loci próximos e até mesmo relacionados via transcritos policistrônicos? Seră interessante no futuro fazer um mapeamento do genoma de $T$. cruzi utilizando como sondas as diferentes seqüencias já caracterizadas, comparando suas funçōes e localizaçōes cromossômicas. Tal estudo deveria, obviamente, ser feito em um clone definido. Nesta direção, o clone CL Brener, foi escolhido no Projeto Genoma de $T$. cruzi e deverá ser caracterizado, podendo fornecer esclarecimentos para essa indagação (Zingales et al., 1994; Levin et al., 1994).

Henriksson et al. (1990) determinaram o mapa de restrição de uma região que contém um gene homólogo a B13, isolado da cepa CA-l de T. cruzi. A comparaçāo desse mapa com aquele determinado em nosso laboratório mostra uma similaridade bastante alta, porém o número de sítios de cada enzima é menor no mapa desses autores. Essa diferença pode ser devida a variaçōes entre as cepas $Y$ e CA-1. Outra possibilidade é de que o mapa de restrição de Henriksson et al. (1990), por ter sido determinado a partir de digestões de DNA cotal do parasita, nāo apresente a mesma resoluçāo conseguida a partir de fragmentos de DNA clonados. A probabilidade de não detectar-se um sítio, principalmente quando ele está próximo de um outro, é muito maior quando se trabalha com DNA genômico total e com genes de cópia única.

A partir dos resultados do seqüenciamento do gene 812 (Figura 12) e da extremidade 5' terminal de B13 (Figura 16) foi possivel verificar que a orientação de transcriçāo é a mesma para ambos os genes (ver também Figura 8). Essa orientação foi determinada a partir das ORFs nas seqüências e a partir da codificaçāo das repetiçōes dos insertos B12 e B13. Uma demonstração direta, contudo, poderia ser obtida mediante a hibridização de um Northern blot com sondas feitas por "primer extension" de cada uma das fitas de Bl2 e B13. A proximidade física $(1,5 \mathrm{~kb})$ das ORFs de B12 e B13 (Figuras 12 e 16), aliada ao fato de a transcrição dos genes ocorrer na mesma orientação, abre a possibilidade da existência de um transcrito comum policistrônico.

Em Northem blot hibridizado com as sondas B12 e B13 (Figura 4) não se observa a presença de nenhuma banda de alto peso molecular comum aos dois genes. $O$ mesmo resultado se verifica quando são utilizadas como sondas os DNA dos clones genômicos BGE2, 7, 9 e 14 (consulte Figura 8). Na Figura 18 observa-se que as sondas BGE7 (tira b) e BGE9 (tira c) apresentam uma fraca hibridizaçāo com espécies de alto peso molecular. Entretanto, o mesmo padrāo é observado quando se utiliza como sonda o fragmento SEl 
(ira e), levando à conclusāo que esse resultado não pode ser atribuido a um mRNA policistrônico dos genes B12 e B13. É interessante frisar que esses clones genômicos contém a região intergênica, que deveria necessariamente fazer parte de um hipotético transcrito policistrônico. Mesmo $\mathrm{cm}$ ensaios de Northern blots hibridizados com sondas feitas somente dos fragmentos E2E3 e B4H5 (consulte Figura 8) os resultados obtidos foram os mesmos (não mostrados). A hibridização observada na faixa de 1,66 a 2,4 kb (observada com os clones genômicos e com os fragmentos E2E3 e B4H5) corresponde às espécies de rRNA de T. cruzi e parece ter um caráter inespecífico. Na verdade, devido ao fato da região intergênica ser muito rica em timinas (ver Figuras 12 e 16), esca poderia hibridizar com rRNAs, que sabidamente apresentam uma elevada constituição de trechos ricos em adeninas (Arruda et al., 1990).

A despeito desses resultados, a hipótese de que B12 e Bl3 sejam transcritos em um mRNA policistrônico de alto peso molecular, com vida média extremamente curta, não pode ser descartada. Esse transcrito, uma vez processado, poderia dar origem às diferentes cspécies de RNAS visualizadas (Figura 4). Um ensaio mais sensivel, capaz de detectar a presença de um transcrito policistrônico, seria o "run-on" com núcleos isolados e marcados com l $\alpha$-32 PIUTP. O RNA nuclear nascente e radioativo seria usado como sonda em dot-blot ou Southern blot para mapear as regiões rranscritas. Como o RNA testado é nuclear c nascente, as regiōes passiveis de processamento pós-transcricional estariam preservadas e representadas na amostra. Esse ensaio deverá ser conduzido futuramente.

A existência de transcritos policistrônicos têm sido demonstrada em vários membros da ordem Kinetoplastida. González et al. (1985) relataram a presença em $T$. cruzi de uma unidade multigênica denominada IF8, constituída de 20 cópias seriadas e que, em Northern blot, revelou multímeros de precursores parcialmente processados. Em $T$. brucei foi relatada a presença de transcritos poligênicos, contendo pelo menos dois cistrons do aglomerado de genes que expressam calmodulina. Os genes de rubulina de $T$, brucei também estāo arranjados cm aglomerados, conrendo unidades alternadas de genes de $\alpha-c$ $\beta$-tubulina. Imboden et al. (1987) demonstraram por meio de um ensaio de "run-on" a existência de transcritos poligênicos contendo os dois genes bem como a região intergênica. Posteriormente foi verificado que o choque térmico era capaz de interromper a maquinaria responsável pelo "trans-splicing", levando ao acúmulo desses transcritos precursores (Muhich et al., 1988). O aumento da concentração no estado estacionário de transcritos policistrônicos de tubulina é mais acentuada à temperarura de $42,5^{\circ} \mathrm{C}$ (Muhich et al, 1989). A detecção de transcritos poligênicos de rubulina também foi reportada em $T$. cruzi (Soares et al., 1989). É possivel que os transcritos policistrônicos não constituam a regra, entretanto têm sido cada vez mais detectados em diferentes organismos da ordem Kinetoplastida e famillias de genes. Em tripanossomatídios, a obtenção de mRNAs maduros ocorre por "trans-splicing", através da clivagem do mRNA precursor e da adição da seqüência líder 
(mini-exon) a cada um dos cistrons constituintes (De Lange et al., 1984b). A ocorrência de "splicing" alternativo, via "cis-splicing", observado em outros eucariotos, ainda nāo foi verificada em membros da ordem kinetoplastida. Entretanto, observou-se que o "transsplicing" cambém pode adquirir vias altemarivas e hierárquicas (Revelard et al., 1993), dependendo principalmente da composiçào da regiào rica em polipirimidinas localizada diretamente a montante do sítio aceptor de "splícing" (Layden \& Eisen, 1988: Huang \& Van der Ploeg, 1991; Matthews et al., 1994).

Os resultados de Southern blot de DNA de T. cruzi, digerido com várias enzimas, sugerem que os genes B12 e Bl3 apresentam somente uma cópia por genoma haplóide (ver Figura 2). Na digestāo com Sall, podem ser vistas várias bandas de hibridização com Bl2, mas elas se devem à existência de três sitios internos de Sall no gene, conforme foi demonstrado pelo mapa de restrição (Figura 8) e seqüenciamento completo do gene (Figura 12). O fato de não haver outras bandas de hibridização indica que não há outras cópias desse gene dispersas pelo genoma do parasita. A hipotese de haver um aglomerado de cópias seriadas não é compativel com o mapa de restrição da região de $32 \mathrm{~kb}$ (Figura 8). Esse mapa, que inclui o gene Bl2 e regiões flanqueadoras maiores do que $10 \mathrm{~kb}$, mostra não haver outra cópia do gene B I2. A dupla de bandas observada na regiāo de $9,4 \mathrm{~kb}$ (ver digestão com Sall - Figura 2) corresponde ao fragmento $\$ 556$ (consultar o mapa de restriçāo da Figura 8), que contém parte dos genes B12 e B13. As duas bandas possivelmente se originam de dois alelos distintos que apresentam um número diferente de repetições seriadas, conforme foi observado por Henriksson et al. (1990) para um gene homólogo de B13 (ver discussāo abaixo).

No caso de B13 observa-se hibridização com uma dupla de bandas em quatro das enzimas testadas (Figura 2). Henriksson et al. (1990) também obriveram um padrão de duas bandas para um gene homólogo a B13, utilizando digestōes duplas e simples com várias enzimas. Quando esses autores fizeram um ensaio de Southern blot a partir de uma eletroforese de campo pulsado, também observaram hibridização com duas bandas, indicando a presença do gene em dois cromossomos distintos. Henriksson et al. (1990) submereram entāo o DNA de $T$. cruzi a uma eletroforese de campo pulsado na primeira dimensão, seguida de uma clivagem com HindlII e uma eletroforese convencional na segunda dimensão. Esse experimento permitiu demonstrar que a dupla de bandas, observada em digestōes com enzimas de restrição, era originária de cromossomos distintos. A partir da comparação dos mapas de restrição dos dois cromossomos os aucores concluíram que essas bandas representam diferentes alelos do mesmo gene, os quais diferem entre si pelo número de repetiçōes seriadas. As bandas observadas em campo pulsado representariam, portanto, cromossomos homólogos segundo a definição clássica.

Em nosso caso, uma digestāo de DNA de T. cruzi com Hindlll gera bandas de 4,2 e $3,5 \mathrm{~kb}$ (ver Figura 2). O clone BGE 2, quando digerido com essa enzima, apresenta uma 
banda de 3,5 kb, correspondendo ao alelo com menor número de repetiçōes seriadas. Os clones BGE 7 e BGE 14 apresentam deleçōes nas regiòes homólogas às repetições seriadas, sendo assim impossivel determinar de qual alelo derivam. Southern blots de DNA de $T$. cruzi, hibridizados com a sonda B12, mostram uma banda (ou duas bandas de tamanho muito próximo), o que sugere que, provavelmente, os dois alelos desse gene devam apresentar um número semelhante de reperições seriadas. Em vista disso, não sabemos a qual dos alelos correspondem os respectivos clones BGE2, BGE7, BGE9 e BGE14. Desta forma, o mapa de restrição da região de $32 \mathrm{~kb}$ poderia respresentar uma quimera dos dois alelos. O gene B13, assim como já foi observado para B12, parece ter apenas uma cópia por genoma haplóide. Essa conclusão se baseia não somente nos resultados de Southem blot genômico (Figura 2), como também no mapa de restrição de uma região de 32 kb (Figura 8).

A eletroforese de campo pulsado, seguida de Southern blot (Figura 24), demonstrou que os genes B12 e Bl3 estão presentes em um único cromossomo por genoma haplóide. O fato de as duas sondas hibridizarem com o mesmo cromossomo confirma a proximidade física desses dois genes, conforme demonstrado no mapa de restrição (Figura 8). O fato de não se observar a hibridização em uma dupla de cromossomos, como relatado por Henriksson et al. ( 1990$)$, parece indicar que as variaçŏes entre os supostos cromossomos homólogos na cepa Y é mcnor do que o observado na cepa CA-1. Outra possibilidade é de que as condições utilizadas na eletroforese de campo pulsado nâo tenham permitido resolver eficientemente cromossomos pertencentes à mesma faixa de peso molecular.

Um fato interessante, relacionado a $\mathrm{B} 12$ e B 13 , diz respeito à localização e arranjo dos respectivos genes no genoma e cromossomos de distintas cepas. Conforme pode ser visto na Figura 3, há uma variaçào, no tamanho das bandas observadas em Southem blots de DNAs das cepas Y e CL. Esta variabilidade rambém se observa a nivel dos cromossomos. De fato, a Figura 24 indica que as sondas B 12 e Bl 3 hibridizam com um único cromossomo de 1,26 Mb na cepa $C L, 1,41 \mathrm{Mb}$ na cepa $Y$ e 0,98 Mb na cepa $G$. Utilizando um gene homólogo a B L3, Henriksson et al. (1990) relataram pesos moleculares de 1,01/1,02 Mb nas cepas $T_{0}$ e CA-1/72, 1,3 Mb na cepa $T_{2}, 1,07 \mathrm{Mb}$ na cepa $R A$ e 0,98/1,01 Mb na cepa Dm 28c. Há, portanto, uma boa concordância entre os nossos resultados e aqueles obtidos por esses autores, tanto em relação à ocorrência de variabilidade entre cepas, como também quanto à faixa de tamanho do cromossomo que contém o gene Bl 3.

A heterogeneidade cariotipica entre diferentes cepas de $T$. cruzi e mesmo entre diferentes isolados de uma mesma cepa já foi observada em géis de campo pulsado hibridizados com sondas de diferentes genes (Engman et al, 1987; Aymerich et al, 1989). Não foram detectadas variações após a diferenciação da forma epimasrigota para o tripomastigota metacíclico (Aymerich et al. 1989). O genoma de tripanossomatídios apresenta uma plasticidade muito grande, com grande tolerância para suportar alterações no número e tamanho dos seus cromossomos. Uma demonstração notável desse 
plasticidade foi obtida após tentativas de duplo "nocaute" do gene da diidrofolato redutasetimidilato sintase de Leishmania major, um gene essencial desse parasita. As linhagens duplo-mutantes obtidas demonstraram alreraçōes no seu genoma, apresentando eventos de terraploidia e aneuploidia (Cruz et al., 1993). Essa alta plasticidade e heterogeneidade talvez seja decorrente do fato de não existir ou não ser freqüente a reprodução sexuada nesses parasitas (Vickerman, 1986). Dessa forma, as populações do parasita, ao invés de uma 'strutura sexual, seriam preferencialmente multiclonais (Tibaysenc et al., 1986; Tibayrenc \& Ayala, 1987). Dentro dessa perspectiva, a obtençāo de mapas de "linkage" de diferentes genes em várias cepas seria muito interessante. Esses dados poderiam auxiliar o cntendimento das relaçōes fílogenéticas entre as diferentes cepas, da organizaçāo do genoma do parasita e da geraçāo dessa heterogeneidade. Nesse sentido, a caracrerizaçāo dos genes B 12 e B 13 e a comprovação de que estão fisicamente ligados oferece um caminho importante de investigação. Desta forma, seria interessante, por exemplo, verificar se cxistem cepas nas quais esses genes estāo presentes em cromossomos distintos. Além disso, sendo genes de cópia única e presentes em um único cromossomo, poderiam ser usados como marcadores genéticos em estudos de cariotipagem do $T$. cruzi e cstabelecimento de mapas de "linkage".

4.7. Análise das seqüências nucleotidicas e protéicas de B12 e Bl3

4.7.1. Seqüências relacionadas com o gene B 12

Na Figura 12 pode ser vista a sequêencia nucleotidica do gene B12. Na posiçāo 372 inicia-se uma ORF que se estende até a posição 6.714 , onde há um códon de terminação TGA. Com a finalidade de avaliar-se se essa ORF coincide com a predição de uma regiāo supostamente codificadora de proreinas, analisou-se a seqüência nucleotidica no programa CODONPREFERENCE, do pacote de análise de seqüencias GCG (Devereux et al., 1984). Esse programa renta reconhecer seqüências codificadoras de proteinas em virtude da similaridade de seu uso de códons, em comparação com uma tabela de freqüência de utilização de códons. Além disso, esse programa também considera a tendência ("bias") da composição (geralmente GC) na terceira posiçāo de cada códon. A análise é feita individualmente para cada passo de leitura. Os resultados dessa análise (não mostrados) clemonstraram haver um claro aumento na preferência do uso de códons e da tendência GC da terceira posição a partir da posiçāo 450 . Há portanto uma relativa coincidência dessa análise com a ORF prevista pelo ATG da posicão 372 . Um aspecto negarivo da análise da utilização de códons é que ela foi realizada com uma tabela de uso de códons de $E$. coli. Não existe até o momento uma tabela análoga para $T$. cruzi depositada na base de dados CUTG (tabeia de freqüência de códons do GenBank - Wada et al., 1992), em formato 
apropriado para a análise pelo GCG. A tabela do organismo filogeneticamente mais próximo é a de T. brucei (Parsons et al., 1991), no entanto, a utilização de códons para esse parasita é bastante diferente daquela encontrada em T. cruzi (Musto et al., 1994). Embora já tenham sido determinadas tabelas de frequiência de uso de códons para $T$. cruzi (Alonso et al., 1992; Musto et al., 1994), elas não podem ser utilizadas pelo programa CODONPREFERENCE pelo fato dos artigos não apresentarem todas as informaçôes necessárias. Quando estas tabelas estiverem apresentadas no formato adequado, a análise acima poderá ser feita com maior grau de confiabilidade.

Outra análise da seqüência de Bl2 foi feíta com o programa TESTCODE, que também ajuda a identificar seqüências codificadoras de proteinas. Esse programa faz uma análise estatistica da sequêencia em função da não randomicidade da composição de cada terceira base. Seqüências não codificadoras devem apresentar uma maior randomicidade de composição da terceira base do que as codificadoras. Sua vantagem é nāo ter que utilizar tabelas de frequência de códons. No caso do gene B 12 foj observada uma boa correlação entre a predição feita pelo programa e a ORF determinada pela sequencia nucleoridica. (dados não mostrados).

Com relação ao códon de iniciaçào, procedeu-se a uma análisc baseada no modelo de vartedura de Kozak (1989). Segundo esse modelo, a subunidade 405 do ribossomo de eucariotos se ligaria inicialmente à extremidade 5' terminal do mRNA e entāo migraria até atingir u primeiro ATG, posicionado em contexto favorável. A análise de 699 mRNAs de vertebrados (Kozak, 1984, 1989) resulrou na seqüência consenso GCCGCC(A/G)CCAUGGA, relacionada com um contexto favorável de iniciação da traduçāo. A região do suposto códon de iniciação na posição 372 (Figura 12) apresenta a seqüência AGGUUAGUAAUGC. Essa sequiência tem homologia muito baixa com o consenso. Contudo, na seqüência obtida observa-se uma purina $(G)$ na posiçāo -3 , sendo que esse é o nuclcorideo mais conservado em mRNAs de eucariotos, incluindo vertebrados, plantas e fungos (Kozak, 1989). Cavener \& Ray (1991) ampliaram os estudos acerca das sequências flanqueadoras do sitio de iniciaçāo incluindo 112 seqüencias de protozoários. O consenso encontrado foi uuuauaaAAAAUGac (as letras maiúsculas representam os consensos superiores a 50\%), que apresenta homologia ainda menor do que o de Kozak (1989) com o sítio de iniciação de B12. Em relação a essas seqüencias consenso é preciso levar em conta a grande diversidade existente entre os organismos e, mesmo entre os mRNAs de eucariotos superiores, há casos em que a seqüência observada é bastante diferente do consenso proposto (cf. Kozak, 1984). Cavener \& Ray (1991) exemplificam que de um total de 2.595 seqüências de mRNA analisadas, somente $3 \%$ apresentavam o consenso CC(A/G)CCAUGG e 0,2\% o consenso GCCGCC(A/G)CCAUGG. Segundo esses autores, o consenso de Kozak (1989) é estatístico e leva em consideração um nivel máximo de rranscriçăo. Entretanto, nem sempre o nivel máximo é também o nivel ótimo in vivo, ou seja, a predição do códon de iniciaçāo nāo pode 
ser baseada somente em um consenso estatístico, mas também em aspectos funcionais. Em nossa opiniāo, o que torna essa análise problemárica em cucariotos è a falta de conhecimento a respeiro das interaçōes entre o ribossomo e o mRNA. Não existe, por exemplo, a descrição de uma seqüência semelhante à de Shine-Dalgarno, como ocorre em procariotos. Além disso, dadas as peculiaridades dos membros da ordem Kinetoplastida, serão necessários estudos mais específicos em tripanossomatidios para que se possa avaliar a validade do uso dessas seqüências consenso na predição do códon de iniciação.

A existência de uma região rica em pirimidinas a montante ("upstream") do sítio 3. aceptor do mRNA parece ser um fator importante para a eficiência do processo de "transsplicing". Layden \& Eisen (1988) demonstraram em Trypanosoma equiperdum que o "trans. splicing "pode ocorrer em vários sítios, mas os preferenciais seriam aqueles contendo uma regiāo a montante ("upstream") rica em pirimidinas. Além disso, os autores propuseram uma seqüência consenso (5' UACCAAU 3') em mRNAs de nipanossomatidios, a qual seria complementar ao medRNA (RNA doador do mini-exon). Huang \& Van der Ploeg (1991) rambém demonstraram a importância da regiāo de polipirimidinas utilizando um sistema de transfecção transiente e de expressão do gene CAT (cloranfenicol acetil transferase) em $T$. brucei. Foi verificado que a substituição de pirimidinas, especialmente na regiāo -30 a -10 do sítio de "splicing", levava a uma redução drástica da cxpressão de CAT. Esses autores definiram a regiāo de polipirimidina como uma seqüência localizada imediatamente a montante do sítio acepcor de "splicing" (AG), entre as posições -80 e - 1 . Essa região deve conter um mínimo de 5 pirimidinas consecutivas e interrompidas por não mais do que $22 \%$ de purinas. Curotto de Lafaille et al. (1992) demonstraram em Leishmania enrietti que, em rransfecção estável extracromossômica, a produção de mRNA de CAT era dependente de uma regiāo intergênica a montante do gene de cubulina. Essa regiāo podia ser substinuida por um fragmento deletado contendo o sítio de "splícing" e uma região de polipirimidina adjacente, ou mesmo por um fragmento sintético contendo uma regiāo de polipirimidina e um sitio de "splicing".

Recentemente foi verificada uma relação funcional e temporal entre os eventos de "trans-splicing" e poliadenilação de mRNAs. LeBowitz et al. (1993) propuseram em. Leishmania um mecanismo de varredura na seleção do sitio de poliadenilaçāo, assumindo um acoplamento dos processos de "trans-splicing" e poliadenilação. O reconhecimento do sítio aceptor de "splicing" determinaria também o sítio de poliadenilação do mRNA a montante. Matthews et al. (1994) fizeram substituiçōes de blocos na regiāo intergênica entre os cistrons de $\alpha$ - e $\beta$-tubulina e testaram os efeitos utilizando vetores que expressam mRNAs bicistrônicos. Foi verificado que regiões ricas em pirimidinas a montante do sítio 3' de "splicing" do gene de $\alpha$-tubulina são requeridas na identificação desse sítio de "splicing", bem como na seleção do sítio de poliadenilação do gene de ß-tubulina. A remoção dessa regiāo de polipirimidinas pode levar à formação de mRNAs aberrantes com a utilização de 
sítios crípticos de poliadenilaçāo. As regiões de polipirimidinas poderiam ser bifuncionais, atuando em um sistema acoplado de "trans-splicing " e poliadenjlação (LeBowitz et al., 1993) ou serem pontos de ligação para algum fator comum aos dois processos. O possível acoplamento entre esses processos e o papel exercido pela região de polípirimidinas abre uma nova perspectiva para o estudo das regiões intergênicas, conforme salientaram Schürch et al. (1994):

"O achado de que a poliadenilação em mipanossomas é ditacla por seqüências a juzante coloca as regiões intergênicas em uma nova luz. Elas nāo deveriam mais ser consideradas inertes $e_{1}$ portanto, seqüências espaçadoras dispensáveis entre genes adjacentes mas sim, ser exploradas quanto à presença de elementos que podem regular a expressão gênica".

Examinando a seçüência do gene BL2 (Figura 12) observa-se a presença de uma região de polipirimidinas a montante do códon de iniciação, entre as posições 299 e 308 . Essa região é constituída de 10 pirimidinas. Se considerarmos uma regiāo mais extensa, das posiçōes 299 a 328, teríamos um cotal de 30 bases com uma composição de $70 \%$ de pirimidinas. Essas regiōes definiriam dois possiveis sitios aceptores de "splicing" nas posiçōes 317 ou 330. Experimentos de "primer extension" e ensaios de proteção à digestão por Nuclease SI poderiam ajudar a determinar o sírio de "trans-splicing". Outra possibilidade é a realizaçăo de uma reação de PCR em mRNA poti(A*) de $T$. cruzi, utilizando como iniciadores a seqüencia do mini-exon de $T$. cruzi e a seqüència complementar da regiào 5 ' terminal do gene B12. O fragmento resultante poderia ser clonado e seqüenciado, evidenciando a posição do sitio aceptor de "trans-splicing". A seqüência a juzante do códon de terminação do gene B12 apresenta nas posiçōes 6.978 a 6.983 (Figura 12) a seqüência AAUAAA, idêntica à seqüência consenso para sítios de poliadenilaçāo em eucariotos (Proudfoot et al., 1991), embora essa caracteristica não tenha sido definida para T. cruzi (Zwierzynski et al., 1989). Na verdade, conforme foi discutido acima, a definiçāo do sírio de poliadenilaçāo em mipanossomatidios estaria relacionada com a presença de regiões de polipirimidinas a juzante da regiño codificadora. A região intergênica de 812 e Bl 3 apresenta, de fato, 6 regiões de polipírimidinas (ver Figuras 12 e 16).

Um aspecto interessante da seqüência do gene B12 é a existência de 4 blocos com um número variável de repetições seriadas de $60 \mathrm{pb}$ (Figura 12). Nas seqüências já publicadas, incluindo a de um gene homólogo a Bl3 (Buschiazzo er al, 1992), os genes de T. cruzi geralmente apresentam repetições seriadas, mas contidas em um único bloco. Em B12, os blocos de repetiçōes seriadas de 60 pb sāo intercalados por uma seqüência de 519 $\mathrm{pb}$, a qual ocorre de maneira totalmente conservada por três vezes ao longo do gene (Figura 12 - posições 690-1.208; 2.538-3.056; 3.195-3.713). Essa seqüência será denominada repetição maior ou repetição de 173 aminoácidos, quando relacionada à seqüência protéica. 
A presença de vários blocos de repetiçōes seriadas, aliada à existência de dois tipos de reperições no mesmo gene, torna a estrutura do gene $\mathrm{B} 12$ peculiar, principalmente considerando que nāo há homologia entre as seqüências das reperições de 60 pb e de 519 pb. Embora já tenha sido evidenciada a presença de mais de um tipo de repetição em um mesmo gene de Plasmodium, estas repetiçōes apresentam uma alta homologia entre si (Di Giovani et al., 1990). Por outro lado, a proteína KAP de $T$. cruzi (González et al., 1990) apresenta vários blocos de repetições scriadas, que estão separados por pequenos trechos compostos principalmente de repetições degeneradas.

As repetições serjadas de 60 pb não são totalmente conservadas, apresentando microheterogeneidades. Considerando as seqüências do clone Bl2 (Figura l) e de seu respectivo gene (Figura 12) foram observadas mutaçōes em 12 dos 20 códons que compōem cada reperição seriada. Em quatro desses códons foi encontrada mais de uma variação possivel. Do total de 28 variaçōes de códons encontradas, 26 ocorrem por substituiçōes simples e somente três apresentam substituiçōes de 2 bases. Em 16 das 26 variaçōes observadas as mutaçōes ocorrem na rerceira base e não alteram a codificaçāo. Nas 10 mutaçōes em que há substituiçăo do aminoácido, somente + apresentam variaçōes quanto à natureza do grupo radical. Esse resultado indica que, a despeito de uma certa nexibilidade da seqüência nucleotidica, há uma alta conservação das repcriçōes seriadas na estrutura protéica.

Essa estrutura gênjaca altamente repentiva pode ter se originado de eventos sucessivos de recombinação entre dois cromossomos homólogos, em um processo semelhante ao que ocorre na meiose de eucariotos superiores. A origem da primeira duplicação poderia se dar em conseqüência de reajuntamentos erráticos de cromossomos que sofreram quebras em mais de um ponto. A seguir uma sucessão de "crossing-over" desiguais entre cromossomos homólogos poderia levar a um processo dinâmico de aumento ou diminuiçāo do número de repetiçōes (Lewin, 1994; Alberts et al., 1989). Tal comportamento seria bastante semelhante ao verificado em DNA satélite e estaria de acordo com os resultados de Macina et al. (1989), que observaram uma variaçāo do número de repetições seriadas de um mesmo gene entre diferentes cepas de $T$. cruzi, e os de Henriksson et al. (1990), que obtiveram resultados semelhantes comparando dois supostos alelos de um gene homólogo a B13. Outro mecanismo possivel seria o aumento gradativo do número de repetiçōes seriadas por eventos de replicação saltatóna (Lewin, 1994). E possivel que ambos os mecanismos tenham tomado parte no processo evolutivo do gene B12. Nesse caso, eventos de replicação saltatória e/ou "crossing-over" desiguais poderiam ter originado um bloco de repetições de 60 pb adjacente à região da repetição de 519 pb. Em seguida, os blocos de repetições de 60 pb, em conjunto com a repetição de 519 , poderiam ter sido duplicados por um "crossing-over" desigual, gerando domínios alternados de repetiçōes de 60 pb e de 519 pb. 
A estrutura da proceina B12, esquematizada na figura 13, permite verificar a presença de domínios amino- e carboxi-terminais de 36 e 198 aminoácidos, respectivamente. Intemamente há 4 blocos com um número variável de repetiçōes seriadas de 20 aminoácidos, intercalados por 3 reperições de 173 aminoácidos. Conforme discutido acima, as reperiçōes seriadas, a nível protéico sāo bastante conservadas, embora apresentem microheterogeneidades. Por outro lado. as três repetições de 173 aminoácidos são perfeitamente conservadas e, interessantemente, apresentam no seu próprio interior mais duas repetiçōes de 36 aminoácidos com 75\% de identidade. Abaixo está apresentado o alinhamento dessas repetiçōes internas, onde a numeração corresponde às posições relativas em uma escala de 1 a 173 aminoácidos:

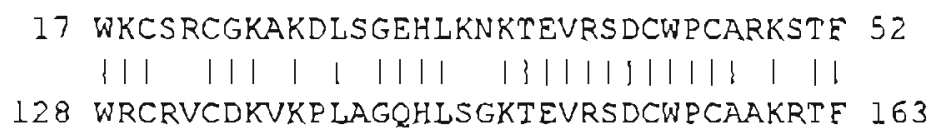

Além desse aspecto interessante, as repetições de 173 aminoácidos apresentam o motivo GQHLSGKT, que é compativel com a seqüência consenso $A$ do sítio de ligação de ATP/GTP (Walker et. al. 1982). Esse motivo, também chamado alça P (Saraste et al., 1990), ć representado pela seqüència $(A, G) \times 4 G K(S, T)$ e está presente em várias proteinas ligantes de GTP e ATP, como quinases, ATP sintase, cadeias pesadas de miosina e quinesina, entre outras. Essa seqüência forma uma alça entre regiões de $\alpha$-hélice e folha $\beta$-pregueada na qual ocorre a interaçāo com um dos grupos fosfato do nucleotidio. Algumas proreínas como quimotripsina, apesar de nāo ligarem-se a um nucleotídio, apresentam esse motivo (Eonte: PROSITE - Dicionário de sitios e padrões de proteinas - versão Outubro 1993). O significado biológico desse achado na protcína B 12 é desconhecido, uma vez que a análise da estrutura secundária, nas regiōes flanqueadoras a esse motivo, demonstrou que esta alça $P$ é flanqueada por uma região de $\alpha$-hélice, mas não de folha $\beta$-pregueada (ver Figura $15 \bar{A}$, posiçāo 270). Além disso, outros sitios relacionados com a ligaçào de adenina ou de guanina dos nucleoridıos, bem como sítios de ligação para os outros fosfatos nāo foram detectados na seqüência de Bi2.

Com relação às repetiçōes seriadas de 20 aminoácidos, há uma alta freqüência de prolinas, que perfazem $20 \%$ da composiçāo de aminoácidos desse dominio. A ocortência de quatro prolinas a cada repetição resulta na formaçâo concomitante de quatro dobras por repetiçāo (ver Figuras 15A e 15B). Como conseqüência, os domínios dessas repetições nào apresentam uma estrutura secundária definida.

Uma questão que surge com relaçăo à estrutura primária de uma grande parte das proteínas de T. cruzi clonadas até hoje diz respeito à ocorrência de repetiçōes seriadas com diferente número de aminoácidos (cf. Frasch et al., 1991). Essa caracteristica estrutural tambėm é observada freqüentemente em proteinas de outros protozoários como $T$, brucei, 
Plasmodium, Leishmania e Toxoplasma. Como caracteristicas comuns essas regiōes apresentam imunodominância e uma alta composição dos aminoácidos $N, A, D, V, P, E, G, Q$ e S e baixa dos aminoácidos C, M, F, W, Y, I e L (Schofield, 1991). Segundo teoria proposta рог este autor, as repetições seriadas poderiam promover ligaçôes cruzadas entre as imunoglobulinas presentes na superfície de células B. Isto representaria um sinal de ativação timo-independente que nāo induziria a maturaçāo de afinidade e conseqüente formação de memória nos linfócitos B e T. Além disso, as reperiçōes reriam uma estrutura primária adequada à formação de epitopos de células $B$, favorecendo a hidrofilicidade e conformação adequadas.

Outro aspecto interessante que pode estar relacionado com as reperiçòes imunodominantes seria sua funçāo putariva de supressão da resposta humoral dirigida contra outros domínios funcionalmente importantes na mesma proteina. Dessa forma, as repetiçōes fariam parte de um mecanismo de evasāo da resposta imune, denominado supressāo epitópica. Os dados obtidos para a enzima trans-sialidase de T. cruzi corroboram esta hipótese. De fato, essa enzima è composta de um dominio amino-terminal que contém os motivos de neuraminidase bacteriana (Cazzulo \& Frasch, 1992) e um domínio carboxiterminal contendo as repetiçóes seriadas previamente caracterizadas no antigeno SAPA (Pollevick et al., 1991\}. Foi demonstrado que anticorpos dirigidos contra as repetições seriadas não reduzem as atividades enzimáticas de trans-sialidase/neuraminidase de $T$. cruzi (Parodi et al., 1992). Alèm disso, enquanto o domínio das repetições (SAPA) è majoritariamente reconhecido por soros de pacientes chagásicos, a regiāo amino-terminal que contém o sitio ativo apresenta uma baixa reatividade (Cazzulo \& Frasch, 1992). Foi também demonstrado que o dominio das reperiçōes não é necessário para a atividade enzimática, uma vez que um gene no qual foi removida a regiăo 3 ' rerminal (codificadora das repetições seriadas) foi capaz de expressar uma enzima ativa com valores cinéticos semelhantes aos da enzima nativa (Campetella et al., 1994).

A seqüência primária da região amino-terminal da proteina $\mathrm{B} 12$ foi analisada quanto à presença de uma seqüência sinal utilizando o programa SIGSEQ, que é baseado no algoritmo de von Hejjne (1986) e seqüencias consenso obtidas a partir de proteínas de procariotos e eucarioros (von Heijne, 1985). Os sítios de clivagem de peptidio sinal sāo caracterizados pela presença de uma região N-terminal básica, um segmento central hidrofóbico e um recho C-terminal polar. Não foi detectada na proteína Bl 2 nenhuma seqüência compativel com a predita para a clivagem do peptidio sinal. A região carboxiterminal da proteina $B 12$, por sua vez, nāo apresentou nenhum segmento hidrofóbico semelhante àqueles detectados em proteínas ligadas a âncoras de glicosil-fosfatidilinositol (Cross, 1990; Ferguson \& Williarns, 1988).

A seqüencia da proteína Bl2 foi analisada pelo programa PEPTIDESTRUCTURE, do pacote de software GCG (Devereux et al., 1984). Esse programa faz prediçōes sobre a 
estrutura secundária de sequiências protéicas pelo método de Chou \& Fasman (1978); hidrofilicidade segundo Kyte \& Doolittle (1982); presença de sítios de glicosilação, entre outras. Os dados calculados por esse programa podem ser utilizados para gerar um gráfico, usando o programa PLOTSTRUCTURE. Conforme explicado no item 3.17.4, a predição foi feita com uma seqüência denominada "Bl2 curta", que apresenta, respectivamente, um dominio amino-terminal, um domínio com 4 repetiçōes de 20 aminoácidos, uma repetição de 173 aminoácidos, um segundo dominio com 4 repetições de 20 aminoácidos e, finalmente, o domínio carboxi-terminal de 198 aminoácidos. Os resultados da predição estāo expostos nas Figuras 15A e 15B. No gráfico de hidrofilicidade se observa que a proteína é predominantemente hidrofílica, embora haja pequenas regiōes hidrofóbicas, especialmente nos domínios da repetiçāo de 173 aminoácidos e carboxiterminal.

A prediçāo de Chou \& Fasman (1978) mostra que nāo há regiōes extensas de estrutura secundária definida, como $\alpha$-hélice ou folha $\beta$-pregueada. Na verdade há uma alternância muito grande entre essas formas de estrutura, gerada principalmente pela grande abundância de prolinas, que provoca uma elevada incidência de dobras. Os dados de predição devem ser interpretados com cautcla, uma vez que a taxa de acertos está ao redor de 50\% (Kabsch \& Sander, 1983) e não existem dados de cristalografia de proteinas semelhantes para serem confrontados. Três prováveis sirios de glicosilação estão indicados na Figura 15A, correspondendo a seqüências Asn-X-Thr/Ser. Quando a posiçào $X$ é ocupada por ácido aspártico, triptofano ou prolina, considera-se um sítio fraco de glicosilação. Em outros casos o sítio apresenta uma maior probabilidade de glicosilação. Os sitios de alta probabilidade aprescrtados correspondem na proteina B12 (Figura 12) às seqüências Asn[le-Thr (posições 24-26), Asn-Lys-Thr (posições 141-143) e Asn-Leu-Ser (posiçōes 184-186). Como esses dois últimos sítios estāo presentes nos 3 dominios da repetição de 173 aminoácidos (ver Figuras 12 e 13), podemos dizer que existe um rotal de sete sítios prováveis de glicosilaçāo na proteína B 12 .

As seqüencias protéicas de "Bl2 curto", assim como de cada um dos domínios isolados, foram utilizadas para uma busca de homologia nos bancos de dados do NCBI. Os domínios amino- e carboxi- terminais nāo apresentaram resultados significativos, embora tivessem sido detectados blocos de homologia com as proteínas quinesina e filamina, respectivamente. O domínio da repetiçāo de 173 aminoácidos apresentou blocos de homologia com integrinas, proteínas ligantes de DNA e a subunidade pesada da proteína triplet de neurofilamento (NF-H) de rato (Chin \& Liem, 1990). As repetiçōes de 60 bp. apresentando $20 \%$ de prolinas em sua composiçāo, apresentaram homologia com proteínas ricas em prolina, entre elas a subunidade pesada da proteina triplet de neurofilamento (NFH) de várias espécies (Chin \& Liem, 1990; Julien et al., 1988), incluindo o homem (Lees et al., 1988); um antigeno de 85 kDa de Babesia bovis (Brown et al, 1993); mucina e proteínas de 
parede celular de Gossypium. As seqüências dessas proteinas foram recuperadas e comparadas com cada um dos domínios de B12 arravés de um gráfico de pontos ("dotplot"). Nào foram observados outros blocos de homologia além dos citados acima.

A proteína de neurofilamento, que foi a única a apresentar blocos de homologia com dois domínios diferentes da proteína Bl2 (Figura 14), apresenta um bloco de repetições seriadas de seis aminácidos (KSPAEA) que, devido à exisfência de uma prolina, apresenra identidades periódicas com as repetições de 60 pb de B12. A homologia é completada com a presença também periódica de residuos de serina e de lisina nas repetiçōes de ambas as proteínas. As sequiências de neurofilamento e de B12 foram comparadas com o programa COMPARE e os resultados plotados pelo programa DOTPLOT (do pacote de programas GCGDevereux et al., 1984), utilizando uma janela de 30 resíduos e uma esrringência de 18 . Os resultados (não mostrados) dernonstraram nāo haver homologia além dos dominios mencionados acima. Esse resultado parece sugerir que a homologia observada ao nivel dos blocos de reperiçōes seriadas das duas proteínas possa năo ter relação funcional e ser casual.

Corroborando essa hipótese, observou-se elevada homologia entre a mesma proteina de neurofilamento c os antigenos 13 (Ibañez et al., 1988) e TcD (Burns et al, 1992), ambos clonados de $T$. cruzi e que apresentam repetições seriadas. Essa comparaçào é mostrada na Figura 25, onde nāo foi incluida a sequiência de Bl2 por apresentar maiores divergências, que prejudicariam o alinhamento múltiplo. A homologia observada entre B12, o antigeno 13 c TCD com a proteína de neurofilamento, embora nāo implique necessariamente em um relacionamento funcional, pode estar associada à induçào de uma reação auto-imune. É interessance ressaltar que em ourro antigeno de $T$. cruzi, denominado Fl-160, foi relatada a existência de um epitopo de 12 aminoácidos que mimetiza uma proteina de nervo dc mamiferos de $48 \mathrm{kDa}$, diferente da proteína de neurofilamento (Van Voorhis et al., 1989; Van Voorhis et al., 1991). Posteriormente foi demonstrado que proteinas da mesma familia multigênica de FL-160 apresentam outro epitopo de reatividade cruzada com nervos, distinto do primeiro (Van Voorhis et al., 1993). Salienta-se que não há homologia entre a seqüência de $B 12$ e Fl-160.

Neste ponto, seria interessante investigar se o antigeno B12 apresenta reatividade cruzada com neurofilamento. Pretende-se no futuro testar se um soro anti-Bl 2 reage com nervos de mamiferos em cortes histológicos e em Western blot. Se os resultados forem positivos, poderá ser feito um mapeamento de epitopos segundo o sistema preconizado por Geysen et al. (1987), onde utilizam-se peprídios sintéticos de cerca de 8 resíduos que, sobrepostos, cobrem uma região determinada da proteína. Em ensaios de competição entre os anticorpos e os peptídios frente à proteina, é possível identificar os epitopos de reatividade cruzada. Particularmente com B12, seria interessante testar soros de pacientes chagásicos que apresentam degenerações nervosas, como ocorre nos casos de neuropatia, 


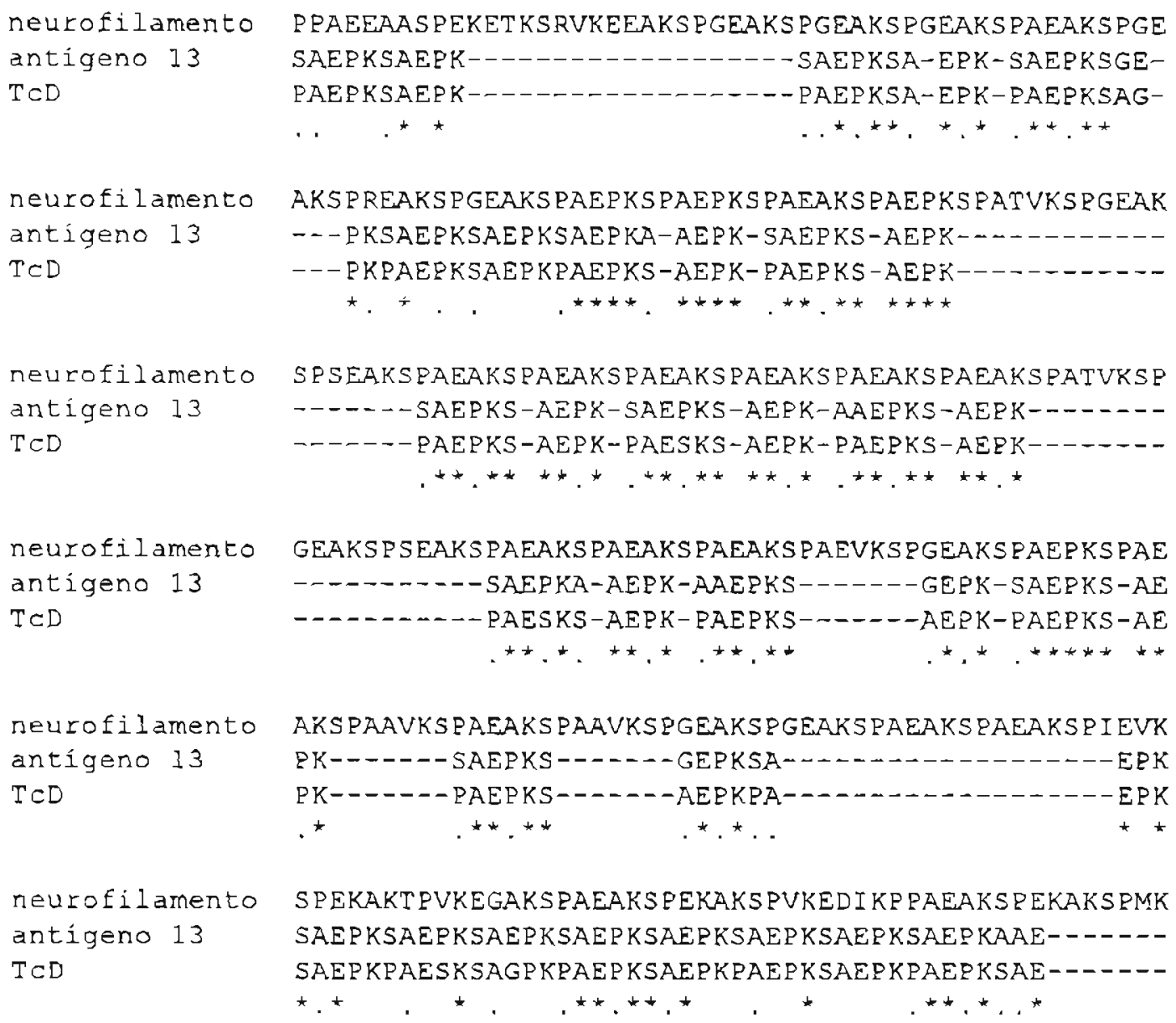

PPAEEAASPEKETKSRVKEEAKSPGEAKSPGEAKSPGEAKSPAEAKSPGE SAEPKSAEPK----------------- SAEPKSA-EPK-SAEPKSGEPAEPKSAEPK----------------PAEPKSA-EPK-PAEPKSAG$\ldots \ldots .^{\star} \ldots \ldots^{\star \star}, \star^{\star}, \ldots^{\star}+\star$

AKSPREAKSPGEAKS PAEPKSPAEPKS PAEAKSPAEPKSPATVKSPGEAK

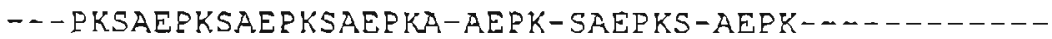

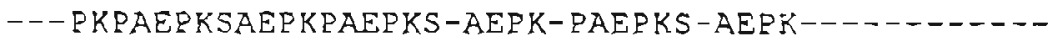

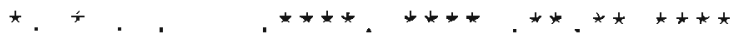

SPSEAKSPAEAKS PAEAKSPAEAKSPAEAKSPAEAKSPAEAKSPATVKSP --..-SAEPKS-AEPK-SAEPKS-AEPK-AAEPKS-AEPK-..-.$\cdots-\cdots-$ PAEPKS-AEPK-PAESKS-AEPK-PAEPKS-AEEK---.--

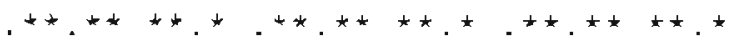

GEAKSPSEAKSPAEAKSPAEAKSPAEAKSPAEVKS PGEAKSPAEPKSPAE - - - - SAEEKA-AEPK-AAEPKS-----GEPK-SAEPKS-AE - . . . - PAESKS-AEPK-PAEPKS- - - AEPK-PAEPKS-A.E

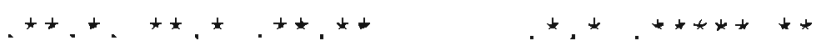

AKS PAAVKSPAEAKS PAAVKSPGEAKSPGEAKSPAEAKS QAEAKS P IEVK

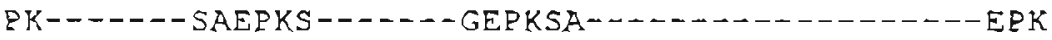

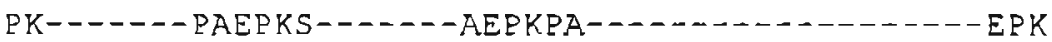

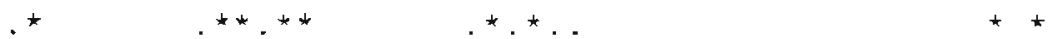

SPEKAKT PVKEGAKSPAEAKSPEKAKSPVKEDI KP PAEAKSPEKAKSPMK SAEPKSAEPKSAEPKSAEPKSAEPKSAEPKSAEPKSAEPKAAE---- - SAEPKPAESKSAGPKPAEPKSAEPKPAEPKSAEPKPAEPKSAE------

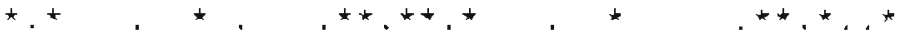

Figura 25 - Alinhamento múltiplo, abtido pelo programa Clustal $V$, entre as seqüências parciais das proteínas de neurofilamento miplet $H$ de rato (PIR - A37221), antigeno 13 (GenBank - M92046) e TcD (GenBank - M82834). Os húfens representam lacunas entre as seqüências alinhadas. Os símbolos abaixo das seqüências representam resíduos idênticos nas três seqüências ( ${ }^{*}$ ) ou somente em duas ( . ). 
cardiomiopatia, e nas megasíndromes digestivas. A busca e identificação de epitopos de reatividade cruzada entre $B 12$ e neurofilamento deverá ser investigada no futuro.

Uma análise similar, realizada entre a proteína B13 e a cadeia pesada de miosina cardíaca humana, demonstrou a existência de um epitopo de reatividade cruzada entre as duas proteínas. Esse epitopo, caracterizado pela seqüência AAALDK na miosina e AAAGDK em B13, é reconhecido majoritariamente por soros de pacientes chagásicos cardiopatas (Cunha-Neto, 1994; Cunha-Neto et al., 1994). o mimetismo antigênico é um aspecto importante na doença de Chagas, que pode estar relacionado com a indução da patogênese resultante de processos autoimuncs.

\subsubsection{Seqüências relacionadas com o gene B13}

No item anterior foi discutida a análise da scqüência do gene B12, obtida entre os sítios H3 e B4 (consultar Figura 8) e que inclui uma parte da região intergênica entre Bl2 e B13. A seqüência do fragmento B4H5, que representa a continuaçāo dessa região intergênica e a porção $S^{\prime}$ terminal do gene Bl3, pode ser visualizada na Figura 16 . Em virtude de ter sido previamente descrita a seqüência completa de um gene homólogo a Bl3 (Buschiazzo et al., 1992), decidiu-se nāo determinar a seqüência nucleotidica da porçào 3' do gene Bl3.

Na posição 544 da região intergênica (Figura 16), existe um códon de terminação TAG, a partir do qual existe um passo de leitura aberto ao longo do fragmento, com possiveis códons de iniciação nas posições 553,556, 610,613 e 829. O clone TcCA-2 (Buschiazzo et al. 1992), homólogo a Bl3, apresenta um códon de iniciação equivalente àquele da posição 829 . Entretanto, 73 pb a montante, existe um códon de terminação que inviabiliza os demais códons ATG como sítios de iniciaçāo. Comparando nossa seqüência com a do clone Tc-CA-2 observa-se uma homologia de 95,5\% (Eigura 17). Entretanto, a existência de 7 regiōes de lacunas entre as duas seqüências faz com que, no clone TcCA-2, os ATGs das posiçōes 553, 556, 610613 estejam em outro passo de leitura. Essa discrepância entre as duas seqüências provavelmente se deve às diferentes cepas de $T$. cruzi utilizadas (Y e CA-1). Não sabemos se, no caso do gene B13, os códons a montante do ATG da posição 829 seriam funcionais.

Temos entretanto alguns resultados que, indiretamente, parecem indicar que o sitio de iniciação mais provável seja o da posição 829, mesmo no caso do gene B13. Em primeiro lugar, se admitirmos a funcionalidade dos demais códons de iniciação, teríamos um domínio adicional de cerca de 70 a 90 aminoácidos na proteína Bl3 em relação àquela caracterizada por Buschiazzo et al. (1992). Esse dominio seria extremamente hidrofóbico, contendo longos trechos compostos somente de fenjlalaninas, uma vez que esta região do gene é muito rica em timinas. Utilizando os programas CODONPREFERENCE e TESTCODE, 
concluiu-se que a probabilidade da regiāo a montante do códon da posiçāo 829 ser codificante seria baixa (dados não mostrados). Além disso, o segmento compreendido entre as posiçōes 684 a 7.54 é muito rico em pirimidinas e define dois possivveis sitios aceptores de "trans-splicing", nas posições 756 e 761 . Como já foi discutido anteriormente, a região de polipirimidina a montante do sitio 3' aceptor é importante para o processo de "trans. splicing "(Huang \& Van der Ploeg, 1991). Os códons das posições 610 e 613 , por outro lado, não apresentam a montante nenhuma regiāo próxima de polipirimidinás. Já os códons 553 e 554 estăo mais próximos de um trecho de pirimidinas ( 464 a 482).

Outro aspecto interessante quando se alinham as seqüencias do fragmento B4H5 e do clone TCCA-2 diz respeito às lacunas. Observando a Figura 17, verifica-se que todas as lacunas entre as duas seqüèncias ocorrem a montante do códon 829 , sendo que quatro delas na região entre as posições 553 e 829. Como essas lacunas alteram o passo de leitura, esse fato sugere que essa regiào não seria codificadora e, portanto, não estaria sob pressão evolutiva. Por outro lado, a juzante da posição 829 somente são encontradas mutaçóes pontuais de substituiçăo, sem alteração do passo de leitura, sugerindo uma maior pressāo cvolutiva. Obviamente todas as caracteristicas apontadas acima não excluem totalmente a possibilidade de os códons a montante da posição 829 serem funcionais. Ensaios de "primer-extension" e de proteção à digestāo por nuclease Sl poderiam ajudar a elucidar esse aspecto.

A regiāo do suposto códon de iniciação da posição 829 apresenta a sequência AUAAAUAUGGC. Essa seqüència contém, alèm de uma purina (A) na posiçāo -3, uma guanina na posiçāo +4 que, segundo Kozak (1989), também é importante para o início da tradução. Esse sítio de iniciação também apresenta uma homologia com o a sequiencia consenso uuuauaaAAAAUGac de Cavener \& Ray (1991).

As repetições seriadas de B13 (Figura 1), assim como as de B12, apresentam uma alta composição de prolinas, aringindo até três residuos por repetiçāo (25\%). Essa alta porcentagem de prolinas gera uma estrutura retorcida com alta incidência de dobras (dados nāo mostrados). A seqüência relatada por Buschiazzo et al. (1992) para o clone TcCA-2 (homólogo a B13) não mostra a presença de sítios de clivagem de pepridio sinal ou de ancoragem de estruturas de glicosil-fosfatidilinositol. Buscas em bancos de dados, realizadas com a sequiência protéica de Bl3, e com a seqüência completa relatada por Buschiazzo et al. (1992), não resultaram em nenhuma proteína com homologia signifícativa.

\subsection{Caracterização do gene B 11 e sua relação com retrotransposons}

A determinação do mapa de transcrição da região de $32 \mathrm{~kb}$ permitiu identificar um terceiro cistron, denominado Bl l, disrante cerca de $9,5 \mathrm{~kb}$ do gene Bl2. Uma sonda feita a partir do fragmento SEl (Figura 8) hibridizou com um rranscrito de $5.5 \mathrm{~kb}$ em ensaios de 
Northem blot feitos com RNA rotal (Figura 18) e fraçăo poli (A) ${ }^{+}$de formas epimastigotas (dados nāo mostrados). Futuramente essa anàise deverá ser estendida a RNA de tripomastigotas. Foi verificada também uma fraca hibridizaçăo com bandas de RNA de alto peso molecular. Esse resultado pode ser atribuido à possível existência de ranscritos policistrônicos ou entāo ser devido a uma hibridizaçāo inespecífica.

O gene Bll apresenta um grande número de cópias por genoma, conforme verificado em ensaio de Southern blot (Figura 19). Nessa figura é possivel visualizar a presença de múltiplas bandas na maior parte das digestões. Algumas bandas, entretanto, são muito mais intensas e podem representar cópias altamente conservadas, enquanto que as demais representariam cópias contendo polimorfismos nos seus sitios de restriçāo. É interessante notar que as cópias de B I I não apresentam polimorfismo para a enzima Sacll, pois somente se observa a hibridizaçāo de alta intesidade com uma única banda. A existência de bandas de alta intensidade de hibridizaçāo também poderia levar à interpretação de que a maior parte das cópias estivesse arranjada em série. Nesse caso, as bandas fracas corresponderiam a algumas cópias dispersas no genoma do parasita, ou seja, "orphons" (Childs et al., 1981). Entretanto, os dados de Southern blot de um gel de campo pulsado não são totalmente compativeis com essa hipótese. Conforme se observa na Figura 24, a sonda SEl hibridiza com a quase totalidade dos cromossomos distingüiveis no gel, em todas as cepas testadas ( $C L, Y$ e G). A existência de hibridizaçōes mais intensas em alguns cromossomos, especialmente nas cepas $Y$ e G, sugere que eles podem conter blocos de cópias seriadas desse gene. Entretanto, uma grande proporção das cópias de B 11 também estaria dispersa nos demais cromossomos.

Usando o programa FRAMES, que mostra as "open reading frames" (ORFs) nos 6 passos de leitura possiveis, identificou-se uma ORF ao longo de todo o fragmento SEl na orientação EcoRI $\rightarrow$ Sall (dados nāo mostrados). A direção da transcrição dessa hipotérica ORF seria oposta à dos genes B12 c Bl3 (ver figura 8). A análise com o programa TESTCODE confirmou a existência de uma maior probabilidade de codificação nessa orientaçāo do fragmento. A seqüência completa do fragmento SEl c da suposta ORF estão apresentadas na Figura 20. A análise da seqüència proréica de B1 l pelo programa PEPTIDESTRUCTURE demonstrou a existência de uma seqüência Asn-Val-Ser (posiçōes 43-45), companive) com um sítio de glicosilaçăo. Além disso há uma predominância de blocos de estrutura secundária do tipo folha $\beta$-pregueada alternados com dobras (Figura 23).

Quando essa sequiencia protéica foi comparada com o banco de dados GenBank, foram observados vários blocos de homologia com o produto protéico da ORFl de TRS-1, um elemento com caracteristicas de retrotransposon, isolado de T. brucei (Murphy et al., 1987). As seqüências protéicas de SEl e TRS-I foram então alinhadas com o programa BESTFIT, obtendo-se cerca de $30 \%$ de identidade e uma homologia de $48 \%$ em um total de 252 resíduos de aminoácidos (Figura 21 ). Quando as respectivas seqüências nucleotídicas 
foram alinhadas obteve-se uma homologia de 43\% (Figura 22). A comparação dos perfis de hidropaticidade das proteinas de SEI e TRS-l demonstrou semelhanças (dados não mostrados), sugerindo que a homologia observada a nivel da estrutura primária das proteínas pode ter também um significado funcional. A proteína codificada pela ORF-1 de TRS-l apresenta homologia com transcriptases reversas (Murphy et al., 1987). Quando a seqüência da proteina foi comparada com o banco de dados PROSITE, nenhum sítio ou padrāo específico foi identificado. Vale ressaltar que essa seqüência, quando comparada à de TRS-1, não abrange o sítio ativo da transcriptase reversa, que é a região mais conservada. Esse fato explica porque não se encontrou em SEI um motivo relacionado com essa enzima. A existência de retrotransposons em membros da ordem Kinecoplastida têm sido demonstrada desde o ínicio da década 80 (ver Tabela i]). Os retrotransposons ou retroposons são elementos não infecciosos de DNA que têm aspectos estruturais (homologia com transcriptases reversas virais) que sugerem que sua transposição ocorra via um intermediário de RNA (cf. Boeke \& Corces, 1989). A maior parte dos elementos descritos em Kinetoplastida, incluindo o TRS-1, apresenca caracteristicas estrutural e filogeneticamente semelhantes aos LINEs - Long Interspersed Elements (para revisões consultar: Singer, 1982; Singer \& Skowronski, 1985; Fanning \& Singer, 1987) descritos em mamiferos (Xiong \& Ejckbush, 1090). Esses retroposons têm com uma de suas principais características a ausência de LTRs ("long terminal repeats") em suas extremidades.

O elemento TRS-1 (Murphy et al., 1987) apresenta 5,2 kb e é flanqueado em suas extremidades por duas merades de um ourro retrotransposon denominado RIME, o qual greralmente está relacionado com genes ribossomais (Hasan et al, 1984). Um elemento análogo a TRS.1 foi também descrito independentemente por Kimmel et al. (1987) e denominado "ingi", como referência a um adjetivo de uma língua africana Kiswahili, que siginifica "muito". O produto protéico da ORFl é um polipeptidio de 1651 aminoácidos que apresenta em sua porçăo carboxi-terminal um dominio contendo cinco motivos de "zincfingers" (Pays \& Murphy, 1987), que representa a região de ligação com o ácido nucléico (Ḱlug \& Rhodes, 1987). Ao contrário dos elementos denominados "siteposons" (Aksoy, 1991), TRS-1/ingi estāo dispersos no genoma de $T$. brucei e não apresentam sítios específicos de inserção. Os "siteposons" constituem uma familia de retroposons isolados em T. brucei (elemento MAE - Carrington et al., 1987), T. gambiense (elemento SLACS - Aksoy, 1987; Aksoy, 1991), Crithidia fasciculata (elemento CREl - Gabriel et al, 1990) e T. cruzi (elemento CZAR - Villanueva et al., 1991). Alem de apresentarem homologias em suas seqüências, têm como principal caracteristica comum a inserção sítio-especifica entre os nucleotídios 11 e 12 de genes de SL-RNA (Aksoy, 1993). O elemento CREl aparentemente é ativo, uma vez que verificou-se uma alta taxa de rearranjo, atingindo $1 \%$ a cada geração (Gabriel et al., 1990). Interesantemente os "siteposons" estāo ausentes nas amostras de 
TABELA 11 - Comparação das características dos diferentes elementos do tipo retrotransposons isolados de organismos da ordem Kinetoplastida.

\begin{tabular}{|c|c|c|c|c|c|c|}
\hline $\begin{array}{l}\text { Nome do } \\
\text { elemento }\end{array}$ & Organismo & Tamanho & $\begin{array}{l}\mathrm{N}^{\circ} \text { de copias/ } \\
\text { genona haploide }\end{array}$ & Outros elementos relacionados & Comentários & Referència \\
\hline RIME & T. brucei & $\begin{array}{l}\text { dimeros de } \\
\text { sll bases }\end{array}$ & 200 & $\begin{array}{l}\text { Cópias de RIME sāo encontradas } \\
\text { associadas com TRS.1//ngi. }\end{array}$ & Inserido em genes de rRNA & Hasan ef $a t, 1984$ \\
\hline TRS-1 & T. brucel & $5,2 \mathrm{~kb}$ & 200 & Possivelmente igual ao Ingi. & 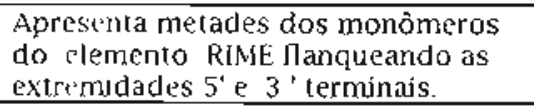 & Nurphy et al. 1987 \\
\hline Ingi & T. bruce & $5,2 \mathrm{~kb}$ & 200 & Possivelmente igual ao TRS-l. & $\begin{array}{l}\text { Apresenta metades dos monômeros } \\
\text { do elemento RlME nas extremudades } \\
5 \text { 'e } 3 \text { ' terminas. }\end{array}$ & Kimmel er al, 1987 \\
\hline TUBis & T. bracel & $\begin{array}{l}4,0 \mathrm{~kb} \\
\text { (truncado }\end{array}$ & $\begin{array}{l}\text { Poucas cópias em } \\
\text { uma localização } \\
\text { cromossônmica }\end{array}$ & $\begin{array}{l}\text { Representa uma forma truncada } \\
\text { de elemento TRS-1/Ingi Conréril } \\
\text { trechos de RJME. }\end{array}$ & $\begin{array}{l}\text { Inserido na extremdade } 3^{\prime} \text { teminal } \\
\text { do ùltimo gene de } \beta \text { - } 4 \text { bulına do } \\
\text { bloco de genes seriados. }\end{array}$ & $\begin{array}{l}\text { Affolter et al, } 1989 ; \\
\text { Clauser et al, } 1994\end{array}$ \\
\hline ESR & T. brucel & $1,4 / 2,0 \mathrm{~kb}$ & $12-18$ & $\begin{array}{l}\text { Homologia de } 52 \% \text { com TRS- } 1 / \\
\text { Ingi. }\end{array}$ & $\begin{array}{l}\text { Pseudogene inserido a monlante do } \\
\text { promoror do sitio de espressăo T3 e } \\
\text { T5 de genes de vSG . }\end{array}$ & $\begin{array}{l}\text { Smiley er al, } 1990 \\
\text { Lodes et aL, } 1993\end{array}$ \\
\hline CREl & C. Fasciculata & $4,0 \mathrm{~kb}$ & 10 & $\begin{array}{l}\text { Relacionado com SLACS, CZAR e } \\
\text { MAE. }\end{array}$ & $\begin{array}{l}\text { Inserido em genes de SL-RNA } \\
\text { Transposiça sitio-especifica. } \\
\text { slleposon }\end{array}$ & Gabriel et aL, 1990 \\
\hline CZAR & T. cruai & $7,3 \mathrm{~kb}$ & $15-20$ & $\begin{array}{l}\text { Relacionado a CREl, SLACS e } \\
\text { MAE }\end{array}$ & $\begin{array}{l}\text { Inserido en genes de SL-RNA } \\
\text { Transposicano sitlo-especifica } \\
\text { siteposon }\end{array}$ & $\begin{array}{l}\text { Villanueva et } a l, \\
199 !\end{array}$ \\
\hline SLACS & T. gambiense & $7, \overline{0 \mathrm{~kb}}$ & 8 & $\begin{array}{l}\text { Possivelmente igual ao MAEe } \\
\text { relacionado com CZAR e CREI. }\end{array}$ & $\begin{array}{l}\text { Inserido em genes de SL-RNA } \\
\text { Transposicăo sitto-especifica. } \\
\text { stteposon }\end{array}$ & Aksoy et al, 1987 \\
\hline MAE & T. brucei & $5,5-7 \mathrm{~kb}$ & 25 & $\begin{array}{l}\text { Possiveimente igual ao SLACS e } \\
\text { relacionado com CZAR e CRE }\end{array}$ & $\begin{array}{l}\text { Inserido em genes de SL-RNA } \\
\text { Transposição sitlo-especifica. } \\
\text { siteposon. }\end{array}$ & $\begin{array}{l}\text { Carrington el at. } \\
1987\end{array}$ \\
\hline Sem nome & T. cruzi & $\begin{array}{l}317 \mathrm{pb} \\
\text { (truncado) }\end{array}$ & $\begin{array}{l}\text { Baixo (nāo } \\
\text { determinado) }\end{array}$ & $\begin{array}{l}\text { Extremidade } 5 \text { terminal } \\
\text { semelhante à posição } \\
\text { correspondente em RIMIE }\end{array}$ & $\begin{array}{l}\text { Inserido na regiazo intergênja de } \\
\text { genes seriados de gGAPDH }\end{array}$ & Kendall er al. 1990 \\
\hline Sem nome & T. cruzi & $\begin{array}{l}182 \mathrm{pb} \\
\text { (truncado") }\end{array}$ & $\begin{array}{l}50-89 \text { copias do gene } \\
\text { TAT . Näo medido } \\
\text { especificamente para } \\
\text { o elemento. }\end{array}$ & Hontologia de $77 \%$ com RINE. & $\begin{array}{l}\text { Inserido na regtâo intergêtndca de } \\
\text { genes seriados de TAT }\end{array}$ & Bontempi el $a l . \overline{1993}$ \\
\hline
\end{tabular}

"O elemento identificado está truncado por um gene associado

*m gGAPDH - gliceraldeido-3-P desidrogenase glicossomal

* w TAT - tirosina aminotransferase 
Leishmania testadas, sugerindo que este gênero pode ter surgido antes da introdução desses elementos (Aksoy, 1993). A construçāo de um gene quimérico da ORF do elemento CREl com o retrotransposon Tyl permitiu observar em leveduras a expressão de uma atividade de DNA polimerase RNA-dirigida, indicando que esse elemento codifica uma transcriptase reversa funcionalmente ativa (Gabriel \& Boeke, 1991), enzima requerida no evento de retrotransposição.

Alguns elementos apresentando homologia com retrotransposons, porém truncados pelos genes vizinhos também foram observados. Uma seqüência homóloga a TRS-1/ingi, deominada TUBIS, foi identificada na regiāo $3^{\prime}$ rerminal do último gene de $\beta$-rubulina do bloco de genes seriados de $T$. brucei (Affolter, 1989). A inserçāo deste elemento provocou a interrupção do último gene de $\beta$-tubulina, gerando um pseudogene. O elemento TuBIS por

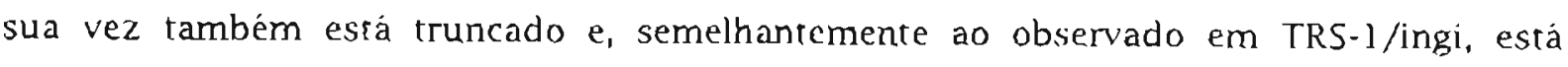
associado à seqüência RIME. Uma hipótese è de que TUBIS represente um vestigio fossilizado da inserção de um elemento TRS-1/ingi no bloco de genes de rubulina (Glauser \& Braun, 1994). Uma vez que TUBIS está presente em varias espécies do subgênero Trypanozoon e na mesma localizaçăo cromossômica, mas nāo em $T$. congolense e $T$. cruzi, sugere-se que esta inserção teria ocorrido somente após a ramificação das seções Stercoraria e Salivaria, bem como dos subgêneros Trypanozoon e Nannomonas (Braun et al., 1992).

Outros elementos truncados também foram identificados na regiăo intergênica de genes seriados de gliceraldeído 3-P desidrogenase glicossomal (Kendall et al., 1990) e tirosina aminotransferase (Bontempi et al., 1993) de $T$. cruzi. Um elemento relacionado com Ingi, denominado ESR, também foi encontrado inserido em regiōes 5 ' terminais de genes dc VSG de T. brucei, (Smiley et al., 1990; Lodes et al., 1993). Embora ESR seja transcrito, dados de seqüenciamento indicaram que não há códons de iniciação, caracterizando-o como um pseudogene. O local de inserção está a cerca de 30 pb do suposto promotor dos sítios de expressão T3 e TS, e o elemento está posicionado em uma orientação invertida em relaçāo aos genes de VSG. Uma vez que ESR apresenta acumulação de transcritos em formas sanguíneas mas não em prociclicas, e está inserido em sítios de expressão de genes de VSG. sugere-se que sua expressăo possa estar coordenada com a desses genes (Lodes et al., 1993).

Visando caracterizar melhor o gene Bll, foi construida uma biblioteca genômica parcial de $T$. cruzi, contendo fragmentos genômicos de EcoRl, de tamanho entre 3,5 a 5,5 kb. Usando o inserto SEl como sonda, foram isolados alguns clones homólogos. Um deles, denominado 5.3 apresenta $5,3 \mathrm{~kb}$ e está sendo seqüenciado em nosso laboratório. Esse trabalho está sendo conduzido por Beatriz Simonsen Stolf em seu estágio de iniciação cientifica. 
Recentemente, na XXI Reunião Anual de Pesquisa Básica sobre Doença de Chagas, foi comunicada a clonagem e caracterizaçào de um retrotransposon de $T$. cruzi com caracteristicas muito simulares a Bll (Francisco Martin - Instituto de Parasitologia y Biomedicina, Granada, Espanha). Este elemento, denominado LlTc, apresenta 5,3 kb, é transcrito somente em formas replicativas amastigotas e epimastigotas, mas nāo em tripomastigotas, apresenta homologia com TRS-I/Ingi e codifica para uma transcriptase reversa e uma endonuclease. A comparaçào das seqüências nucleotídica e protéica de LlTc e $B l 1$ revelou que ambos os elementos são virtualmente idênticos. O retrotransposon LITc apresenta em sua porção 3' rerminal homologia com o elemento El2, previamente descrito pelo mesmo grupo (Requena et al., 1994).

\subsection{Perspectivas futuras}

Neste trabalho foram relatadas a clonagem e caracterização de dois genes connguos de T. cruzi, codificadores de antigenos. O gene Bl 2 foi totalmente sequienciado e, a partir da seqüência protéica, foi possivel evidenciar a presença de blocos com cerra homologia com uma proreína de nervos de mamiferos: a subunidade pesada de neurofilamento. A existência de possiveis epitopos de reatividade cruzada entre estas duas proteínas deverá ser investigada, semelhantemente ao que foi realizado para a proteína B13 e miosina cardiaca humana (Cunha-Neto, 1994; Cunha-Neto et al., 1994). Com relaçāo à propria proteina $\mathrm{B} 13$, os trabalhos de investigação de seu papel na autoirnunidade e patogénese deverá ser continuado por Márcia Duranti, estudante de doutorado, em colaboração com o grupo do Dr. Jorge Kalil, do Instituto do Coração.

O fato de B12 e B 13 serem genes contíguos abre a possibilidade de compartilharem um transcrito comum policistrônico. Embora nossos resultados nāo renham demonstrado sua existència, pretende-se realizar experimentos de "nu-on", para confirmar essa hipótese.

Outra caracteristica ainda nāo analisada dos transcritos de Bl2 e B13 diz respeito aos sitios de "trans-splicing". Pretende-se investigar esse aspecto através da clonagem e seqüenciamento das extremidades $5^{\prime}$ terminais dos mRNAs via RACE.PCR, utilizando como iniciadores a seqüência do mini-exon e oligonucleoridios de regiōes da fita complementar a juzante. Também deverão ser feitos ensaios concomitantes de proteção à digestão com nuclease S1 e "primer-extension". Esta última técnica poderá evidenciar a existência de sítios alternativos e hierárquicos de "trans-splicing", como foi previamente demonstrado (Revelard et al., 1993).

A localização dos sítios de poliadenilação dos transcritos de Bl2 e Bl3 também deverá ser investigada. Pretende-se utilizar as regiōes 3' terminais dos respectivos genes para a varredura de uma biblioteca de cDNA de T. cruzi, com o intuito de isolar clones contendo a cauda poliadenilada. Esses clones deverão ser seqüenciados e os dados serăo 
comparados com as seqüências genômicas que já dispomos, visando identificar a localização dos sítios de adição da cauda poli (A)+.

Visando identificar possiveis sequiências regulatórias de transcriçāo, as regiōes a montante do gene Bl2 e intergênica, entre 812 e Bl3, deverão ser inseridas em vetores contendo genes-repórter. Estas construções, seguidas por uma transfeccão e expressão transiente, poderāo indicar a presença de promotores, bem como de sítios funcionais de trans-splicing e poliadenilação. Com o objetivo de investigar a funçāo dos genes B12 e B13 na biologia do parasita, deverão ser conduzidos experimentos de ruptura gênica por recombinação homóloga. Para essa tarefa serão construídos vetores contendo genes de resistência a neomicina e/ou higromicina, tlanqueados das regiōes a montante e a juzante dos genes Bl2 e Bl3.

O fato de termos isolado dois genes distintos e contiguos abre a possibilidade de estudar a conservacão deste "linkage" nas diferentes cepas de T. cruzi. Este estudo pode ser interessante nāo somente para detectar relaçòes taxonômicas entre cepas, como também para verificar o grau de rearranjos genómicos em populaçōes do parasita. Além disto, o programa de seqüenciamentn do genoma de $\Gamma$. cruzi terá como primeira etapa o mapeamento físico dos cromossomos (Levin et al, 1994). As sondas de Bl2 e Bl3, que sāo genes de cópia unica, poderăo ser úteis tanto na identificação do cromossomo a que pertencem, como também no seu mapeamento.

O gene B11, identificado como um retrotransposon da familia dos elementos LINEs (Fanning \& Singer, 1987), poderá ser utilizado como um marcador de, senão todos, ao menos da quase totalidade dos cromossomos de $T$. cruzi. Além disto, como este elemento c/ou retroposons homólogos estão presentes tanto em membros da seção Stercoraria como Salivaria, ele abre a possibilidade de esrudos filogenéticos baseados em sua seqüência e distribuição. Aém disso, como este elemento está altamente disperso no genoma do parasita, é possivel que possa ser utilizado em estudos de RFLP ("restriction fragments length polymorphism"), visando a identificação e classificaçāo de cepas de T. cruzi.

Finalmente, a observação de que o soro anti-GST Schistosoma japonicum reage com proteínas de $T$. cruzi sugere seu uso na cionagem da GST de $T$. cruzi. Um dado interessante é que proteínas de $T$. cruzi purificadas por cromatografia de afinidade em colunas de GSHagarose foram reconhecidas pelo soro anti-GST. De fato, em um trabalho paralelo, desenvolvido em nosso laboratório, esse soro foi utilizado para a varredura de uma biblioteca genômica de $T$, cruzi em $\lambda$ gtll. Foram isolados três clones, os quais estāo sendo caracterizados. Um deles, denominado 1.1, foi subclonado no vetor pEX34b (Klinkert et al., 1988) e expresso em fusão com a polimerase do fago MS2 . A proteína de fusāo também foi reconhecida pelo soro anti-GST. Esse trabalho de clonagem e caracterizaçāo de genes de proteínas relacionadas com o metabolismo de glutationa está sendo continuado pelo estudante de doutoramento Fernando Freitas em nosso laboratório. 


\section{RESUMO}

Uma biblioteca genômica de $T$. cruzi, construida no vetor $\lambda$ gr 11, foi selecionada com um soro anti-tripomastigota. Dois clones, denominados Bl2 e B13, foram isolados, verificando-se que expressam proteínas que contém repetições seriadas de 20 aminoácidos (B12) e 12 aminoácidos (B13). Os insertos respectivos foram subclonados e expressos em fusāo com $\beta$-galactosidase no vetor pNSgt ll. A caracterizaçāo dos antígenos em $T$. cruzi foi feita por Western blot, utilizando soros de coelho contra as proteinas de fusão ou anticorpos imuno-selecionados de soros de pacientes chagásicos. Concluiu-se que Bl2 corresponde a antígenos de $230 \mathrm{kDa}$ e $200 \mathrm{kDa}$ expressos em tripomastigotas e epimastigotas, respectivamente. Anticorpos contra B13 reconheceram antigenos de $140 \mathrm{kDa}$ e $116 \mathrm{kDa}$ nas duas formas evolutivas. A imunoprecipitaçāo de parasitas radioiodados indicou que o antígeno de $140 \mathrm{kDa}$ está localizado na superfície de tripomastigotas, enquanto os demais polipeptídios correspondem a antigenos internos em ambos os estágios evolutivos. As proteínas recombinantes 812 e $\mathrm{B} 13$ foram avaliadas no diagnóstico sorológico da doença de Chagas por radioimunoensaio. Foi feito um levantamento com 128 soros, sendo 70 de paciences chagásicos, 38 de pacientes com outras parasitoses e 20 de individuos normais. Bl2 e Bl3 obtiveram indices Kappa, que estimam a proporção de acertos verdadeiros, de 0,94 e 0,61 , respectivamente. Esses resultados indicam que o antigeno Bl3 é um candidato potencial para ser empregado no diagnóstico sorológico da doença de Chagas.

Os insertos dos clones B 12 e B 13 foram usados como sondas para o isolamento de clones genômicos de uma biblioreca em $\lambda$ EMBL3. O mapa de restriçāo de uma regiāo de 32 $\mathrm{kb}$ do genoma de $T$. cruzi indicou que os genes B12 e Bl3 sāo contiguos. Em ensaios de Northerm blot B12 hibridizou com transcritos de 7,2 e $8,8 \mathrm{~kb}$ e Bl 3 com mRNAs de 3,5 e 4,2 kb. O arranjo genômico de Bl2 e Bl3, deduzido de Southern blors de DNA e de cromossomos separados por elerroforese de campo pulsado, é compativel com genes de cópia única. A seqüência completa de um gene homólogo a B13 foi previamente descrita por Buschiazzo e cols. (Mol. Biochem. Parasitol, 54: 125-128, 1992), indicando que 75 repetições seriadas de 36 pb estão presentes em um único bloco. A seqüência complera do gene Bl2 e da regiāo intergênica entre Bl2 e Bl3 foi determinada. Bl2 codifica uma proteina de $223 \mathrm{kDa}$ contendo um domínio de 173 aminoácidos repetido 3 vezes ao longo da proteína e intercalado por blocos contendo um número variável de repetiçōes seriadas de 20 aminoácidos. A estrutura de B 12 é peculiar, uma vez que em outros antigenos de $T$. cruzi clonados as repetições seriadas estão contidas em um único bloco. Uma busca no banco de dados GenBank demonstrou homologia com proteinas ricas em prolina, incluindo a subunidade pesada da proteína triplet de neurofilamento (NF-H) de mamíferos. 
Um terceiro gene, denominado B 1 , e que hibridiza com um transcrito de $5.5 \mathrm{~kb}$, foi localizado a cerca de $9,5 \mathrm{~kb}$ a montante de B12. Análises de Southern blot, feitas a partir de DNA de T. cruzi digerido com enzimas de restriçăo ou de cromossomos, demonstrou que B11 apresenta mùltiplas cópias dispersas no genoma do parasita. A seqüência nucleonidica de um fragmento de $0,7 \mathrm{~kb}$ de $\mathrm{B} 1 \mathrm{l}$ revelou homologia, a nivel protéico, com o produto de TRS-1, um elemento semelhante a retrotransposon, isolado de $T$. brucei (Murphy et al.: J. Mol, Biol, 195: 855-871, 1987). 


\section{SUMMARY}

Characterization of two contiguous antigen genes of Trypanosoma cruzi presenting immunodominant repetitive epitopes

A genomic library of $T$. cruzi in the vector $\lambda g t l l$ was screened with antitrypomastigote serum. Two clones, named $\mathrm{B} 12$ and $\mathrm{B} 13$, were isolated and shown to express proteins which contain tandemly repeated units of 20 amino acids (B12) and 12 amino acids (B13). Inserts from clones BI2 and B13 were subcloned in the vector pMSgt l 1 and expressed as $\beta$-galactosidase fusion proteins. The characterization of $T$. cruzi antigens coded by recombinants $\mathrm{B} 12$ and 813 was performed by Western blot, using either rabbit antisera to the fusion proteins or immunoselected antibodies from chagasic parienrs. It was concluded that Bl 2 corresponds to antigens of $230 \mathrm{kDa}$ and $200 \mathrm{kDa}$ found, respectively, both in trypomastigotes and epimastigotes, whereas B13 corresponds to polypeptides of $140 \mathrm{kDa}$ and $116 \mathrm{kDa}$ expressed in both evolutive stages. Immunoprecipitation of radioiodinated parasites indicates that the $140 \mathrm{kDa}$ antigen is located on the surface of trypomastigotes, whereas the orher polypeptides correspond to internal antigens. $B 12$ and Bl 3 recombinant proteins were evaluated by radioimmunoassay in the serological diagnosis of Chagas' disease. Analysis of 128 sera from 20 normal individuals, 70 chagasic patients and 38 patients with other parasitoses indicated kappa indexes of 0.94 and 0.61 , respectively, for the $\mathrm{B} L 2$ and $\mathrm{B} 13$ proreins. These data indicate that B 13 polypeptide is a potential candidate for the diagnosis of Chagas' disease.

The inserts of B12 and Bl3 were used to isolate genomic clones from a AEMBL3 library. The restriction map of a region of $32 \mathrm{~kb}$ from $T$. cruzi genome indicated that $\mathrm{B} 12$ and $\mathrm{B} 13$ genes are contiguous. Northem blots showed that B12 corresponds to 7.2 and 8.8 kb mRNAs, whereas B 13 hybridizes to transcripts of 3.5 and $4.2 \mathrm{~kb}$. Southerm blot analysis of rotal digested $T$. cruzi DNA and pulse field-separated chromosomes lead to the conclusion that B12 and B 3 correspond to single copy genes. The entire sequence of a gene homologous to Bl3 was previously reported (Buschiazzo et al: Mol. Biochem. Parasitol., 54: 125-128, 1992), indicaning that ca. 75 units of the 36 bp repeat motif are organized in a single cluster. The complete sequence of $\mathrm{B} 12$ gene and the intergenic region between $\mathrm{Bl} 2$ and B 13 genes were determined. B 12 encodes a $223 \mathrm{kDa}$ protein bearing a 173 amino acids motif repeated 3 times along the sequence and intercalated by clusters containing a variable number of tandemly repeated 20 amino acids units. The sequence of B12 gene is peculiar since in other cloned antigen genes of $T$. cruzi the repeat units are generally located in a single cluster. A search for homology, with the BLAST program, revealed some homology to proline-rich proteins, like mammalian heavy neurofilament subunit (NF-H). 
A third gene, denominated $\mathrm{Bl} l$ and hybridizing to a $5.5 \mathrm{mRNA}$ species, was identified $9.5 \mathrm{~kb}$ upstream from the $5^{\prime}$ end of B 12 gene. Southem blots oi digested DNA and pulse field-separated chromosomes hybridized with the Bll probe, indicating that $\mathrm{Bl} I$ is a multicopy gene distributed in many chromosomes. The nucleotide sequence of a $0.7 \mathrm{~kb}$ fragment from Bll was determined and a search in GenBank database, performed with BLAST program, revealed a significant homology at the protein level to the product of TRS-1 element, a retrotransposon-like sequence of T. brucei (Murphy et al: J. Mol. Biol., 195: $855-871)$. 


\section{REFERÊNCIAS BIBLIOGRÁFICAS}

AFCHAIN, D.; LE RAY, D.; FRUIT, J. \& CAPRON, A. (1979). Antigenic make-up of Trypanosoma cruzi culture formes: identification of a specific component. J. Parasitol., 65: 507-514.

AFFOLTER, M.; RINDISBACHER, L. \& BRAUN, R. (1989). The rubulin gene cluster of Trypanosoma brucei starts with an intact $\beta$-gene and ends with a truncated $\beta$-gene intemupted by a retrotransposon-like sequence. Gene, 80: 177-183.

AFFRANCHINO, J.L.; IBAÑEZ, C.F.; LUQUETTI, A.O.; RASSI, A.; REYES, M.B.; MACINA, R.A.; ASLUND, L.; PETTERSSON, U. \& FRASCH, A.C.C. (1989). Identification of a Trypanosoma cruzi antigen that is shed during the acute phase of Chagas disease. Mol. Biochem. Parasitol., 34: 221-228.

AKSOY, S. (1991). Site-specific retrotransposons of the trypanosomatid protozoa. Parasitol. Today, 7: 281-285.

AKSOY, S. (1993). A family of target site-specific retrotransposons interrupts spliced leader RNA genes in Typanosomarids. J. Parasitol, 79: 645-652.

AKSOY, S.; LALOR, T.M.; MARTIN, J.; VAN DER PLOEG, L.H.T. \& RICHARDS, F.F. (1987). Multiple copies of a retroposon interrupt spliced leader RNA genes in the African trypanosome, Trypanosoma gambiense. EMBO J., 6: 3819-3826.

AKSOY, S.; WLLLAMS, S.; CHANG, S.; RICHARDS, F.F. (1990). SLACS retrotransposon from Trypanosoma brucei gambiense is similar to mammalian LINEs. Nucleic Acids Res., 18: 785-792.

ALBERTS, B.; BRAY, D.; LEWIS, J.; RAFF, M.; ROBERTS, K. \& WATSON, J.D. (1989). Molecular Biology of the Cell. $2^{\mathrm{a}}$ edição, Garland Publishing.

ALMEIDA, E.; KRIEGER, M.A.; CARVALHO, M.R.; OELEMANN, W. \& GOLDENBERG, S. (1990). Use of recombinant antigens for the diagnosis of Chagas' disease. Mem Inst. Oswaldo Cruz, 85: 513-517.

ALONSO, G.; GUEVARA, P. \& RAMIREZ, J.L. (1992). Trypanosomatidae codon usage and GC distribution. Mem. Inst. Oswaldo Cruz, 87: $517-523$. 
ALTSCHUL, S.F.; GISH, W.; MILLER, W; MYYERS, E..W. \& LIPMAN, D.J. (1990). Basic local alignment search tool. J. Mol. Biol., 215, 403-410.

ANDRADE, A.Z. (1991). Pathogenesis of Chagas' disease. Res. Immunol, 142: 126-129.

ANDREWS, N.W.; ALVES, M.J.M.; SCHUMACHER, R.I. \& COLLI, W. (1985). Trypanosoma cruzi: protection in mice immunized with 8-methoxypsoralen inactivated trypomastigotes. Exp. Parasitol., 60: 255-262.

ARRUDA, M.V; REINACH, F.C.; COLLI, W. \& ZINGALES, B. (1990). Sequence of the 24 Sa ribosomal RNA gene and characterization of a corresponding pseudogene from Trypanosoma cruzi. Mol. Biochem. Parasitol., 40: 35-42.

AVILA, H.A.; PEREIRA, J.B; THIEMANN, O.; DE PAIVA, E.; DEGRAVE, W; MOREL, C. \& SIMPSON, L. (1993). Detection of Trypanosoma cruzi in blood specimens of chronic chagasic patients by polymerase chain reaction amplification of kinetoplast minicircle DNA: comparison with serology and xenodiagnosis. J. Clin. Microbiol., 31 : 2421 -2426.

AVILA, H.A.; SIGMAN, D.S.; COHEN, L.M.; MILIKAN, R.C. \& SIMPSON, L. (1991). Polymerase chain reaction amplification of Trypanosoma cruzı kinetoplast minicircle DNA isolated from whole blood lysates: diagnosis of chronic Chagas' disease. Mol. Biochem. Parasitol., 48: $211-222$.

AYMERICH, S. \& GOLDENBERG, S. (1989). The karyotype of Trypanosoma cruzi Dm 28c: comparison with other T. cruzi strains and trypanosomatids. Exp. Parasitol, 69: 107115.

BASSO, B.; MORETTI, E.R.A. \& VOTTERO-CIMA, E. (199l). Immune response and Trypanosoma cruzi infection in Trypanasama rangeli-immunized mice. Am J. Trop. Med. Hyg., 44: 413-419.

BEARD, C.A.; WRIGHTSMAN, R.A. \& MANNING, J.E. (1988). Stage and strain specifíc expression of the tandemly repeated $90 \mathrm{kDa}$ surface antigen gene family in Trypanosoma cruzi. Mol. Biochem. Parasitol, 28: 227-234.

BENNE, R. (1990). RNA editing in trypanosomes: is there a message? Trends Genet., 6: 177181 . 
BENNE, R.; VAN DEN BURG, J.; BRAKENHOFF, J.P.J; SLOOF, P.; VAN BOOM, J.H. \& TROMP, M.C. (1986). Major transcript of the frameshifted coxll gene from trypanosome mitochondria contains four nucleotides that are not encoded in the DNA. Cell, 46: 819826.

BIGGIN, M.D.; GIBSON, T.J. \& HONG, G.F. (1983). Buffer gradient and ${ }^{35}$ S label as an aid to rapid DNA sequence determination. Proc. Natl. Acad. Sci. USA, 80: 3963-3965.

BLUM. B.; BAKALARA, N. \& SIMPSON, L. (1990). A model for RNA editing in kinetoplastid mitochondria: "guide" RNA molecules transcribed from maxicircle DNA provide the edited information. Cell, 60: 189-198.

BLUM, B.; STURM, N.R.; SIMPSON, A.M. \& SIMPSON, L. (1991). Chimeric gRNA-mRNA molecules with oligo(U) tails covalently linked at sites of RNA editing suggest that $U$ addition occurs by transesterification. Cell, 65 : 543-550.

BOEKE, J.D. \& CORCES, V.G. (1989). Transcription and reverse transcription of retrotransposons. Annu. Rev. Microbiol., 43: 403-434.

BONTEMPI, E.J.; BÚA, J.; ASLUND, L.; PORCEL, B.; SEGURA, E.L.; HENRIKSSON, J.; ÖRN, A.; PETTERSSON, U. \& RUIZ, A.M. (1993). Isolation and characterization of a gene from Trypanosoma cruzi encoding a 46-kilodalton protein with homology to human and rat tyrosine aminotransferase. Mol. Biochem. Parasitol., 59: 253-262.

BOOTHROYD, J.C. \& CROSS, G.A.M. (1982). Transcripts coding for variant surface glycoproteins of Trypanosoma brucei have a short, identical exon at their 5 ' end. Gene, 20: $281-289$.

BORST, P. (1991). Why kirecoplast DNA networks? Trends Genet., 7: 139-141.

BOUCHÉ, J.P. (1981). The effect of spermidine on endonuclease inhibition by agarose contaminants. Anal. Biochem., 125: 42-45.

BRAUN, R.; BEHRENS, K.; GLAUSER, A. \& BRUN, R. (1992). Evolution of the retrotransposons TRS/ingi and of the tubulin genes in trypanosomes. Acta Trop., 52: 175-187.

BRENER, Z. (1973). Biology of Trypanosoma cruzi. Annu. Rev. Microbiol., 27: 347-383. 
RRENER, Z. (1980). Immunity to Trypanosoma cruzi. Adv. Parasitol, 18: 247-292.

BRENER, Z. (1986). Why vaccines do not work in Chagas disease. Parasirol. Today, 2: 196197.

BRENER, Z. (1987). Parhogenesis and immunoparhology of chronic Chagas' disease. Mem. Inst. Oswaldo Cruz (Suppl), 82: 205-213.

BRENER, 2. \& CAMARGO, E.P. (1982). Perspectives of vaccination in Chagas disease. Pontif. Acad. Sci. Scr. Varia, 47: 145-168.

BRENER, Z. \& CHIARI, E. (1963). Variaçòes morfológicas observadas em diferentes amostras de Trypanosoma cruzi. Rev. Inst. Med. Trop. São Paulo, 5: 220-224.

RROWN, W.C.; ZHAO, S.; WOODS, V.M.; TRIPP, C.A.; TETZLAFF, C.L; HEUSSLER, V.T.; DOBBELAERE, D.A.E. \& RICE-FICHT, A.C. (1993). Identification of two Thl cell epitopes on the Babesia bovis-encoded 77-kilodalton merozoite protein (Bb-1) by use of truncated recombinant fusion proteins. Infect. Immun., 61:236-244.

BURNETTE, W.N. (1981). "Western Blotting": electrophoretic transfer of proteins from sodium dodecyl sulphate-polyacrylamide gels to unmodified nitrocellulose and radiographic detection with antibody and radioiodinated protein $\mathrm{A}$. Anal Biochem., 112: 195-203.

BURNS, J.M., JR.; SHREFFLER, W.G.; ROSMAN, D.E.; SLEATH, P.R.; MARCH, C.J. \& REED, S.G. (1992). Identification and synthesis of a major conserved antigenic epitope of Trypanosoma cruzi. Proc. Natl. Acad. Sci. USA, 89: 1239-1243.

BUSCHIAZZO, A.; CAMPETEJLA, O.E; MACINA, R.A.; SALCEDA, S.; FRASCH, A.C.C. \& SANCHEZ, D.O.. (1992). Sequence of the gene for a Trypanosoma cruzi protein antigenic during the chronic phase of human Chagas disease. Mol. Biochem. Parasitol. 54:125-128.

CAMARGO, M.E. (1966). Fluorescent antibody test for the serodiagnosis of american rrypanosomiasis. Technical modification employing preserved culture forms of Trypanosoma cruzi in a slide test. Rev. Inst. Med. Trop. São Paulo, 5: 227-234. 
CAMARGO, M.E; HOSHINO, S. \& SIQUEIRA, G.R.V. (1973). Hemagglutination with preserved, sensitized cells, a practical test for routine serologic diagnosis of american Trypanosomiasis. Rev. Inst. Med. Trop. São Paulo, 15: 81-85.

CAMAARGO, M.E; HOSHINO-ShIMIZU, S.; MACEDO, V.; PERES, B.A. \& CASTRO, C. (1977). Diagnóstico sorológico da infecçāo humana pelo Trypanosoma cruzi. Estudo comparativo de testes de fixação do complemento, imunofluorescência, hemaglutinação e floculaçāo, em 3.624 soros. Rev. Inst. Med. Trop. São Paulo, 19: 254-260.

CAMARGO, M.E. \& REBONATO, C. (1969). Cross-reactivity in fluorescence tests for Trypanosoma and Leishmania antibodies. Am. J. Trop. Med. Hyg., 18: 500-505.

CAMPBELL, D.A.; THORNTON, D.A. \& BOOTHROYD, J.C. (1984). Apparent discontinuous transcription of Trypanosoma brucei variant surface antigen genes. Nature, 311: 350355.

CAMPETELLA, O.E.; HENRIKSSON, J. ASLUND, L. FRASCH, A.C.C.; PETTERSSON, U. \& CAZZULO, J.J. (1992). Tha major cysteine proteinase (cruzipain) from Trypanosoma cruzi is encoded by multiple polymorphic tandemly organized genes located on different chromosomes. Mol, Biochem. Parasitol, 50: 225-234.

CAMPETELLA, O.E.; UTTARO, A.D.; PARODI, A.J. \& FRASCH, A.C.C. (1994). A recombinant Trypanosoma cruzi trans-sialidase lacking the amino acid repeats retains the enzymatic activity. Mol. Biochem. Parasitol., 64: 337-340.

CANO, M.I.; SANTORI, F.R.; ARAYA, J.E.; SANTOS, M.R;; RAMIREZ, I.M.; GALINDO, I.; GUEVARA, P.; RAMIREZ, J.L; SOLARI, A.; MORTARA, R.A. \& FRANCO DA SILVEIRA, J. (1994). Chromosome polymorphism in Trypanosoma cruzi and selection of chromosome-specific markers. Mem. Inst. Oswaldo Cruz (Suppl.), 89: 118.

CARRINGTON, M.; RODITI, I. \& WILIAMS, R.O. (1987). The structure and transcription of an element interspersed between tandem array of mini-exon donor genes in Trypanosoma brucei. Nucleic Acids. Res., 15: 10179-10198.

CASTELLANI, O.; RIBEIRO, L. V. \& FERNANDES, J. F. (1967). Differentiation of Trypanosoma cruzi in culture. J. Protozool., 14: 447-451. 
CASTRO, C.; CRAIG, S.P. \& CASTAÑEDA, M. (1981). Genome organization and ploidy number in Trypanosoma cruzi. Mol. Biochem. Parasitol., 4: 273-282.

CAVENER, D.R. \& RAY, S.C. (1991). Eukaryotic start and stop translation sites. Nucleic Acids. Res., 19: 3185-3192.

CAZZULO, J.J.; COUSO, R.; RAIMONDI, A.; WERNSTEDT, C. \& HELLMAN, U. (1989). Further characterization and partial amino acid sequence of a cysteine proteinase from Trypanosoma cruzi. Mal. Biochem. Parasitol, 33: 33-42.

CAZZULO, J.J. \& FRASCH, A.C.C. (1992). SAPA/trans-sialidase and cruzipain: two antigens from Trypanosoma cruzi contain immunodominant but enzymatically inmactive domains. FASEB J., 6: 3259-3264.

CHIARI, E. (1992). Diagnostic rests for Chagas disease. Em Wendel, S.; Brener, Z.; Camargo, M.E. \& Rassi, A. (editores) Chagas disease (American Trypanosomiasis): its Impact on Transfusion and Clinical Medicine. ISBT Brazjl'92, São Paulo, Brasil, pág. 153-164.

CHIARI, E. \& BRENER, Z. (1966). Contribuição ao diagnóstico parasitológico da doença de Chagas na sua fase crônica. Rev. Inst. Med. Trop. São Paulo, 8: 134-138.

CHILDS, G.; MAXSON, R.; COHN, R.H. \& KEDES, L. (1981). Orphons: dispersed generic elements derived from tandem repetitive genes of eucaryotes. Cell, 23: 651-663.

CHIN, S.S.M. \& LIEM, R.K.H. (1990). Transfected rat high-molecular-weight neurofilament (NF-H) coassembles with vimentin in a predominantly nonphosphorylated form. $J$. Neurosci., 10: 3714-3726.

CHOU, P.Y. \& FASMAN, G.D. (1978). Prediction of the secondary structure of proteins from their amino acid sequence. Methods Enzymol, 47: 45-148.

CHU, G.; VOLLRATH, D \& DAVIS, R.W. (1986). Separation of large DNA molecules by contour-clamped homogeneous electric fields. Science, 234: 1582-1585.

CLAYTON, C.E. (1988). The molecular biology of the Kinetoplastidae. Em Rigby, P.W.J, (editor) Genetic Engineering. Vol. 7. San Diego, CA, Academic Press Inc. 
COHEN, J. (1960). A coefficient of agreement for nominal scales. Educ. Phsycol. Meas., 20: $37-46$.

COLLI.W.; ANDREWS, N.W. \& ZINGALES, B. (1981). Surface determinants in American Trypanosomes. Em: Schweiger, H.G. (editor) International Cell Biology 1980/1981. Springer, Berlin Heidelberg New York, pág. 418-441.

CONTRERAS, V.T.; SALLES, J.M.; THOMAS, N.; MOREL, C.M. \& GOLDENGERG, S. (1985). In vitro differentiation of Trypanosoma cruzi under chemically defined conditions. Mol. Biochem. Parasitol., 16: 315-327.

COTRIM, P.C.; PARANHOS, G.S.; MORTARA, R.A.; WANDERLEI, J.; RASSI, A.; CAMARGO, M.E. \& FRANCO DA SILVEIRA, J. (1990). Expression in Escherichia coli of a dominant immunogen of Trypanosoma cruzi recognized by human chagasic sera. J. Clin. Microbial., 28: 519-524.

CROSS, G.A.M. (1990). Glycolipid anchoring of plasma membrane protcins. Annu. Rev. Cell. Biol., 6: 1-39.

CRUZ, A.K.; TITUS, R. \& BEVERLEY, S.M. (1993). Plasticity in chromosome number and resting of essential genes in Leishmania by targeting. Proc. Natl. Acad. Sci. USA, 90: $1599 \cdot 1603$.

CUNHA-NETO, E. (1994). Imunopatogênese da cardiopatia chagásica humana: estudo dos linfócitos infiutrantes da lesão e da reaçāo cruzada miosina cardíaca-Trypanosoma cruzi. Tese (Doutorado) - Instituto de Ciências Biomédicas da Universidade de São Paulo Depro. de Imunologia. São Paulo.

CUNHA-NETO, E.; DURANTI, M.; GRUBER, A.; ZINGALES, B.; DE MESSIAS, I.; STOLF, N.; BELLOTTI, F.; PATARROYO, M.E.; PILLEGGI, F. \& KALIL, J. (1994). Autoimmunity in Chagas' disease cardiopathy: biological relevance of a cardiac myosin-specific epitope crossreactive to an immunodominant Trypanosoma cruzi antigen. Proc. Natl. Acad. Sci. USA (no prelo).

DAVIS, L.G.; DIBNER, M.D. \& BATTEY, J.F. (1986). Basic Methods in Molecular Biology. Elsevier Science Publishing Co. Inc., New York.

DAYHOFF, M.O.; BARKER, W.C. \& HUNT, L.T. (1983). Establishing homologies in protein sequences. Methods Enzymol., 91: 524-545. 
DEGRAVE, W.; FRAGOSO, S.P;; BRITTO, C.; VAN HEUVERSWYN, H.; KIDANE, G.Z.; CARDOSO, M.A.B.; MUELLER, R.U.; SIMPSON, L. \& MOREL, C.M. (1988). Peculiar sequence organization of kinetoplast DNA minicircles from Trypanosoma cruzi. Mol. Biochem. Parasitol., 27: 63-70.

DE LAFAille, M.A.C.; LABAN, A. \& WTRTH, D.F. (1992). Gene expression in Leishmania: analysis of essential S' DNA sequences. Proc. Natl. Acad. Sci. USA, 89: 2703-2707.

DE LANGE, T; LIU, A.Y.C.; VAN DER PLOEG, L.H.T.; BORST, P.; TROMP, M.C. \& VAN BOOM, J.H. (1983). Tandem repetition of the 5' mini-exon of variant surface glycoprotein genes: a multiple promoter for VSG gene transcription? Cell, 34: 891-900.

DE LANGE, $\Upsilon$; BERKVENS, T.M.; VEERMAN, H.J.G.; FRASCH, A.C.C.; BARRY, J.D. \& BORST, P. (1984a). Comparison of the genes coding for the common 5 terminal sequence of messenger RNAs in three trypanosome species. Nucleic Acids Res., 12: 4431-4443.

DE LANGE, T.; MICHELS, P.A.M.; VEERMAN, H.J.G.; CORNELISSEN, A.W.C.A. \& BORST, P. (1984b). Many trypanosome messenger RNAs share a common 5' terminal sequence. Nucleic Acids Res., 12: 3777-3790.

DEVEREUX, J.; HAEBERLI, P. \& SMITHIES, O. (1984). A comprehensive ser of sequence analysis programs for the VAX. Nucleic Acids Res., I2: 387-395.

DLAS, J.C.P. (1987). Control of Chagas disease in Brazil. Parasitol. Today, 3: 336-341.

DLAZ, C; NUSSENZWEIG, V. \& GONZALEZ, A. (1992). An improved polymerase chain reaction assay to detect Trypanosoma cruzi in blood. Am. J. Trop. Med. Hyg., 46: 616-623.

DI GIOVANI, L.; COCHRANE, A.H. \& ENEA, V. (1990). On the evolutionary history of the circumsporozoite protein in plasmodia. Exp. Parasitol., 70: 373-381.

DRAGON, E.A.; BROTHERS, V.M.; WRIGHTSMAN. R.A. \& MANNING, J. (1985). A M 90000 surface polypeptide of Trypanosoma cruzi is a candidate for a Chagas' disease diagnostic antigen. Mol, Biochem. Parasitol., 16: 213-229. 
EAKIN, A.E; MILLS, A.A.; HARTH, G.; McKERROW, J.H. \& CRAIK, C.S. (1992). The sequence, organization, and expression of the major cysteine proteinase (cruzain) from Trypanosoma cruzi. J. Biol. Chem., 267: 7411-7420.

ENGLUND, P.T.; HAJDUK, S.L. \& MARINI, J.C. (1982). The molecular biology of trypanosomes. Annu. Rev. Biochem., 51: 595-726.

ENGMAN, D.M.; REDDY, L.V.; DONELSON, J.E. \& KIRCHHOFF, L.V. (1987). Trypanosoma cruzi exhibits inter- and intra-strain heterogeneity in molecular karyotype and chromosomal gene location. Mol. Biochem. Parasitol., 22: 115-123.

FANNING, T.G. \& SINGER, M.F. (1987). LINE-1: a mammalian transposable element. Biochim. Biophys. Acta, 910: 203-212.

FAWCETT, T.W. \& BARTLETT, S.G. (1990). An effective method for eliminating "artifact banding" when sequencing double-stranded DNA templates. Biotechniques, 9: 46-48.

FEAGIN, J.E.; ABRAHAM, J.M. \& STUART, K. (1988). Extensive editing of the cytochrome $c$ oxidase III transcript in Trypanosoma brucei. Cell., 53: 413-422.

FERREIRA, A.W. (1992). Tests for Chagas' disease serodiagnosis: a review. Em Wendel, S.; Brener, Z.; Camargo, M.E. \& Rassi, A. (editores) Chagas disease (American Trypanosomiasis): its Impact on Transfusion and Clinical Medicine. ISBT Brazil'92, São Paulo, Brasil.

FERREIRA, A.W; BELEM, Z.R.; MOURA, M.E.G. \& CAMARGO, M.E. (1991). Aspectos da padronizaçāo de testes sorológicos para a doença de Chagas: um teste imunoenzimático para a triagem de doadores de sangue. Rev. Inst. Med. Trop. São Paulo, 33: 123-128.

EERGUSON, M.A.J. \& WILLLAMS, A.F. (1988). Cell-surface anchoring of proteins via glycosylphosphatidylinositol structures. Annu. Rev. Biochem., 57: 285-320.

FRANCO DA SILVEIRA, J.; PARANHOS, G.S.; COTRIM, P.C.; MORTARA, R.A.; CALLARGO, M.E.; RASSI, A.; WANDERLEY, J.; CORRAL, R.; FREILIJ, H.L.; GRINSTEIN, S. \& DEGRAVE, W. (1990). Antigens of Trypanosoma cruzi with clinical interest cloned and expressed in Escherichia coli. Mem. Inst. Oswaldo Cruz, 85: 507-51l. 
FRASCH, A.C.C.; CAZZURO, J.J.; ASLUND, L. \& PETTERSSON, U. (1991). Comparison of genes encoding Trypanosoma cruzi antigens. Parasital. Today, 7: 148-151.

FRASCH, A.C.C. \& REYES, M.B. (1990). Diagnosis of Chagas disease using recombinant DNA technology. Parasitol. Today, 6: 137-139.

FREISTADT, M.S.; CROSS, G.A.M.; BRANCH, A.D. \& ROBERTSON, H.D. (1987). Direct analysis of the mini-exon donor RNA of Trypanosama brucei: detection of a novel cap structure also present in messenger RNA. Nucleic Acids Res., 23: 9861-9879.

FRISCHAUF, A.-M.; LEKRACH, H.; POUTSKA, A. \& MURRAY, N. (1983). Lambda replacement vectors carrying polylinker sequences. J. Mol. Biol., 170: 827-842.

FRISCHAUF, A.-M.; MURRAY, N. \& LEHRACH, H. (1987). $\lambda$ phage vectors - EMBL series. Methods Enzymol., 153: 103-115.

FUCHS, R. \& BLAKESLEY, R. (1983). Guide of the use of type II restriction endonucleases. Methods Enzymol., 100: 3-38.

GABRIEL, A. \& BOEKE, J.D. (1991). Reverse transcriptase encoded by a retrotransposon from the trypanosomatid Crithidia fasciculata. Proc. Natl. Acad. Sci. USA., 88: 9794-9798.

GABRIEL, A.; YEN, T.J.; SCHWARTZ, D.C.; SMITH, C.L.; BOEKE, J.D.; SOLLNER-WEBB, B. \& CLEVELAND, D.W. (1990). A rapidly rearranging retrotransposon within the miniexon gene locus of Crithidia fasciculata. Mol. Cell. Biol, 10: 615-624.

GAZZINELLI, R.T.; GALVÃO, L.M.C.; KRAUTZ, G.; LIMLA, A.P.C.A; CANÇADO, J-R.; SCHARFSTEIN, J. \& KRETTLI, A.U. (1993). Use of Trypanosoma cruzi purified glycoprotein (GP57/51) or trypomastigote-shed antigens to assess cure for human Chagas' disease. Am. J. Trop. Med. Hyg., 49:625-635.

GEYSEN, H.M.; RODDA, S.J.; MASON, T.J.; TRIBBICK, G. \& SCHOOFS, P.G. (1987). Strategies for epitope analysis using peptide sunthesis. J. Immunol. Methods, 102: 259-274.

GIBSON, W.C. \& MILES, M.A. (1986). The karyorype and ploidy of Trypanosoma cruzi. EMBO. J., 5: 1299-1305. 
GIBSON, W.C.; OSINGA, K.A.; MYCHELS, P.A.M. \& BORST, P. (1985). Trypanosomes of subgenus Trypanozoon are diploid for housekeeping genes. Mol. Biochem. Parasitol, 16: 231-242.

GLAUSER, A. \& BRAUN, R. (1994). TUBIS, a fossilized retroposon in the tubulin gene cluster of Trypanosoma brucei. Biochim. Biophys. Acta, 1218: 99-101.

GONZÁLEZ, A.; LERNER, T.J.; HUECAS, M.; SOSA-PINEDA, B.; NOGUEIRA, N. \& LIZARDI, P.M. (1985). Apparent generation of a segmented mRNA from two separate tandem gene families in Trypanosoma cruzi. Nucleic Acids Res., 13: 5789-5804.

GONZȦLEZ, A.; PREDIGER, E;; HUECAS, M.E.; NOGUEIRA, N. \& LIZARDI, P. (1984). Minichromosomal repetitive DNA in Trypanosoma cruzi: its use in a high-sensitivity parasite detection assay. Proc. Natl. Acad. Sci. USA, 81: 3356-3360.

GONZÁLEZ, A.; ROSALES, J.L.; LEY, V. \& DIAZ, C. (1990). Cloning and characterization of a gene coding for a protcin (KAP) associated with the kinetoplast of epimastigores and amastigotes of Trypanosoma cruzi. Mol. Biochem. Parasitol, 40: 233-244.

GOODE, B. L. \& FEINSTEIN, S. C. (1992). "Speedprep" purification of template for doublestranded DNA sequencing. BioTechniques, 12: 374-375.

GRIECO, F; HAY, J.M. \& HULL, R. (1992). An improved procedure for the purification of protein fused with glutathione $S$-transferase. Biotechniques, 13: 856-857.

GRUBER, A. \& ZINGALES, A. (1993). Trypanosama cruzi characterization of two recombinant antigens with potential application in the diagnosis of Chagas' disease. Exp. Parasitol., 76: 1-12.

GUHL, F.; HUDSON, L.; MARINKEILE, C.J.; MORGAN, S.J. \& JARAMILLO, C. (1985). Antibody response to experimental Trypanosoma rangelf infection and its implications for immunodiagnosis of South American trypanosomiasis. Acta Trop., 42: $311-318$.

GUHL, F.; HUDSON, L.; MARINKELLE, C.J; JARAMIILLO, C.A. \& BRIDGE, D. (1987). Clinical Trypanosoma rangeli infection as a complication of Chagas' disease. Parasitology, 94: $475-484$. 
HANAHAN, D. (1985). Techniques for transformation of E. coli. Em Glover, D.M. (editor) DNA Cloning: a practical approach. Oxford, IRL Press. Vol. 1, pág. 109-135.

HARTREE, E.F. (1972). Determination of protein: a modification of the Lowry method that gives a linear photometric response. Anal. Biochem., 48: 422-427.

HASAN, G.; TURNER, M.J. \& CORDINGLEY, J.S. (1984). Complete nucleotide sequence of an unusual mobile element from Trypanosoma brucei. Cell, 37: 333-341.

HE, M.; WILDE, A. \& KADERBHAI, M.A. (1990). A simple single-step procedure for small scale ргерaration of Escherichia coli plasmids. Nucleic Acids Res., 18: 1660.

HELFMAN, D.M.; FERAMISCO, J.R.; FIDDES, J.C.; THOMAS, G.P. \& HUGHES, S.H. (1983). Identification of clones that encode chicken tropomyosin by direct immunological screening of a cDNA expression library. Proc. Natl. Acad. Sci. USA, 80: 31-35.

HENIKOFF, S. (1987). Unidirectional digestion with exonuclease III in DNA sequence analysis. Methods Enzymol., 155: 156-165.

HENRIKSSON, J.; ASLUND, L.; MACINA, R.A.; FRANKE DE CAZZULO, B.M.; CAZZULO, J.J.; FRASCH, A.C.C. \& PETTERSSON, U. (1990). Chromosomal localization of seven cioned antigen genes provides evidence of diploidy and further demonstration of karyorype variability in Trypanosoma cruzi. Mol. Biochem. Parasitol., 42: $213-224$.

HIGGINS, D.G. \& SHARP, P.M. (1988). Clustal: a package for performing multiple sequence alignment on a microcomputer. Gene, 73: 237-244.

HIGGINS, D.G.; BLEASBY, A.J. \& FUCHS, R. (1991) CLUSTAL V: improved software for multiple sequence alignment. Comput. Appl. Biosci., 8: 189-191.

HOARE, C.A. \& WALLACE, F.G. (1966). Developmental stages of trypanosomatid flagellates: a new terminology. Nature, 212: 1385-1386.

HOFT, D.F.; KIM, K.S.; OTSU, K.; MOSER, D.R.; JOHN YOST, W.; BLUMIN, J.H.; DONELSON, J.E. \& KIRCHOFF, L.V. (1989). Trypanosoma cruzi expresses diverse repetitive protein antigens. Infect. Immun., 57: 1959-1967.

HOHN, B. (1979). In vitro packaging of $\lambda$ and cosmid DNA. Methods Enzymol.., 68: 299-309. 
HOHN, B. \& MURRAY, K. (1977). Packaging recombinant DNA molecules into bacteriophage particles in vitro. Proc. Natl. Acad. Sci. USA, 74: 3259-3263.

HUANG, J. \& VAN DER PLOEG, L.H.T. (I991). Requirement of a polypyrimidine tract for trans-splicing in trypanosomes: discriminating the PARP promoter from the imediarely adjacent $3^{\prime}$ splice acceptor site. EMBO J., 10: 3877-3885.

HUDSON, L.; GUHL, F.; DE SANCHEZ, N.; BRIDGE, D.; JARAMILLO, C.A. \& YOUNG، A. (1988). Longitudinal studies of the immune response of Colombian patients infected with Trypanosoma cruzi and T. rangeli. Parasitology, 96: $449-460$.

IBAN̄EZ, C.F; AFFRANCHINO \& FRASCH, A.C.C. (1987). Antigenic determinants of Trypanosoma cruzi defined by cloning of parasite DNA. Mol. Biochem. Parasitol., 25: 175-184.

IBAÑEZ, C.F; AFFRANCHINO, J.L.; MEDINA, R.A.; REYES, M.B.; LEGUIZ.AMON, S.; CAMARGO, M.E.; ASLUND, L.; PETTERSSON, U. \& FRASCH, A.C.C. (1988). Multiple Trypanosoma cruzi antigens containing randemly repeated aminoacid sequence motifs. Mol. Biochem. Parasitol., 30: 27-34.

IMBODEN, M.A.; LAIRD, P.W.; AFFOLTER, M. \& SEEBECK, T. (1987). Transcription of the intergenic regions of the tubulin gene cluster of Trypanosoma brucei: evidence for a polycistronic ranscription unit in a eukaryote. Nucleic Acids Res., 15: 7357-7368.

JULIEN, J.-P.; CÔTÉ, F; BEAUDET, L.; SIDKY, M.; FLAVELL, D.; GROSVELD, F. \& MUSHYNSKI, W. (1988). Sequence and structure of the mouse gene coding for the largest neurofilament subunit. Gene, 68: 307-314.

KABSCH, W. \& SANDER, C. (1983). How good are predictions of protein secondary structure? FEBS Lett., 155: 179-182.

KAHN, S.; COLBERT, T.G.; WALLACE, J.C.; HOAGLAND, N.A. \& EISEN, H. (1991). The major 85-kDa surface antigen of the mammalian-stage forms of Trypanosoma cruzi is a family of sialidases. Proc. Natl. Acad. Sci. USA, 88: 4481-4485.

KARN, J.; BRENNER, S.; BARNETT, L. \& CESARENL, G. (1980). Novel bacteriophage $\lambda$ cloning vector. Proc. Natl. Acad. Sci. USA, 77: 5172-5176. 
KENDALL, G.; WILDERSPIN, A.F.; ASHALL, F.; MILES, M.A. \& KELLY, J.M. (1990). Trypanosoma cruzi glycosomal glyceraldehyde-3-phosphate dehydrogenase does not conform to the 'hotspot' topogenic signal model. EMBO J., 9: 2751-2758.

KESSLER, S.W. (1975). Rapid isolation of antigens from cells with a staphylococcal protein Aantibody adsorbent: parameters of the interaction of antibody-antigen complexes with protein A. J. Immunol., 115: 1617-1624.

KIMMEL, B.E.; OLE-MOTYOI, O.K. \& YOUNG, J.R. (1987). Ingi, a 5.2-kb dispersed sequence element from Trypanosoma brucei that carries half of a smaller mobile element at either end and has homology with mammalian LINEs. Mol. Cell. Biol., 7: 146j-1475.

KLINKERT, M.Q.; RUPPEL, A.; FELLEISEN, R.; LINK, G. \& BECK, E. (1988). Expression of diagnostic $31 / 32$ kílodalton proteins of Schistosoma mansoni as fusions with bacteriophage MS2 polymerase. Mol. Biochem. Parasitol., 27: 233-240.

KLUG, A. \& RHODES, D. (1987). 'Zinc fingers': a novel protein motif for nucleic acid recognition. Trends Biochem. Sci, 12: 464-469.

KOOTER, J.M. \& BORST, P. (1984). $\alpha$-amanitin-insensitive transcription of variant surface glycoprotein genes provides further evidence for discontinuous transcription in trypanosomes. Nucleic Acids Res., 12: 9457-9472.

KOOY, R.F.; ASHALL, F.; VAN DER PLOEG, M. \& OVERDULVER, J.P. (1989). On the DNA content of Trypanosoma cruzi. Mol. Biochem. Parasital., 36: 73-76.

KOZAK, M. (1984). Compilation and analysis of sequences upstream from the translational start site in eukaryotic mRNAs. Nucleic Acids Res., 12: 857-872.

KOZAK, M. (1989). The scanning model for translation: an update. J. Cell Biol, 108: 229-241.

KRETTL, A.U. \& BRENER, Z. (1982). Resistance against Trypanosoma cruzi associated to anti-living trypomastigote antibodies. J. Immunol., 128: 2009-2012.

KRETTLI, A.U.; CANÇADO, J.-R. \& BRENER, Z. (1982). Effect of specific chemotherapy on the levels of lytic antibodies in Chagas' disease. Trans. R. Soc. Trop. Med. Hyg., 76: 334-340. 
KRIEGER, M.A.; ALMEIDA, E.; OELEMANN, W.; LAFAILlE, J.J., PEREIRA, J.B.; KRIEGER, H.; CARVALHO, M.R. \& GOLDENBERG, S. (1992). Use of recombinant antigens for the accurate immunodiagnosis of Chagas' disease. Am J. Trop. Med. Hyg., 46: $+27-434$.

KRIEGER, M.A.; SALLES, J.M.; ALMEIDA, E; LINSS, J.; BONALDO, M.C. \& GOLDENBERG, S. (1990). Expression and polymorphism of a Trypanosoma cruzi gene encoding a cytoplasmic reperitive antigen. Exp. Parasitol., 70: 247-254.

KYTE, J. \& DOOLITTLE, R.F. (1982). A simple method for displaying the hydropathic character of a protein. J. Mol. Biol., 157: 105-132.

LAEMMLI, U.K. (1970). Cleavage of structural proteins during the assembly of the head of bacteriophage $\Upsilon 4$. Nature, 227: 680-685.

LAFAJLLE, J.J.; LINSS, J.; KRIEGER, M.A.; SOUTO-PADRÓN, T.; DE SOUZA, W. \& GOLDENBERG, S. (1989). Structure and expression of two Trypanosoma cruzi genes encoding antigenic proteins bearing repetitive epitopes. Mol. Biochem. Parasitol, 35: 127-136.

LAIRD, P.W.; KOOTER, J.M.; LOOSBROEK, N. \& BORST, P. (1985). Mature mRNAS of Trypanosama brucei possess a $5^{\prime}$ cap acquired by discontinuous RNA synthesis. Nucleic Acids Res. 13: 4253-4266.

LAIRD, P.W.; ZOMERDIJK, J.C.B.M.; DE KORTE, D. \& BORST, P. (1987). In vivo labelling of intermediates in the discontinuous synthesis of mRNAs in Trypanosoma brucei. EMBO J., 6: 1055-1062.

LANAR, D.E.; SILVEN LEVY, L. \& MANNING, J. (1981). Complexity and content of the DNA and RNA in Trypanosoma cruzi. Mol. Biochem. Parasitol, 3: 327-341.

LASKEY, R.A. \& MILLS, A.D. (1977). Enhanced autoradiographic detection of ${ }^{32} \mathrm{P}$ and ${ }^{125} 1$ using intensifying screens and hypersensitized film. FEBS Lett., 82: 314-316.

LAYDEN, R.E. \& EISEN, H. (1988). Alternate trans splicing in Trypanosoma equiperdum: implications for splice site selection. Mol. Cell. Biol, 8: 1352-1360.

LEBOWITZ, J.H.; SMITH, H.Q; RUSCHE, L. \& BEVERLEY, S.M. (1993). Coupling of poly (A) site selection and trans-splicing in Leishmania. Genes \& Dev. 7: 996-1007. 
LEES, J.F.; SCHNEIDMAN, P.S; SKUNTZ, S.F.; CARDEN, M.J. \& LAZZARINI, R.A. (1988). The structure and organization of the human heavy neurofilament subunit $(N F \cdot H)$ and the gene encoding it. EMBO J., 7: 1947-1955.

LEGUIZAMON, M.S.; CAMPETELLA, O.E;; REYES, M.B.; IBAÑEZ, C.F.; BASOMBRIO, M.A.; RINCON, J.; ÖRN, A. \& FRASCH, A.C.C. (1991). Bloodstream Trypanosoma cruzi parasites from mice simultaneously express antigens that are markers of acute and chronic human Chagas disease. Parasitology, 102: 379-385.

LENARDO, M.J.; DORFMAN, D.M. \& DONEISON, J.E. (1985). The spliced leader sequence of Trypanosoma brucei has a potential role as cap donor structure. Mol. Cell. Biol., 9: 2487 2490.

LEVIN, M.J.; CANO, M.l.; FRANCO DA SILVEIRA, J:; DEGRAVE, W.; RONDINELLI, E.; ZINGALES, B.; SOLARI, A.; REQUENA, J.M.; ALONSO, C; GONZÁLEZ, A., HERNÁNDEZ, R.; RAMIREZ, J.L; LE PASLIER, D. \& SAUMIER, M. (1994). Trypanosoma cruzi genome project: analysis of the molecular karyotype of clone CL Brener. Mem. Inst. Oswaldo Cruz (Suppl.), 89: 116.

LEVIN, M.J.; MESRI, E.; BENAROUS, R.; LEVITUS, G.; SCHIJMAN, A.; LEVY-Y'EYATI, P.; CHLALE. P.A.; RUIZ, A.M.; KAHN, A.; ROSENBAUM, M.B.; TORRES, H.N. \& SEGURA, E. (1989). Identification of major Trypanosoma cruzi antigenic determinants in chronic Chagas' heart disease. Am. J. Trop. Med. Hyg., 41: 530-538.

LEVIN, M.J.; ROSSI, R.; LEVITUS, G.; MESRI, E.; BONNEFOY, S.; KERNER, N. \& HONTEBEYRIEJOSKOWICZ, M. (1990). The cloned C-terminal region of a Trypanosoma cruzi $P$ ribosomal protein harbors two antigenic determinants. immunol. Lett., 24: 69-74.

LEVIN, M.3.; VAZQUEZ, M.; KAPLAN, D. \& SCHIJMAN, A.G. (1993). The Trypanosama cruzi ribosomal P protein family: classification and antigenicity. Parasitol. Today, 9: 38 l-384.

LEWIN, B. (1994). Genes V. New York, NY, Oxford University Press Inc.

LOCKETT, T.J. (1990). A bacteriophage $\lambda$ DNA purification procedure suitable for the analysis of DNA from either large or multiple small lysares. Anal. Biochem., 185: 230234. 
LODES, M.J.; SMILEY, B.L.; STADNYK, A.W.; BENNET, J.L.; MYLER, P.j. \& STUART, K. (1993). Expression of a retroposon-like sequence upstream of the putative Trypanosoma brucei variant surface glycoprotein gene expression site promoter. Mol. Cell. Biol., 13: 7036 7044.

LOWRY, O.H.; ROSEBROUGH, N.J.; FARR, A.L. \& RANDALL, R.J. (195 1). Protein measurement with the Folin phenol reagent. J. Biol. Chem., 193: 265-275.

LUQUETTI, A.O. (1990). Use of Trypanosoma cruzi defined proteins for diagnosis Multicentre trial - Serological and technical aspects. Mem. Inst. Oswaldo Cruz, 85: 497 505.

MACINA, R.A.; AFFRANCHINO, J.L.; POLLEVICK, G.D.; JAZIN, E.E. \& FRASCH, A.C.C. (1989). Variable number of repeats in genes encoding Trypanosoma cruzi antigens. FEBS Letters, 257: $365-368$.

MARKWELL, M.A.K. \& FOX, C.F. (1978). Surface-specific iodination of membrane proteins of viruses and cucaryoric cells using 1,3,4,6-tetracloro-3 $\alpha, 6 \alpha$-diphenylglycoluril. Biochemistry, 17: 4807-4817.

MARSTON, F.A.O. (1986). Review Article. The purification of cucaryotic polypeprides synthesized in Escherichia coli. Biochem. J., 240: 1-12.

MARSTON, F.A.O. (1987). The purification of eucaryotic polypeptides expressed in Escherichia coli. Em Glover, D.M. (editor) DNA cloning: a practical approach. Oxford, IRL Press. Vol. 3, pág. 59-87.

MATTHEWS, K.R.; TSCHUDI, C. \& ULLU, E. (1994). A common pyrimidine-rich motif governs trans-splicing and polyadenylation of rubulin polycistronic pre-mRNA in trypanosomes. Genes \& Dev., 8: $491-501$.

MCCARTHY-BURKE, C; TAYLOR, Z.A. \& BUCK, G.A. (1989). Characterization of the spliced leader genes and transcripts in Trypanosoma cruzi. Gene, 82: 177-189.

MELO, R.C. \& BRENER, Z. (1978). Tissue tropism of different Trypanosoma cruzi strains. J. Parasitol., 64: 475-482. 
MESSING, J. \& VIEIRA, J. (1982). A new pair of M13 vectors for selecting either DNA strand of double-digest restriction fragments. Gene, 19: 269-276.

MIERENDORF, R.C. \& PFEFFER, D. (1987). Direct sequencing of denatured plasmid DNA. Methods Enzymol., 152: 556-562.

MILES, M.A. \& CIBULSKIS, R.E. (1986). The heterogeneity of Trypanosoma cruzi - Zymodeme characterization of Trypanosoma cruzj. Parasitol. Today, 2: 94-101.

MILHAUSEN, M.; NELSON, R.G.; SATHER, S.; SELKIRK, M. \& AGABIAN, N. (1984). Identification of a small RNA containing the trypanosome spliced leader: a donor of shared 5' sequences of trypanosomatid mRNAs? Cell, 38: $721-729$.

MONCADA, C.; REPETTO, Y.; ALDUNATE, J.; LETELIER, M.E. \& MORELLO, A. (1989). Role of glutathione in the suscetibility of Trypanosoma cruzi to drugs. Comp. Biochem. Physiol., 94: 87.91 .

MONCAYO, A. \& LUQUETTI, A.O. (1990). Multicentre double blind study for evaluation of Trypanosoma cruzi defined antigens as diagnostic reagents. Mem. Inst. Oswaldo Cruz, 85: 489-495.

MOREL, C.M.; DEANE, M.P. \& GONÇALVES, A.M. (1986). The heterogeneity of Trypanosoma cruzi - The complexiry of Trypanosoma cruzi populations revealed by schizodeme analysis. Parasitol. Today, 2: 94-101.

MORELLO, A. (1988). Review. The biochemistry of the mode of action of drugs and the detoxication mechanisms in Trypanosoma cruzi. Comp. Biochem. Physiol., 90C: 1-12.

MOSER, D.R; KIRCHHOFF, L.V.\& DONELSON, J.E. (1989). Detection of Trypanosoma cruzi by DNA amplification using the polymerase chain reaction. J. Clin. Microbiol., 27: 14771482.

MUHICH, M.L. \& BOOTHROYD, J.C. (1988). Polycistronic transcripts in trypanosomes and their accumulation during heat shock: evidence for a precursor role in mRNA synthesis. Mol. Cell. Biol., 8: 3837-3846. 
MUHICH, M.L.; HSU, M.P. \& BOOTHROYD, J.C. (1989). Heat-shock disruption of trans-splicing in trypanosomes: effect on Hsp70, Hsp85 and tubulin mRNA synthesis. Gene, 82: 169 175.

MUNIZ, J. \& DE FREITAS, G. (1944). Contribuiçào para o diagnóstico da doença de Chagas pelas reaçōes de imunidade. Mem. Inst. Oswaldo Cruz, 41: 303-333.

MURPHY, W.J.; WATKINS, K.P. \& AGABLAN, N. (1986). Identification of a novel Y branch structure as an intermediate in trypanosome mRNA processing: evidence for trans splicing. Cell, 47: 517-525.

MURPHY, N.B.; PAYS, A.; TEBABI, P.; COQUELET, H.; GUYAUX, M.; STEINERT, M. \& PAYS, E. (1987). Trypanosoma brucei repeated element with unusual structural and transcriptional properties. J. Mol. Biol., 195: 855-871.

MUSTO, H.; RODRÍGUEZ-MASEDA, H. \& BERNARDI, G. (1994). The nuclear genomes of African and American trypanosomes are strikingly different. Gene, 141: 63-69.

NEAL, R.A. \& MILES, R.A. (1970). Indirect haemagglutination test for Chagas' disease, with a simple method for survey work. Rev. Inst. Med. Trop. São Paulo, 12: 325-332.

NELSON, R.G.; PARSONS, M.; BARR, P.J; STUART, K.; SELKIRK, M. \& AGABIAN, N. (1983). Sequences homologous to the variant antigen mRNA spliced leader are located in tandem repeats and variable orphons in Trypanosoma brucei. Cell, 34: 901-909.

NELSON, R.G.; PARSONS, M.; SELKIRK, M.; NEWPORT, G.; BARR, P.j. \& AGABIAN, N. (1984). Sequences homologous to variant antigen mRNA spliced leader in Trypanosomatidae which do not undergo antigenic variation. Nature, 308: 665-667.

ØRSKOV, F. \& ORSKOV, 1. (1984). Serotyping of Escherichia coli. Methods Microbiol, 14: 43112.

OZAKI, L.S; MATTEI, D.; JENDOUBI, M.; DRUIHLE, P.; BLISNICK, T.; GUILLOTE, M. PUIJALON, O. \& PEREIRA DA SILVA, L. (1986). Plaque antibody selection: rapid immunological analysis of a large number of recombinant phage clones positive to sera against Plasmodium falciparum antigens. J. Immunol. Methods, 89: 213-219. 
PAN, A.A.; ROSENBERG, G.B.; HURLEY, M.K.; SCHOCK, G.J.H.; CHU, V.P. \& ATYAPPA, A. (1992). Clinical evaluation of an EIA for the sensitive and specific derecrion of serum antibody to Trypanosoma cruzi (Chagas' disease). J. Infect. Dis., 165: 585-588.

PARANHOS, G.S.; COTRIM, P.C.; MORTARA, R.A.; RASSI, A.; CORRAL, R.; FREILU, H.L.; GRINSTEIN, S.; WANDERLEY, J:; CAMARGO, M.E. \& FRANCO DA SILVEIRA, J. (1990). Trypanosoma cruzi: cloning and expression of an antigen recognized by acute and chronic human chagasic sera. Mol. Biochem. Parasilol., 71: 284-293.

PARANHOS-BACALLA, G.S.; SANTOS, M.R.M.; COTRIM, P.C.; RASSI, A.; JOLIVET, M.; CAMARGO, M.E. \& FRANCO DA SILVEIRA, 3. (1994). Detection of antibodies in sera from Chagas' disease patients using a Trypanosoma cruzi immunodominant recombinant antigen. Parasite Immunol., 16: 165-169.

PARODI, A.J.; POLLEVICK, G.D.; MAUTNER, M.; BUSCHIAZZO, A.; SANCHEZ, D.O. \& FRASCH, A.C.C. (1992). Identification of the gene(s) coding for the trans-sialidase of Trypanosoma cruzi. EMBO J., 11: 1705-1710.

PARSONS, M.; NELSON, R.G.; WATKINS, K.P. \& AGABLAN, N. (1984). Trypanosome mRNAs share a common 5' spliced leader sequence. Cell, 38: 309-316.

PARSONS, M.; STUART, K. \& SMILEY, B.L. (1991). Trypanosoma brucei: analysis of codon usage and nucleotide composition of nuclear genes. Exp. Parasitol., 73: 101-105.

PAYS, E. \& MURPHY, N.B. (1987). DNA-binding fingers encoded by a rypanosome retroposon. J. Mol. Biol, 197: 147-148.

PEARSON, W.R. \& LIPMAN, D.J. (1988). Improved tools for biological sequence companson. Proc. Natl. Acad. Sci. USA, 85: 2444-2448.

PERALTA, J.M.; TELXEIRA, M.G.M.; SHREFFLER, W.G.; PEREIRA, J.B.; BURNS, J.M., JR.; SLEATH, P.R. \& REED, S.G. (1994). Serodiagnosis of Chagas' disease by enzyme-linked immunosorbent assay using two synthetic peptides as antigens. J. Clin. Microbiol., 32: 971-974. 
PEREIRA, M.E.A.; MEJIA, J.S.; ORTEGA-BARRIA, E.; MATZILEVICH, D. \& PRIOLI, R.P. (I991). The Trypanosoma cruzi neuraminidase contains sequences similar to bacterial neuraminidases, YWTD repats of the low density lipoprotein receptor, and rype III modules of fibronectin. J. Exp. Med., 174: 179-191.

PETERSON, D.S.; WRIGHTSMAN, R.A. \& MANNING, J.E. (1986). Cloning of a major surfaceantigen gene of Trypanosoma cruzi and identification of a nonapeptide repeat. Nature, 322: 566-568.

PLUMAS-MARTY, B.; VERWAERDE, C; LOYENS, M.; VELGE, P.; TAIBI, A.; CESBRON, M. -F.; CAPRON, A. \& OUAISSI, M.A. (1992). Typanosoma cruzi glutathione-binding proteins: immunogenicity during human and experimental Chagas' disease. Parasitology, 104: 87. 98.

POLLEVICK, G.D.; AFFRANCHINO, J.L.; FRASCH, A.C.C. \& SANCHEZ, D.O. (1991). The complete sequence of a shed-acure phase antigen of Trypanosoma cruzi. Mol. Biochem. Parasitol., 47: 247-250.

POLLEVICK, G.D;; SANCHEZ, D.O.; CAMPETELLA, O.; TROMBETTA, S.; SOUSA, M.; HENRIKSSON, J.; HELLMAN, U.; PETTERSSON, U.; CAZZULO, J.J. \& FRASCH, A.C.C. (1993). Members of the SAPA/rans-sialidase protein family have identical $N$-terminal sequences and a putative signal peptide. Mol. Biochem. Parasitol., 59: 171-174.

PROUDFOOT, N. (199l). Poly(A) signals. Cell, 64:67 l-674.

RALPH, D.; HUANG, J. \& VAN DER PLOEG, L.H.T. (1988). Physical identification of branched intron side-products of splicing in Trypanosma brucei. EMBO J., $7: 2539-254.5$.

RASSI, A.; LUQUETTI, A.O.; RASSI JUNIOR, A.; RASSI, S.G. \& RASSI, A.G. (1992). Chagas disease - Clinical features. Em Wendel, S.; Brener, Z.; Camargo, M.E. \& Rassi, A. (editores) Chagas disease (American Trypanosomiasis); its Impact on Transfusion and Clinical Medicine. ISBT Brazil'92, São Paulo, Brasil, pág. 81·101.

REQUENA, J.M.; JIMENEZ-RUIZ, A.; SOTO, M.; LOPEZ, M.C. \& ALONSO, C. (1992). Characterization of a highly repeated interspersed DNA sequence of Trypanosoma cruzi: its porential use in diagnosis and strain classification. Mol. Biochem. Parasitol, 51: 271 280. 
REQUENA, J.M.; MARTÍN, F.; SOTO, M.; LÓPEZ, M.C. \& ALONSO, C. (1994). Characterization of a short interspersed reiterated DNA sequence of Trypanosoma cruzi located at the 3'end of a poly $(A)^{+}$transcript. Gene, 146: 245-250.

REVELARD, P.; LIPS, S. \& PAYS, E. (1993). Alternative splicing within and between alleles of the ATPase gene 1 locus of Trypanosoma brucei. Mol. Biochem. Parasitol., 62: 93-102.

REYES, M.B.; LORCA, M.; MUÑOZ, P. \& FRASCH, A.C.C. (1990). Fetal IgG specificities against Trypanosoma cruzi antigens in infected newborns. Proc. Natl. Acad. Sci. USA, 87: 28462850.

ROMLANHA, A.J.; PEREIRA, A.A.S.; CHIARI, E. \& KILGOUR, V. (1979). Isoenzyme pattem of cultured Trypanosoma cruzi: changes after prolonged subculture. Comp. Biochem. Physiol., 62B: 139-142.

RUEF, B.J. \& MANNING, J.E. (1993). Isolation and characterization of the TSA/trans-sialidase family gene from the Silvio strain of Trypanosoma cruzi. Mol. Biochem. Parasitol. 62: $117-120$.

RUSSOMANDO, G.; FIGUEREDO, A.; ALMIRÓN, M.; SAKAMOTO, M. \& MORITA, K. (1992). Polymerase chain reaction-based detection of Trypanosoma cruzi DNA in serum. J. Clin. Microbiol, 30: 2864-2868.

SAMBROOK, J.; FRITSCH, E.F. \& MANIATIS, T. (1989). Molecular Cloning - A Laboratory Manual. $2^{\mathrm{a}}$ ediçāo. Cold Spring Harbor, NY, Cold Spring Harbor Laboratory Press.

SANGER, F.; NICKLEN, S. \& COULSON, A.R. (1977). DNA sequencing with chain terminating inhibitors. Proc. Natl. Acad. Sci. USA, 74: 5463-5467.

SARASTE, M.; SIBBALD, P.R.; WITTINGHOFER, A. (1990). The P-loop - a common motif in ATP- and GTP-binding proteins. Trends Biochem. Sci, 15: 430-434.

SCHARFSTEIN, J.; SCHECHTER, M.; SENNA, M.; PERALTA, J.M.; MENDONÇA-PREVIATO, L. \& MILES, M.A. (1986). Trypanosoma cruzi: characterization and isolation of $57 / 51,000$ m.w. surface glycoprotein (GP57/51) expressed in epimastigotes and bloodstream trypomastigotes. J. Immunol., 137: 1836-1842. 
SCHERF, A.; MATTEI, D. \& SCHREIBER, M. (1990). Parasite antigens expressed in Escherichia coli. A refined approach for epidemiological analysis. J. Immunol Methods, 128: 81-87.

SCHOFIELD, C.J. (1985). Control of Chagas' disease. Br. Med. Bull, 41: $187-194$.

SCHOFIELD, L. (1991). On the function of reperitive domains in protein antigens of Plasmodium and other eukaryotic parasites. Parasitol. Today, 7: 99-105.

SCHÖNECK, R.; PLUMAS-MARTY, B.; TAIBI, A.; BILIAUT-MULOT, O.; LOYENS, M.; GRASMASSE, H; CAPRON, A. \& OUAISSI, A. (1994). Trypanosoma cruzi cDNA encodes a tandemly repeated domain strucutre charateristic of small stress proteins and glutathione S-transferases. Biol. Cell., 80: 1- 10.

SCHULER, G.D.; ALTSCHUL, S.F. \& LIPMAN, D.J. (1991). A workbench for multiple alignment construction and analysis. Proteins: Struct. Funct. Genet, 9: 180-190.

SCHÜRCH, N.; HEHL, A.; VASSELLA, E.; BRAUN, R. \& RODITI, I. (1994). Accurate polyadenylation of procyclin mRNAs in Trypanosoma brucei is determined by pyrimidine-rich elements in the intergenic regions. Mol. Cell. Biol., 14: 3668-3675.

SHAW, J.M.; FEAGIN, J.E; STUART, K. \& SIMPSON, L. (1988). Editing of Kinetoplastid mitochondrial mRNAs by uridine addition and deletion generates conserved amino acid sequences and AUG initiation codons. Cell, 53: 401-411.

SHIKANAJ-YASUDA, M.A.; MARCONDES, C.B.; GUEDES, L.A.; SIQUEIRA, G.S.; BARONE, A.A.; DLAS, J.C.P.; AMATO NETO, V.; TOLEZANO, J.E.; PERES, B.A.; ARRUDA JR., E.R.; LOPES, M.H.; SHIROMA, M. \& CHAPADEIRO, E. (1991). Possible oral transmission of acute Chagas' disease in Brazil. Rev. Inst. Med. Trop. São Paulo. 33: 351- 357.

SHORT, J.M.; FERNANDEZ, J.M.; SORGE, J.A. \& HUSE, W.D. (1988). $\lambda$ ZAP: a bacteriophage $\lambda$ expression vector with in vivo excision properties. Nucleic Acids Res., 16: 7583-7600.

SILVA, L.H.P. \& NUSSENZWEIG, V. (1953). Sobre uma cepa de Trypanosoma cruzi altamente virulenta para o camundongo branco. Folia Clin. Biol., 20: 191-207.

SIMONS, P.C. \& VANDER JAGT, D.L. (1977). Purification of glutathione S-transferase from human liver by glutathione-affinity chromatography. Anal. Biochem., 82: 334-341. 
SIMPSON, L. (1987). The mithocondrial genome of kinetoplastid protozoa: genomic organization, trasncription, replication and evolution. Annu. Rev. Microbiol., 41: 363382.

SINGER, M.F. (1982). SINEs and LINEs: highly repeated short and long interspersed sequences in mammalian genomes. Cell, 28: 433-434.

SINGER, M.F. \& SKOWRONSKI, J. (1985). Making sense out of LINES: long interspersed repeat sequences in mammalian genomes. Trends Biochem. Sci., 10: 119-122.

SKEIKY, Y.A.W.; BENSON, D.R.; GUDERIAN, J.A.; SLEATH, P.R.; PARSONS, M. \& REED, S.G. (1993). Trypanosoma cruzi acidic ribosomal P protein gene family - novel P proteins encoding unusual cross-reactive epitopes. J. Immunol., 15 I: 5504-5515.

SMILEY, B.L.; ALINE, R.F., JR.; MYLER, P.J. \& STUART, K. (1990). A retroposon in the 5' flank of a Trypanosoma brucei VSG gene lacks insertional terminal repears. Mol. Biochem. Parasitol. 42: $1+3-152$.

SMITH, D.B. \& JOHNSON, K.S. (1988). Single-step purification of polypeptides expressed in Escherichia coli as fusions with glutathione S-transferase. Gene, 67: 31-40.

SNYDER, M.; ELLEDGE, S.; SWEETSTER, D.; YOUNG, R.A. \& DAVIS, R.W. (1987). agt Il: gene isolation with antibody probes and other applications. Methods Enzymol., 154: 107-128.

SOARES, C.M.A.; CARVALHO, E.F.; URMÉNYI, T.P.; CARVALHO, J.F.O.; CASTRO, F.T. \& RONDINELLI، E. (1989). $\alpha$ - and $\beta$-rubulin mRNAs of Trypanosoma cruzi originate from a single multicistronic transcript. FEBS Lett., 250: 497-502.

SOUTHERN, E.M. (1975). Detection of specific sequences among DNA fragments separated by gel electrophoresis. J. Mol. Biol., 98: 503.517.

SOUTO, R.P. \& ZINGALES, B. (1993). Sensitive detection and strain classification of Trypanosoma cruzi by amplification of a ribosomal RNA sequence. Mol. Biochem. Parasitol., 62: 45-52.

SOUZA, S.L. \& CAMARGO, M.E. (1966). The use of filter paper blood smears in a practical fluorescent test for american trypanosomiasis serodiagnosis. Rev. Inst. Med. Trop. São Paulo, 8: 255-258. 
STEERS, E., JR.; CUATRECASAS, P. \& POLLARD, H.B. (1971). The purification of $\beta$ galactosidase from Escherichia coli by affinity chromatography. J. Biol. Chem., 246: 196200.

STUART, K. (1983). Kinetoplast DNA, mitochondrial DNA with a difference. Mol. Biochem. Parasicol., 9: 93-104.

STURM, N.R.; DEGRAVE, W; MOREL, C. \& SIMPSON, L. (1989). Sensitive detection and schizodeme classification of Trypanosoma cruzi cells by amplification of kinetoplast minicircle DNA sequences: use in diagnosis of Chagas' disease. Mol. Biochem. Parasitol., 33: $205-214$.

STURM, N.R. \& SIMPSON, L. ( (990a). Partially edited mRNAs for cytochrome b and subunit III of cytochrome oxidase from Leishmania carentolae mitochondria: RNA editing intermediates. Cell, 61:871-878.

STURM, N.R. \& SIMPSON, L. (1990b). Kinetoplast DNA minicircles encode guide RNAs for editing of cytochrome oxidase subunit IIl mRNA. Cell, 61: 879-884.

SUTTON, R.E. \& BOOTHROYD, J.C. (1986). Evidence for trans splicing in trypanosomes. Cell, 47: 527.535 .

SWANSTROM, R. \& SHANK, P.R. (1978). X-ray intensifying screens greatly enhance the detection by autoradiography of the radioactive isotopes ${ }^{32} \mathrm{P}$ and ${ }^{125} \mathrm{I}$. Anal Biochem., 86: 184-192.

TACKLE, G.B. \& CROSS, G.A.M. (1991). An 85-kilodalton surface antigen gene family of Trypanosoma cruzi encodes polypeptides homologous to bacterial neuraminidases. Mol. Biochem. Parasitol., 48: 185-198.

TACKLE, G.B.; YOUNG, A.; SNARY, D.; HUDSON, L. \& NICHOLLS, S.C. (1989). Cloning and expression of a trypomastigote-specific 85-kilodalton surface antigen gene from Trypanosoma cruzi. Mol. Biochem. Parasitol., 37: 57-64.

TANOWITZ, H.B.; KIRCHHOFF, L.V.; SIMON, D.; MORRIS, S.A.; WEISS, L.M. \& WITTNER, M. (1992). Chagas' disease. Clin. Microbiol, Rev., 5: 400-419. 
TEIXFIRA, A.R.L.; CORDOVA, J.C.; SOUTO MLAIOR, I. \& SOLORZANO, E. (1990a). Chagas's disease: lymphoma growth in rabbits treated with benznidazole. Am. J. Trop. Med. Hyg., 43: 146-158.

TEIXEIRA, A.R.L.; SILVA, R.; CUNHA NETO, E.; SANTANA, J.M. \& RIZZO, L.V. (I990b). Malignant, non-Hodgkin's lymphomas in Trypanosoma cruzi-infected rabbits treated with nitroarenes. J. Comp. Pathol., 103: 37-48.

TOWBIN, H.; STAEHELIN, T. \& GORDON, J. (1979). Electrophoretic transfer of proteins from polyacrylamide gels to nitrocelulose sheets: procedure and some applications. Proc. Natl. Acad. Sci. USA, 76: $4350-4354$.

TRIPATHI, R. L. (1992). Altemative dideoxy sequencing of double-stranded DNA. Biotechniques, 12: 390-391.

TIBAYRENC, M. \& AYALA, F.J. (1987). Trypanosoma cruzi populations: more clonal than sexual. Parasitol. Today, 3: 189-190.

TIBAYRENC, M. \& AYALA, F.J. (1988). (sozyme variability in Trypanosoma cruzi, the agent of Chagas' disease: genetical, taxonomical and epidemiological significance. Evolution, 42: $277-292$.

TIBAYRENC, M.; KJELLBERG, F. \& AYALA, F.J. (1990). A clonal theory of parasitic protozoa: the population structures of Entamoeba, Giardia, Leishmania, Naegleria, Plasmadium, Trichomonas, and Trypanosoma and their medical and taxonomical consequences. Proc. Natl. Acad. Sci. USA, 87: 2414-2418.

TIBAYRENC, M.; WARD, P.; MOYA, A. \& AYALA, F.J. (1986). Natural populations of Trypanosoma cruzi, the agent of Chagas disease, have a multiclonal structure. Proc. Natl. Acad. Sci. USA, 83: 115-119.

UEMURA, H.; SCHENKMAN, S.; NUSSENZWEIG, V. \& EICHINGER, D. (1992). Only some members of a gene family in Trypanosoma cnuzi encode proteins that express both trans-sialidase and neuraminidase activities. EMBO J., 11: 3837-3844.

UMEZAWA, E.S.; SHIKANAI-YASUDA, M.A.; GRUBER, A; PEREIRA.CHIOCCOLA, V.L. \& ZINGALES, B. (1994). Chagas' disease: reactivity of acute phase antibodies to defined antigens of Trypanosoma cruzi. Manuscrito em preparação. 
UMEZAWA, E.S; STOLF, A.M.S. \& ZINGALES, B. (1993). Trypanosoma cruzi: different surface antigens of trypomastigotes are targets of lytic antibodies. Acta Trop, 54:41-53.

VAITUKAITIS, J.L. (1981). Production of antisera with small doses of immunogen: multiple intradermal injections. Methods Enzymol., 73: 47.52.

VAN DER PLOEG, L.H.T.; LIU, A.Y.C.; MICHELS, P.A.M.; DE LANGE, T.; BORST, P.; MAJUMDER, H.K.; WEBER, H.; VEENEMAN, G.H. \& VAN BOOM, J. (1982). RNA splicing is required to make the messenger RNA for a variant surface antigen in mypanosomes. Nucleic Acids Res., 12: 3591-3604.

VAN VOORHIS, W.C; BARRET, L.; KOELLING, R. \& FARR, A.G. (1993). FL-160 proteins of Trypanosoma cruzi are expressed from a multigene family and contain two distinct epitopes that mimic nervous tissues. J. Exp. Med., 178: 681-694.

VAN VOORHIS, W.C. \& EISEN, H. (1989). Fl-160: a surface antigen of Trypanosoma cruzi that mimics mammalian nervous tissue. J. Exp. Med., 169: 641-652.

VAN VOORHIS, W.C; SCHLEKEWY, L. \& TRONG, H.L. (199l). Molecular mimicry by Trypanosoma cruzi: the Fl-160 epitope that mimics mammalian nerve can be mapped to a 12-amino acid peptide. Proc. Natl. Acad. Sci. USA, 88: 5993-5997.

VERGARA, U.; LORCA, M.; VELOSO, C.; GONZALEZ, A.; ENGSTROM, A.; ASLUND, L; PETTERSSON, U. \& FRASCH, A.C.C. (1991). Assay for detection of Trypanosoma cruzi antibodies in human sera based on reaction with synthetic peptides. J. Clin. Microbiol., 29: $2034-2037$.

VERGARA, U.; VELOSO, C.; GONZALEZ, A. \& LORCA, M. (1992). Evaluation of an enzymelinked immunosorbent assay for the diagnosis of Chagas' disease using synthetic peptides. Am. J. Trop. Med. Hyg., 46: 39-43.

VICKERMAN, K. (1985). Developmental cycles and biology of pathogenic trypanosomes. Br. Med. Bull., 41: 105-114.

VCKERMAN; K. (1986). Clandestine sex in trypanosomes. Nature, 322: 113-114. 
VILLANUEVA, M.S; WILLIAMS, S.P.; BEARD, C.B.; RICHARDS, F.F. \& AKSOY, S. (1991). A new member of a family of site-specific retrotransposons is present in the spliced leader RNA genes of Trypanosoma cruzi. Mol. Cell. Biol., 11: 6139-6148.

VON HEJNE, G. (1985). Signal sequences: the limirs of variation. J. Mol. Biol, 184: 99-105.

VON HEIJNE, G. (1986). A new method for predicting signal sequence cleavage sites. Nucleic Acids Res., 14: 4683.4690 .

WADA, K.; WADA, Y.; ISHIBASHI, F; GOJOBORI, T. \& IKEMURA, T. (1992). Codon usage tabulated from the GenBank genetic sequence data. Nucleic Acids Res. (suppl.)., 20: $2111-2118$.

IVALDER, J.A.; EDER, P.S.; ENGMAN, D.M.; BRENTANO, S.T.; WALDER, R.Y.; KNUTZON, D.S.; DORFMAN, D.M. \& DONELSON, J.E. (1986). The 35-nucleotide spliced leader sequence is common to all trypanosome messenger RNA's. Science, 233: 569-571.

WALKER, J.E.; SARASTE, M.; RUNSWICK, M.J.; GAY, N.J. (1982). Distantly related sequences in the $\alpha$ - and $\beta$-subunits of ATP symthase, myosin, kinases and other ATP-requiring enzymes and a common nucleotide binding fold. EMBO J., 1: 945-951.

WANG, B. \& SODJA, A. (1991). Alternate approach to sequencing double-stranded template DNAs. BioTechniques, 10: 198-201.

WENDEL, S. \& BRENER, Z. (1992). Historical aspects. Em Wendel, S.; Brener, Z.; Camargo, M.E. \& Rassi, A. (editores) Chagas disease (American Trypanosomiasis): its Impact on Transfusion and Clinical Medicine. ISBT Brazil'92, São Paulo, Brasil, pág. 5-12.

WINCKER, P.; BRITTO, C.; PEREIRA, J.B.; CARDOSO, M.A.; OELEMANN, W. \& MOREL, C.M. (1994). Use of simplified polymerase chain reacrion procedure to derect Trypanosoma cruzi in blood samples from chronic chagasic patients in a rural endemic area. Am. J. Trop. Med. Hyg. (no prelo).

WINCKER, P.; ROIZES, G. \& GOLDENBERG、 S. (1990). Characterization of a Trypanosoma cruzi specific nuclear repeated sequence. Mol. Biochem. Parasitol., 41: 147-152.

XIONG, Y. \& EICKBUSH, T.H. (1990). Origin and evolution of retroelements based upon their reverse transcriptase sequences. EMBO J., 9: 3353-3362. 
YANISH-PERRON, C; VIEIRA, J. \& MESSING, J. (1985). Improved M13 phage cloning vectors and host strains; nucleotide sequences of the $M 13 \mathrm{mpl} 8$ and pUC19 vectors. Gene, 33 : 103-119.

YAWETZ, A. \& AGOSIN, M. (1981). Purification of the glutathione S-transferase of Trypanosoma cruzi. Comp. Biochem. Physiol., 68B: 237-243.

YOSHIDA, N. (1983). Surface antigens of metacyclic trypomastigotes of Trypanosoma cruzi. Infect. Immun., 40: 836-839.

IOUNG, R.A. \& DAVIS, R.W. (1983a). Efficient isolation of genes by using antibody probes. Proc. Natl. Acad. Sci. USA, 80: 1194-1198.

YOUNG, R.A. \& DAVIS, R.W. (1983b). Yeasr RNA polymerase ll genes: isolation with antibody probes. Science, 222: 778-782.

ZINGALES, B.; ANDREWS, N.W.; KUWAJIMA, V.Y. \& COLLI, W. (1982). Cell surface antigens of Trypanosoma cruzi: possible correlation with the interiorization process in mammalian cells. Mol. Biochem. Parasitol., 6: 111-124.

ZINGALES, B. \& COLLI, W. (1985). Trypanosoma cruzi: interaction with host cells. Curr. Top. Microbiol. Immunol, 117: 129-152.

ZINGALES, B.; GRUBER, A.; RAMALHO, C.B.; UMEZAWA, E.S. \& COLLI, W. (1990). Use of two recombinant proteins of Trypanosoma cruzi in the serological diagnosis of Chagas' disease. Mem. Inst. Oswaldo Cruz, 85: 519-522.

ZINGALES, B.; PEREIRA, M.E.S.; ALMEIDA, K.A.; OLIVEIRA, R.P.; GONÇALVES, A.; SOUTO, R.P. \& UMEZAWA, E.S. (1994) Trypanosoma cruzi genome project: biological characteristics and molecular markers of the CL Brener clone. Mem. Inst. Oswaldo Cruz (Suppl.), 89: 115.

ZWIERZYNSKI, T.A.; WIDMER, G. \& BUCK, G.A. (1989). In vitro 3' end processing and poly(A) tailing of RNA in Trypanosoma cruzi. Nucleic Acids Res., 17: 4647-4660. 


\section{CURRICULUM VITAE}

Nome: Arthur Gruber

Local e data de nascimento: Sāo Paulo, 13/03/65

\section{EDUCAÇĀO:}

Colégio Equipe, São Paulo, SP, 1980-1982.

Fac. de Medicina Veterinária e Zootecnia, Universidade de São Paulo, 1983-1987

Médico Veterinário

Instituto de Química, Universidade de São Paulo, 1988-1994

Doutor em Bioquimica

\section{OCUPAÇĀO:}

tuxiliar de ensino, Fac. de Medicina da Fundação $A B C, 1989$ até o presente.

\section{PUBLLCAÇÕES:}

Gruber, A.; Mós, E.N.; Durigon \& Noronha, A.M.B. (1985). Prevalência de Campylobacrer jejuni e C. coli em fezes normais e diarréicas de cães em Sāo Paulo. Rev. Microbiol., 16: $287-289$.

Zingales, B; Gruber, A; Ramalho, C.B.; Umezawa, E.S. \& Colli, W. (1990). Use of two recombinant proteins of Trypanosoma cruzi in the serological diagnosis of Chagas disease. Mem. Inst. Oswaldo Cruz, 85: 519-522.

Gruber, A. \& Zingales, B. (1993). Trypanosoma cruzi: characterization of two recombinant antigens with potential appplication in the diagnosis of Chagas' disease. Exp. Parasitol., 76: 1-12.

Zingales, B.; Golgher, D.B.; Marmorato, P.G.; Souto, R.P \& Gruber, A. (1993). Mrolecular approaches to diagnosis of Chagas' disease: use of defined antigens and a target ribosomal RNA sequence. Biol. Res., 26: 89-100.

Cunha-Neto, E; Duranti, M.; Gruber, A.; Zingales, B.; Messias, I.; Stolf, N.; Bellotti, G.; Patarroyo, M.E.; Pilleggi, F. \& Kalil, J. (1995). Autoimmunity in Chagas' dísease: biological relevance of a cardiac myosin-specific epitope crossreactive to an immunodominant Trypanosoma cruzi antigen. Proc. Natl. Acad. Sci. USA (no prelo). 